\title{
A Bibliography of Terrain Modeling (Geomorphometry), the Quantitative Representation of Topography -Supplement 4.0
}

By RICHARD J. PIKE ${ }^{1}$

Provides over 1600 additions and corrections to the 1993

Bibliography of Geomorphometry and its 1995, 1996,

and 1999 Supplements, with an update

of recent advances

\section{OPEN-FILE REPORT 02-465}

2002 
This report is preliminary and has not been reviewed for conformity with U.S. Geological Survey editorial standards or with the North American Stratigraphic Code. Any use of trade, firm, or product names is for descriptive purposes only and does not imply endorsement by the U.S. Government

\title{
U.S. DEPARTMENT OF THE INTERIOR U.S. GEOLOGICAL SURVEY
}

${ }^{1}$ MENLO PARK, California

\begin{abstract}
This report adds over 1600 annotated references on the numerical characterization of topography, terrain modeling or geomorphometry, to a 1993 literature review and its first three updates. Erroneous references from the four earlier reports are corrected and many citations of historic interest are included; the cumulative archive is at 6000 entries. An introductory essay cites several hundred of the new entries. These are listed under various topic headings or referenced in brief discussions of several other areas of research, including terrain data and new parameters, neoorometry, landslide-hazard mapping, Hack's Law, and early work on the mathematical representation of ridges and drainageways.
\end{abstract}

\section{Introduction}

Terrain modeling, the practice of ground-surface quantification, is an amalgam of Earth science, mathematics, engineering, and computer science. The discipline is known variously as geomorphometry (or simply morphometry), terrain analysis, and quantitative geomorphology. It continues to grow through myriad applications to hydrology, geohazards mapping, tectonics, sea-floor and planetary exploration, and other fields. Dating nominally to the co-founders of academic geography, Alexander von Humboldt $(1808,1817)$ and Carl Ritter $(1826,1828)$, the field was revolutionized late in the 20th Century by the computer manipulation of spatial arrays of terrain heights, or digital elevation models (DEMs), which can quantify and portray ground-surface form over large areas (Maune, 2001). Morphometric procedures are implemented routinely by commercial geographic information systems (GIS) as well as specialized software (Harvey and Eash, 1996; Köthe and others, 1996; ESRI, 1997; Drzewiecki et al., 1999; Dikau and Saurer, 1999; Djokic and Maidment, 2000; Wilson and Gallant, 2000; Breuer, 2001; Guth, 2001; Eastman, 2002). The new Earth Surface edition of the Journal of Geophysical 
Research, specializing in surficial processes, is the latest of many publication venues for terrain modeling.

This is the fourth update of a bibliography and introduction to terrain modeling (Pike, 1993, 1995, 1996, 1999) designed to collect the diverse, scattered literature on surface measurement as a resource for the research community. The use of DEMs in science and technology continues to accelerate and diversify (Pike, 2000a). New work appears so frequently that a sampling must suffice to represent the vast literature. This report adds 1636 entries to the 4374 in the four earlier publications $^{1}$. Forty-eight additional entries correct dead Internet links and other errors found in the prior listings. Chronicling the history of terrain modeling, many entries in this report predate the 1999 supplement. Coverage is representative from about 1800 through early-mid 2002. Papers increasingly are published exclusively or in duplicate on the Internet's World Wide Web; the dates given here for Web addresses (URLs) that lack a print publication indicate a Web site's last update or my last access of it.

The bibliography is arranged alphabetically and thus is not readily summarized. This introduction cites about 500 entries, a third of them grouped under 24 morphometric topics, as a guide to the listing's contents. Continuing the practice of previous bibliographies in the series to provide more information on a few applications (see summary of past topics in Pike, 2000a), this report elaborates further on topographic data, putative new parameters, tectonic geomorphology/neo-orometry, biogeography, ice-cap morphometry, results from the Mars Global DEM, landslide-hazard mapping, terrain modeling as physics, Hack's law, and broad-scale computer visualization. The literature of some of these subjects is large, and none of the summaries is intended to more than introduce the topic and comment on some of the current contributions of terrain modeling. Closing the essay is a discussion of pre-1900 papers that trace the evolution of ridge-line and watercourse quantification by descriptive geometry, as well as comments on some new books and an on-line bulletin board.

\section{Revisions in Format}

\footnotetext{
1 The few text citations not in the main bibliography are listed at the close of this introduction or in 'Corrections' appended to the main bibliography.
} 
With this report the title of the series incorporates Terrain Modeling, in an effort to broaden its readership. According to the Internet-search results illustrated in Table 1, Terrain Modeling (plus Modelling) is 15 times more frequent than geomorphometry. Other alternatives are inapt: Digital Terrain Modeling would exclude pre- or non-computer work (Penck, 1894a, b; Hack and Goodlett, 1960); Terrain Analysis has military and nonquantitative connotations (Graff, 1997; DARPA, 2002); Morphometry is a common practice in biology and paleontology (Cracraft, 1980; MacLeod, 1999); Surface Rendering, Terrain Rendering, and Surface Modeling have

Table 1

Ranking Descriptors of Surface Quantification (as keywords on the World Wide Web)

\section{*Index of Hits}

\section{${ }^{*}$ Search Word(s)}

100 Surface Modeling**

72 Surface Topography

57 Morphometry

53 Terrain Modeling ${ }^{\star *}$

40 Terrain Analysis

24 Surface Rendering

18 Digital Terrain Modeling**

14 Terrain Rendering

11 Topographic(al) Analysis**

6 Surface Metrology

3.5 Geomorphometry

2.4 Digital Elevation Modeling**

2.3 Digital Terrain Analysis

1.6 Quantitative Geomorphology

1.2 Landform Modeling ** 


\subsection{Quantitative Terrain Analysis}

*using the exact-phrase option in the Google search engine, 23 September 2002; Index for each term is number of hits / number of hits $(28,100)$ on 'surface modeling' $\times 100$

**includes the British spellings '... Modelling' and 'Topographical ...'

specialized meanings in computer vision and image analysis (Koenderink and van Doorn, 1993, 1994, 1998; López, 1997; Thompson and others, 1998); and Surface Topography connotes industrial micro- and nanomorphometry (Thomas and others, 1999; Blunt and Stout, 2000; Scott, 2001).

Another change with this report is the annotation of all entries except the 90 or so that were not seen but whose titles, context, or literature citations insure involvement with terrain modeling (for example, Malyavsky and Zharnovsky, 1974; Brown, 1994; Schneider, 2001). Most remarks are brief, were made hastily, and reflect the author's interest or understanding at the time-commonly descriptive parameters, techniques and data. This informal annotation is not to be construed as a summary of an entry's contents or an appraisal of the work reported-which ranges from trivial to profound. Comments tend to lengthen with the age of the publication, most early work requiring historic context to justify its inclusion. To increase the usefulness of the (eventual) consolidated bibliography, entries in the initial 1993 listing and prior updates are being annotated. Comments have been appended to $61 \%$ of the combined 6000 citations, and all entries before 1966 .

\section{Topographic Data}

Data availability and quality persist as areas of concern in terrain modeling. In the U.S. a new master DEM assembled from all 55,000 $1: 24,000-$ and $1: 63,360$-scale topographic maps eliminates the onerous tiling of multiple 7.5' quadrangles and other data preparation (Gesch and others, 2002). This National Elevation Dataset (NED) is a seamless, continually updated, DEM of uniform horizontal datum (NAD83), unit of height (decimal meters), and projection. Horizontal grid resolution is 1" (nominally $30 \mathrm{~m}$ ) for the conterminous U.S., Hawaii, and Puerto Rico and $2 "$ for Alaska. Digital filtering during compilation reduces artifacts in the source DEMs (Oimoen, 2000), seamlessly matches adjacent quadrangles, 
and fills sliver areas of missing data. Because heights for much of the country increasingly are gridded at a spacing of $10 \mathrm{~m}$, a 1/3" (nominally $10 \mathrm{~m}$ ) DEM is in progress. New national DEMs are not unique to the U.S. For example, Carroll and Morse (1996) describe creation of the GEODATA 9" DEM of Australia and Hutchinson and others (2001) its subsequent upgrading, including discussion of the ANUDEM gridding algorithm to improve data accuracy. In a reversal of conventional experience, contours for the recently completed 1:50,000-scale topographic maps of Ireland were extracted from DEMs generated by digital photogrammetry (Cory and McGill, 1999).

All DEMs are in some respect flawed (Coops, 2000). Most of the error in current DEMs originated in the contour maps from which they were derived and thus cannot be reduced through efforts of the user. Mapaccuracy standards vary widely and do not provide a rigorous evaluation. Production standards, moreover, guarantee only a statistical level of quality; locally, accuracy can be low. Contour maps are merely models-of varying fidelity-of topography, just as DEMs are, in turn, imperfect models of the maps (Ollier, 1967). Contour maps never were intended to provide heights of the high density and accuracy increasingly required for terrain modeling. What can be mitigated to some extent by the DEM user is error originating in contour map-to-DEM processing (Duh and Brown, 1999; Holmes and others, 2000; Lane and others, 2000; Lynch, 2002). Most DEMs currently available have been interpolated from contours by sampling designs and computer algorithms that add artifacts and other distortions inherent in the processing (Shortridge, 2001). Various procedures have been applied to repair some of these flaws (Hutchinson and Gallant, 2000; Oimoen, 2000; Hutchinson, 2001; Gesch and others, 2002).

Production methods that bypass map contours as the source of digital heights can improve DEM quality. Two emerging technologies that measure the true ground-surface directly have the potential to reduce some of the current shortcomings in DEM coverage and accuracy (Maune, 2001). Laser altimetry, particularly LiDAR (light distance and ranging), promises DEMs of fine resolution and high accuracy (Ritchie, 1995; DeLoach and Leonard, 2000; Brock and others, 2002), as well as seafloor bathymetry (Sandwell and Smith, 2000). Radar interferometry (InSAR or IfSAR) yields terrain-height accuracies and resolutions comparable with those generated by optical methods (Small, 1998; Gens, 1999; Dowman, 2000; Hanssen, 2001; Smith, 2002). Interferometry also is used to monitor displacements of topography, for example, by subsidence or surface faulting. 
LiDAR's aircraft-mounted lasers record 2000-5000 height measurements per second to a vertical precision of $\pm 15 \mathrm{~cm}$. From these voluminous observations DEMs at a horizontal resolution of about a meter can be prepared for large areas (Hill and others, 2000; Carter and others, 2001). While expensive compared to DEMs compiled photogrammetrically or from digitized contours, LiDAR data are decreasing in cost as techniques of acquisition and processing (notably, filtering out vegetation and manmade structures) improve in efficiency and economies of scale make the data more competitive in the marketplace. LiDAR could become the standard procedure, with digital photogrammetry (Gwinner and others, 2000; Lane and others, 2000; Hancock and Willgoose, 2001), for creating fine-scale DEMs of small areas. For representative applications of LiDAR to terrain modeling see Jansma and others (1999), Cowen and others (2000), and Marks and Bates (2000).

Interferometry, which requires simultaneous or repeated signal acquisitions by synthetic-aperture mapping radar, has delivered a nearglobal DEM at a uniform horizontal resolution of $90 \mathrm{~m}$. Over ten days in February 2000, the Shuttle Radar Topographic Mission (SRTM) system onboard Space Shuttle Endeavour imaged about $80 \%$ of Earth's land surface, creating an immense set of terrain heights. The SRTM carried two radar antennas, one aboard the spacecraft, the other at the end of a 60-m mast extending from it. A 3" (nominally 90-m) DEM compiled from mission results (Farr and Kobrick, 2000; NASA, 2002) is taking its place beside the I-km GTOPO30 DEM (Gesch and Larson, 1998; Gesch and others, 1999) that remains the current standard for elevation coverage worldwide. A global 1" (30-m) DEM also is being extracted from the SRTM but only the United States data will be publicly available.

Advanced methods do not assure DEM quality. InSAR, LiDAR, and other remotely-sensed data all contain errors, some of them severe, that are unique to their technologies (Leberl, 1998; Toutin, 1999; Endreny and others, 2000; Ahmadzadeh and Petrou, 2001; Kervyn, 2001; Nuth and others, 2002). The early SRTM results are a cautionary example. Aside from the fact that $1 / 5$ of Earth's land mass (all at high latitudes) was excluded, relative vertical accuracy of the new data at the $90 \%$ level is expected to average $\pm 10 \mathrm{~m}$, a substantial error at the $90-\mathrm{m}$ grid spacing and potentially serious at $30 \mathrm{~m}$. Also, because the radar did not penetrate dense vegetation, data in such areas describe the tree canopy rather than bare ground-in which case the new DEM probably reproduces the terrain surface no more faithfully than the NED. NASA (2002) alerts users of SRTM data to "... be aware that the digital ... topographic data are unedited and are intended for scientific use and 
evaluation. They are outputs directly from the SRTM interferometric radar processor and, for example, may contain numerous voids (areas without data), water bodies may not appear flat, and coastlines may be illdefined." Currently available, more accurate, DEMs thus are likely to remain the better data for many areas. Slatton and others (2001) have proposed a way to fuse LiDAR with InSAR to get coverage that is at once accurate, dense, and extensive.

\section{New (?) Parameters}

While Wolfgang Pauli's "the surface was invented by the devil!" was lamenting complexities of atomic structure at the surface of a solid, the physicist's exasperation applies equally to terrain modeling. Continuous topography is difficult to express, and many new parameters have been proposed to quantify attributes of terrain that existing measures cannot describe. 'New' terrain measures have included mean elevation (Huber, 1825; Sonklar, 1872) and slope gradient (Tillmann, 1915; Bonniard, 1929), relative relief (relief energy in European and Japanese practice; Scheer, 1933; Tada, 1937), the hypsometric integral (Hurtrez and others, 1999; Luo, 2000), and most recently the fractal dimension-which briefly revived the old philosopher's-stone fallacy that a single 'magic number' might suffice to express surface form (Evans and Cox, 1998).

Two approaches recently developed to describe continuous topography, as distinguished from discrete landforms, are the DEM-based 'terrain fabric' of Guth (1999a, b; 2001) and surface 'openness' of Yokoyama and others $(1999,2002)$. Terrain fabric characterizes the tendency of a surface to be organized into linear ridges rather than isotropic topography, whereas openness expresses dominance (exposure) versus enclosure of a location on an irregular surface. 'New' parameters, however, rarely are; many describe the same basic attribute of surface form and thus are redundant (Pike, 2001e). In geomorphology, for example, the hypsometric integral differs little from elevation skewness (Pike, 2001a). If, or to what extent, the two most recently proposed candidates mimic existing, and perhaps simpler, measures remains to be determined (Guth, 1999b; Pike, 2001d).

\section{Tectonic Geomorphology as Neo-Orometry}

Global DEMs of Earth and Mars, as well as coverage of Earth's seafloor and ice caps, have fostered terrain modeling at broad spatial and 
temporal scales (van der Beek and Braun, 1998; Clayton and Shamoon, 1999; Whipple and others, 1999). In some respects, this trend returns morphometry to its origins in the quantitative generalities sought by von Humboldt (1817, 1843c) and his successors (Sonklar, 1860, 1866; Stange, 1885), but with a sophistication and emphasis on geologic process that were absent from the older work (Hurtrez and others, 1999; Yamada 1999, 2001a, b; Bendick and Bilham, 2001; Bishop and others, 2002). Orometry, the 19th-Century measurement of mountains (Penck, 1894b), is echoed today in tectonic geomorphology, which interprets landscape evolution from DEM data and assumptions of physical process that reflect the interplay of mountain building and erosion in regions of active deformation (Summerfield, 2000; Burbank and Anderson, 2001; Pazzaglia and Knuepfer, 2001).

By testing theory in controlled experiments (Ahnert, 1966), the broadscale quantification of topography has helped transform tectonic geomorphology into one of the most active and exciting fields in the Earth sciences (Hovius, 1996; Talling, 1997; Miliaresis and Argialas, 1999a-c; Miliaresis, 2001a, b; Kühni and Pfiffner, 2001a, b; Dietrich and others, 2002). GTOPO30 and other DEM data are being used to model geodynamic and surface processes, rates, and physiographic effects (Whipple and Tucker, 1999; Rice-Snow and Russell, 2000; Montgomery and others, 2001; Montgomery and Brandon, 2002; Azor and others, 2002). In related work requiring large DEMs, classic drainage-basin morphometry has expanded beyond single catchments and fluvial systems (Strahler, 1956, 1958). Current applications include tidal creek systems (Cleveringa and Oost, 1999) and the hydrologic parsing of entire continents (Danielson, 1998; Kumar and others, 2000; Vaughn and others, 1999) and planets (Verdin and Verdin, 1999; Vörösmarty and others, 2000a; Cabrol and Grin, 2001; Smith and others, 2001).

\section{Biogeography}

The numerical modeling of terrain is now evident in landscape ecology and wildlife and conservation biology (Meisel and Turner, 1998). These fields traditionally have emphasized spatial over relief attributes of the Earth's surface (Gustafson, 1998; Li, Lu, and others, 2001; Raines, 2002). Although land-surface form affects distribution of plants and the fauna that need them for concealment, food, nesting, and other functions, few habitat models have incorporated topography (Vales, 1996). Even when included, characterization of the ground surface usually is limited to 
elementary DEM-derived parameters: elevation and slope gradient and aspect-which are insufficient for many field-biological applications.

Such attributes of terrain as roughness, which incorporates both slope steepness and spacing, and site position with respect to the nearest valley bottom or ridge crest are important to local fauna because they influence microclimate, cover from predation, and susceptibility to disturbance by humans. The literature on biogeography is starting to reflect a more complex numerical characterization of topography. Recent examples include topographic determinants of butterfly habitats (Fleishmann and Mac Nally, 2002), ruggedness indices that quantify topographic heterogeneity (Riley and others, 1999) and predict the distribution of musk oxen (Nellemann and Reynolds, 1997), and GIS models such as that by Gustafson and others (2001), which combines hillslope position and its correlation with soil moisture to model the response of salamanders to alternative plans for forest management.

\section{Ice-cap Morphometry}

Dating from the pioneering hypsometric curves of Greenland and the Arctic (Meinardus, 1926) and the first DEM of Antarctica (Budd and others, 1984), over two dozen bibliographic entries describe the morphometry of Earth's largest ice-covered surfaces. Topographic measurements are needed to understand the interaction of ice sheets with global climate and sea level. Much of the $10-25 \mathrm{~cm}$ rise in sea level over the last 100 years may reflect waning polar ice caps. Mass balance, which describes whether an ice sheet is growing, shrinking, or stable, may be estimated from data on the rate of ice thickening or thinning (Krabill and others, 2000). Because polar ice sheets are large, remote, and change slowly, systematic observations on elevation and thickness have been difficult to obtain.

Remote-sensing technology dramatically increased the ease of measurement (Bamber and others, 1998; Bindschadler and others, 1999; Liu and others, 1999; Thomas and others, 1999; Rémy and others, 2001). Not only have accurate DEMs been compiled for the major ice caps (Bingham and Rees, 1999; Bamber and others, 2001), but large 'ice basins' analogous to fluvial catchments have been delimited from the DEMs (Vaughn and other, 1999; Hardy and others, 2000). Other work has quantified subglacial bedrock surfaces and thus estimated ice-cap thickness and volume (Warner and Budd, 2000; Björnsson and others, 2000; Lythe and others, 2001). Not all high-latitude morphometry is of 
regional extent. Bintanja and others (2001), for example, have quantified fine-scale ripples in polar-cap ice.

\section{The Mars Global DEM}

Terrain modeling is indispensable to the investigation of planetary surfaces (Pike, 2001a). Extraterrestrial landforms recently studied from height measurements include impact craters, volcanoes, scarps, and other features on the Moon (Craddock and Howard, 1999), Mercury (Watters and others, 2002), Venus (Bulmer and Wilson, 1999; Herrick and Sharpton, 2000), and the satellites of Jupiter (Schenk and others, 2001; Schenk, 2002). Measurement-driven progress in the quantitative geomorphology of Mars has been spectacular. Over a dozen entries describe morphometric results from topographic data acquired by the Mars Orbiter Laser Altimeter (MOLA), a $10-\mathrm{Hz}$ pulsed infrared-ranging instrument operated in orbit around the planet from 1997 to 2001 aboard the Mars Global Surveyor.

As the mission progressed, a global DEM compiled from range measurements improved in spatial resolution from $59 \mathrm{~km}$ to $12 \mathrm{~km}$ and to as little as $230 \mathrm{~m}$ locally, and in vertical accuracy to $\pm 1 \mathrm{~m}$ (Neumann and others, 2001). The resulting global topographic map is the most accurate of any planet in the solar system (Smith and others, 1999; Zuber and others, 1998a, b, 1999, 2001). Geomorphic findings from the MOLA DEM include confirmation of the extraordinary smoothness of the planet's northern hemisphere (Aharonson and others, 1998), regional hypsometry and slope gradients (Head and others, 1999; Kreslavsky and Head, 2000; Aharonson and others, 2001), discovery of a new multi-ring impact basin (Frey and others, 1999), refinement of crater depth/diameter relations (Garvin and Frawley, 1998; Garvin and others, 2000), and delineation and interpretation of valley networks and watersheds (Smith and others, 2001; Williams and Phillips; Stepinski and others, 2002).

\section{Landslide-hazard Assessment}

The flurry of activity in mapping landslide susceptibility since its earlier mention in this series (Pike, 1999) warrants revisiting the topic. Because the morphology of landslide source-areas and deposits can be described in geometric terms, slope failure rivals flooding as the geomorphic hazard most amenable to analysis through terrain modeling. The spread of DEMs 
and GIS technology has shifted emphasis in morphometry from characterizing individual landslides (Collin, 1846; Simonett, 1967; Waltz, 1971 ) to regional assessment of slope stability (Jäger and Wieczorek, 1994; Montgomery and Dietrich, 1994; Atkinson and Massari, 1998; Dietrich and Montgomery, 1998b). Much of the recent work has involved the spatial modeling of landslide susceptibility, the relative likelihood that a hillside site will fail upon occurrence of a triggering event, such as an earthquake or heavy or persistent rainfall. Two dozen entries in this report sample a small fraction of the current literature on susceptibility mapping, which combines variously slope gradient, curvature, and aspect with geology, evidence of prior failure, and land use (Larsen and Parks, 1998; Mason and others, 1998; Pack and others, 1999; Bucknarn and others, 2001; Coe and Godt, 2001; Gritzner and others, 2001; Pike and others, 2001).

\section{Physics and Terrain Modeling}

Recent interest in theoretical aspects of terrain modeling by researchers who are physicists, mathematicians, or engineers rather than Earth scientists may reflect a maturing of the discipline (Arakawa and Krotkov, 1994; Brown and others, 1994; Dodds and Rothman,1999, 2000; Glanz, 1999). Complementing this trend, Earth scientists are beginning to publish on topography in physics journals (Clarke, 1997; Pastor-Satorras and Rothman, 1998a, b; Schörghofer and Rothman, 2001). Much of this new work was prompted by the use of topography in explicating fractalsurface phenomena (Dubuc and Dubuc, 1996; Struzik, 1996) and by recognition of self-organizing properties in the landscape (Bak and others, 1987; Halsey, 2000; Mandelbrot, 2002). More attention has been accorded to planimetric description of river networks (Tokunaga, 1994; Newman and others, 1997; Dodds and Rothman, 2001a, b, c) than to the more complicated problem of characterizing relief, or Z-domain, attributes of continuous topography (Mandelbrot, 1985; Koenderink and van Doorn, 1993, 1994, 1998).

\section{Hack's Law}

The post-World War II USGS geomorphologist John Hack combined terrain modeling with a more traditional interpretation of field observations (Hack and Goodlett, 1960; Hack, 1965). His enduring 1957 contribution, known as Hack's Law, is an empirical relation with moderate scatter, $L=1.4 A^{0.6}$, 
showing that drainage-basin area $A$ increases exponentially with channel length $L$. (see also, Makkaveev, 1955). The significance of the equation was discussed throughout the 1960s and 1970s, centering on debate over the exact value of the exponent-the observed range was 0.47-0.65-and whether it varied regionally and with basin size (Miller, 1958; Mueller, 1972, 1973; Moseley and Parker, 1973; Shreve, 1974). Advances in understanding steady-state scaling of landscape phenomena, resulting from DEM-based analysis of topography in the early 1990s, have revived interest in Hack's Law. Hovius (1996), for example, suggested that the equation was related to the spacing of streams draining mountain belts, while Rinaldo and Rodríguez-Iturbe (1998) considered Hack's Law and basin elongation to be an outgrowth of fractal properties. Among the most recent interpretations are those of Dodds and Rothman (2000, 2001a), Willemin (2000), Birnir and others (2001), and Sivapalan and others (2002).

\section{Broad-scale Visualization}

Vigil and others (2000) merged two existing digital images of the lower 48 United States, shaded relief and geologic time (expressed as geologicmap units), into one map, a colored three-dimensional perspective view of the landscape at 1:3,500,000 scale. The resulting digital 'tapestry' is among the more effective combinations of shaded relief with other spatial data and has potential for Earth-science education (Leech and others, 2002). The geologic map, a multi-color, non-uniform vector file, was converted to raster structure and overlaid on the shaded-relief file, a gray-scale raster at a uniform scale. Processing was not routine GIS. Differences between the source maps required various procedures to subdue or remove irregularities in the merged image. Adjusting transparency (opacity), color levels, and contrast of the geologic map to attain an aesthetic and visual balance between shaded relief and geologic-time units was an iterative, trial-and-error process. The final map, occupying a modest $700 \mathrm{MB}$, did not require high-end hardware or custom programming, but was processed on a PowerMacintosh desktop computer by Adobe Illustrator and Photoshop software. Barton and others $(2002,2003)$ have created a similar image of the entire North American continent at 1:8,000,000 scale from a later DEM (GTOPO30) and a combined geologic map of Canada, the U.S., and Latin America. Despite the reduced scale, this latest map successfully extends the original tapestry concept. 


\section{Other Topics}

Terrain modeling has progressed in areas besides those highlighted above. Over 150 references, in 24 of the many subject categories represented in the appended listing, convey the extent of recent developments in morphometry. Most of the following citations touch on several topics:

- ontology, or definition, of terrain and landforms, especially mountains (Agarwal and others, 1996; Mark and Smith, 2002a, b);

- conversion of contour lines to grid DEMs (Gousie, 1998; Gousie and Franklin, 1998; Franklin and Gousie, 1999);

- DEM error and accuracy (Webber, 1995; Giles and Franklin, 1996; Gao, 1997; Gesch, 1998; Duh and Brown, 1999; Lemmens, 1999; Toutin, 1999; Endreny and others, 2000; Gong and others, 2000; Krupnik, 2000; Rees, 2000; López, 2002);

- compression of elevation data (Franklin, 1995; Franklin and Said, 1995; Kidner and Smith, 1997; Ottoson, 2001; Park and others, 2001; Bjørke and Nilsen, 2002);

- impact of DEM error and grid spacing on terrain-modeling applications (Hunter and Goodchild, 1997; Brasington and Richards, 1998; Gesch, 1999; Guth, 1999c; Walker and Willgoose, 1999; Holmes and others, 2000; Wise, 2000; Wolock and McCabe, 2000; Canters and others, 2002);

- the triangulated irregular network, TIN (Brown and others, 1994; Mark, 1997; Ware and Kidner, 1997; Little and Shi, 1998, 2001; Park and others, 2001; Wang and others, 2001; Zhu and others, 2001);

- computing terrain parameters from square-grid DEMs (Weih and Smith, 1996; Jones, 1998; Defourny and others, 1999; Garbrecht and others, 1999; Guth, 1999a, b, 2001; Meyer and others, 2001; Luo, 2002; Shary, 2002; Shary and others, 2002);

- computing terrain parameters from elevation contours and flow lines (Schneider, 1998a, b; Menduni and Riboni, 2000; Mizukoshi and Aniya, 2002); 
- visibility analysis and viewsheds (Wang and others, 1996; De Floriani and Magillo, 1999; Franklin, 2000; Messina and Stoffer, 2000; Wang and others, 2000; Kidner and others, 2001; O'Sullivan and Turner, 2001);

- computer visualization of irregular surfaces (Banks and Wickens, 1997; Duchaineau and others, 1997; Valentine and others, 1998, 2001; Eckhardt and others, 2000; Gardner and others, 2000a, b; Malzbender and others, 2001; Mossman, 2001; Yokoyama and others, 2002);

- extracting drainage lines and watersheds from DEMs (Soille and Gratin, 1994; ESRI, 1997; Danielson, 1998; ASCE Task Committee, 1999; Band, 1999; Bertolo, 2000; Djokic and Ye, 2000; Garbrecht and Martz, 2000; Liang and Mackay, 2000; Saunders, 2000; Jones, 2002);

- hillside erosion and slope evolution (Pastor-Satorras and Rothman, 1998a, b; Katsube and Oguchi, 1999; Favis-Mortlock and others, 2000; Iwahashi and others, 2001; Roering and others, 2001);

- fluvial step-pools (Chin, 1999; Chartrand and Whiting, 2000; Duckson and Duckson 2001; Madej, 2001); Jackson and Sturm, 2002);

- self-similar and fractal properties of streams and topography (Tate, 1998a, b; Cleveringa and Oost, 1999; Fagherazzi and others, 1999a-c; Peckham and Gupta, 1999; Pelletier, 1999; Sulebak, 1999; Veneziano and Iacobellis, 1999);

- scaling of river networks and runoff processes (Dietrich and Montgomery, 1998a; Dodds and Rothman, 2000; Schmidt and others, 2000; Veneziano and Niemann, 2000a, b; Fekete and others, 2001; Tang and Day, 2000);

- aeolian dunes (Kar and others, 1998; Wadhawan, 1998; Gay, 1999; Goudie and others, 1999; Jimenez and others, 1999; Sauermann and others, 2000; Bishop, 2001; Al Harthi, 2002);

- glacial landforms (Davis, 1999; Evans, 1999; Etzelmüller and Björnsson, 2000; García-Ruiz and others, 2000; MacGregor and others, 2000; Li and others, 2001a, b);

- volcanic landforms (Rossi, 1999; Stevens and others, 1999; Wichman, 1999; Carn, 2000; Schenk and others, 2001; Stoddard and Jurdy, 2002); 
- submarine surfaces and features (Nolan and others, 1999; Adams and Schlager, 2000; Clague and others, 2000; McAdoo and others, 2000; Dunn and others, 2001; Mitchell, 2001);

- karst features (Magdalene and Alexander, 1995; Sykioti and others, 1996; Ferrarese and others, 1998; Whitman and others, 1999;

Denizman and Randazzo, 2000);

- relation of ground-surface form to soil properties (Vivas and Paz Gonzalez, 1998; Crawford and others, 1999; Thomas and others, 1999; Bochet and others, 2000; Florinsky and Kuryakova, 2000; Sulebak and others, 2000; Fraisse and others, 2001; Manning and others, 2001; Thompson and others, 2001; Florinsky and others, 2002);

- agricultural fields (Remond and others, 1999; Inamdar and Dillaha, 2000; Fraisse and others, 2001; Takken and others, 2001; Wilson and others, 2001; Planchon and others, 2002; Zobeck and Popham, 2002);

- predicting flood inundation (Cohen and Small, 1998; Ramsey and others, 1998; Small and Cohen, 1999; Bae and others, 2000; Bates and DeRoo, 2000; Marks and Bates, 2000; Nicholls and Small, 2002); and

- numerical classification of terrain, by types and regions (Dikau, 1996; Friedrich, 1996, 1998; Brabyn, 1997; Bivand, 1999; Gimel'farb and others, 1999; Miliaresis and Argialas, 1999a-c; Schmidt and Dikau, 1999; Verdin and Verdin, 1999; Cronin, 2000).

\section{New Books}

Book-length publications continue to mark advances in terrain modeling and its supporting technologies. Among recent volumes are those authored by Burbank and Anderson (2001) and edited by Wilson and Gallant (2000), Maune (2001), and Pazzaglia and Knuepfer (2001). Papers from three morphometry-oriented sessions of the 5th International Conference on Geomorphology in Tokyo (2001) are being edited by Evans, Dikau, Tokunaga, Ohmori, and Hirano for a 2003 book provisionally titled Concepts and Modeling in Geomorphology.

Publication of Terrain Analysis: Principles and Applications (Wilson and Gallant, 2000) was a major event. Celebrating the work of Ian Moore (1951-1993), the book began as the proceedings of a 1996 Australian workshop, Creation and Applications of DEMs in Land Resource 
Assessment. Much updated from the papers read at the meeting, the book focuses on TAPES (Terrain Analysis Programs for the Environmental Sciences), a set of computer algorithms for quantifying terrain with special reference to hydrology and ecology (for example, Moore and others, 1988). Among the most informative of the 16 chapters are the first five-by Gallant and Wilson, Hutchinson and Gallant, Wilson and Gallant (two), and Wilson and others (all 2000)-which introduce and describe the various TAPES programs. The remaining 11 articles report a variety of applications, some of which illustrate the chronic problem of noisy DEMs.

Digital Elevation Model Technologies and Applications, edited by David Maune (2001) for the American Society for Photogrammetry and Remote Sensing, is subtitled The DEM Users Manual. Prepared by industry specialists in remote sensing rather than by academic scientists, the book is strong on the basics of acquiring and preprocessing square-grid digital elevation data, principally for the U.S. Applications in terrain modeling per se are limited to a few examples. After an introduction to DEM terminology and concepts, the remaining 12 chapters address vertical datums, accuracy standards, the USGS National Digital Elevation Program, photogrammetry, IfSAR, Topographic LiDAR, airborne LiDAR bathymetry, Sonar, the various enabling technologies, a sampling of DEM applications, DEM quality assessment, and likely requirements of the DEM user. While useful, much of the material could quickly become dated by advances in techniques of data acquisition and processing.

Quantified topography is essential to the analysis of landscapes shaped by diastrophism. The last two chapters of Burbank and Anderson's (2001) textbook Tectonic Geomorphology draw from published research into the DEM-based modeling of geodynamic and surface process. Illustrated are elevation and slope distributions for highland subregions, drainage spacing as a function of mountain-belt width, valley height/width ratios and other morphometric attributes, and models of landscape evolution constructed from the diffusion equation and a range of assumptions about process and temporal and spatial scale. In addition, five of the eight papers in a special 2001 volume of the American Journal of Science edited by Pazzaglia and Knuepfer, The steady-state orogen: concepts, field observations, and models-by Whipple, Pazzaglia and Brandon, Montgomery, Willett and others, and Stark and Stark-contain DEM-based analyses of erosion and tectonism that contribute to understanding the evolution of mountain topography.

Two books, by Stout and others (2000) and edited by Stout and Blunt (2000), update the three-dimensional quantification of micro- and nano- 
surfaces from ultra-fine-scale DEMS. This 1990s breakthrough in technique revolutionized the field of industrial-surface metrology, terrain modeling's sister discipline in manufacturing and production engineering. Shorter advances in 3-D metrology include Stout and others (1999); Thomas and others (1999); Blunt and Stout (2001); Wieczorowski (2001); and Assender and others (2002). Among works of historical importance that have come to light are Abbott and Firestone (1933), Kramrisch (1935), and Schmaltz (1936). Pike (2000b, 2001b, c) explored the convergence of Earth-science and industrial practices of surface quantification.

\section{A New Internet Resource}

The visibility of terrain modeling on the World Wide Web grew in 2000 with the inauguration of an on-line bulletin board, The Geomorphometry Mailing List. Maintained by Dr. George Miliaresis, a former student of Demetre Argialas (Argialas and Miliaresis, 1997b, 2000, 2001) and now in the Department of Surveying and Regional Planning at the National Technical University of Athens, the English-language list had about 400 subscribers by late 2002 . The URL is http://groups.yahoo.com/group/geomorphometry/. Miliaresis' list "... points out information resources for ... geomorphometry and the processing of digital elevation models, related conferences, data availability, algorithms and methods, scientific news, etc. The aim is to promote geomorphometry to new scientists and to integrate advances in geomorphometry and news that are distributed in various fields (remote sensing, geography, geology, surveying, etc.)." Besides serving as a focus for the terrain-modeling community, the list supplements the aging 1999 on-line article Web Resources Compiled For Terrain Modeling, at http://www.agu.org/eos_elec/97260e.html. Other new Internet resources include Discoe (2002), on terrain rendering and animation, and Childs (2002), a repository of current hands-on experience in terrain modeling and digital mapping.

\section{Early Morphometry: Ridges and Watercourses}

About 200 of the bibliographic entries listed in this report are over fifty years old and half of them predate 1900 . The concepts evolved from 19th-Century orometry and later obsolete work, distant as they are, have shaped much of today's terrain modeling. John Playfair's (1802) 
explication of the ideas of James Hutton, for example, recognized not only an orderly confluence of streams and their valleys, but also that the upstream angle at which a tributary meets its trunk stream generally is acute (1802, p. 113-114). The latter observation, which was known to Immanuel Kant $(1803$, v. 3, p. 18) may be even older. A prescient mid19th Century contribution, although it little affected the science because it was so advanced for the time, is the 1834 paper by Julian Jackson, who devised a primitive-but unmistakable-precursor to the Gravelius-HortonStrahler system of stream ordering.

Among the best examples of current terrain modeling rooted in early practice is the geometric representation of topographic curvature. Two dozen entries in this report, which elaborate on the historic material discussed in Rieger (1997) and López $(1997,1999)$ as well as on my translations of short passages from some of the following citations, chronicle the 200-year evolution of mathematical definition of ridges, watercourses, and hillside flow-lines. The 19th-Century context is revealing: While German geographers were quantifying Küstenentwicklungen, 'coastal development' or more accurately its degree of planform convolution (Humboldt, 1817, 1835; Nagel, 1835; Reuschle, 1869) - an intricate coastline was thought to favor the rise of 'more advanced', i.e. industrialized, societies)-or calculating the volume and mean height of mountains and continents (Humboldt, 1843c; Koristka, 1858; Sonklar, 1872; Penck, 1886, 1894b), French civil engineers and mathematicians were developing a geometric model to characterize topography's most fundamental features.

Well before Arthur Cayley's 1859 paper "On hills and dales" and Carl Gauss' (1827) paper on curved surfaces, Dupuis de Torcy and Brisson (1808, reprinted in Brisson, 1829) conceptualized topographic ridges and valleys as special cases of downslope flow-lines normal to height contours. (Cayley and Gauss cited neither of these nor their other French predecessors identified below.) This early (the first?) representation of the land surface by descriptive geometry-Barnabé Brisson, a geometer and civil engineer, was a student of Gaspard Monge, the inventor of descriptive geometry-arose from a practical problem. The French had been the first to map height contours regionally, but also were leaders in the engineering of modern canals. The lay of the land and the design compromises it forced upon civil engineers were major considerations in estimating the cost of canals, which could either follow a straight course or trace a sinuous path dictated by the terrain. A canal aligned along relief contours resulted in a longer and less direct course, but required fewer expensive earthworks and locks. Dupuis de Torcy and Brisson 
proposed applying descriptive geometry to the spot heights indicated on topographic maps, rather than employing the usual field surveys, to locate the divides that separate adjacent large watersheds-thus identifying candidate canal-routes and facilitating cost estimates for cutand-fill engineering.

This pioneering work in applied surface-geometry was picked up by J.C. Saint-Venant (1852). The French mathematician and civil engineer was perhaps the first to define ridges and valleys explicitly as points of minimum slope-compared to other points at the same elevation-although he did not specify the zero-sloping flow-lines that form the drainage pattern. Shortly thereafter, his countryman P.-E. Breton de Champ (1854) offered a new theorem to redress this shortcoming and elaborated his proposed solution in subsequent papers $(1861,1867,1870,1877)$. Breton de Champs' earliest work precedes the 1858 paper "Démonstration d'une propriété général des surfaces fermées" of Ferdinand (née Frédéric) Reech, the Alsatian thermo- and hydrodynamicist who specified 'critical points' of zero slope on continuous smooth surfaces in descriptive-geometric terms. (A free English translation of Reech's paper was rendered by Warntz, 1967). The hydrodynamicist and mathematical physicist Joseph Boussinesq, a pupil of Saint-Venant, also noted that Saint-Venant's 1852 formulation was incomplete, and developed his own ideas (Boussinesq, 1871, 1872a, b) in a series of exchanges with the French scientist and mathematician M.E.C. Jordan $(1872 a, b, c)$. None of the post-1858 works referred to here cite Reech's paper.

The problem of describing slope curvature appears to have attracted little further attention until Müller (1912) cited some of the older French papers in his textbook, wherein he ascribed the earliest descriptive-geometric treatment of ridges and watercourses to Dupuis de Torcy and Brisson (1808). Evidently stimulated by Müller's retrospective, Rothe (1915) further reviewed the French literature, criticizing the formulation of Jordan, and devised yet another geometric definition of ridges and valleys that he claimed solved the problem. Decades lapsed until Rothe's definition was noticed by present-day investigators concerned with the mathematical description of complex surfaces other than topography. Recently, Rothe's work was rediscovered by López $(1997,1999)$ and by Rieger (1997; pers. comm., e-mail, 09/2001), who disputes the Rothe solution and prefers Jordan's (1872a) definition of ridges and watercourses. Not all contemporary work stems from the foregoing evolution. The characterization of terrain-surface curvature by Shary (2001) and Shary and others (2002), for example, is grounded in the 
concepts articulated by Gauss (1827) as also, evidently, has been the curvature-based terrain work of Krcho $(1983,1999)$.

The descriptive-geometric representation of ridge lines and watercourses is powerful and widely applied (Reeb, 1946; Kweon and Kanade, 1994; Brassard, 1998; Rana and Morley, 2002). Terrain-derived concepts have helped shape research in computer vision and image segmentation, much of which characterizes surfaces other than terrestrial landscapes (Burl and others, 1994; López, 1997; Rieger, 1997; Souille, 1999). The most recent development in machine vision, on-the-fly rendering of digital terrain (Duchaineau and others, 1997), brings the descriptive geometry of irregular surfaces full circle, to natural topography, as computer-game developers attempt to create realistic animations of landscapes for commercial video products (Lindstrom and others, 1996; Blow, 2000; Discoe, 2001). This cutting-edge application of terrain modeling to leisure-time mass entertainment probably commands more financial resources than all geomorphic and hydrologic morphometry combined. Most topographic animation employs some variant of the TIN model (Ware and Kidner, 1997). The military follows a similar approach in some of its three-dimensional simulations of battlefield scenarios (Banks and Wickens, 1997; Thompson and others, 1998), although other defense applications are based on square-grid DEMs (Franklin, 1994).

\section{Citation Accuracy and Additions}

Incorrect and incomplete citations-through failure to consult original works, careless manuscript preparation, unproofed typesetting, or, recently, computer errors-are an irritating fact of life. The author tried not to perpetuate them here-or worse, create new ones. However, mistakes invariably enter a large and detailed reference list even when, as in this case, all entries were recorded by one individual in a computer file that has been repeatedly checked and updated. Instances of the errors noted above remain and are the author's responsibility. May they be few and not unduly misleading. Mistakes and omissions found by readers should be referred to the author so that corrections can be released in an addendum or in a more formal publication of the bibliography.

Contributions to this archive from its readers would help fill gaps in the terrain-modeling record, improve annotation, and correct mistakes. Especially desired are current and historical morphometric references that are not readily available in the United States, such as non-English- 
language publications from central and eastern Europe and declassified military reports. Work from France and India also is underrepresented. The earlier bibliographies in this series are available for exchange for copies of contributed papers. To reduce ambiguity and ensure accuracy, please send reprints or photocopies of contributions rather than just the citations, if possible. However, new entries can be added from the following brief information:

1. photocopy of title page, or

- title of the work, and

- the name(s) of author(s); surname plus two initials (or, if one given name, then spelled out)

2. year of publication

3. complete citation of journal or other form of publication (book, conference proceedings, and so forth), including volume number, issue number, and inclusive pages. For meetings give location and dates; for books the name of city and publisher

4. for publications in languages other than French, German, and Spanish, an English translation of the title and source only.

Address correspondence to:

Richard J. Pike

M/S 975

U.S. Geological Survey

345 Middlefield Road

Menlo Park, CA 94025 U.S.A.

FAX [650] 329-4936

e-mail: rpike@usgs.gov

Acknowledgments: I thank Igor Florinsky for his list of Russian references and Stefan Rasemann, Antonio López, Ronny Peikert, and Joachim Rieger for copies of French and German publications as well as leads to further sources of information. Comments by USGS colleagues Phil Stoffer and Charles Powell II improved the report.

\section{References}

Pike, R.J., 1993, A bibliography of geomorphometry, with a topical key to the literature and an introduction to the numerical characterization of topographic 
form: U.S. Geological Survey Open-file Report 93-262A, 132 p. Open-file Report 93-262B.

------ 1995, A bibliography of geomorphometry, the quantitative representation of topography-Supplement 1.0: U.S. Geological Survey, Open-file Report 95$046,30 \mathrm{p}$.

------ 1996, A bibliography of geomorphometry, the quantitative representation of topography-Supplement 2.0: U.S. Geological Survey, Open-file Report 96$726,52 \mathrm{p}$.

------ 1999, A bibliography of geomorphometry, the quantitative representation of topography-Supplement 3.0: U.S. Geological Survey, Open-file Report 99$140,57 \mathrm{p}$. 


\title{
BIBLIOGRAPHY — ADDITIONS
}

\begin{abstract}
A
Aasgaard, Rune, and Sevaldrud, Thomas, 2001, Distributed handling of level of detail surfaces with binary triangle trees, in ScanGIS'2001, Scandinavian Research Conference on Geographical Information Science 8th, Ås, Norway, 25-27 June, Proceedings: p. 45-58;

$<$ http://www.nlh.no/conf/scangis2001/papers/27.pdf>. [modifies the ROAM algorithm; based on J. Blow's 2000 paper]
\end{abstract}

Abbott, E.J. and Firestone, F.A., 1933, Specifying surface quality-a method based on accurate measurement and comparison: Mechanical Engineering, v. 55, no. 9, p. 569-72. [famous early metrology paper; depth/\% bearing area curves fr. profilograph $\approx$ hypsometric curves!]

Abrahams, A.D., 1970, An evaluation of Melton's order-by-order growth analysis: Australian Geographical Studies, v. 8, no. 1, p. 57-70. [o-b-o slope coeff. neither indicates remaining relief nor relief lowered as net grows]

Abrahams, A.D., 1970, Towards a precise definition of drainage basin axis-comment: Australian Geographical Studies, v. 8, no. 1, p. 84-87. [criticizes Ongley's 1968 measure of basin axis \& proposes alternatives]

Abrahams, A.D., 1972, Drainage densities and sediment yields in eastern Australia: Australian Geographical Studies, v. 10, no. 1, p. 19-41. [Dd/Sy relation largely similar to that of USA]

Abrahams, A.D., 1972, Factor analysis of drainage basin properties-Evidence for stream abstraction accompanying the degradation of relief: Water Resources Research, v. 8, no. 3, p. 624-633. [5 var., 3rd. order; cautious use of FA]

Ackermann, F.E., 1979, The accuracy of digital terrain models, in Photogrammetric Week, 37th, 2428 September, University of Stuttgart, Proceedings: p. 113-143. [experimental tests]

Ackermann, F.E., 1994, Digital elevation models-techniques and applications, quality standards, development: Atlanta, GA, IAPRS, v. 30/4, Comm. IV, p. 421-432. [review of photogrammetric DEM issues]

Ackermann, F.E., 1996, Techniques and strategies for DEM generation, in Digital Photogrammetry, an addendum to the Manual of Photogrammetry: Bethesda MD, American Society for Photogrammetry and Remote Sensing, p. 135-147; see also http://phot.epfl.ch/workshop/wks96/art_3_4.html. [topo parameters for quality control]

Ackermann, F.E, and Krzystek, P., 1995, New investigations into the technical performance of automatic DEM generation, in ASPRS/ACSM annual convention, Charlotte NC 1995, Proceedings: v. 2, p. 488-500; http://phot.epfl.ch/workshop/wks96/art_3_4.html. [the MATCH-T system creates DEMs fr digital photogrammetry]

Adams, E.W., and Schlager, Wolfgang, 2000, Basic types of submarine slope curvature: Journal of Sedimentary Research, v. 70 , no. 4, p. 814-828. [of 150 seismic profiles, $12 \%$ are linear, $20 \%$ exponential, \& $1 / 2$ Gaussian]

Adams, E.W., Schlager, Wolfgang, and Anselmetti, F.S., 2001, Morphology and curvature of delta slopes in Swiss lakes-lessons for the interpretation of clinoforms in seismic data: Sedimentology, v. 48, no. 3, p. 661-679. [curve-fitting fr Adams \& Schlager 2000; slope h \& angle \& break depth] 
Adams, E.W., Schlager, Wolfgang, and Wattel, Evert, 1998, Submarine slopes with an exponental curvature: Sedimentary Geology, v. 117, nos. 3-4, p. 135-141. [of 120 seismic profiles, 18 are concave-upward exp.]

Agarwal, Pankaj, de Berg, Mark, Bose, Prosenjit, Dobrint, Katrin, van Kreveld, Marc, Overmars, Mark, de Groot, Marko, Roos, Thomas, Snoeyink, Jack, and Yu, Sidi, 1996, The complexity of rivers in triangulated terrains, in Canadian Conference on Computational Geometry 8th, CCCG'96, August 12-15, Carleton University, Ottawa, Proceedings: p. 325-330. [extend formal definitions of Frank et al. 1986; if terrain has $n$ triangles, then $C$, in no. line segments, $\left.\approx Q\left(n^{3}\right)\right]$

Aggarwal, S., and eight others, 2000, Spontaneous ordering of oxide nanostructures: Science, v. 287, no. 5461, p. 2235-2237. [tall conical hillocks of $\mathrm{PdO}_{2}$; height, base diam., areal density on film]

Agterberg, F.P., 1999, Review of 'Fractals and Chaos in Geology and Geophysics, 2nd Ed.' by Donald L. Turcotte: Computers and Geosciences, v. 25, no. 1, p. 93-99. [likes it; adds multifractals, self-org. criticality, wavelets; difficult material well explained]

Aharonson, Oded, Zuber, M.T., Neumann, G.A., and Head, J.W. III, 1998, Mars-northern hemisphere slopes and slope distributions: Geophysical Research Letters, v. 25, no. 24, p. 44134416. [Elev. \& slope of var. geol-topo provinces (v. smooth); comp. w/ other planets]

Aharonson, Oded, Phillips, R.J., Rothman, D.H., Zuber, M.T., and Williams, R.M.E., 2000, Valley networks and topographic gradients on Mars-correlations and their dependence on scale (abs.): Eos Transactions of the American Geophysical Union, v. 81, no. 48 (Supplement, P52C-05), p. F773. [local slope (fr DEM) agrees best w/ network direction at $90 \mathrm{~km}$ ]

Aharonson, Oded, Zuber, M.T., and Rothman, D.H., 2001, Statistics of Mars' topography from the Mars Orbiter Laser Altimeter-slopes, correlations, and physical models: Journal of Geophysical Research, v. 106, no. E10, p. 23,723-23,735. [regional hypsometry, profiles, slope histograms, PSD]

Ahmadzadeh, M.R., and Petrou, Maria, 2001, Error statistics for slope and aspect when derived from interpolated data: IEEE Transactions on Geoscience and Remote Sensing, v. 39, no. 9, p. 18231833. [mean \& variance of model error distr.= f(terrain roughness \& subsampling rate)]

Ahnert, Frank, 1966, Zur Rolle der elektronischen Rechenmaschine und des mathematischen Modells in der Geomorphologie (in German): Geographische Zeitschrift, v. 54, no. 2, p. 118-133. [suggests volume \& hypsometry can be calc. by computer]

Akagiri, Takekazu, Niwa, Shunji, Suzuki, Katuyoshi, and Nemoto, Masami, 1990, A research of slope failure using orthophotomaps: Bulletin of the Geographical Survey Institute, v. 35, p. 35-45. [5-m DEM descr. individ. slides; slope, catchment area \& soil depth control slides]

Al-Harthi, A.A., 2002, Geohazard assessment of sand dunes between Jeddah and Al-Lith, western Saudi Arabia: Environmental Geology, v. 42, no. 4, p. 360-369. [linear h/W fit for 30 barchans has highest R2 of 21 correls.]

Allemand, P., and Thomas, P.G., 1995, Localization of Martian ridges by impact craters-mechanical and chronological implications: Journal of Geophysical Research, v. 100, no. E2, p. 3251-3262. [distr. of ridge spacing \& ridge-crater distance; linear rel. of ridge width to graben width]

Allen, P.A., and Hovius, Niels, 1998, Sediment supply from landslide-dominated catchments-implications for basin-margin fans: Basin Research, v. 10, no. 1, p. 19-35. [basin/fan A ratios for arid-area fans $(n=116)$ vary widely $(0.1-10.0) ; 35$ sets of $\boldsymbol{c} \& \boldsymbol{n}$ values fr power-law fits in literature] 
Alsdorf, D.E., and Smith, L.C., 1999, Interferometric SAR observations of ice topography and velocity changes related to the 1996, Gjálp subglacial eruption, Iceland: International Journal of Remote Sensing, v. 20, no. $15 \& 16$, p. 3031-3050. [pre- \& post-eruption topo. from ERS-1/2 data on Vatnajökull ice cap]

American Society of Photogrammetry, 1978, Digital Terrain Models (DTM) Symposium, St. Louis, Missouri, May 9-11, Falls Church, VA, Proceedings: 624 p. [first-ever big DEM meeting; all presentations; only Mark (p. 24-31) \& Peucker et al. (p. 516-540) commonly cited now]

Anbalagan, R., 1992, Terrain evaluation and landslide hazard zonation for environmental regeneration and land use planning in mountainous terrain, in Bell, D.H., ed., Landslides, International Symposium 6th, 10-14 February, Christchurch NZ, Proceedings: Rotterdam, Balkema, v. 2, p. 861-868. [no DEM; terrain facets; variables include slope type $\&$ angle, $\&$ relief]

Andrews, J.T., 1961, The devlopment of scree slopes in the English Lake District and Central Labrador: Cahiers Géographie de Québec, v. 10, p. 219-230. [measured \& compared profiles of talus slopes]

Andrews, J.T., 1971, Quantitative analysis of the factors controlling the distribution of corrie glaciers in Okoa Bay, East Baffin Island (with particular reference to global radiation, in Morisawa, M.E., ed., Quantitative geomorphology-some aspects and applications, Binghamton, NY, Annual Geomorphology Symposia Series, 2nd, October 15-16, Proceedings: p. 223-241. [size, elev., geometry, azimuth, \& spatial clustering for 165 cirques]

Andrews, J.T., and Dugdale, R.E., 1971, Quaternary history of Northern Cumberland Peninsula, Baffin Island, N.W.T., Part V-factors affecting corrie glacierization in Okoa Bay: Quaternary Research, v. 1, no. 4, p. 532-551. [details \& expanded analysis of $17 \times 165$ dataset in Andrews 1971]

Anonymous, 1963, Some recent developments in hill shading from air photographs in the Directorate of Overseas Surveys: Survey Review, v. 17, no. 127, p. 3-11. [pre-digital UK state-of-art; effective combination of layer tint, relief shading, \& contours]

Anonymous, 1972, Automatic contouring: The Military Engineer, v. 64, no. 420 (July-August), p. 271. [ConPlot-II software interpolates 4 elevs. fr UNAMACE DEM; must smooth by editing]

Anonymous, 1990, Firefinder mask considerations, in Tactics, Techniques, and Procedures for Field Artillery Target Acquisition: Headquarters, Department of the Army, Washington, D.C., FM 6-121, Appendix F, 5 p. http://www.adtdl.army.mil/cgi-bin/atdl.dll/fm/6-121/appf.pdf. [explains one current military implementation of terrain mask-angle]

Anzidei, Marco, 1998, The marine digital terrain model of the Panarea Caldera (Aeolian Islands, southern Italy): Annali di Geofisica, v. 41, no. 2, p. 265-270. [active volc.; differential GPS \& echo-sounding; $+30 \mathrm{~cm}$ XY \& $\pm 10 \mathrm{~cm} \mathrm{Z} \mathrm{accy.]}$

Anzidei, Marco, Baldi, Paolo, Chiocci, F.L., Marsella, Maria, Martorelli, Eleonora, and Zanutta, Antonio, 2000, Integrazione tra un aerophotogrammetrico e batimetria swath-it DTMM (digital terrain \& marine model) del versante orientale e meridionale dell'Isola di Palmarola (Lazio) (in Italian with english abstract \& figure captions): Bolletino della Società Geologica Italiana, v. 119, no. 3, p. 767-775. [how disparate subaerial \& submarine data were combined in one homogeneous $1.0 \mathrm{~m}$ 'DTMM']

Apaphant, M., and Bethel, J.S., 1997, Semi-automated conversion of hardcopy contour maps to digital form for DEM applications in GIS, in GIS/LIS'97 Annual Conference and Exposition, 28-30 October, Cincinnati OH, Proceedings: p. 710-718. [no info] 
Arakawa, K., and Krotkov, E., 1994, Modeling of natural terrain based on fractal geometry: Systems and Computers in Japan, v. 25, no. 11, p. 99-113. [method for computing $\boldsymbol{D}$ from a variogram; route planning for exploration by autonomous robots]

Argand, Émile, 1912, Sur de drainage des Alpes Occidentales et les influences tectoniques (in French): Proc. Verb. Soc. Vaudoise des Sc., Nature (Lausanne), 03 Avril, p. II-V. [1st used term 'summit level', a '... surface defined by envelope of present-day summits ...']

Argialas, D.P., and Miliaresis, G.Ch., 1996, Physiographic knowledge acquisition-identification, conceptualization, and representation, in Annual Convention, American Society for Photogrammetry and Remote Sensing, Proceedings: v. 1, p. 311-320. [expert systems: 1st of their Basin \& Range morphometry]

Argialas, D.P., and Miliaresis, G.Ch., 1997a, An object oriented representation model for the landforms of an arid climate intermontane basin-case study of Death Valley, California, in Annual Conference 23rd, Remote Sensing Society, Proceedings: p. 199-205. [expert systems: 2nd of their Basin \& Range work]

Argialas, D.P., and Miliaresis, G.Ch., 1997b, Landform spatial knowledge acquisition-identification, conceptualization and representation, in Annual Convention, ACSM (57th)/ASPRS (63rd), Seattle WA, April 7-10: Technical Papers, p. 733-740. [expert systems: 3rd of their Basin \& Range work]

Argialas, D.P., and Miliaresis, G.Ch., 2000, Physiographic region interpretation-formalization with rule-based structures and object hierarchies: International Archives of Photogrammetry and Remote Sensing, v. 33, Part B4, p. 91-98. [knowledge-based expert-system relates Basin \& Range physiographic features, topographic forms, and landforms]

Argialas, D.P., and Miliaresis, G.Ch., 2001, Human factors in the interpretation of physiography by symbolic and numerical representations within an expert system, in Hoffman, R.R., and Markman, A.B., eds., Interpreting remote sensing imagery-human factors: Boca Raton FL, Lewis Publ. (CRC), p. 59-81. [extracts mountains from GTOPO30, then gets size, elong., azimuth, elev., roughness (elev. std. dev.), relief, hyps. integr., \& slope]

Armstrong, A.C., 1987, Slopes, boundary conditions, and the development of convexo-concave forms-some numerical experiments: Earth Surface Processes, v. 12, no. 1, p. 17-30. [var. slope profiles fr simple implementation of continuity-eqn model]

Arrighi, Patrice, and Soille, Pierre, 1999, From scanned topographic maps to digital elevation models, in Jongmans, D., Pirard, E., and Trefois, P., eds., Geovision'99, International Symposium on Imaging Applications in Geology, May, Université de Liège, Belgium, Proceedings: p. 1-4. [complicated by textured backgrounds \& data layers overlaid on contours]

Arthur, D.W.G., 1962, Some systematic visual lunar observations, in Kopal, Zdenêk, and Mikhailov, Z.K., eds., The Moon, IAU symposium no. 14, Pulkovo Observatory, USSR, December 1960, London \& New York, Academic Press, p. 317-324. [d/D, h/D (good eqn), floor-width ratios for simple craters; gen'l dome dimensions]

ASCE Task Committee, 1999, GIS Modules and Distributed Models of the Watershed: Reston VA, American Society of Civil Engineers, 120 p. [review \& guide to DEM, TIN, DLG, \& GIS applics. (DEM-to-watershed transformation, etc.) \& software (9 pkgs.), big biblio]

Assender, Hazel, Bliznyuk, Valery, and Porfyrakis, Kyriakos, 2002, How surface topography relates to materials' properties: Science, v. 297, no. 5583, p. 973-976. [emph. soft-surface applics; relief, spacing, anisotropy; 2D autocorrel. fcn.] 
Atkins, Robert, 1994, TEC and TRAC to continue work on terrain resolution LOS sensitivity study plan: Digital Data Digest (USACE/TEC), v. 4, no. 1, p. 5-7. $\quad$ [effort to improve line-of-sight calcs.; final report issued $\sim 1996$ ]

Atkinson, P.M., 1999, Geographical information science-geostatistics and uncertainty: Progress in Physical Geography, v. 23, no. 1, p. 134-142. [several refs. on error in DEM's]

Atkinson, P.M., and Massari, Remo, 1998, Generalised linear modelling of susceptibility to landsliding in the central Apennines, Italy: Computers and Geosciences, v. 24, no. 4, p. 373-385. [GLM; geology \& slope most signif.; results diff. for active vs. dormant slides]

Atkinson, P.M., Jiskoot, Hester, Massari, Remo, and Murray, Tavi, 1998, Generalised linear modelling in geomorphology: Earth Surface Processes and Landforms-Technical and Software Bulletin, v. 23, p. 1185-1195. [unlike mult. regression, GLM combines continuous \& categorical var.]

Augustinus, P.C., 1992, The influence of rock mass strength on glacial valley cross-profile morphometry - a case study from the southern Alps, New Zealand: Earth Surface Processes and Landforms: v. 17 , no. 1 , p. 39-51. [form ratio, shape factor, drainage density, \& 3 coeff. fr quadratic curves (easier to fit to small-scale map); correl. analysis]

Azor, Antonio, Keller, E.A., and Yeats, R.S., 2002, Geomorphic indicators of active fold growth-South Mountain-Oak Ridge Anticline, Ventura Basin, southern California: Geological Society of America Bulletin, v. 114, no. 6, p. 745-753. [quant. modeling of tectonic geomorphology; elev, distance, sinuosity, valley $\mathrm{h} / \mathrm{W}$, hypsom. integr., drainage density]

\section{B}

Badura, Janusz, and Przybylski, Boguslaw, 1993, An attempt at application of selected morphometric methods to estimation of neotectonic movements in the Sudety Mountains, SW Poland, and their foreland (in Polish with English summary \& figure captions): Folia Quaternaria, v. 64, p. 43-53. [isoline maps of valley (same stream order) height \& stream length]

Bae, D.-H., Kim, J.-H., and Kwon, W.-T., 2000, A feasibility study of TOPMODEL for a flood forecasting model on a single watershed (in Korean with English abstract): Journal of Korea Water Resources Association, v. 33, no. 1, p. 87-97. [conclude is OK on Soyang River basin, thus OK for all Korea]

Bak, Per, Tang, Chao, and Wiesenfeld, Kurt, 1987, Self-organized criticality-an explanation of 1/f noise: Physical Review letters, v. 59, no. 4, p. 381-385. [their earliest statements of SOC; the sand-pile experiment; 'dynamical systems with spatial degrees of freedom naturally evolve into a self-organized critical point. Flicker noise, or $1 / f$ noise, can be identified with the dynamics of the critical state. This picture also yields insight into the origin of fractal objects']

Bald, William, 1841, An account of the construction of the models of the island of Achil, Clare Island, and the south-western district of Mayo, in Ireland: Report of the Tenth Meeting of the British Association for the Advancement of Science-Notices and abstracts of communications, Geology Section, Glasgow, August 1840, v. 9, p. 126-127. [quite exact; 4 \& 8 in./mile; no VE; elevs fr. level, theodolite, sextant, \& barometer]

Bamber, J.L, Ekholm, S., and Krabill, W., 1998, The accuracy of satellite radar altimeter data over the Greenland ice sheet determined from airborne laser data: Geophysical Research Letters, v. 25, no. 16, p. 3177-3180. [new 2.5-km DEM fr ERS-1; error >w/ slope due to surface roughness]

Bamber, J.L, Ekholm, S., and Krabill, W., 2001, A new, high-resolution digital elevation model of Greenland fully validated with airborne laser altimeter data: Journal of Geophysical Research, v. 104 , no. B4, p. $6733-6745$. [new 1-km DEM compiled fr var. sources; mean accuracy $=-0.33 \pm 7 \mathrm{~m}$ ] 
Bamber, J.L., Muller, J.P., and Mandanayake, A., 1997, A global 5 arc minute digital elevation model derived from the geodetic phase of ERS-1, in ERS symposium on space at the service of our environment, 3rd, Florence, IT, March 17-21, Proceedings: European Space Agency report SP414 , p. 1779-1787. [to be used in future updates of GTOPO30]

Bamber, J.L., Vaughan, D.G., and Joughin, lan, 2000, Widespread complex flow in the interior of the Antarctic ice sheet: Science, v. 287, no. 5456, p. 1248-1250. [DEM fr. ERS-1 radar altimetry + 1983 Drewry atlas]

Banavar, J.R., Maritan, Amos, and Rinaldo, Andrea, 1999, Size and form in efficient transportation networks: Nature, v. 399, no. 6732, p. 130-132 (\& comments by Painter, Haff, 2000, v. 408 p. $159-$ 160 ; reply p. 160). [allometric general size/flow rate relation \& theory includes river basins]

Band, L.E., 1999, Spatial hydrography and landforms in Longley, P.A., Goodchild, M.F., Maguire, D.J., and Rhind, D.W., eds., Geographical Information Systems, v. 1, Principles and Technical Issues, 2nd ed.: New York, Wiley, p. 527-542. [reviews DEM-to-watershed work; problems with GRASS software]

Banerdt, W.B., 2000, Surface drainage patterns on Mars from MOLA topography (abs.): Eos Transactions of the American Geophysical Union, v. 81, no. 48 (Supplement, P52C-04), p. F773. [possible patterns traced fr DEM slopes yield 4 mega-basins]

Banerjee, Paramesh, 1998, Gravity measurements and terrain corrections using a digital terrain model in the NW Himalaya: Computers and Geosciences, v. 24, no. 10, p. 1009-1020. [optimizes corrections; improves on classic (Hammer 1939) method]

Banks, Rachel, and Wickens, C.D., 1997, Commanders' display of terrain information-manipulations of display dimensionality and frame of reference to support battlefield visualization: Technical Report ARL-97-12/ARMY-FED-LAB-97-2, Aviation Research Lab, University of Illinois at UrbanaChampaign; for U.S. Army, Aberdeen Proving Ground, MD and Ft. Hauchuca, AZ, Contract DAAL 01-96-2-0003ARL, 62 p. [perception experiments; maps better than 3D at distance est., but 3D > maps for LOS; etc.]

Bannister, E.N., 1980, Hypsometries of Michigan's southeastern lake plain: Journal of Great Lakes Research, v. 6, no. 2, p. 154-163. [channel geometry, hypsometry]

Bannister, E.N., 1982, Hypsometric curve variance and drainage basin planforms, in Larimore, A.E., ed., Studies in fluvial geomorphology and morphometry; the collected papers of Everette N. Bannister 1948-1979; a memorial volume: Ann Arbor, MI, Univ. Michigan, Geography Dept., Michigan Geographical Publications, no. 27, p. 87-106. [hypsometric analysis, mathematical methods]

Barlow, N.G., 1994, Sinuosity of Martian rampart ejecta deposits: Journal of Geophysical Research, v. 99, no. E5, p. 10,927-10,935. [the old area/perimeter relation; calc. 'lobateness' $=\mathbf{P} /(4 \pi \mathbf{A})^{0.5}$ for 2213 craters; results differ fr Kargel 1986]

Barrio, G.A.B. del, and Diez, J.C., 1993, The choice of cell size in digital terrain models-an objective method, in Robinson, M., ed., Methods of Hydrological Basin Comparison: Wallingford, UK, Institute of Hydrology (now Centre for Ecology and Hydrology) Report no. 120, p, 190-196. [used 'information theory']

Barrio, G.A.B. del, Puigdefabregas, Juan, and Diez, Carlos, 1997, Response of high mountain landscape to topographic variables-Central Pyrenees: Landscape Ecology, v. 12, no. 2, p. 95115. [statistical land-type regionalization from DEM-based variables]

Barry, R.G., 1961, The punched card and its application in geographical research: Erdkunde, v. 15, p. 140-142. [early automated data handling] 
Barton, K.E., Howell, D.G., Vigil, J.F., Ciener, Jane, and Lesle, Timothy, 2002, The North America tapestry of time and terrain (abs.): Geological Society of America, Annual Meeting, Denver, CO, 2730 October, paper no. 217-1; http://gsa.confex.com/gsa/2002AM/finalprogram/abstract_43524.htm. [broad-scale computer visualization combining shaded relief \& geology extended to an entire continent]

Barton, K.E., Howell, D.G., Vigil, J.F., Reed, J.C., Jr., and Wheeler, J.O., 2003, The North America tapestry of time and terrain: U.S. Geological Survey, Geologic Investigations Series map I-2781, scale, $1: 8,000,000$, in press. [extension of 1:3.5M conterminous U.S. tapestry combining digital maps of shaded relief (gray scale) \& geologic time units (color)]

Basu, Atanu, and Saxena, N.K., 2002, Bathymetry data correction using global optimization method: Marine Geodesy, v. 25, no. 1, p. 37-60. [old data upgraded by nonlinear inversion to fill gaps in modern data]

Bates, P.D., and De Roo, A.P.J., 2000, A simple raster-based model for flood inundation simulation: Journal of Hydrology, v. 236, nos. 1-2, p. 54-77. [tests fr different DEMs; low-relief terrain requires high-accuracy data]

Baudemont, Frédéric, and Parrot, J.-F., 2000, Structural analysis of DEM's by intersection of surface normals in a three-dimensional accumulator space: IEEE Transactions on Geoscience and Remote Sensing, v. 38, no. 3, p. 1191-1198. [pattern-recognition approach to extract morphologic features]

Bauer, J., Rohdenburg, H., and Bork, H.-R., 1985, Ein digitales Reliefmodell zur Berechnung geoökologisch relevanter morphographischer Parameter (A digital relief model to calculate geoecologically relevant morphographic measures): Landschaftsökologisches Messen und Auswerten, v. 1 , no. $2 / 3$, p. 117-123. [DEM-based modeling of continuous topography]

Baulig, Henri, 1928, Le Plateau Central de la France et sa bordure Méditerranéene-Étude morphologique: Thèse d'Etat, Paris, Armand Colin, paging unknown. [mapped by summit-level meth; used spot-height freq. fr hachured-only maps]

Baumann Elizabeth, 1914, Morphometrie des Greifswalder Boddens: Universität Greifswald, Ph.D. dissertation, Jahresbericht der Geographischen Gesellschaft Greifswald 1914/15, v. 15, p. 1-44. [morphom. of estuary seafloor fr maps \& charts; much lit. \& technique review; bathym. curve; area/depth \& slope, 'coastal development', vol., mean depth]

Beardmore, Nathaniel, 1851, Manual of Hydrology: London, Waterlow and Sons, 384 p. [dynamic adjustment of form to process re. hydraulic geometry]

Beasley, D.B., Huggins, L.F., and Monke, E.J., 1980, ANSWERS-A model for watershed planning: Transactions of the American Socirty of Agricultural Engineers, v. 23, no. 4, p. 938-944. [pioneering distributed-parameter model simulated runoff \& erosion in agric. watersheds; calc. slope fr grid DEM by best-fit plane]

Beasley, D.B., and Huggins, L.F., 1982, ANSWERS—User's manual: U.S. EPA-905/9-82-001, Chicago, IL, 54 p. [see Beasley et al. 1980]

Beaty, C.B., 1956, Landslides and slope exposure: Journal of Geology, v. 64, no. 1, p. 70-74. [ $70 \%$ of slides $\mathrm{E}$. of Berkeley CA are on (shaded) slopes facing $\mathrm{N}$ or $\mathrm{E}]$

Beauvais, A.A., 1997, Analyse fractale des réseaux (in French), in Davy, Philippe, Guillocheau, François, and Hamelin, Bruno, eds., Géomorphologie-Processus et Modélisation: Rennes, Geosciences-Rennes, p. 44-45. [brief synopsis of fractal analysis; good bibliography] 
Beke, C.T., 1847, On the physical character of the table-land of Abyssinia: Report of the Tenth Meeting of the British Association for the Advancement of Science-Notices and abstracts of communications, Geology \& Geography Section, Southhampton, September 1846, v. 15, p. 70-72. [primitive estimates of different regional slopes]

Belgrand, Eugène, 1872, La Seine, études hydrologiques-régime de la pluie, des sources, des eaux courantes, applications à l'agriculture (in French): Paris, Dunod, $>349$ p., accompanying Atlas published 1873. [contains an early hydro-morphometric relation: ratio of watershed area to number of streams within ('drainage density')]

Belisario, Filippo, Del Monte, Maurizio, Fredi, Paola, Funicello, Renato, Lupia Palmieri, E., and Salvini, Francesco, 1999, Azimuthal analysis of stream orientations to define regional tectonic lines: Zeitschrift für Geomorphologie, Supplementband 118, p. 41-63. [rose diagrams \& azimuthal spectra]

Bendick, R., and Bilham, R., 2001, How perfect is the Himalayan arc?: Geology, v. 29, no. 9, p. 791794. [elev./ \& relief/distance distrs. \& least-sq. circle-fitting; plate boundary= small circle of radius $1696 \pm 55 \mathrm{~km}]$

Bengtsson, B.-E., and Nordbeck, Stig, 1964, Construction of isarithmic maps by computers: Nordisk Tidskrift for Informationsbehandling (now 'BIT'), v. 4, no. 2, p. 87-105. [earlest reference to using triangles in computer mapping]

Bergbauer, Stephan, and Pollard, D.D., 1999, Calculating curvatures of geological surfaces (abs.): EOS, Transactions, American Geophysical Union, v. 80, no. 46, Supplement, p. F1050. [based on '1st \& 2nd Fundamental Forms'-quadratic diff. eqns.]

Berger, F., 1805 ca., Hauteurs de plusiers lieux determinées par le barometre, dans le cours de differens voyages faits en France, en Suisse, en Italie (in French): Geneva, privately published, 29 p. [1802-03 barometric determinations of altitudes in Europe by Swiss physician]

Bergsma, E., 1985, Classes of relief susceptibility for surface erosion, in El-Swaify, S.A., Moldenhauer, W.C., and Lo, Andrew, eds., Soil Erosion and Conservation: Ankeny, lowa, Soil Conservation Society of America, p. 432-436. [proposes 4 erosion slope-length classes for 7 slope classes]

Berlyant, A.M., 1984, Morfometricheskiye issledovaniya rel'yefa v SSSR; sostoyaniye, problemy, perspektivy (in Russian; Morphometric investigations of relief in the USSR; present state, problems, perspectives): Geomorfologiya, v. 1984, no. 2, p. 15-24. [25 refs; landform description, quant. geomorph.]

Berlyant, A.M., Koshel', S.M., Musin, O.R., and Suyetova, I.A., 1991, Opyt sozdaniya global'noy tsifrovoy bazy dannykh po gipsometricheskoy karte Mira v masshtabe 1/15 000 000; pervyye rezul'taty (in Russian with English summary; Creation of global digital data base using hypsometric world map scale 1/15M; first results): Geomorfologiya, v. 1991, no. 2, p. 25-31. [DEM's, GIS, morphometry; topo. maps]

Bertolo, Francesca, 2000, Catchment delineation and characterisation-a review: EC-JRC, Space Applications Institute, (EUR 19563 EN) Ispra (VA), Italy, 36 p.; http://ams.egeo.sai.jrc.it/newluc/euroland/pdf/CatchRev.pdf. [the DEM-to-watershed transformation; useful review; good biblio]

Béruber, Dominique, and Jébrak, Michel, 1999, High precision boundary fractal analysis for shape characterization: Computers and Geosciences, v. 25, no. 9, p. 1059-1071. [Euclidean distance mapping (EDM) better than box-counting \& dilation methods; dividers meth. not tested] 
Béthune, P. de, 1967, On the field survey of hillslopes: Revue de Géomorphologie Dynamique, v. 17 , no. 4 , p. 152-153. [favors $10 \mathrm{~m}$ slope-length sampling interval but $15.25 \mathrm{~m} \mathrm{OK}$ ]

Béthune, P. de, and Mammerickx, J., 1960, Études clinométriques du laboratoire géomorphologique de I'Université de Louvain (Belgique), in Birot, P., and Macar, P., eds., Contributions Internationales à la Morphologie des Versants: Zeitschrift für Geomorphologie, Supplementband 1, p. 93-102 \& 2 plates. [1955-59; field \& map data, various areas; freq. diagrams]

Beucher, Serge, 1992, The watershed transformation applied to image segmentation. 1Oth Pfefferkorn Conf. on Signal and Image Processing in Microscopy and Microanalysis, 16-19 sept. 1991, Cambridge, UK, Scanning Microscopy International, Suppl. 6., p. 299-314. $<$ http://cmm.ensmp.fr/ beucher/publi/pfefferkorn.pdf>. [image segmentation by grey scale-toelevation transformation]

Beucher, Serge, 1994, Watershed, hierarchical segmentation and waterfall algorithm, in Serra, J. and Soille, P. eds., Mathematical Morphology and its applications to Image Processing: Dordrecht, Kluwer, p. 69-76. [image segmentation by grey scale-to-elevation transformation]

Beucher, Serge, and Meyer, Fernand, 1992, The morphological approach to segmentation-the watershed transformation, in Dougherty, E., ed., Mathematical Morphology in Image Processing: New York, Marcel Dekker, p. 433-481. [image segmentation by grey scale-to-elevation transform. $\&$ watershed crest-line identification]

Beven, Keith, and Kirkby, M.J., eds., 1993, Channel Network Hydrology: New York, Wiley, 319 p. [10-chapter state-of-art synthesis]

Biasini, Alessandro, Buonasorte, G., Ciccacci, Silvio, Fredi, Paola, and Lupia Palmieri, E., 1993, Geomorphological characteristics, in Di Philippo, M., ed., Sabatini Volcanic Complex: Roma, C.N.R., Quaderni de "La ricerca scientifica" no. 114, v. 11, 2 c. geol., p. 81-94. [local relief \& drainage density]

Biasini, Alessandro, 1997, Estimating relief heights from shadows in vertical aerial photographs: Geologica Romana, v. 33, p. 81-87. [Antarctica (poor parallax \& no topo); shadows v. clear on snow \& ice]

Biasotti, Silvia, 2001, Topological techniques for shape understanding: 10 p., http://www.cg.tuwien.ac.at/studentwork/CESCG-2001/SBiasotti/paper.pdf. [Morse theory, Reeb graphs, height fnc., handles degenerate points]

Bindschadler, Robert, Fahnestock, Mark, and Sigmund, Angela, 1999, Comparison of Greenland ice sheet topography measured by TOPSAR and airborne laser altimetry: IEEE Transactions on Geoscience and Remote Sensing, v. 37, no. 5, p. 2530-2535. [AOL more precise, but TOPSAR covers broader freq. range \& has biases]

Bingham, A.W., and Rees, W.G., 1999, Construction of a high-resolution DEM of and Arctic ice cap using shape-from-shading: International Journal of Remote Sensing, v. 20, no. 15 \& 16, p. 32313242. [photoclinometry of Landsat MSS image; less accurate (14 m RMS) than InSAR]

Bintanja, Richard, Reijmer, C.H., and Hulscher, J.M.H., 2001, Detailed observations of Antarctic blueice surfaces: Journal of Glaciology, v. 47, no. 158, p. 387-396. [regular ripples; troughs spaced 20-24 cm \& crests 1-2 cm deep; crests deeper in summer]

Birnir, Bjorn, Smith, T.R., and Merchant, G.E., 2001, The scaling of fluvial landscapes: Computers and Geosciences, v. 27 , no. 10, p. 1189-1216. ["how models capture effects of random influences driving processes of landscape evolution; account for oval shape of basins \& leads to a derivation of Hack's law"] 
Bishop, M.A., 2001, Seasonal variation of crescentic dune morphology and morphometry, StrzeleckiSimpson desert, Australia: Earth Surface Processes and Landforms: v. 26, no. 7, p. 783-791. [L/W \& vector-mean rose diagrams]

Bishop, M.P., Shroder, J.F. Jr., 2000, Remote sensing and geomorphometric assessment of topographic complexity and erosion dynamics in the Nanga Parbat massif, in Kahn, M.A., Treloar, P.J., Searle, M.P., and Jan, M.Q., eds., Tectonics of the Nanga Prabat Syntaxis and the Western Himalaya: London, Geological Society of London, Special Publication No. 170, p. 181-200. [20-m DEM \& 3-D terrain simulations fr satellite imagery indicate high scale-dependency \& hierarchical order reflecting erosion dynamics]

Bishop, M.P., Bonk, Radoslav, Kamp, Ulrich Jr., and Shroder, J.F. Jr., 2002, Terrain analysis and data modeling for alpine glacier mapping: Polar Geography, v. 25, no. 3, P. 182-201. [successful object-oriented delineation of glaciers by morphometry; 12 elev \& slope attributes fr 20-m DEM; also curvature \& aspect; unsupervised clustering]

Bishop, M.P., Shroder, J.F. Jr., Bonk, Radoslav, and Olsenholler Jeffrey, 2002, Geomorphic change in high mountains-a western Himalayan perspective: Global and Planetary Change, v. 32, no. 4, P. 311-329. [topo analysis fr 20m SPOT DEM incl. elev, A, R, perim., hypso. of 22 basins; other quant.]

Bitelli, G., Carrara, A., and Vittuari, L., 1996, Comparison of DTM's derived from contour lines and digital photogrammetry, in Unguendoli, U., ed., Reports on Surveying and Geodesy, DIS TART, Nautilus, Bologna, p. 159-179. [DTM accuracy from softcopy image correl. not yet fully documented]

Bivand, R.S., 1999, Integrating GRASS 5.0 and R-GIS and modern statistics for data analysis, in Scandinavian Research Conference on Geographical Information Science 7th, Aalborg, Denmark, Proceedings: p. 111-127; http://www.nhh.no/geo/gib/gib1999/gib99-1/scangis.pdf. [topo types, but not regions, of Kosovo fr elev, relief, slope, elev-rel. ratio, plan \& profile curv. on GTOPO30 DEM]

Bivand, R.S., 2000, Using the R statistical data analysis language on GRASS 5.0 GIS database files: Computers and Geosciences, v. 26, no. 9-10, p. 1043-1052;

http://www.nhh.no/geo/gib/gib1999/gib99-2/durham.pdf. [morphometric example has hypsometric integral \& topo types]

Björke, J.T., and Nilsen, Stein, 2002, Efficient representation of digital terrain models-compression and spatial decorrelation techniques: Computers and Geosciences, v. 28, no. 4, p. 433-445. [wavelets slightly better than adapt. triangulation \& univ. kriging, but also have other attractive properties for terrain modeling]

Björnsson, Helgi, Pálsson, Finnur, and Gudmundsson, M.T., 2000, Surface and bedrock topography of the Myrdalsjokull ice cap, Iceland-the Katla caldera, eruption sites and routes of jökulhlaups: Jökull, no. 49, p. 29-46. [100m ice \& subsurface DEMs, ice relief, ice \& topo hypsometric curves]

Black, P.E., 1972, Hydrograph responses to geomorphic model watershed characteristics and precipitation variables: Journal of Hydrology, v. 17, p. 309-329. [planform little effects peak magnitude; defines 'basin-eccentricity' param.]

Blackwell, P.R., and Wells, Gordon, 1999, DEM resolution and improved surface representation: ESRI 1999 User Conference, San Diego, CA, Proceedings; www.esri.com/library/userconf/proc99/proceed/abstracts/a629.htm. [10m DEMs, esp. with drainage enforcement, better for geomorphic analysis than $30 \mathrm{~m}$.]

Blenk, M., 1963, Eine kartographische Methode der Hanganalyse, erläutert an zwei Beispielen-N.W.-Harz und Salinstal, Kalifornien ('... slope analysis ...', in German), in Neue 
Beiträge zur internationalen Hangforschung: Göttingen, Vandenhœck und Ruprecht, p. 29-44. [get angle of crests, valley floors \& plan-curved slopes fr contour maps]

Bliss, N.B. and Olsen, L.M., 1998, Development of a 30 arc-second digital elevation model of South America, in Pecora Thirteen, Human Interactions with the Environment-Perspectives from Space, 13th, Sioux Falls, SD, August 20-22, 1996, Proceedings: Bethesda, MD, American Society of Photogrammetry and Remote Sensing, CD-ROM; also <http://edcwww.cr.usgs.gov/landdaac/gtopo30/papers/olsen.html>. [GTOPO30 DEM]

Blong, R.J., 1972, Methods of slope profile measurement in the field: Australian Geographical Studies, v. 10 , no. 2 , p. $182-192$. [details methods for fine-scale survey; $1.5 \mathrm{~m}=$ min. practical length; good biblio]

Blong R.J., 1985, Gully sidewall development in New South Wales, Australia, in El-Swaify, S.A., Moldenhauer, W.C., and Lo, Andrew, eds., Soil Erosion and Conservation: Ankeny, lowa, Soil Conservation Society of America, p. 574-584. [field meas. of gully cross-section, to get sidewall surface-area ratio, volume]

Blow, Jonathan, 2000, Terrain rendering at high levels of detail, in Game Developers Conference 2000, 20-24 March, San Jose Conference Center, San Jose, CA, Proceedings: 1st online article, 13 PDF pages + his lecture notes for Two Advanced Terrain Rendering Systems (4 p.); $<$ http://www.bolt-action.com/dl_papers.html>. [state-of-art; modifications improve the ROAM triangulation (a 'top-down' algorithm rather than Lindstrom et al's. 1996 less efficient 'bottom-up' procedure) to handle high levels of texture detail in a scalable way]

Blunt, Liam, and Stout, K.J., eds., 2001, International Conference on Metrology and Properties of Engineering Surfaces, 8th, 26-29 April, 2000, Huddersfield, UK, Proceedings: International Journal of Machine Tools and Manufacture, v. 41, Nos. 13-14, p. 1847-2193. [38 papers on topology, contact mech., instrumentation, eng. sfcs., meas. \& calibr., \& charac. \& filtering]

Bobrik, A.A., 1916, On the calculation of the 'Küstenentwicklung' or shore-line convolution according to the Berghaus and Nagel methods (in Russian): Izvestiya Russkogo geograficheskogo obshchestva, v. 52, no. 1. [early Russian morphometry addressing the 19th-Century area/perimeter problem]

Bochet, E., Poesen, J., and Rubio, J.L., 2000, Mound development as an interaction of individual plants with soil, water erosion and sedimentation processes on slopes: Earth Surface Processes and Landforms: v. 25, no. 8, p. 847-867. [slope \& mound height fr. quant. height $( \pm \mathrm{mm})$ profiles fr. microprofilometer]

Böhm, August, 1887, Einteilung der Ostalpen (in German), in Penck, Albrecht, ed., Geographische Abhandlungen: Vienna, E. Hölzel, v. 1, no. 3, p. 243-478. [contains morphometry; no other info]

Böhm, August, 1887, Über Gerbirgsgruppierung (in German; on classification of mountain ranges), in Verhandlung des 7 Deutschen Geographentages zu Karlsruhe: Berlin, Reimer, p. 152-158. [a morphologic objective that affected the morphometry of the time; no other info]

Böhm, August, 1889, Über die Genauigkeit der Bestimmung von Gerbirgsvolumen und mittleter Massenerhebung (in German; On accuracy of obtaining mountain volume \& center of mass), in Verhandlung des 8 Deutschen Geographentages zu Berlin: Berlin, Reimer, p. 214-224. [a concern of morphometry at the time; no other info]

Böhmer, Gerhard, 1922, Die Flußdichte im Gebiete der mecklenburgischen Seenplatte und ihrer Vorländer; Ein Beitrag zur Heimatkunde (in German; drainage density ...), Univ. Rostock, Ph.D. dissertation: Teterow, Germany, 16 p. [methods of Rasehorn 1911 \& Neumann 1900; pamphlet undated \& no maps, tables, or refs] 
Bohner, Jürgen, Köthe, Rüdiger, and Trachinow, Christian, 1997, Weiterentwicklung der automatischen Reliefanalyse auf der Basis von Digitalen Reliefmodellen (Advancing automatic relief analysis by means of digital relief models): Göttinger Geographische Abhandlungen, v. 100, p. 321. [post-SARA development of Köthe's morphometric pkg.]

Bonk, Radoslav, 2002, Scale-dependent Geomorphometric Analysis for Glacier Mapping at Nanga Parbat, Pakistan: Master's thesis, Department of Geography-Geology, College of Arts and Sciences, University of Nebraska at Omaha, paging unknown. [TFO (terrain form objects) fr slope, aspect, plan. \& profile curv. fr 20-m DEM / details]

Bonk, Radoslav, 2002, Scale-dependent geomorphometric analysis for glacier mapping at Nanga Parbat-GRASS GIS approach, in Open source GIS-GRASS users conference 2002, Trento, Italy, 11-13 September, Proceedings: paging unknown; http://dionysos.gssr.sk/ig_home/exchange/ppaudits/trento2002_bonk.pdf. [TFO (terrain form objects) fr slope, aspect, plan. \& profile curv. fr 20-m DEM]

Bonniard, F., 1929, Représentation graphique de la pente moyenne d'un bassin-versant (in French): Revue Phys. Géographie Dynamique, v. 2, p. 247-252. [1st publ.? method for clinographic curve, or mean slope betw. paired contours]

Borsuk, O.A., 1989, Morfometriya rel'yefa; indikatsionnoye i geneticheskoye napravleniya (in Russian; indicative \& genetic morphometry of relief), in Logachev, N.A., Timofeyev, D.A., and Ufimtsev, G.F., ed., Problemy metodologii geomorfologii (Methodology problems in geomorphology): Novosibirsk, Izd. Nauka, p. 37-40. [corr. coeff., indicators, relief, statistical analysis]

Böttcher, Herr, 1900, Maß für die Dichte der Eisenbahnnetze (index of railroad network density; in German): Geographische Zeitschrift, v. 4, p. 635-639. [adapted to drainage density; $x=2 A / L ; P$ $=$ unit-cell area $\& \mathrm{~L}=$ total length]

Boussinesq, J.V., 1871, Sur une propiété remarquable des points où les lignes de plus grande pente d'une surface ont leurs plans osculateurs verticaux, est sur la différence qui existe généralement, à la surface de la terre, entre les lignes de faîte ou de thalweg et celles le long desquelles la pente du sol est un minimum (in French; ... a remarkable property of points where the steepest slope lines have vertical osculatory plans (?), is about the difference which generally exists on the ground surface between ridges or drain lines \& locations where ground slope is a minimum.): Comptes Rendus Hebdomadaires des Séances de l'Académie des Sciences, v. 73, no. 24, p. 1368-1371. [hydrodynamicist \& Saint-Venant pupil; noted that Saint-Venant's 1852 math. formulation of topo. ridges \& drains had not specified slope-lines (slope = zero) that form drainage pattern itself]

Boussinesq, J.V., 1872a, Sur les lignes de faîte et de thalweg (in French; on ridge \& drainage lines): Comptes Rendus Hebdomadaires des Séances de l'Académie des Sciences, v. 73, p. 198-201. [see Boussinesq 1871]

Boussinesq, J.V., 1872b, Sur les lignes de faîte et de thalweg (in French; on ridge \& drainage lines): Comptes Rendus Hebdomadaires des Séances de l'Académie des Sciences, v. 75, no. 15, p. 835837. [criticizes Jordan 1872a; see note for Boussinesq 1871]

Bovis, M.J., and Jakob, Matthias, 1999, The role of debris supply conditions in predicting debris flow activity: Earth Surface Processes and Landforms, v. 24, no. 11, p. 1039-1054. [33 basins; pred. d-f attributes fr. basin morphometry by mult. regression]

Bowler, P.J., 2002, Climb Chimborazo and see the world: Science, v. 298, no. 5591, p. 63-64. [briefly reviews work of A. von Humboldt (1769-1859), citing 'passion for precise description \& accurate measurement', interest in the 'structure of mountains' \& 'techniques of geodetic and geophysical measurement', and preparation of 'the first relief map of Spain'] 
Boyell, R.L., and Rushton, H., 1963, Hybrid techniques for real-time radar simulation, in Fall 1963 Joint Computer Conference, November, Las Vegas NV, Proceedings: paging unknown. [1st to map contours into arcs \& intercontour areas into nodes]

Boyko, A.V., and Limontov, L.Ya., 1980, Digital terrain models and topographic data collection in large-scale mapping (in Russian): Geodesiya i Cartographiya, no. 10, p. 46-53. [no info]

Brabyn, L.K., 1996, Landscape classification using GIS and national digital databases: Christchurch NZ, University of Canterbury, Department of Geography, unpublished Ph.D. thesis, 225 p. + refs. ['classif. visual landscape character'; esp. p. 124-150 automates, modifies Hammond system; 200m DEM fr $1 / 250 \mathrm{~K}$ map]

Brabyn, L.K., 1997, Classification of macro landforms using GIS: ITC Journal, no. 1, p. 26-40. [automates, modifies Hammond system; 1/250K DEM (200-m grid)]

Brändli, Martin, 1998, Modelle und Algorithm für Extraktion geomorphologischer und hydrologischer Objekte aus digitalen Geländemodellen (in German): Geographisches Institut Universität Zürich, Geoprocessing Reihe, v. 32 (Inaugural dissertation), 200 p. + appendices. [continuaton of prior work extracting catchments etc. from DEM's]

Brasington, James, and Richards, Keith, 1998, Interactions between model predictions, parameters and DTM scales for TOPMODEL: Computers and Geosciences, v. 24, no. 4, p. 299-314. [depends much on grid size DL $(20 \mathrm{~m} \leq \mathrm{DL} \leq 500 \mathrm{~m})$, esp. @ 100m-200m threshold]

Brassard, Louis, 1998, The Perception of the Image World: Burnaby, BC, Simon Fraser University, unpublished Ph.D. thesis, 409 p. http://www.visionlb.ca/Thesis/Abstract.html. [far-ranging treatise by a computer-vision engineer, focusing on crease detection in greyscale images (among 'creases' are such critical points \& lines as peaks, pits, ridges, valleys, saddles, passes)]

Braun, Jean, Zwartz, Dan, and Tomkin, J.H., 1999, A new surface-processes model combining glacial and fluvial erosion: Annals of Glaciology, v. 28, p. 282-290. [exper. results fr CASCADE algorithm modified to include glaciation]

Breton de Champ, Paul-Émile, 1854, Note sur les lignes de faîte ou de thalweg (in French; ... ridges and drains): Comptes Rendus Hebdomadaires des Séances de l'Académie des Sciences / Institut de France, v. 39, p. 647-648. [noted that (Saint-Venant's 1852 implied) math. formulation of topo. ridges \& drains had not specified exactly the slope-lines that form the drainage pattern; offered new theorem]

Breton de Champ, Paul-Émile, 1861, Note sur les charactères géométriques des lignes de faîte ou de thalweg (in French; ... geometric char. of ridges or drains): Comptes Rendus Hebdomadaires des Séances de l'Académie des Sciences / Institut de France, v. 53, p. 808-811. [elaboration on ideas in 1854 paper]

Breton de Champ, Paul-Émile, 1867, Note sur une propriété de l'équation différentielle des lignes de plus grande pente (in French; ... prop. of diff. eqn. of flow lines): Comptes Rendus Hebdomadaires des Séances de l'Académie des Sciences / Institut de France, v. 64, p. 407-410. [eqn. describes flow lines, slope lines normal to contours]

Breton de Champ, Paul-Émile, 1870, Sur les lignes de plus grande pente à déclivité minimum ou maximum (in French; on flow lines of minimum or maximum steepness): Comptes Rendus Hebdomadaires des Séances de l'Académie des Sciences / Institut de France, v. 70, no. 18, p. 982-985. [no info]

Breton de Champ, Paul-Émile, 1877, Mémoire sur les lignes de faîte et thalweg que l'on est conduit à considérer en topographie (in French; ... on drain and ridge lines that must be addressed in topo.): 
Journal de Mathématiques Pures et Appliquées, ser. 3, v. 3, p. 99-114. [extends descriptivegeometric description of ridges \& drains; poses 5 problems]

Breuer, Barbara, 2001, Reliefmodellierung mit dem Programm SARA (System zur Automatischen Relief-Analyse) für ein Untersuchungsgebiet in der Oberpalz (in German): Zeitschrift für Geomorphologie, v. 45, no. 1, p. 17-31. [elev. \& slope maps, etc. fr DEM]

Breunig, M., 1999, An approach to the integration of spatial data and systems for a 3D geoinformation system: Computers and Geosciences, v. 25, no. 1, p. 39-48. [theory \& basics of 3D modeling; topology]

Breusing, Dr., 1882, comments (in German) in Günther (1882), p. $146 . \quad$ [the area/perimeter problem]

Bribiesca, Ernesto, 1988, Digital elevation model data analysis using the contact surface area: CUGIP - Graphical Models and Image Processing, v. 60, no. 2, p. 166-172. [computer graphics, A.I., simulation, \& modeling]

Brice, J.C., 1966, Erosion and deposition in the loess-mantled Great Plains Medicine Creek drainage basin, Nebraska: U.S. Geological Survey, Professional Paper 352-H, p. 255-339. [\% upland, freq. 1 st-order channels, relief ratio, areal freq. of valley-head $\&$-side gullies]

Brimicombe, A.J., and Tsui, P.H.Y., 2000, A variable resolution, geocomputational approach to the analysis of point patterns: Hydrological Processes, v. 14, nos. 11-12, p. 2143-2155. [compared to nearest-neighbor, quadrat, \& L-function approaches]

Brisson, Barnabé, 1829, Un essai sur l'art de projeter les canaux à point de partage par MM. Dupuis de Torcy et $\mathrm{B}$. Brisson (on planning canals à point de partage (those linking different drainage basins) ... ; in French), in Essai sur le système général de navigation intérieure de la France (On the General System of France's Inland Navigation): Carilian-Goeury, Paris (172 p.), paging of essay unknown. $\quad$ [posthumous re-publ. of Dupuis-Torcy \& Brisson 1808 under more explicit title, by Duleau, who edited book \& contributed a long intro.; Brisson was a geometer \& civil engineer (1777-1828) \& student of Gaspard Monge ('father of differential geometry' \& 1st to describe lines on curved 3-D surfaces); Brisson applied descriptive geometry to canal engineering \& thus improve its cost estimates]

Brock, J.C., Wright, C.W., Sallenger, A.H., Krabill, W.B., and Swift, R.N., 2002, Basin and methods of NASA Airborne Topographic Mapper LiDAR surveys for coastal srudies: Journal of Coastal Research, v. 18, no. 1, p. 1-13. [good overview of LiDAR measurement in low-relief terrain]

Brodley, C.E., Lane, Terran, and Stough, T.M., 1999, Knowledge discovery and data mining: American Scientist, v. 87, no. 1, p. 54-61. [improved automated technique for finding small volcanoes on Venus]

Bronstert, Axel, 1999, Capabilities and limitations of detailed hillslope hydrological modelling: Hydrological Processes, v. 13, no. 1, p. 21-48. [uses HILLFLOW; review; soils \& climate data needed for best results, etc.]

Brooks, S.M., and McDonnell, R.A., eds., 2000, Geocomputation in Hydrology and Geomorphology: Hydrological Processes, v. 14, nos. 11-12, p. 1899-2206. [7 of the papers deal with some aspect of DEM-based geomorphometry]

Brown, C.A., Charles, P.D., and Johnsen, W.A., 1994, Method for quantifying the topographic structure of a surface: U.S. patent 5,307,292. [fractal analysis by their TIN 'patchwork' method]

Brown, D.G., 1994, Anisotropy in elevation and derivative surfaces as an indication of systematic errors in DEMs, in Congalton, R.G., ed., International Symposium on the Spatial Accuracy of 
Natural Resource Data Bases, Williamsburg, VA, American Society for Photogrammetry and Remote Sensing, Proceedings: p. 98-107. [no info]

Brown, D.G., and Olson, J.M., 2001, Integrated teaching of geographic information science and physical geography through digital terrain analysis: Journal of Geography, v. 100, no. 1, p. 4-13. [DEM-based pedagogy emphasizing technology]

Brown, D.R., and Owen, D.H., 1967, The metrics of visual form-methodological dyspepsia: Psychological Bulletin, v. 68, p. 243ff. [caveat: 12 linear factors explain $87 \%$ variance in shape measures for random sample of quadrilaterals, despite object space having only 4 geometric degrees of freedom!]

Brown, E.H., 1950, Erosion surfaces in north Cardiganshire: Transactions and Papers of the Institute of British Geographers, no. 16, p. 51-66. [modified the height-range diagram of Sparks 1949]

Brown, E.H., 1952, The River Ystwyth, Cardiganshire-A geomorphological analysis: Proceedings of the Geologists' Association, v. 63, no. 3, p. 244-269. [modified height-range diagram (Sparks 1950); longit. profile]

Brown, S.R., 1995, Measuring the dimension of self-affine fractals-examples of rough surfaces, in Barton, C.C., and LaPointe, P.R., 1995, eds., Fractals in the Earth Sciences: NY \& London, Plenum, p. 77-87. [presents methods for computation]

Bruce, R.C., 1971, A study of the relationship between soil and quantitative terrain factors: Honolulu, University of Hawaii, unpublished Ph.D. dissertation, 202 p. [no info]

Brunsden, Denys, 1973, The application of systems theory to the study of mass-movement: Geologica Applicata e Idrogeologia (Univ. Bari, IT): v. 8, no. 1, p. 185-207. [proposes 20 geometric quantities for landslide mass \& scar \& enclosing hillside, after Varnes 1958 terminology]

Brunsden, Denys, ed., 1971, Slopes, Form and Process: Institute of British Geographers Special Publication no. 3, 178 p. [11 papers fr. British Geomorphological Research Group; emph. slope profiles, soils]

Brunsden, Denys, 1984, Mudslides, chap. 9 in Brunsden, Denys, and Prior, D.B., eds., Slope Instability: London, Wiley, p. 363-418. [obs. on approx. geometries of mudslide source, track, \& accumulation zone]

Brunson, E.B., and Olsen, R.W., 1978, Data digital elevation model collection systems, in Digital Terrain Models (DTM) Symposium, May 9-11, St. Louis, MO, American Society of Photogrammetry, Proceedings: p. 72-99. [explains origin of striped artifacts in USGS manually-profiled DEMs]

Bruun, Bjørn, and Nilsen, Stein, 2001, Multiscale representation of terrain models using average interpolating wavelets, in ScanGIS'2001, Scandinavian Research Conference on Geographical Information Science 8th, Ås, Norway, 25-27 June, Proceedings: p. 33-44;

<http://www.nlh.no/conf/scangis2001/papers/20.pdf>. [rapidly partitions large DEMs to construct hierarchical DEMs]

Bucknarn, R.C., Coe, J.A., Chavarria, M.M., Godt, J.W., Tarr, A.C., Bradley, L.-A., Rafferty, S.A., Hancock, Dean, Dart, R.L., and Johnson, M.L., 2001, Landslide susceptibility mapping on the Pueblo Viejo and Río Hondo Quadrangles, in Landslides triggered by Hurricane Mitch in Guatemala; inventory and discussion: U.S. Geological Survey Open-file Report 01-0443, p. 26-33, http://greenwood.cr.usgs.gov/pub/open-file-reports/ofr-01-0443/. [map from spatial freq. of elev, slope, and landslides; aspect \& plan curv. not signif.] 
Budd, W.F., Jenssen, D., and Smith, I.N., 1984, A three-dimensional time-dependent model of the Antarctic ice sheet: Annals of Glaciology, v. 5, p. 29-36. [1st Ant. DEM; constr. fr. digitized 1/6M map; $20 \mathrm{~m}$ resolution]

Bull, W.B., 1964, Geomorphology of segmented alluvial fans in western Fresno County, California: U.S. Geological Survey Professional Paper 353-E, p. 89-129. [earliest? power functions relating fan area to that of drainage basin]

Bull, W.B., 1964, Alluvial fans and near-surface subsidence in western Fresno County, California: U.S. Geological Survey Professional Paper 437-A, 71 p. [relief/area, \% area/altitude (little variance for 3 fan types), slope]

Bull, W.B., 1968, AlluviaL Fans: Jouirnal of Geological Education, v. 16, no. 3, p. 101-106. [reviews quant. aspects; area, slope, Troeh eqn.]

Bull, W.B., 1975, Landforms that do not tend toward a steady state, in Melhorn, W.N., and Flemal, R.C., eds., Theories of Landform Development, annual geomorphology symposium, 6th, 26-27 September, Proceedings: Binghamton, N.Y., SUNY, Publications in Geomorphology, p. 111-128. [allometric fcn. useful for such forms, esp. erosional, incl. cliffs]

Bulmer, M.H., and Wilson, J.B., 1999, Comparison of flat-topped stellate seamounts on Earth's seafloor with stellate domes on Venus using side-scan sonar and Magellan synthetic aperture radar: Earth and Planetary Science Letters, v. 171, no. 2, p. 277-287. [log-log height/diam.; domes large; cf Kreslavsky \& Head; some clusters, much scatter]

Bülow, Kurd von, Kranz, Walter, and Sonne, Erich, 1938, Wehrgeologie (in German; with revisions by Prof. Dr. Otto Burre \& Prof. Dr. Wilhelm Dienemann): Leipzig, Quelle \& Meyer, 178 p. [the German classic on military geology, incl. terrain intelligence \& appreciation]

Burbank, D.W., and Anderson, R.S., 2001, Tectonic Geomorphology: Malden, MA, and Abingdon, UK, Blackwell Science, 274 p. [Ch. 10 \& 11 address DEM applics. \& landscape-evolution modeling]

Burgkhardt, Johannes, 1888, Das Erzgebirge, eine orometrisch-anthropogeographische Studie: Stuttgart, Engelhorn, Forschungen zur deutschen Landes- und Volkskunde, v. 3, no. 3, p. 84-159. [a 79 p. thesis (Leipzig, 1890)?; relates population, etc. to terrain measures; mean elev., ridge height, area, vol.]

Burl, M.C., Fayyad, U.M., Perona, Pietro, Smyth, Padhraic, and Burl, M.P., 1994, Automating the hunt for volcanoes on Venus, in 1994 Computer Vision and Pattern Recognition Conference (CVPR-94), Seattle WA, June, Proceedings: Los Alamitos CA, IEEE Computer Society Press, p. 302-309. [multi-tiered data mining the Magellan images for small edifices]

Burnett, A.D., Brand, E.W., and Styles, K.A., 1985, Terrain classification mapping for a landslide inventory in Hong Kong, in International Conference abnd Field Workshop on Landslides, 4th, 2331 August, Tokyo, Proceedings: The Japan Landslide Society, p. 63-68. [slope angle, height \& morphology, length/width, landform, hydrology, erosion type; no. freq. by slope \& geology]

Burrough, P.A., and McDonnell, R.A., 1998, Principles of geographical information systems for land resources assessment, 2nd ed. (corrected reprinting, 1998): New York, Oxford Press, 333 p. [standard text; $150 \mathrm{pp}$. longer than 1st ed.]

Butler, J.B., Lane, S.N., and Chandler, J.H., 2001, Characterization of the structure of river-bed gravels using two-dimensional fractal analysis: Mathematical Geology, v. 33, no. 3, p. 301-330. [semivariograms (\& their contoured surfaces) fr hi-res. digital photogramm. DEMs] 
Cabrol, N.A., and Grin, E.A., 2001, Composition of the drainage network on early Mars:

Geomorphology, v. 37, nos. 3-4, p. 269-287. [n=71; modified Horton ordering \& 12 params.;

stream nos., A, 'compacity', etc.]

Cacheiro Pose, M., Valcarcel Armesto, M., Vieira, S.R., and Toboada Castro, M.T., 1998, Elaboración de modelos de elevación digital empleando técnicas geoestadísticas y sistemas de información geográfica (Using geostatistics and GIS for DTM assessment, in Spanish): Cadernos do Laboratorio Xeolóxico de Laxe (Univ. Coruña), v. 23, p. 137-150. [an exercise in applying a number of techniques to cultivated fields]

Cailleux, André, 1947, Caractères distinctifs des coulées de blocailles liées au gel intense (in French; dist. char. of blocky ravines related to intense freezing): Comptes Rendue Sommaire de la Société Géologique de France, 15 Dec., p. 323-324. [slope measurements; early postwar example of French morphometry]

Caine, Nel, 1982, Toppling failures from alpine cliffs on Ben Lomond, Tasmania: Earth Surface Processes and Landforms, v. 7, no. 2, p. 133-152. [LT/LC ratio critical; respective distances $=\mathrm{fr}$ top of topple (LT) \& cliff (LC) to base of cliff where it meets topple]

Caine, Nel, 1983, The Mountains of Northeastern Tasmania: Rotterdam, Balkema, 200 p. [var. morphometry; valley width/distance, solution-pan W/D, cliff profiles \& PSD, cliff ratio/mt. elev., blockfield size \& orientattion \& slope/distance]

Calvet, Marc, Carozza, J.-M., and Delcaillau, Bernard, 2000, Du bon usage de la morphometrie; a propos de Reponse des bassins versants a l'active tectonique; l'exemple de la terminaison orientale de la chaine pyreneenne; approche morphotectonique (in French; on proper use of morphometry; re Response of drainage basins to active tectonics; example from the eastern Pyrenees; morphotectonic approach; discussion and reply: Geomorphologie, v. 2000, no. 4, p. 267-274. [no info; neo-orometry?]

Campbell, R.H., and Chirico, Peter, 1999, Geographic information system (GIS) procedure for preliminary delineation of debris-flow hazard areas from a digital terrain model, Madison County, Virginia: U.S. Geological Survey, Open-file Report 99-336, 25 p. $\quad$ [user-specified input = depth of d-f surge rather than its initial volume]

Canters, Frank, De Genst, William, and Dufourmont, Hans, 2002, Assessing effects of input uncertainty in structural landscape classification: International Journal of Geographical Information Science, v. 16, no. 2, p. 129-149. [DEM \& classif. error; 4 indices incl. field-of-view 'shape' complexity]

Caputo, C., Del Monte, M., Fredi, Paola, Plamieri, E.L., and Pugliese, F., 1995, The volcano of the Alban Hills-geomorphological features, in Trigila, Raffaello, ed., The Volcano of the Alban Hills: Roma, Tipografia SGS, p. 13-32. [local relief \& drainage density mapped]

Carlberg, Berthold, 1942, Morphographische und physiographische Karte. zur kleinmaßstäbigen Geländedarstellung (in German): Petermanns Geographische Mitteilungen, v. 88, no. 5, p. 193195. [small-scale repr. of physiography; cites Tanaka, H. Lehmann, Raisz]

Carling, P.A., Gölz, E., Orr, H.G., and Radecki-Pawlik, A., 2000, The morphodynamics of fluvial sand dunes in the River Rhine, near Mainz, Germany. I Sedimentology and morphology: Sedimentology, v. 47, no. 1, p. 227-252. [height/length, lee \& stoss slopes \& lengths, flatness index]

Carn, S.A., 2000, The Lamongan volcanic field, East Java, Indonesia-physical volcanology, historic activity and hazards: Journal of Volcanology and Geothermal Research, v. 95, nos. 1-4, p. 81-108. [morphometry for 22 maars \& 37 cinder/spatter cones] 
Carniel, P., and Schiedegger, A.E., 1974, Morphometry of an Alpine scree cone (in Italian): Rivista Italia Geofisica, v. 23, p. 95-100. [measured profiles of talus slopes]

Carrara, Alberto, Bitelli, G., and Carla', R., 1997, Comparison of techniques for generating digital terrain models from contour lines: International Journal of Geographic Information Science, v. 11, no. 5, p. 451-473. [set out Q/A criteria: most techniques fail on at least one; ArcTin not so good]

Carrara, Alberto, Cardinali, Mauro, Detti, Riccardo, Guzzetti, Fausto, Pasqui, Valdo, and Reichenbach, Paola, 1990, Geographical information systems and multivariate models in landslide hazard evaluation, in Cancelli, Andrea, ed., ALPS 90, Alpine Landslide Practical Seminar (6th Int'l. Conf. \& Field Workshop on Landslides, Switz.-Austr.-Italy), August 31-September 12, Milano, IT, Proceedings: p. 17-28. [4-part hazard eval. for Tescio basin, Umbria; see also same authors, 1991]

Carroll, Damian, and Morse, Michael, 1996, A national digital elevation model for resource and environmental management: Cartography (Canberra), v. 25, no. 2, p. 43-49. [GEODATA 9second DEM of Australia]

Carson, T.M., 1996, Texture-based terrain classification and optimal sampling in support of digital elevation model extraction: West Lafayette, IN, Purdue University, unpublished Ph.D. dissertation, 257 p. [no info]

Carter, W.E., Shrestha, R.L., Tuell, Grady, Bloomquist, David, and Sartori, M., 2001, Airborne laser swath mapping shines new light on Earth's topography: EOS, Transactions, American Geophysical Union, v. 82, no. 46, p. 549-550, 555. [intro to LIDAR; specs, processing, applics; landslide mapping]

Centamore, E., Ciccacci, Sirio, Del Monte, Maurizio, Fredi, Paola, and Lupia Palmieri, E., 1996, Morphological and morphometric approach to the study of structural arrangement of northeastern Abruzzo (central Italy): Geomorphology, v. 16, no. 2, p. 127-137. [map of relative relief \& stream rose diagrams]

Cerny, J.W., 1975, Sensitivity analysis of the Boyce-Clark shape index: The Canadian Cartographer, v. 12 , no. 1 , p. 21-27. [needs procedural consistency $\&>16$ radials]

Chakraborty, B., Schenke, H.W., Kodagali, V., and Hagen, R., 2001, Analysis of multibeamHydrosweep echo peaks for seabed characterisation: Geo-Marine Letters, v. 20, no. 3, p. 174-181. [roughness from PSD functions]

Chan, D., 1992, Fractal geometry and its geomorphologic meanings for Taiwan (in Chinese): Tainan, National Cheng Kung University, Department of Earth Sciences, M.Sc. thesis, 103 p. [variogram method for self-affine D]

Chandler, R.J., 1973, The inclination of talus, Arctic talus terraces, and other slopes compoised of granular materials: Journal of Geology, v. 81, no. 1, p. 1-14. [field profiles $+1960-71$ histograms \& 1903-70 slope means fr older obs.]

Chang, K.-T., and Li, Zhaoxing, 2000, Modelling snow accumulation with a geographic information system: International Journal of Geographical Information Science, v. 14, no. 7, p. 693-707. [get 'snow water equivalent' fr location \& topo variables fr USGS 3" DEM]

Chang, S.-C., 1992, The Simprecise mapping and evaluation system for engineering geological and landslide hazard zonation, in Bell, D.H., ed., Landslides, International Symposium 6th, 10-14 February, Christchurch NZ, Proceedings: Rotterdam, Balkema, v. 2, p. 905-910. [no DEM; terrain facets; variables include slope type \& angle] 
Chao, P.W., 1995, Landform simulation and the fractal properties of the topography of Taiwan (in Chinese): Tainan, National Cheng Kung University, Department of Earth Sciences, M.Sc. thesis, 100 p. [variogram method for self-affine D]

Chaplot, V., Walter, C., and Curmi, P., 1999, Sensitivity of a quantitative soil-landscape model to the precision of the topographical input parameters, Ch. 10 in Lowell, Kim, and Jaton, Annick, eds., Spatial Accuracy Assessment-Land Information Uncertainty in Natural Resources: Chelsea, MI, Ann Arbor Press, p. 89-95. [DEM needs $<20 \mathrm{~m}$ spacing + hi-info-content supplementary elevs.]

Chappelow, J.E., Kieniewicz, J.M., and Sharpton, V.L., 2000, Calculation of crater depths from shadows of arbitrary width (abs.): Eos Transactions of the American Geophysical Union, v. 81, no. 48 (Supplement, P11A-19), p. F803. [by assuming simple crater shape = parabola, shadow need not be at center]

Charleux-Demargne, Julie, and Puech, Christian, 2000, Quality assessment for drainage networks and watershed boundaries extraction from a digital elevation model (DEM), in Li, K.-J., Makki, Kia, Pissinou, Niki, and Ravada, Siva, Eds., ACM-GIS 2000, ACM Symposium on Advances in Geographic Information Systems 8th, 10-11 Nov., Washington D.C.: Proceedings, p. 89-94. [see 2001 citation]

Charleux-Demargne, Julie, 2001, Qualité des Modèles Numériques de Terrain pour l'hydrologie, Application à la caractérisation du régime de crues des bassins versants (in French with English abstract): Thèse Univ. Marne-La-Vallée (France), Sciences de I'Information Géographique, 350 p., http://www.montpellier.cemagref.fr/doc/publications/theses/julie-charleux-demargne.html. [probabl. repr. network \& watersheds to find bias of DEM orientation = f (DTM \& terrain); eval. assess impact of DEM repairs]

Chartrand, S.M., and Whiting, P.J., 2000, Alluvial achitecture in headwater streams with special emphasis on step-pool topography: Earth Surface Processes and Landforms, v. 25, no. 6, p. 583600. [channel-bed step L, H, W, slope, \& scour-depth]

Cheng, A.F., and 11 others, 2001, Laser altimetry of small-scale features on 433 Eros from NEARShoemaker: Science, v. 292, no. 5516, p. 488-491. [1.0m resolution; 1 crater profiled; fractal analysis of terrain profiles]

Cheng, Qiuming, 1999, Multifractality and spatial statistics: Computers and Geosciences, v. 25, no. 9, p. 949-961. [lacunarity \& semivariance for patterns on bands from 6 Landsat TM images]

Cheng, Qiuming, Russel, H., Sharpe, D., Kenny, Frank, and Qin, Ping, 2001, GIS-based statistical and fractal/multifractal analysis of surface stream patterns in the Oak Ridges Moraine: Computers and Geosciences, v. 27 , no. 5 , p. 513-526. [stream L, no., bifurc. ratio, density, R, slope, \& basin perim. \& A for 322 basins]

Cheng, Y.C., Lee, P.J., and Lee, T.Y., 1999, Self-similarity of the Taiwan Island landscape: Computers and Geosciences, v. 25, no. 9, p. 1043-1050. [40 m DEM; 3-D box-count fractal D > $\mathrm{w} /$ elev. < 1000m; gets $D$ for regions]

Chentsov, V.N., 1940, Morphometric attributes of relief as applied to geomorphological maps (in Russian?), in Grigoryev, A.A., ed., Transactions of the Institute of Geography, no. 36: Soviet Academic Press, Moscow, p. 69-71. [no info]

Chertkov, V.Y., and Ravina, I., 1999, Tortuosity of crack networks in swelling clay soils: Soil Science Society of America Journal, v. 63, no. 6, p. 1523-1530. [2-D network char. tort. (connectedness) \& spacing of cracks]

Childs, John, 2002, Terrain modeling and mapping using DEM, SDTS, DRG, DLG and DTED Data: Digital Terrain Modeling and Mapping; http://www.terrainmap.com/index.html\#top. [excellent 
hands-on info for DTM, emphasizing "data sources, general technique (as opposed to specific applications), \& ... demystification ..." jchilds@terrainmap.com]

Chin, Anne, 1999, The morphologic structure of step-pools in mountain streams: Geomorphology, v. 27 , nos. 3-4, p. 191-204. [n=464; height \& spacing $\approx$ particle size \& discharge, resp., not slope directly]

Cholnoky, Jenö, 1902, A futóhomok mozgásának törvényei (in Hungarian): Földtani Közlöny (J. Hung. Geol. Soc., Budapest), v. 69, no. 32, p. 6-38. [topo maps \& sections of barchan dunes; refs. Hedin \& Cornish]

Chorley, R.J., 2000, Classics in physical geography revisited-'Mackin, J.H., 1948, Concept of the graded river: Geological Society of America Bulletin, 59, p. 463-511': Progress in Physical Geography, v. 24, no. 4, p. 563-578. [explains why Mackin's qualitative explication is essential to understanding subsequent quant. developments]

Chorowicz, Jean, Rouis, T., Rudant, J.-P., and Manoussis, S., 1998, Computer aided recognition of relief patterns on radar images using a syntax analysis: Remote Sensing of the Environment, v. 64, no. 3, p. 221-233. [x-band $(3,2 \mathrm{~cm}), 2 \mathrm{~m} \times 2 \mathrm{~m}$ pixels, reqd. much filtering \& processing]

Chou, Y.-H., Dezzani, R.J., Minnich, R.A,. and Chase, R.A., 1995, Correction of surface area using digital elevation models: Geographical Systems, v. 2, p. 131-151. [for both planimetric maps \& scanned images]

Chou, Y.-H., Liu, P.-S., and Dezzani, R.J., 1999, Terrain complexity and reduction of topographic data: Journal of Geographical Systems (Springer), v. 1, p. 179-198. [meas. terrain complexity to reduce data redundancy $\&$ applies to two $30-\mathrm{m}$ DEMs]

Christiansen, A.H.J., 2001, Contour smoothing by an eclectic procedure: Photogrammetric engineering and Remote Sensing, v. 67, no. 4, p. 511-517. [splices arcs of quadratic parabolas to use both TIN \& its linearly interpolared contours]

Churchill, R.R., 1981, Aspect-related differences in badlands slope morphology: Annals of the Association of American Geographers, v. 71, no. 3, p. 374-388. [stats. \& anal. var. for 16 form variables fr segmented slope profiles]

Cipolletti, D.L., 1988, Morphometry of Central American composite cones: New Brunswick, NJ, Rutgers University, unpublished MA thesis, 56 p. [no info]

Clague, D.A., Moore, J.G., and Reynolds, J.R., 2000, Formation of submarine flat-topped volcanic cones in Hawai'i: Bulletin of Volcanology, v. 62, no. 3, p. 214-233. [height/diam., rim/base diam., depth/rim diam.; low \& broad]

Clague, D.A., Reynolds, J.R., and Davis, A.S., 2000, Near-ridge seamount chains in the northeastern Pacific Ocean: Journal of Geophysical Research, v. 105, no. B7, p. 16,541-16,561. [3 chains; edifice \& summit crater \& caldera morphometry; much var.]

Clark, C.D., and Meehan, R.T., 2001, Subglacial bedform geomorphology of the Irish ice sheet reveals major configuration changes during growth and decay: Journal of Quaternary Science, $v$. 15 , no. 5, p. 483-496. [lineaments \& variously processed DEM-views of ribbed (Rogen) moraine show ground texture better than satellite images]

Clark, W.A.V. and Gaile, G.L., 1973, The analysis and recognition of shapes: Geografiska Annaler, v. 55 B, p. 155-165. [shape characterization] 
Clarke, G.K.C., 1991, Length, width and slope influences on glacier surging: Journal of Glaciology, v. 37, no. 126, p. 236-246. [multivar. analysis of 1754 Yukon glac.: signif. diff. geom.; $L$ is dominant]

Clarke, G.K.C., Schmok, J.P., Ommanney, C.S.L., and Collins, S.G., 1986, Characteristics of surging glaciers: Journal of Geophysical Research, v. 91, no. B7, p. 7165-7180. [univariate analysis of 2356 Yukon glac.: longer glac. more likely to surge]

Clarke, K.C., 1997, Topography, geographical, in Trigg, G.L., ed., Testing Equipment-Mechanical to Topological Phase Effects, Encyclopedia of Applied Physics, v. 21: Weinheim, Wiley-VCH verlag, p. 525-531. [includes DEM's, relief depiction, morphometry, topology]

Clayton, Keith, and Shamoon, Nadhim, 1999, A new approach to the relief of Great Britain III. Derivation of the contribution of neotectonic movements and exceptional regional denudation to the present relief: Geomorphology, v. 27, nos. 3-4, p. 173-189. [isostatic uplift fr denudational unloading $\approx 50 \%$; other $=$ river slopes $(\approx f($ rock strength $)+$ misc.]

Cleveringa, Jelmer, and Oost, A.P., 1999, The fractal geometry of tidal-channel systems in the Dutch Wadden Sea: Geologie en Mijnbouw, v. 78, no. 1, p. 21-30. [fractal \& Horton analysis; channel systems similar]

Coe, J.A., and Godt, J.W., 2001, Debris flows triggered by the El Niño rainstorm of February 2-3, 1998, Walpert Ridge and vicinity, Alameda County, California: U.S. Geological Survey, Miscellaneous Investigations Series Map MF-2384, 22 p., 1:24,000 scale; http://geopubs.wr.usgs.gov/map-mf/mf2384/. [slope, curvature, upslope contrib. A on 10m DEM for 551 debris-flow source areas]

Cohen, J.E., and Small, Christopher, 1998, Hypsographic demography, the global distribution of human population with altitude: Proceedings of the National Academy of Sciences of the USA, v. 95, November, p. 14,009-14,014; http://www.Ideo.columbia.edu/ small/Pop/HypsoDemo/HypsoDemoMain.html. [Global systematics; As elev. < fr $800 \mathrm{~m}$ to $0 \mathrm{~m}$, no. people increase >exponentially while occupied land area increases linearly. Occupied area between $0 \& 100 \mathrm{~m}$ has disproportionate \% of world pop.]

Coleman, Alice, 1952, Some aspects of the development of the lower Stour, Kent: Proceedings of the Geologists' Association, v. 63, part 1, p. 63-86. [modified height-range plot of Sparks 1950; v. detailed (300 'flats')]

Collett, Bernard, Taud, Hind, and Parrot, J.-F., 1999, Anomalies altimétriques de la zone afro-arabe (in French): Eclogae Geol. Helvetica, v. 92, no. 3, p. 275-284. [modeled 'Afar Plume' topo fr. 1 km DEM (DCW) with spline fnc.]

Collin, Alexandre, 1846, Recherches expérimentales sur les glissements spontanés des terrains argileux, accompagnés de considérations sur quelques principes de la mécanique terrestre (in French; ... landslides in clay strata ... soil mechanics): Paris, Carilian-Goeury \& Damont, 2 vol., text 168 pages, atlas 21 plates. [early observation \& experiment; measured slopes \& before \& after profiles of slides in embankments; proposed a curved slip face]

Collins, Michael, 1999, The edge of the world-revisiting Earth curvature concerns in terrain modeling: Digital Data Digest (USACE/TEC), v. 5, no. 4, p. 5-7. [line-of-sight calcs. $>2000 \mathrm{~m}$ need correction for curvature]

Cook, A.C., and Robinson, M.S., 1999, Digital elevation models of the lunar surface, in Workshop on new views of the Moon II-understanding the Moon through the integration of diverse datasets: Houston TX, Lunar and Planetary Institute, LPI Contribution no. 980, p. 8-10. [fr Clementine UVVIS images; $1 / 5$ of Moon at $1 \mathrm{~km} / \mathrm{px}$; maria noisy, uplands best] 
Cook, A.C., Watters, T.R., Robinson, M.S., Spudis, P.D., and Bussey, D.J.B., 2000, Lunar polar topography derived from Clementine stereoimages: Journal of Geophysical Research, v. 105, no. E5, p. 12,023-12,033. [new $1 \mathrm{~km} /$ pixel DEM + laser altimetry = global topo map of Moon]

Coops, N.C., 2000, Comparison of topographic and physiographic properties measured on the ground with those derived from digital elevation models: Northwest Science, v. 74, no. 2, p. 116130. [old 90-m DMA DEM; also use to better relocate forest-survey plots]

Corominas, J., Baeza, C, and Salueña, I., 1992, The influence of geometrical slope characteristics and land use on the development of shallow landslides, in Bell, D.H., ed., Landslides, International Symposium 6th, 10-14 February, Christchurch NZ, Proceedings: Rotterdam, Balkema, v. 2, p. 919924. [field meas. of slide depth/length, slope, height, basin area, etc.; mult. regress. \& PCA]

Cory, M.J., and McGill, A., 1999, DTM derivation at Ordnance Survey Ireland: OEEPE Workshop on Automation in Digital Photogrammetric Production, 22-24 June, Ecole Nationale des Sciences Géographiques, Marne la Vallée (France); http://phot.epfl.ch/workshop/wks99/5_2.html. [new national 1:50K map series; contours fr DEMs by digital photogramm., largely automatically]

Court, Arnold, 1972, Heterodox hydrology: Geographical Analysis, v. 4, p. 194-196. [sharp attack on Wong 1963, esp. PCA; Wong reply 197-203]

Cowen, D.J., Jensen, J.R., Hendrix, Chad, Hodgson, M.E., and Schill, S.R, 2000, A GIS-assisted rail construction econometric model that incorporates LIDAR data: Photogrammetric engineering and Remote Sensing, v. 66, no. 11, p. 1323-1328. [3 m DEM from $0.3 \mathrm{~m}$ data; considerable treecanopy cover tolerated]

Cox, E.P., 1927, A method of assigning numerical and percentage values to the degree of roundness: Journal of Paleontology, v. 1, no. 3, p. 179-183. [early work: $R=$ $4 \pi r($ area $\left.) /(\text { perimeter })^{2}\right]$

Cox, R.T., 1994, Analysis of drainage-basin symmetry as a rapid technique to identify areas of possible Quaternary tilt-block tectonics_an example from the Mississippi Embayment: Geological Society of America Bulletin, v. 106, no. 5, p. 571-581. [polar plots of asymmetry vectors (calc. fr transverse topo profiles) for 271 basin segments \& streams]

Cracraft, Joel, 1980, Review of The Measurement of Biological Shape and Shape Change, by F.L. Bookstein, F.L., 1978: Systematic Zoology, v. 29, no. 1, p. 102-103. [quant. measurement of shape as the core os systematics; parallels in specific geomorphometry]

Craddock, R.A., and Howard, Alan D., 2000, Simulated degradation of lunar impact craters and a new method for age dating farside mare deposits: Journal of Geophysical Research, v. 105/E8, p. 20,387-20,401. [validates Pike 1974 \& 1977 lunar-crater d/D \& h/D data]

Crave, Alain, and Davy, Philippe, 1997, Dynamique et géométrie des réseaux hydrographiques (in French), in Davy, Philippe, Guillocheau, François, and Hamelin, Bruno, eds., Géomorphologie-Processus et Modélisation: Rennes, Geosciences-Rennes, p. 39-43. [brief examples of analysis of stream networks]

Crave, Alain, and Davy, Philippe, 2001, A stochastic "precipiton" model for simulating erosion/sedimentation dynamics: Computers and Geosciences, v. 27, no. 7, p. 815-827. [based on cellular automata]

Crave, Alain, Lague, D., Davy, Philippe, Kermarrec, J., Sokoutis, D., Bodet, L., and Compagnon, R., 2000, Analogue modelling of relief dynamics: Physics and Chemistry of the Earth (A), v. 25, no. 67, p. 549-553. [rain-erosion; parameters fr DEM of scale model @ $\pm 100 \mu \mathrm{Z} \& \pm 500 \mu \mathrm{XY}$ ] 
Crawford, J.W., Baveye, Philippe, Grindrod, Peter, and Rappoldt, Cornelius, 1999, Application of fractals to soil properties, landscape patterns, and solute transport in porous media, in Corwin, D.L., Loague, Keith, and Ellesworth, T.R., eds., Assessment of non-point source pollution in the vadose zone: Washington, D.C., American Geophysical Union, Geophysical Monograph 108, p. 151-164. [good tips on using fractal D, p. 152-156]

Cronin, Terrence, 1999, A boundary concavity code to support dominant point detection: Pattern Recognition Letters, v. 20, no. 6, p. 617-634. [identifies spurs \& draws (small ridges \& valleys) from shape of indiv. contours]

Cronin, Terrence, 2000, Classifying hills and valleys in digitized terrain: Photogrammetric Engineering and Remote Sensing, v. 66, no. 9, p. 1129-1137. [fr. containment relations of nested contours, not DEM's; can use open contours at edge of map; good review of prior work]

Cross, Martin, 1998, Landslide susceptibility mapping using the Matrix Assessment Approach-a Derbyshire case study, in Maund, J.G., and Eddleston, Malcolm, eds., Geohazards in Engineering Geology: London, The Geological Society, Engineering Geology Special Publication no. 15, p. 247-261. ['MAP'; deep-seated slides; bedrock geol. \& slope best; relief, aspect \& soils good]

Crosta, G.B., 2000, Detailed report of contractor (DAMOCLES-EVG1-1999-00027P) for first progress meeting: Dept. di Science Geologiche e Geotecnologie, Univ. Milano-Bicocca (UNIBICO), October (for period April-Sept. 2000), 10 p.; http://damocles.irpi.pg.cnr.it/docs/october-2000/mi-october2000.pdf. [list of 27 morphometric parameters used to describe alluvial fans \& catchments in Lombardy]

Crown, D.A., and Baloga, S.M., 1999, Pahoehoe toe dimensions, morphology, and branching relationships at Mauna Ulu, Kilauea Volcano, Hawai'i: Bulletin of Volcanology, v. 61, no. 5, p. 288305. [445 toes; L, W, thickness, orientation; slope affects aspect ratio, etc.]

Crozier, M.J., Eyles, R.J., Marx, S.L., McConchie, J.A., and Owen, R.C., 1980, Distribution of landslips in the Wairarapa hill country: New Zealand Journal of Geology and Geophysics, v. 23, nos. $5 \& 6$, p. 575-586. [slope gradient, aspect, \& profile location (high, mid, low) of 2206 landslides \& parent hillsides]

Cruden, D.M., and Hu, X.-Q., 1999, The shapes of some mountain peaks in the Canadian Rockies: Earth Surface Processes and Landforms, v. 24, no. 13, p. 1229-1241. [slope (cataclinal, anaclinal, dihedral) varies by rock structure; 5 shape types]

Culling, W.E.H., 1960, Analytical theory of erosion: Journal of Geology, v. 68, no. 3, p. 336-344. [by hypothesizing that horizontal flux of eroded material $\approx$ slope gradient, introduced use of geomorphic 'transport laws' in the conservation of mass to explore controls on landscape form \& dynamics; 1 st to apply the classical diffusion equation to geomorphology]

Cunit, C., 1855, Études sur les cours d'eau à fond mobile: Grenoble, publisher \& paging unknown. [his courbe de régularisation $=$ concept of a limiting slope for fluvial transport]

Currado, Claudia, and Fredi, Paola, 2000, Morphometric parameters of drainage basins and morphotectonic setting of eastern Abruzzo: Memorie della Società Geolica Italiana, v. 55, p. 411419. [relief map; stream orientations; asymmetry \& transverse topo. factors]

Currey, D.R., 1964, A preliminary study of valley asymmetry in the Ogototuk Creek area, northwestern Alaska: Arctic, v. 17, no. 2, p. 84-98. [232 map \& airphoto slope \& azimuth obs. for stream orders 1-4 quantify $\mathrm{N}$ (steeper) / $\mathrm{S}$ asymmetry]

Curry, A.M., 1999, Paraglacial modification of slope form: Earth Surface Processes and Landforms, v. 24 , no. 13 , p. 1213-1228. [surveyed gully L, W, depth, vol; nongullied terrain slope \& concavity] 
Cybulz, Ignatz, 1862, Handbuch der Terrain-Formenlehre, mit einem Anhange über elementarUnterricht in Terrain-Zeichen nach plastischem unterrichts-Material (in German): Vienna, W.

Braumüller, 200 p. [maps \& profiles emph. geometry of forms; earliest (?) illustr. (albeit not 3-D) of the 9 slope elements (predates all other refs.); uses Lehmann's (1799) quant. hachure method]

Da Fontoura Costa, Luciano, and Cesar, R.M. Jr., 2000, Shape Analysis and Classification-Theory and Practice: Boca Raton, FL, CRC Press, 659 p. [comprehensive 2-D computer-based shape recognition \& analysis, incl. measures for statistical classification; no Earth-sciences examples!]

Dade, W.B., 2000, Grain size, sediment transport and alluvial channel pattern: Geomorphology, v. 35 , nos. 1-2, p. 119-126. [channel sinuosity related to slope, other params.]

Dade, W.B., 2001, Multiple scales in river basin morphology: American Journal of Science, v. 301, no. 1, p. 60-73. [quant. relations among area, relief, \& steepness suggest influence of multiple spatial scales]

D'Alessandro, Leandro, Del Monte, Maurizio, Fredi, Paola, Lupia Palmieri, E., and Peppoloni, Silvia, 1999, Hypsometric analysis in the study of Italian drainage basin morphoevolution: Transactions, Japanese Geomorphological Union, v. 20, no. 3, p. 187-202. [mult. regression of H on 5 var.; Adriatic \& Tyrrhenian basins differ]

Danielson, J.J., 1998, Delineation of drainage basins from $1 \mathrm{~km}$ African digital elevation model, in Human Interactions with the Environment-Perspectives from Space, Pecora 13, Sioux Falls, SD, August 20-22, 1996, Proceedings: Bethesda, MD, American Society of Photogrammetry and Remote Sensing, CD-ROM; also <http://www.1.gsi-mc.go.jp/gtopo30/papers/danielson.html>. [DEM-to-watershed transform applied to the GTOPO30 DEM]

DARPA, 2002, Geospatial Terrain Analysis and Representation (Geo*): Defense Advanced Research Projects Agency, Defense Sciences Office: http://www.darpa.mil/dso/future/geo/. forum on math. representation \& analysis of geospatial data for military applics.]

[WWW info. \&

Dausse, M.F.B., 1857, Note sur un principe important et nouveau d'hydrologie: Compte Rendus de l'Academie sed Sciences, Paris, v. 44, p. 756-766. [his pente de de'équilibre = concept of a limiting slope for fluvial transport]

Dauteuil, Oliver, Blais, Sylvain, Miau, Delphine, Guille, Gérard, and Maury, R.C., 1988, Apports et limites de l'imagerie SPOT et du modèle numérique de terrain pour l'étude du volcanisme intraocéanique-exemple des îsles de Raiatea et de Tahaa (archipel de la Société, Polynésie française): Géologie de la France, no. 3, 1998, p. 37-50. [20-m DEM @ \pm 25 m vert. fr 1958 IGN contours; alt. freq., topo profiles]

Davis, P.T., 1999, Cirque morphometry, pp. 34-39, in Cirques of the Presidential range, New Hampshire, and surrounding alpine areas in the northeastern United States: Géographie physique et Quaternaire, v. 53, no. 1, p. 25-45;

http://216.239.33.100/search?q=cache:FDC2dANUwmUC:www.erudit.org/erudit/gpq/v53n01/davis/ davis.htm+W.+F.+Thompson+mountains+morphometry\&hl=en\&ie=UTF-8. [12 params. on 44 cirques fr $1 / 20 \mathrm{~K}-1 / 25 \mathrm{~K}$ maps, but little stat. analysis; good biblio on prior morphometry]

Davoli, Lina, Del Monte, Maurizio, De Rita, Donatella, and Fredi, Paola, 1999, Geomorphology and tectonics in the Roccamonfina Volcano (Campania - central Italy): Zeitschrift für Geomorphologie, Supplementband 114, p. 11-28. [relief amplitude (i.e. 'relief energy', or local relief) \& drainage density on $1 \mathrm{~km}$ squares] 
Davy, Philippe, and Crave, Alain, 2000, Upscaling local-scale transport processes in large-scale relief dynamics: Physics and Chemistry of the Earth (A), v. 25, no. 6-7, p. 533-541. [broad-scale surface model based on DEM-driven erosion dynamics]

De Beauclair Seixas, Roberto, de Figueiredo, L.H., da Silva, C.A., and Carvalho, P.C.P., 2000, Uma metodologia para geração de modelos de elevação a partir de curvas de nível (in Portuguese; a method to generate elevation models from contours): Anais do Geolnfo 2000, p. 82-87. [contour-to-DEM interpolation; after Gousie 1998]

De Berg, M., Bose, P., Dobrint, K., van Kreveld, M., Overmars, M., de Groot, M., Roos, T., Snoeyink, J., and Yu, S., 1996, The complexity of rivers in triangulated terrains, in Canadian Conference on Computational Geometry, 8th, Proceedings: p. 325-330. [worst-case edge complexity can be quadratic (i.e., bad) in TIN-to-watershed computations]

De Blasio, F.V., 2002, Note on simulating the size distribution of glacial cirques: Earth Surface Processes and Landforms, v. 27, no. 1, p. 109-114. [narrow size-distr. reproduced fr kinematic stochastic model]

De Chant, L.J., Pease, P.P., and Tchakerian, V.P., 1999, Modelling alluvial fan morphology: Earth Surface Processes and Landforms, v. 24, no. 7, p. 641-652. [diffusive sed. transp. \& unsteady radial flow; sed \& flow more importand than climate \& lithol.?]

De Floriani, Leila, and Puppo, Enrico, 1992, A hierarchical triangle-based model for terrain description, in Frank, A.K., Campari, I., \& Formentini, U., eds., Theories and Methods of SpatioTemporal Reasoning in Geographic Space: Lecture Notes in Computer Science, v. 63, no. 9, Berlin \& Heidelberg, Springer Verlag. p. 236-251. [define DTM as 1 "a partition of the groundplan, \& 2 a family of partially continuous functions, one specified for each part of the partition, \& all fncs together form a continuous surface representing the terrain"]

De Floriani, Leila, and Magillo, Paola, 1999, Intervisibility on terrains, ch. 38, in Longley, P.A., Goodchild, M.F., Maguire, D.J., and Rhind, D.W., eds., Geographical Information Systems, v. 1, Principles and Technical Issues, 2nd ed.: New York, Wiley, p. 543-556. [reviews geometric modeling of viewsheds etc.]

De Floriani, Leila, Magillo, Paola, and Puppo, Enrico, 2000, VARIANT—a system for terrain modeling at variable resolution: Geoinformatica, v. 4, no. 3, p. 287-315. [storage, manipulation, analysis, \& visualizing costs $>$ w/ DEM resolution \& accuracy]

De Scally, F.A., Slaymaker, Olav, and Owens, I.F., 2001, Morphometric controls and basin response in the Cascade Mountains: Geografiska Annaler, v. 83 A, no. 3, p. 117-130. [moment stats on 9 params. for 36 debris torr., 79 avalanche, 45 mixed, \& 14 stream basins]

De Smet, Roger, 1951, Principles élémentaires de morphométrie (in French): Rev. Cercle des Sciences (Brussels), v. 1, no. 4, p. 13-16. [no info; see his other 1951 paper]

De Villiers, A.B., 1986, A multivariate evaluation of a group of drainage basin variables - a South African case study, in Gardiner, V., ed., International Geomorphology 1986, Part II: New York, John Wiley \& Sons, p. 21-32. [correl. \& Fact. Anal. of 59 var. (167 basins): size (max), relief, soil type, texture, eros. index, circularity]

Debenham, Frank, 1937, Exercises in Cartography: London, publ. unknown, p. 60. [measured contour length by opisometer to calc. clinographic curves]

DeBruin, S., Wielemaker, W.G., and Molenaar, M., 1999, Formalisation of soil-landscape knowledge through interactive hierarchical disaggregation: Geoderma, v. 91, nos. 1-2, p. 151-172. [spatial topologic concepts: containment, adjacency, overlap] 
Deffontaines, Benoît, Chotin, Pierre, Aït Brahim, Lahsen, and Rozanov, Michel, 1992, Investigation of active faults in Morocco using morphometric methods and drainage pattern analysis:

Geologische Rundschau, v. 81, no. 1, p. 199-210. [maps of summit levels, morphostruct. blocks, comp. w/ drainage net]

Deffontaines, Benoît, 1997, Quelques reflexions en morphometrie et morphostructurale (in French), in Davy, Philippe, Guillocheau, François, and Hamelin, Bruno, eds., Géomorphologie-Processus et Modélisation: Rennes, Geosciences-Rennes, p. 99-106. [brief examples of DEM-based analysis of streams \& relief; biblio]

Defourny, P., Hecquet, G., and Philippart, T., 1999, Digital terrain modelling-accuracy assessment and hydrological simulation sensitivity, Ch. 7 in Lowell, Kim, and Jaton, Annick, eds., Spatial Accuracy Assessment-Land Information Uncertainty in Natural Resources: Chelsea, MI, Ann Arbor Press, p. 61-70. [pt elevs > contours, kriged elevs = best DEM, etc.; hydro models v. sensitive to quality]

DeGraff, J.V., 1978, Regional landslide evaluation-two Utah examples: Environmental Geology, v. 2 , no. 4, p. 203-214. [susceptibility based on bedrock ( $\%$ area), slope ( $\%$ area), \& aspect]

DeGraff, J.V., and Romesburg, H.C.,1980, Regional landslide-susceptibility assessment for wildland management-a matrix approach, in Coates, D.R., and Vitek, J.D., eds., Thresholds in Geomorphology: London, George Allen and Unwin, p. 401-414. [large-area mapping by quant. combination of rock type \& ground slope \& aspect]

Dehn, Martin, Gärtner, Holger, and Dikau, Richard, 1999, Principles of semantic modeling of landform structures, in International Conference on GeoComputation, 4th, Fredericksburg VA, Mary Washington College, 25-28 July, GeoComputation 99: http://www.geovista.psu.edu/geocomp/geocomp99/Gc99/067/gc_067.htm. [semantic representation must precede DEMs, tools, implementation]

Del Monte, Maurizio, Fredi, Paola, Palmiere, E.L., and Salvini, Francesco, 1997, Fractal characterisation of drainage network geometry: Geogr. Fis. Dinam. Quat., Suppl. III, v. 1, p. 144145. [no info]

Del Monte, Maurizio, Fredi, Paola, Palmiere, E.L., and Salvini, Francesco, 1999, Fractal analysis to define the drainage network geometry: Bolletino della Società Geologica Italiana, v. 118, no. 1, p. 167-177. [D rises with > structural control: dendritic-pinnate-parallel-rectangular]

Delazari, L.S., Vieira, A.J.B., and Dalmolin, Quintino, 1998, Extração automática de canais de drenagem utilizando modelos digitais de altitude (in Portugese; ... network drainage from DEMs): Boletim Paranaense de Geociências, no. 46, p. 91-96. [DEM-to-watershed mapping using SKEL pkg. of Meisels et al. 1995]

Delcaillau, B., Ozouf, J.C., Masiee, D., Laville, E., and Coutard, J.P., 1998, Evolution geomorphologique d'un bassin versant cotier; l'exemple de la Touques (Basse-Normandie) (... coastal drainage basin... in French): Comptes Rendus de l'Academie des Sciences, Serie II. Sciences de la Terre et des Planetes, v. 326, no. 9, p. 609-615. [longitudinal profiles \& hypsometric integrals related to basin immaturity]

Delclaux, F., and Depraetère, Christian, 2001, Methodological approach for hydrological landscape definition-application of texture measures on West-African watersheds: Actes du 8ème Congrès Européen de Stéréologie et d'Analyse d'Images, Bordeaux, France, (supl 1), p. 590-595. [texture metrics; see other 2001 citation]

Delclaux, F., and Depraetère, Christian, 2001, Quantitative approach for the determination of hydrological landscapes, in Falconer, R.A., and Blain, W.R., eds., River Basin Management: 
Southampton UK, Boston MA, WITT Press, p. 283-292. [PCA of 9 texture parameters, 1st PC (overall homogeneity) 58\%, 2nd (patch clustering) 26\%, 3rd (local heterogeneity) $8 \%$ ]

DeLoach, S.R., and Leonard, Jeff, 2000, Making photogrammetric history: Professional Surveyor, v, 20 , no. 4 , p. $6,8,10 . \quad$ [rather boosterish review of LIDAR as source for topo data]

Demanet, Donat, Pirard, Eric, Renardy, François, and Jongmans, Denis, 2001, Application and processing of geophysical images for mapping faults: Computers and Geosciences, v. 27, no. 9, p. 1031-1037. [math. morphology; gradient images= topo relief; define crest lines]

Demangeot, Jean, 1939, Le relief de la Haute Ubaye (in French): Annales de Géographie, v. 48, p. 343-358. [measured mean elevation, etc.]

Demangeot, Jean, 1943, Notes sur la Haute Vallée de l'Ubaye (in French): Revue de Géographie Alpine, v. 31 , no. 4, p. 535-574. [p. 556-563 on mean height \& other indices for var. litho-struct. zones]

Demirmen, Ferruh, 1975, Profile analysis by analytical techniques, a new approach: Geographical Analysis, v. 7, no. July, p. 245-266. [defines profile types \& proposes params = height, relief, length, slope, curv.]

Dengler, Lori, and Montgomery, D.R., 1989, Estimating the thickness of colluvial fill in unchanneled valleys from surface topography: Bulletin of the Association of Engineering Geologists, v. 26, no. 3, p. 333-342. [2 trig. rels. betw. contour spacing \& slope; planar \& convex slide slopes]

Denizman, C., and Randazzo, A.F., 2000, Post-Miocene subtropical karst evolution, lower Suwannee River basin, Florida: Geological Society of America Bulletin, v. 112, no. 12, p. 1804-1813. [sinkhole circularity/elev.; terrace growth ratio/elev.; pitting index/distance]

Denness, B., and Grainger, P., 1976, The preparation of slope maps by the moving interval method: Area, v. 8, p. 213-218. [manual method, not obsoleted by computer where detail needed]

Denny, C.S., 1965, Alluvial fans in the Death Valley region, California and Nevada: U.S. Geological Survey Professional Paper 466, 62 p. [early fan morphometry; isometric log-log plots interpr. as steady-state form-process relations]

Denny, C.S., 1967, Fans and pediments: American Journal of Science, v. 265, no. 2, p 81-105. [early fan morphometry; exponential trend (no eqn.) interpr. as steady-state form-process relations]

Densmore, A.L., and Hovius, Niels, 2000, Topographic fingerprints of bedrock landslides: Geology, v. 28 , no. 4 , p. 371-374. [prob. of $>40^{\circ}$ slope per horiz. distance from channel normalized by hillslope length, fr 30-m \& 50-m DEMs]

Desmet, P.J.J., and Govers, G., 1996, A GIS procedure for automatically calculating the USLE LS factor on topographically complex landscape units: Journal of Soil and Water Conservation, v. 51, no. 5, p. 427-433. [automated unit-contributing-area concept extends Foster \& Wischmeier 1974 approach]

Deutsch, C.V., and Journel, A.G., 1998, GSLIB-Geostatistical Software Library and User's Guide, second edition: New York, Oxford University Press, 369 p. + CD-ROM. [a 'how to' book; FORTRAN 77 code furnished; see Myers review]

Devarajan, Venkat, Fuentes, R.W., and McArthur, D.E., 1996, An approach to multiple levels of detail generation from digital terrain elevation data using wavelet transforms: International Training Equipment Conference, 7th, Singapore, September 24-26, Proceedings: p. 255-262. [see McArthur et al., 2000; no other info] 
Devdariani, A.S., 1967, The profile of equilibrium and a regular regime (fr Voprosy geografii, Quantitative Methods in Geomorphology, no. 63, 1963, p. 33-48): Soviet Geography, Review and Translation, v. 8, no. 2, p. 168-183. [fit theor. eqn. to longitudinal profile, but had to omit realworld irregularities]

Devdariani, A.S., 1967, A plane mathematical model of the growth and erosion of an uplift (fr Izvestiya Akademii Nauk SSSR, seriya geograficheskaya, 1966, no. 3, p. 7-16): Soviet Geography, Review and Translation, v. 8, no. 2, p. 183-198. [early Russian quant. 2-D model of Davisian landscape evolution]

Develi, K., Babadagli, T., and Comlekci, C., 2001, A new computer-controlled surface-scanning device for measurement of fracture surface roughness: Computers and Geosciences, v. 27, no. 3, p. 265-277. [54 x 54mm area, $1.0 \mathrm{~mm} \mathrm{XY} \mathrm{\&} 0.1 \mathrm{~mm} \mathrm{Z} \mathrm{resolution]}$

Di Stefano, C., Ferro, V., Porto, P., and Tusa, G., 2000, Slope curvature influence on soil erosion and deposition processes: Water Resources Research, v. 36, no. 2, p. 607-617. [modeled hydraulic-path correction for topo factors of RUSLE; DEM test]

Diener, Carl, 1890, Generalmajor A. v. Tillo's hypsometrische Karte des europäischen Rußland (in German): Petermanns Geographische Mitteilungen, v. 36, no. 6, p. 156-158. [detailed discussion of Tillo's 1889 map \& its construction; small map shows area over $170 \mathrm{~m}$ ]

Dierking, Wolfgang, 1999, Quantitative roughness characterization of geological surfaces and implications for radar signature analysis: IEEE Transactions on Geoscience and Remote Sensing, v. 37, no. 5, p. 2397-2412. [stationary-radom-process \& power-law models for SAR images; several signatures]

Dietrich, W.E., and Montgomery, D.R., 1998a, Hillslopes, channels, and landscape scale, in Sposito, Garrison, ed., Scale Dependence and Scale Invariance in Hydrology: Cambridge, UK, Cambridge University Press, p. 0-60. [processes \& thus terrain are scale-invariant; drainage density, slope \& relief important; DEM's essential]

Dietrich, W.E., and Montgomery, D.R., 1998b, SHALSTAB a digital terrain model for mapping shallow landslide potential: http://socrates.berkeley.edu/ geomorph/shalstab/ (to be published as a technical report by NCASI). [conceptual framework, theory, application, testing, prescriptive use; can download zip file w/ code and documentation for use with ArcView GIS]

Dietrich, W.E., Bellugi, Dino, Heimsath, A.M., Roering, J.J., Sklar, L.S., and Stock, J.D., 2002, Geomorphic transport laws for predicting landscape form and dynamics, in Iverson, R.M., and Wilcock, P., eds., Geomorphic Modeling: American Geophysical Union Monograph, in press. [wide-ranging study demonstrates via DEMs how GTLs might model real landscapes]

Dietrich, W.E., Wilson, C.J., and Reneau, S.L., 1986, Hollows, colluvium, and landslides in soilmantled landscapes, in Abrahams, A.D., ed., Hillslope Processes, proceedings of the 16th annual Binghamton symposium in geomorphology: Boston, MA, Allen and Unwin, p. 361-388. [area \& gradient inversely log-log related to hollow area \& length; leads to basis for formational model]

Dikau, Richard, 1988, Entwurf einer geomorphologisch-analytischen Systematik von Reliefeinheiten (Design of geomorphologic-analytic systematics of relief units, in German): Heidelberger Geographische Bausteine (Heidelberg geogr Contrib.), no. 5, 45 p. [mapping strategy based on work of $\mathrm{H}$. Kugler]

Dikau, Richard, 1994, Computergestützte Geomorphographie und ihre Anwendung in der Regionalisierung des Reliefs (in German): Petermanns Geographische Mitteilungen, v. 138, no. 2, p. 99-114. [quant. landform regions in New Mexico (Hammond method) \& SW Germany (flow routing)] 
Dikau, Richard, 1996, Geomorphologische Reliefklassifikation und -analyse (in German with english abstract): Heidelberger Geographische Arbeiten, v. 104, p. 15-23. [proposes nested landform hierarchies as multi-scale approach to geomorphometry]

Dikau, Richard, and Friedrich, K., 1999, Digitale Reliefmodellierung (in German), in Zepp, H., and Müller, M.J., eds., Landschaftsökologische Erfassungsstandards-Ein Methodenhandbuch: Flensburg, Forschungen zur Deutsche Landeskunde, v. 244, p. 50-68. [another overview of Dikau's systematic approach to terrain representation]

Dikau, Richard, and Saurer, Helmut, eds., 1999, GIS for Earth Surface Systems Analysis and Modelling of the Natural Environment: Stuttgart, Borntraeger, 197 p. [many DEM-based geomorph. applications]

Dikau, Richard, and Schmidt, Jochen, 1999, Georeliefklassifikation (in German), in Schneider-Sliwa, Rita, Schaub, Daniel, and Gerold, Gerhard, eds., Angewandte Landschaftsökologie-Grundlagen und Methoden: Berlin, Springer-Verlag, p. 217-244. [restated overview of Dikau's systematic approach to terrain representation]

Dikau, Richard, Hennrich, Kirsten, and Schmidt, Jochen, 1999, Untersuchungen zur computergestützten Regionlisierung von geomorphometrischen Reliefmerkmalen und ihre Parametrisierung in Niederschlags-Abfluß-Modellen in Einzugsgebieten unterschiedlicher Größenordnung (in German with English abstract; ... computer-assisted regionalization of geomorph. relief features \& their parameterizing in rainfall-runoff models in catchment areas of different orders ..., in Kleeberg, H.-B., Mauser, Wolfram, Peschke, Gerd, and Streit, Ulrich, eds., Hydrologie und Regionalisierung: Deutsche Forschungsgemeinschaft, Forschungsbericht, WileyVCH, p. 175-189. [hydro models TOPMODEL \& SAKE; 35 dimension, form, \& relief params. fr GRASS \& ARC/INFO; spatial taxonomy]

Dikau, Richard, Hennrich, Kirsten, Schmidt, Jochen, Flechtner, Iris, Jung, Petra, and Schroeder, Martin, 1997, Untersuchungen zur computergestützten Regionlisierung von geomorphometrischen Reliefmerkmalen und ihre Parametrisierung in Niederschlags-Abfluß-Modellen unterschiedlicher Größenordnung (in German): Abschlußbericht zum Forschungsantrag im Rahmen des DFGSchwerpunktprogramms 'Regionalisierung in der Hydrologie', Universität Bonn, Geographisches Institut, paging unknown. [see Dikau-Hennrich-Schmidt 1999. also same citation, but Dikau, Schmidt, Schumacher (Thomas), Hennrich, \& Schroeder, 1995, Univ. Heidelberg - no info]

Dirichlet, G.L., 1850, Über die reduction der positiven quadratischen formen mit drei unbestimmten ganzen zalen: J. Reine u. Angew. Math., v. 40, p. 209-227. [landmark in spatial analysis; Dirichlet studied geometric tessellation before Voronoi; thus, diagram is sometimes called Dirichlet tessellation]

Discoe, Ben, 2001, The Virtual Terrain Project - "tools for easily constructing any part of the real world in interactive 3D digital form; a set of open-source libraries \& applications which enable the rapid construction of interactive 3D scenes from geospatial data for anywhere on the planet": $<$ http://www.vterrain.org/>. [as of 02/20002, a comprehensive site with up-to-date info on digital terrain rendering]

Djokic, Dean, and Maidment, David, eds., 2000, Hydrologic and Hydraulic Modeling Support with Geographic Information Systems: Redlands CA, ESRI Press, 232 p. [5 DEM-related papers fr 1999 ESRI users' conference]

Djokic, Dean, and Ye, Zichuan, 2000, DEM preprocessing for efficient watershed delineation, paper 4 in Djokic, Dean, and Maidment, David, eds., Hydrologic and Hydraulic Modeling Support with Geographic Information Systems: Redlands CA, ESRI Press, p. 65-84; also http://www.esri.com/library/userconf/proc99/proceed/papers/pap676/p676.htm. [Fast watershed delineation (FWD) method speeds up pre-proc. the DEM-to-watershed transformation] 
Djokic, Dean, Ye, Zichuan, and Miller, A., 1997, Efficient watershed delineation using ArcView and Spatial Analyst, in 1997 ESRI International User Conference, San Diego, CA, July 8-11, Proceedings: Redlands, CA, Environmental Systems Research Institute, Inc., CD-ROM (can't locate this reference). [ESRI incorporates the DEM-to-watershed transformation into their software]

Dobija, A., 1979, Correlational analysis of morphometric parameters of drainage basins (in Polish): Zesz. Nauk. Univ. Jagiellon., p. 540ff. [no info]

Dodds, P.S., and Rothman, D.H., 1999, Unified view of scaling laws for river networks: Physical Reviews E, v. 59, no. 5, p. 4865-4877. [more direct descr. of XY river structure than Horton laws, based on Tokunaga scaling ( $\mathrm{T} \& \mathrm{H}$ laws are equivalent if their drainage densities are similar)]

Dodds, P.S., and Rothman, D.H., 2000, Scaling, universality, and geomorphology, in Jeanloz, Raymond, Albee, A.L., and Burke, K.C., eds., Annual Review of Earth and Planetary Sciences, v. 28: Palo Alto CA, Annual Reviews, p. 571-610. [pedagogic rev.; advoc. simple models to expl. steady-state scaling laws for river networks XY \& statistical structure of topo. Z; lists 15 scaling laws (Hack's law central; they find exponent $=0.5$, not 0.6 , for v. large basins); good biblio]

Dodds, P.S., and Rothman D.H., 2001a, Geometry of river networks-scaling, fluctuations, and deviations: Physical Review E, v. 63, 016115, 13 p. [generalize Hack's Law to a joint PDF \& use to reveal that fluctuations $\mathrm{fr}$ it $>\mathrm{w} /$ basin size]

Dodds, P.S., and Rothman D.H., 2001b, Geometry of river networks II—distributions of component size and number: Physical Review E, v. 63, 016116, 15 p. [Horton's laws extended to include fluctuations in scaling; distr. of stream segment lenghts are exponential]

Dodds, P.S., and Rothman D.H., 2001c, Geometry of River Networks III—characterization of component connectivity: Physical Review E, v. 63, 016117, 10 p. [self-similar scaling of drainage density implies Tokunaga's law, the scaling of side branch abundance along a stream, \& a scaling law for stream lengths]

Dombrowski, Pierre, 1979, 150 Years After Gauss' "Disquisitiones Generales Circa Superficies Curvas" (2nd ed., 1981): Paris, Société Mathématique de France, ser. Astérisque, No. 62, 153 p. [translation of this seminal 1827 work on the geometry of curves surfaces is from Hiltebeitel \& Morehead 1902 (reprinted 1965)]

Domogalla, P., Mair, G., and Schmidt, R.-G., 1974, Ein Beitrag zur quantitativen Erfassung des Reliefs für die Darstellung in geomorphologischen Karten (A contribution to the quantitative use of relief-representation in geomorphologic maps): Kartographische Nachrichten, v. 24, no. 3, p. 99104. [no info]

Dorey, M.I., Sparkes, A.J., Kidner, D.B., Jones, C.B., and Ware, J.M., 1999, Terrain modelling enhancement for intervisibility analysis, in Gittings, B.M., ed., Innovations in GIS 6: London, Taylor \& Francis, p. 169-184. [accuracy nearly doubles by adding topographic features to DEM]

Dornbusch, W.K., Jr., 1963, Quantitative terrain mapping in the humid tropics, Puerto Rico and the Canal Zone, in Military Evaluation of Geographic Areas reports on activities to April 1963: Vicksburg, Mississippi, U.S. Army Corps of Engineers Waterways Experiment Station, Miscellaneous Paper no. 3-610, p. 73-81. [applies the 4-param. USWES model: plan-profile, slope, spacing, relief]

Doucette, Peter, and Beard, Kate, 2000, Exploring the capability of some GIS surface interpolators for DEM gap fill: Photogrammetric Engineering and Remote Sensing, v. 66, no. 7, p. 881-888. [splining rather better than kriging, inv. dist. weighting, \& sfce trend analysis]

Dougherty, D.A., and Moellering, Harold, 1996, Using the 2-dimensional Fourier transform for numerical terrain analysis, in ASPRS/ACSM Annual Convention \& Exposition, 22-25 April, 
Bethesda, MD, ACSM Technical Papers: v. 3, Surveying \& Cartography, p. 268-277. ['signatures for numerical terrain types'; no other info]

Douglas, D.H., 1983, The XYNIMAP family of programs for geographic information processing and thematic map production, in Wellar, B.S., ed., Auto-Carto Six, International Symposium on Automated Cartography 6th, Ottawa Canada, Proceedings: v. II, p. 2-14. [interpolates contours; run 8 rays fr each unknown point until hit known pts, then postprocess to smooth surface; basis of CONSURF contour-to-grid algorithm]

Douglas, D.H., 2000, CONSURF—the Douglas contour to grid methodology: http://www.hig.se/ dds/research/consurf/consur1.htm. [intersection of slope line thru a point \& relevant contour lines intractable (both lines are curved); sol'n (based on 1983 XYNIMAP paper) uses slope lines; illustr. by animations]

Dowman, I.J., 2000, Review of Generation of Digital Elevation Models Through Spaceborne SAR Interferometry, by D. Small: Photogrammetric Record, v. 16, no. 95, p. 870-871. [hybrid text/Ph.D. thesis; mixed praise \& limits; good on DEM analysis]

Doytsher, Yerahmiel, and Hall, J.K., 2001, Simplified algorithms for isometric and perspective projections with hidden line removal: Computers and Geosciences, v. 27, no. 1, p. 77-83. [includes brief review of older hidden-line software]

Drzewiecki, Wojciech, Mularz, Stanislaw, and Pirowski, Tomasz, 1999, Generating slope and aspect maps using different GIS packages (in Polish with English abstract): Geodezja, v. 5, no. 1, p. 101122. [IDRISI, SURFER, ARC/INFO GRID, ERDAS, MGE GRID \& TERRAIN ANALYST, PC RASTER; results not in English]

Dubois, R.N., 2001, Using a quadratic model to theoretically describe the nature of equilibrium shorerise profiles: Journal of Coastal Research, v. 17, no. 3, p. 599-610. $\quad$ [relief $=a x^{2}+b x+c,(x=$ distance); $r^{2}=0.95-0.99$ for 74 profiles]

DuBuat, P.L.G., 1779, Principes d'Hydraulique, vérifiés par un grand nombre d'Expériences faites par ordre du Gouvernement (2nd ed. 1786, 3-vol. 3rd ed. 1816): Paris, De l'imprimerie de Monsieur, v. 1, 453 p., v. 2, 402 p. [landmark; many quant. experiments suggest dynamic adjustment of form to process re. hydraulic geometry; influenced De La Noë 1888?]

Dubuc, B., and Dubuc, S., 1996, Error bounds on the estimation of fractal dimension: SIAM Journal of Numerical Analysis, v. 33, no. 2, p. 602-626. [re surface roughness; diff. methods, scale ranges \& resolutions yield $v$. diff. estimates]

Duchaineau, Mark, Wolinsky, Murray, Sigeti, D.E., Miller, M.C., Aldrich, Charles, and MineevWeinstein, M.B., 1997, ROAMing terrain-Real-time Optimally Adapting Meshes: ACM Symposium Volume Visualization '97, IEEE, 19-24 October, Phoenix AZ, Proceedings: p. 81-88; $<$ http://www.Ilnl.gov/graphics/ROAM/>. [important paper on terrain rendering using ROAM, a complex TIN-based algorithm using continuous triangle-bintree meshes to achieve dynamic on-thefly visualization; good biblio]

Duckson, D.W. Jr., and Duckson, L.J., 2001, Channel bed steps and pool shapes along Soda Creek, Three Sisters Wilderness, Oregon: Geomorphology, v. 38, nos. 3-4, p. 267-279. [no lithologic var. by step height $\mathrm{h} / \mathrm{slope},(\mathrm{L} / \mathrm{h}) / \mathrm{slope}$, etc.]

Duh, J.-D., and Brown, D.G., 1999, Local reduction of systematic error in 7-1/2 minute DEMs by detecting anisotropy in derivative surfaces, Ch. 34 in Lowell, Kim, and Jaton, Annick, eds., Spatial Accuracy Assessment—Land Information Uncertainty in Natural Resources: Chelsea, MI, Ann Arbor Press, p. 281-292. [fix DEM 'stripes'; use semivariograms \& fractal D; local better than global smoothing; some info loss] 
Dumoulin, C., Doin, M.P., and Fleitout, L., 2001, On the interpretation of linear relationships bwteen seafloor subsidence rate and the height of the ridge: Geophysical Journal International, v. 146, no. 3, p. 691-698. [bathymetric spectrum; age/depth; ridge height/seafloor depth autocorrel.]

Dunn, Matthew and Hickey, R.J., 1998, The effect of slope algorithms on slope estimates within a GIS: Cartography (Canberra), v. 27, no. 1, p. 9-15; http://www.mappingsciences.org.au/journal.htm. [tried 4 techniques; max. downhill gradient calcs. are best]

Dunn, R.A., Scheirer, D.S., and Forsyth, D.W., 2001, A detailed comparison of repeated bathymetric surveys along a 300-km-long section of the southern East Pacific Rise: Journal of Geophysical Research, v. 106, no. B1, p. 463-471. [spectral analysis, depth differences, size/height threshold]

Dupuis-Torcy, 1st name unknown, and Brisson, Barnabé, 1808, Sur l'art de projecter les canaux de navigation (in French; on locating canals): Journal de l'Ecole Polytechnique, cah. 14, no. 7, p. 262288; republished 1829 as Un essai sur l'art de projeter les canaux à point de partage (planning canals linking different drainage basins) in Brisson, B., Essai sur le système général de navigation intérieure de la France, paging unknown. [remarkable paper; defined watercourses geometrically as lines of steepest descent which are asymptotically approached by other lines of steepest descent; cited by Müller 1919 (also 1908/12?), \& later Rieger 1997 (\& thence López 1997) as possibly defining drainage lines analytically (altho no math shown) before their mention by SaintVenant 1852. Shows how best line for any summit level may be laid out from topographic maps (then in infancy), particularly those of Cassini (?), rather than ground surveying. N.B. France pioneered the engineering of modern canals, which could follow either terrain contours (earlier in the 1760-1840 Canal Age) or a straight line (later); if contours, few expensive earthworks \& locks were needed, but resulting route was longer \& less direct; the descriptive work reported here led to more accurate cost estimates for cut-\&-fill of canals linking different watersheds. See Brisson 1829; Dupuis-Torcy was a civil engineer; a canal he designed in 1804 in Cayenne (Fr. Guyana, where died ca. 1808) is named for him]

Durheim, C.J., 1850, Sammlung trigonometrischer oder barometrisch-bestimmter absoluter Höhen der Schweiz und ihrer näheren Umgebung. Hypsométrie de la Suisse et des Etats voisins: Bern, Haller, 706 p. [big compilation of trig. \& barom. heights; hypso. of Switzerland \& adjoining States]

Dutton, G.H., 1999, A hierarchical Coordinate System for Geoprocessing and Cartography: Berlin, Springer, Lecture Notes in Earth Sciences 79, 231 p. [monograph on digital map-generalization; 1997-98 Ph.D. diss., U. Zürich]

\section{$\mathbf{E}$}

East, T.J., 1978, Mass movement landforms in Baroon Pocket, south-east Queensland-a study of form and process: Queensland Geographical Journal, ser. 3, v. 4, July, p. 37-67. [L, W, d, d/L, vol., \& slope gradient differ among 5 types (99 landslides); slope map]

Eastman, Ronald, 1992, IDRISI version 4.0, User's Guide: Worcester, MA, ClarkLabs, Clark University, 178 p. [world's most-used GIS]

Eastman, Ronald, 2002, idrisi32: Worcester, MA, ClarkLabs, Clark University; http://www.clarklabs.org/ldrisiSoftware.asp?cat=2. [major upgrade of world's most-used GIS, \$600-\$1500]

Ebert, Hermann, 1890, Über die Ringgebirge des Mondes (in German): Sitzungsberichte der Physikalische-Medizinische Soc., Erlangen, p. 171-191. [major pub. on 'Ebert's Rule'; measured crater diams. \& depths; computed Schröter's ratio for 92 craters $13 \mathrm{~km}<\mathrm{D}<150 \mathrm{~km}$ (most rim vol. $<$ bowl)]

Ebisemiju, F.S., 1976, Morphometric work with Nigerian topographical maps: Nigerian Geographical Journal (Ibadan), v. 19, no. 1, p. 65-77. [air photos, drainage patterns, methods, slopes] 
Ebisemiju, F.S., 1986, Environmental constraints on the interdependence of drainage basin morphometric properties, in Gardiner, V., ed., International Geomorphology 1986, Part II: New York, John Wiley \& Sons, p. 3-20. [correl. \& PCA of 30 var.: texture (max), size, relief, link length ratio, shape, bifurcation ratio]

Eckhardt, F.D., Wilkinson, M.J., and Lulla, K.P., 2000, Using digitized handheld Space Shuttle photography for terrain visualization: International Journal of Remote Sensing, v. 21, no. 1, p. 1-5. [70mm color pic (Namib inselberg) draped on GTOPO30 DEM; res $=50 \mathrm{~m} \pm 5.3 \mathrm{~m}$ ]

Eckis, Rollin, 1928, Alluvial fans of the Cucamonga District, southern Arizona: Journal of Geology, v. 36 , no. 3, p. 224-247. [early quant. obs., concavity \& slope diminish w/ increasing fan size]

Economic Planning Agency, 1969, Topographic relief of Japan (in Japanese): map scale $1 / 1,160,000 . \quad$ [relief energy defined on 1 ' $x$ 1.5' lat.-lon. grid]

Edwards, R., and Durkin, J., 1969, Computer prediction of service areas for V.H.F. mobile radio networks: Proceedings of the Institution of Electrical Engineers (IEE, UK), v. 116, no. 9, p. 14931500. [early advocates of regular-grid DEMs fr topo maps for intervisibility \& radio-path loss algorithms]

Edwards, S.F., and Wilkinson, D.R., 1982, The surface statistics of a granular aggregate: Proceedings of the Royal Society of London, v. A381, no. 1780, p. 17-31. [acc. to PastorSatorras \& Rothman 1998a, adds uncorrel. noise to diffusion eqn. to get true self-affine surface]

Ehrenburg, Karl, 1891, Studien zur Messung der horizontalen Gliederung von Erdräumen (in German; ... measuring spatial arrangement of areas on the Earth): Würzburg, Verhandlungen der Physikalisch-Medicinischen Gesellschaft zu Würzburg, v. 25, no. 2, 44 p. [reviews the problem fr Ritter 1828 to C. Rohrbach 1890; considers geometry of var. shape-meas. in great detail]

Elkie, P.R., Rempel, R.S., and Carr, A.P., 1999, Patch Analyst User's Manual-a tool for quantifying landscape structure: Thunder Bay, Ontario, Ontario Ministry of Natural Resources, Northwest Science and Technology, Technical Manual TM-002, 16 p. +Appendix; http://sevilleta.unm.edu/technology/reference/esri/patch_habitat/nwtm002.pdf. [program can implement FRAGSTATS in grid format; http://flash.lakeheadu.ca/ rrempel/patch/]

Ellenberg, Ludwig, 1969, Versuch der numerischen Erfassung des Reliefcharakters (in German; Attempt at numerical expression of relief character): Geographica Helvetica (Bern), v. 24, no. 1, p. 13-15. [slope, relief energy, stream density, contour density]

Elliott, F.E., 1953, A technique of presenting slope and relative relief on one map: Surveying and Mapping, v. 13, no. 4, p. 473-477. [G-H Smith relief on 2.5' squares \& 3 Raisz-Henry slope bins]

Elorza, M.G., and Martínez, V.H. Sesé, 2001, Multiple talus flatirons, variations of scarp retreat rates and the evolution of slopes in Almazán Basin (semi-arid central Spain): Geomorphology, v. 38, nos. 1-2, p. 19-29. [math. fcns. for 12 concave slope profiles at 5 diff. evol. stages]

Embleton, Clifford, and Hamann, C., 1988, A comparison of cirque forms between the Austrian Alps and the Highlands of Britain: Zeitschrift für Geomorphologie, Supplementband 70, p. 75-93. [n= 302 fr $1 / 25 \mathrm{~K}$ maps; L/h, wall/floor \& closure angles, azimuth; results not clear-cut]

Emery, K.O., 1958, Shallow submerged marine terraces of southern California: Bulletin of the Geological Society of America, v. 69, no. 1, p. 39-60. [chart (Plate I) stores/displays depths for discontinuous terrace profiles]

Endreny, T.A., and Wood, E.F., 2001, Representing elevation uncertainty in runoff modelling and flowpath mapping: Hydrological Processes, v. 15, no. 12, p. 2223-2236. [var. sensitivity of D8, MF, DEMON-e \& -b, D-Infinity, \& DEMON-bI to DEM error] 
Endreny, T.A., Wood, E.F., and Lettenmaier, D.P., 2000, Satellite-derived digital elevation model accuracy-hydrogeomorphological analysis requirements: Hydrological Processes, v. 14, no. 1, p. 1-20. [overall SPOT/USGS' differences $<3 \%$, but USGS $7.5^{\prime}$ better at scales $<100 \mathrm{~m}$ ]

Endreny, T.A., Wood, E.F., and Hsu, Ann, 2000, Correction of errors in SPOT-derived DEM's using GTOPO30 data: IEEE Transactions on Geoscience and Remote Sensing, v. 38, no. 3, p. 12341241. [coarser GTOPO30 useful in error-analysis of finer satellite-derived DEM]

Engelen, G.B., and Huybrechts, Willy, 1981, A comparison of manual and automated slope maps: Catena, v. 8, no. 2, p. 239-249. [made a DEM; manual (moving interval) method better where detail required]

Environmental Systems Research Institute (ESRI), Inc., 1997, Watershed Delineator Application User's Manual: Redlands, CA, ESRI, paging unknown. [the DEM-to-watershed transformation is incorporated into ESRI software]

Etzelmüller, Bernd, and Björnsson, Helgi, 2000, Map analysis techniques for glaciological applications: International Journal of Geographical Information Science, v. 14, no. 6, p. 567-581. [calc. basal shear stress, vel., drains, \& water vol. fr DEM of Iceland ice cap]

Etzelmüller, Bernd, Ødegård, R., Berthling, I., and Sollid, J.L., 2001, Terrain parameters and remote sensing data in periglacial research: Permafrost and Periglacial Processes, v. 12, no. 1, p. 79-92. [if spatial relations scale-independent within certain range, info can be scaled up \& down]

Evans, I.S., 1999, Was the cirque glaciation of Wales time-transgressive or not?: Annals of Glaciology, v. 28, p. 33-39. [no; regression eqns. show floor altitude increases to $\mathrm{N}$ or $\mathrm{NE}$, as expected fr present conditions]

Evans, I.S., and Cox, N.J., 1998, Relations between land surface properties-altitude, slope and curvature, in Hergarten, Stefan, and Neugebauer, H.J., eds., Process Modelling and Landform Evolution (Lecture Notes in Earth Science, 78): Berlin, Springer, p. 13-45. [complements Evans 1998; more evidence that the land surface is not fractal]

Evans, K.G., and Willgoose, G.R., 2000, Post-mining landform evolution modelling 2. Effects of vegetation and surface ripping: Earth Surface Processes and Landforms: v. 25, no. 8, p. 803-823. [SIBERIA models changes to radioactive tailings pile that must remain undisturbed for $1000 \mathrm{~s}$ of years]

Everard, C.E., 1956, Erosion platforms on the borders of the Hampshire Basin: Transactions and Papers of the Institute of British Geographers, no. 22, p. $35 . \quad$ [elaborated the height-range diagram of Sparks 1949]

Eyles, R.J., 1971, Mass movement in Tangoio Conservation Reserve, northern Hawkes Bay: Earth Science Journal (NZ), v. 5, no. 2, p. 79-91. [52 valley-side profiles \& 29 landslide scars; profile relief, L, slope gradient (3-m segments), concavo-convexity]

Eyton, J.R., 1991, Rate-of-change maps: Cartography \& GIS, v. 18, p. 87-103. [calc. related elev. derivatives from finite differences]

F

Fagherazzi, Sergio, Bortoluzzi, Annalisa, Dietrich, W.E., Adami, Attilo, Lanzoni, Stefano, Marani, Marco, and Rinaldo, Andrea, 1999, Tidal networks 1. Automatic network extraction and preliminary scaling features from digital terrain maps: Water Resources Research, v. 35, no. 12, p. 3891-3904. [topo data from marsh \& tidal flats: threshold elev \& curvature; see also parts 2 and 3. p. 39053917 and 3919-3929] 
Fair, T.J.D., 1947, Slope form and development in the interior of Natal: Transactions of the Geological Society of South Africa, v. 50 (publ. 1948), p. 105-119. [profiles fr Abney level, readings to nearest $10^{\prime}$; slope segments $\left.1^{\circ}-35^{\circ}\right]$

Farabegoli, Enzo, and Agostini, Cecilia, 2000, Identification of Calanco, a badland landform in the northern Apennines, Italy: Earth Surface Processes and Landforms, v. 25, no. 3, p. 307-318. [contour crenulation ratio $(\mathrm{LO} / \mathrm{LF})=$ true length/length smoothed; hypso. integral]

Fardin, N., Stephansson, and Jing, Lanru, 2001, The scale dependence of rock joint surface roughness: International Journal of Rock Mechanics and Mining Sciences, v. 38, no. 5, p. 659-669. [fractal $\boldsymbol{D} \&$ amplit. $\boldsymbol{A}$ vary over 3-D laser-scanned windows $100 \mathrm{~mm}-1000 \mathrm{~mm}$ ]

Farr, Tom, and Kobrick, Mike, 2000, Shuttle radar topography mission produces a wealth of data: Eos, Transactions, American Geophysical Union, v. 81, no. 48, p. 583 \& $585 . \quad$ [how the SRTM data were gathered]

Farrenkopf, Dorothee, 1987, Das Relief als steuernder Parameter der Abflußdynamik-ein Beitrag zur fluvialen Prozeßforschung (Relief as controlling parameter of discharge dynamics-a contribution to fluvial process research): Zeitschrift für Geomorphologie, Supplementband 66, p. 73-82. [mean values don't predict high flows well]

Fatale, L.A., 1992, DCAC examines impact of DTED Levels 1- and 2 resolution on terrain visualization: U.S. Army Corps of Engineers, Topographic Engineering Center, Digital Data Digest, v. 2, no. 4, p. 1-4. [field photo/DEM images compared; Level 1 useless in gentle terrain, OK in many rough areas]

Favilli, Massimiliano, Innocenti, Fabrizio, Pareschi, M.T., Pasquarè, Giorgio, Mazzarini, Francesco, Branca, Stefano, Cavarra, Luciano, and Tibaldi, Alessandro, 1999, The DEM of Mt. Etna-geomorphological and structural implications: Geodinamica Acta (Paris), v. 12, no. 5, p. 279290. [ca. 30X40km; $5 \mathrm{~m}$ grid @ $\pm 1 \mathrm{~m}$ height accuracy; slope map \& histogram @ $1^{\circ}$ bins; $10^{6}$ input elevs.; shaded relief image]

Favis-Mortlock, David, 1998, A self-organizing dynamic systems approach to the simulation of rill initiation and development on hillslopes: Computers and Geosciences, v. 24, no. 4, p. 353-372; http://soilerosion.net/rillgrow/. [RillGrow, a simple DEM-based model using discrete packets for microtopo]

Favis-Mortlock, D.T., Boardman, John, Parsons, A.J., and Lascelles, Bruce, 2000, Emergence and erosion-a model for rill initiation and development: Hydrological Processes, v. 14, nos. 11-12, p. 2173-2205. [improved self-organizing DEM model, Rillgrow 2, applied to 4 soil surfaces]

Fedoseev, Yu.E., and Korolev, O.B., 1987, Determining the position of structural lines of topography by an analytic method (in Russian): Izvestiya Vysshikh Uchebnyh Zavedeny, Geodesiya i Aerophotosyemka, no. 1, p. 10-15. [no info]

Fekete, B.M., Vörösmarty, C.J., and Lammers, R.B., 2001, Scaling gridded river networks for macroscale hydrology - development, analysis, and control of error: Water Resources Research, v. 37, no. 7, p. 1955-1967. [algorithm rescales fine-resolution nets (fr HYDRO1k) to coarser res.; results for Europe]

Feldner, Hermann, 1902, Die Flussdichte und ihre Bedingtheit im Elbsandsteingebirge (drainage density \& its limitations ... ; in German): Mitteilungen des Vereins für Erdkunde zu Leipzig, p. 1-55. [early dd work post-Neumann 1900; describes 3 methods; $x=A / n ; A=$ basin area $\& n=$ number of segments] 
Felpeto, A., Araña, V., Ortiz, R., Astiz, M., and García, A., 2001, Assessment and modelling of lava flow hazard on Lanzarote (Canary Islands): Natural Hazards, v. 23, nos. 2-3, p. 247-257. [used number density of emission centers \& flowpaths fr 50m DEM]

Ferrarese, Francesco, Sauro, Ugo, and Tonello, Christian, 1998, The Montello Plateau-Karst evolution of an alpine neotectonic morphostructure: Zeitschrift für Geomorphologie, Supplementband 109, p. 41-62. [22 topo. parameters; got 2 groups of sub-units]

Ferretti, Alessandro, Prati, Claudio, and Rocca, Fabio, 1999, Multibaseline InSAR DEM reconstruction - the wavelet approach: IEEE Transactions on Geoscience and Remote Sensing, v. 37 , no. 2, p. 705-715. [selects weights in combining many uncorr. topo. profiles]

Fiedler, Bruno, 1890, Vergleich Orometrischer Methoden (Comparison of orometric methods as applied to the Thuringen Forest, in German): Friedrichs-Universität Halle-Wittenberg, InauguralDissertation (Ph.D.), 39 p, 5 plates. [Sonklar, Koristka, Penck, etc. for volume (Simpson's Rule best) \& ave. crest height $\&$ uplifted mass]

Fielder, Gilbert, 1962, The measurement of lunar altitudes by photography-l. Estimating the true lengths of shadows: Planetary and Space Science, v. 9, p. 917-928. [discusses all known error sources]

Fiilinskas, Gintautas, 1997, Baltijos Jüros Lietuvos kranto ilgis bei jo nustatymo problemos (in Lithuanian with English summary; length of the lithuanian shore of the Baltic Sea): Geografijos Metrastis (Geographical Yearbook; Vilnius. Lith.), v. 30, paging unknown. [used regression eqns. \& data fr maps, airphotos. field, cartometry (Volkov 1950 method); cites Keber 1864]

Fils, A.W., 1859, Die Centralgruppe des Thüringer Waldes oder die Gegend zwischen IImenau and Oberhof (in German): Petermanns Geographische Mitteilungen, v. 5, no. 6, p. 256-271, \& plate 10 $(1 / 60,000$ scale). $\quad$ [typical of Major Fils many careful surveys; detailed list describs each height; 100 ' contours over hachures]

Finlayson, Brian, and Statham, lan, 1980, Slope forms, chap. 6, in Sources and Methods in Geography: London UK \& Boston MA, Butterworths, p. 147-185. [slope freq. \& other quant. topics]

Finlayson, D.P., Montgomery, D.R., and Hallet, Bernard, 2002, Spatial coincidence of rapid inferred erosion with young metamorphic massifs in the Himalayas: Geology, v. 30, no. 3, p. 219-222. [geomorphic modeling; rate-of-erosion index, El, fr area, slope \& precip., fr GTOPO30 for 16 major basins]

Fioole, A., Houwing, E.J., and van der Heijdt, L.M., 1997, SURFIS—a tool for designing and optimizing dredging schemes: Water Science and Technology, v. 37, p. 103-107. [allows DTM's to be produced with mapped random errors]

Fisher, P.F., 1994, Probable and fuzzy models of the viewshed operation, in Worboys, M.F., ed., Innovations In GIS I: London, Taylor \& Francis, p. 161-176. [DEM-based calculations]

Fisher, P.F., 1998, Improved modeling of elevation error with geostatistics: Geoinformatica, v. 2, no. 3 , p. 215-233. [stat \& spatial distr. of error; variograms of 50-m UK DEM]

Fleishmann, Erica, and Mac Nally, R.M., 2002, Topographic determinants of faunal nestedness in Great Basin butterfly assemblages-applications to conservation planning: Conservation Biology, v 16 , no. 2, p. 422-429. [no details other than terrain complexity is used]

Fleming, M.D., and Hoffer, R.M., 1979, Machine processing of Landsat MSS data and DMA topographic data for forest cover type mapping: West Lafayette, IN, Purdue, University, Laboratory 
for Applications of Remote Sensing, LARS Technical Report 062879, paging unknown. ['best method' (K.H. Jones, 1998) for computing slope fr DEM]

Flint, J.J., 1974, Stream gradient as a function of order, magnitude and discharge: Water Resources Research, v. 10, no. 5, p. 969-973. [link slope $=1 /$ link magnitude]

Florinsky, I.V., 2000, Relationships between topographically expressed zones of flow accumulation and sites of fault intersection-analysis by means of digital terrain modeling: Environmental Modelling Software, v. 15, no. 1, p. 87-100. [apply Shary 1995 DEM-based technique to better predict soil salinization]

Florinsky, I.V., 2002, Errors of signal processing in digital terrain modelling: International Journal of Geographical Information Science, v. 16, no. 5, p. 475-501. [3 types; Gibbs phenom., noise fr DEM differentiation, \& displacement of grid]

Florinsky, I.V., Eilers, R.G., and Lelyk, G.W., 2000, Prediction of soil salinity risk by digital terrain modelling in the Canadian prairies: Canadian Journal of Soil Science, v. 80, no. 3, p. 455-463. [accum. \& dissipat. zones fr DEM curvature used to improve predictive maps]

Florinsky, I.V., Eilers, R.G., Manning, G., and Fuller, L.G., 2002, Prediction of soil properties by digital terrain modelling: Environmental Modelling and Software, v. 17, p. 295-311. [DEM slope, aspect, curv., basin A, topo. \& stream power indices \& correl. of soil and topo.]

Florinsky, I.V., and Kuryakova, G.A., 2000, Determination of grid size for digital terrain modelling in landscape investigations-exemplified by soil moisture distribution at a micro-scale: International Journal of Geographical Information Systems, v. 14, no. 8, p. 815-832. [experimental method uses correlation analysis to optimize spacing]

Flowers, G.E., and Clarke, G.K.C., 1999, Surface and bed topography of Trapridge Glacier, Yukon Territory, Canada-digital elevation models and derived hydraulic geometry: Journal of Glaciology, v. 45 , no. 149 , p. $165-174$. [upstream area fr. DEM fr. ice-penetrating radar \& statist. 'preconditioning']

Fluck, Rudolf, 1925, Die Flussdichte im schweizerisch-französischen Jura (in German): InauguralDissertation, Univ. Basel, 89 p., Verhandlungen der Naturf. Gesellschaft, in Basel, Emil Birkhäuser \& Cie., v. 37, p. $120-218$. [1:500K maps of Jura Mtn. drainage density \& mean stream spacing fr topo map data; dd values of all $40862-\mathrm{km}$ squares tabulated as $\mathrm{XY}$ array]

Flückiger, Otto, 1919, Morphologische Untersuchungen am Napf (in German), article 6, in Geologische Struktur der Schweizeralpen, Sammelband von 7 Schriften from 1889-1919: Zürich, 34 p. [calculated relative relief for (topographic) basins?]

Focardi, P., Garzonio, C.A., Sedda, E., and Vannocci, P., 1992, Relationship between morphometric parameters and lithological and geotechnical characteristics of unstable slopes in the Upper Valdarno basin, Tuscany, Italy, in Bell, D.H., ed., Landslides, International Symposium 6th, 10-14 February, Christchurch NZ, Proceedings: Rotterdam, Balkema, v. 2, p. 943-946. [180 slope profiles; freq. distr. \& 18 statistics on ea. lith. zone]

Fochler-Hauke, Gustav, 1941, Die Mandschurei (Manchuria, in German): Heidelburg, map 9. [1/1.7M relative-relief map (after Tada 1937); 10 relief intervals]

Fok, Yu-Si, 1971, Law of stream relief in Horton's stream morphological system: Water Resources Research, v. 7, no. 1, p. 201-203. [mean relief = semilog fnc. of stream order; eval. for 4 rivers]

Foster, G.R., and Wischmeier, W.H., 1974, Evaluating irregular slopes for soil loss prediction: Transactions of the American Society of Agricultural Engineers, v. 17, no. 2, p. 305-309. [attempts to adapt LS factor in USLE to irreg. topo; segments $\mathrm{w} /$ diff. slope] 
Foufoula-Georgiou, Efi, and Sapozhnikov, Victor, 2001, Scale invariances in the morphology and evolution of braided rivers: Mathematical Geology, v. 33, no. 3, p. 273-300. [philosophy, methods, \& examples from 4 rivers]

Fourneau, R., 1960, Contribution à l'étude des versants dans le sud de la Moyenne Belgique et dans le Nord de l'entre Sambre et Meuse. Influence de la nature du substratum (in French): Annales Société Géologique de Belgique, v. 84, p. 123-151. [10 areas; correl. valley depth \& mean slope; $5 \mathrm{~m}$ slope-sampling interval]

Fournier, F., 1960, Climat et Erosion (in French): Paris, P.U.F., 201 p. $\quad$ [pp. 139-150: 'orographic coefficient'; also, diff. hypso. curves can have same mean elev.]

Fraisse, C.W., Sudduth, K.A., and Kitchen, N.R., 2001, Delineation of site-specific management zones by unsupervised classification of topographic attributes and soil electrical conductivity: Transactions, American Society of Agricultural Engineers, v. 44, no. 1, p. 155-166. [TAPES-G pkg.; elev., slope (D8), plan \& profile curv., CTI; mapped PCs]

Francis, B., Green, M., and Payne, C., 1993, GLIM4-the statistical system for generalized linear interactive modeling: Oxford, Clarendon Press, 82 p. [pkg. combines continuous \& categorical variables in same analysis]

Francou, Bernard, and Manté, Claude, 1990, Analysis of the segmentation in the profile of alpine talus slopes: Permafrost and Periglacial Processes, v. 1, no. 1, p. 53-90. [35 slopes at 0.5 deg. precision, 10-m segments; new bi-phase model]

Franklin, W.R., 1973, Triangulated irregular network program: ftp://ftp.cs.rpi.edu/pub/franklin/tin73.targz. [early TIN algorithm]

Franklin, W.R., 1995, Compressing elevation data, in Egenhofer, M.J., and Herring, J.R., eds., Advances in Spatial Databases, Symposium on Spatial Data (SSD) 4th, Portland, ME, 6-9 August, Proceedings; Lecture Notes in Computer Science, v. 951: Berlin, Springer, p. 385-404; http://www.ecse.rpi.edu/Homepages/wrf/research/p/compress.pdf. [compares 24 techniques on one USGS 1:24K DEM, 5 on 24 DEMs, \& 3 on 10 ETOPO5 samples]

Franklin, W.R., 2000, Applications of analytical cartography: Cartography and Geographic Information Systems, v. 27, no. 3, p. 225-237;

http://www.ecse.rpi.edu/Homepages/wrf/research/gisapps/gisapps.pdf. [examples include terrain visibility, map overlay, mobility, interpol. \& approx. of curves \& terrain, etc.]

Franklin, W.R., 2000, Approximating visibility: International Conference on Geographic Information Science 1st, GIScience 2000, Savannah, GA, 28-31 Oct., Abstracts, p. 126; http://www.ecse.rpi.edu/Homepages/wrf/research/approxvis/index.html. [rel. importance of var. factors in visibility computation; vis. index sensitive to radius of interest \& is Poisson distr.; test on 24 USGS DEMs]

Franklin, W.R., 2002, GeoSpatial terrain-algorithms and representations: unpublished paper; http://www.ecse.rpi.edu/Homepages/wrf/research/geospatial.pdf; \& http://www.ecse.rpi.edu/Homepages/wrf/research/geospatial-talk-402/index.html. [explores var. grid DEM processing \& attempts at a unified philosophy]

Franklin, W.R., 2002, Siting observers on terrain: Spatial Data Handling 2002 Symposium, Ottawa, July 9, http://www.ecse.rpi.edu/Homepages/wrf/research/sitetalk/index.html; text at http://www.ecse.rpi.edu/Homepages/wrf/research/site.pdf. [new algorithm synth. fast viewshed \& LOS visibility index for mult. observers on level-1 DEM]

Franklin, W.R., and Gousie, M.B., 1999, Terrain elevation data structure operations, in International Cartographic Conference 19th \& General Assembly of the International Cartographic Association 
(ICA) 11th, Ottawa, Canada, Proceedings: v. 2, p. 1011-1020;

http://www.ecse.rpi.edu/Homepages/wrf/research/ica99/. [several programs; grid-TIN, visibility, compression, contour-grid interp.]

Franklin, W.R., and Said, Amir, 1996, Lossy compression of elevation data, in Kraak, M.-J., Molenaar, Martien and Fendel, E.M., eds., International Symposium on Spatial Data Handling, 7th, Delft, Neth., Proceedings: Edinburgh, Taylor \& Francis, v. 2, p. 519-531;

http://www.ecse.rpi.edu/Homepages/wrf/research/p/compress.pdf. [image compr. algorithm may be better \& simpler for DEMs than TIN; test on 24 USGS DEMs]

Franklin, W.R., Ray, C.K., and Mehta, Shashank, 1994, Geometric algorithms for siting of air defense missile batteries: Columbus OH, Battelle Inc., Contract no. DAAL03-86-D-0001, Technical Report, 129 p.; http://www.ecse.rpi.edu/Homepages/wrf/research/p/tec_report.pdf. [eval. 3 viewshed algorithms \& 4 visibility indices; algorithm for viewsheds better than simplistic sightline analysis]

Franz, J., 1899, Hohenschichten-Karte des Mondes (in German; contour map of the Moon): Astron. Beobacht. d. Königsburg, Sternwarte, v. 38, no. 75, paging unknown. [five 1200-m intervals; last such map until that of Ritter in 1934]

Franzen M., 1992, Das Digitale Geländehöhen-Modell von Österreich im Bundesamt für Eich- und Vermessungswesen (in German; DEM of Austria in the Federal Office for Calibration and Surveying): Vermessung, Photogrammetrie, Kulturtechnik (VPK/MPG), v. 90, p. 89-91. [the Austrian national DEM]

Frey, Herbert, Sakimoto, S.E.H., and Roark, J.H., 1998, The MOLA topographic signature at the crustal dichotomy boundary zone on Mars: Geophysical Research Letters, v. 25, no. 24, p. 44094412. [8 profiles; Elev. \& slope for different terrains; boundary $=2-4 \mathrm{~km}$ step fcn.]

Frey, Herbert, Sakimoto, S.E.H., and Roark, J.H., 1999, Discovery of a $450 \mathrm{~km}$ diameter, multi-ring basin on Mars through analysis of MOLA topographic data: Geophysical Research Letters, v. 26, no. 12 , p. $1657-1660$. [2km deep; fit rings to slope breaks in profiles; est. diams est. 350,455 , \& $670 \mathrm{~km}]$

Fried, J.S., Brown, D.G., Zweifler, M.O., and Gold, M.A., 2000, Mapping contributing areas for stormwater discharge to streams using terrain analysis, in Wilson, J.P., and Gallant, J.C., eds., Terrain Analysis-Principles and Applications, New York, John Wiley and Sons, p. 183-203. [var. results, parameters \& images from the TAPES software]

Friedrich, Klaus, 1996, Digitale Reliefgliederungsverfahren zur Abteilung bodenkundlich relevanter Flächeneinheiten (in German with English abstract; Digital relief classification methods for localizing soils-relevant units: Frankfurt an Main, Frankfurter Geowissenchaftliche Arbeiten, Serie D (Physische Geographie), no. 21 (Univ. Diss. 1995), 258 p. <http://www.rz.unifrankfurt.de/ relief/fga21/start.html>. [methods fr simple to multivar. stats. using slope, aspect, plan \& profile curv. fr Hesse DEM]

Friedrich, Klaus, 1998, Multivariate distance methods for geomorphographic relief classification, in Heineke H.J., Eckelmann W., Thomasson A.J., Jones R.J.A., Montanarella L., and Buckley B., eds., Land Information Systems-Developments for planning the sustainable use of land resources: Luxembourg, Office of the Official Publications of the European Communities, European Soil Bureau Research Report No. 4., EUR 17729 EN, p. 259-265.

$<$ http://www.bgr.de/N2/PROCEED/4_4.pdf>. [exemplifies methods fr simple to multivar. stats. using slope, aspect, plan \& profile curv. fr Hesse DEM]

Friesz, R.R., 1963, Desert terrain effects on vehicle performance, in Military Evaluation of Geographic Areas reports on activities to April 1963: Vicksburg, Mississippi, U.S. Army Corps of Engineers Waterways Experiment Station, Miscellaneous Paper no. 3-610, p. 60-72. [params. for test courses: cell size, relief, slope, elongation, parallelism, profile area, peakedness] 
Frisch, W., Székely, Kuhlemann, J., and Dunkl, I., 2000, Geomorphological evolution of the Eastern Alp in response to Miocene tectonics: Zeitschrift für Geomorphologie, v. 44, no. 1, p. 103-138. [elev. mean \& freq., slope map \& freq., R map (10km window) for diff. domains fr DEM]

Fu, Bojie, and Chen, Liding, 2000, Agricultural landscape spatial pattern analysis in the semi-arid hill area of the Loess Plateau, China: Journal of Arid Environments, v. 44, no. 3, p. 291-303. [patch size, fractal D, elong., diversity, dominance, relative richness, \& fragm. fr. land-use map]

Fujita, Takashi, 1984, Slope analysis of landslides of the soft rock type in Kinki, southwest Japan, in International Symposium on Landslides, 4th, 16-21 September, Toronto, Proceedings: Rexdale, Ont., Canadian Geotechnical Society, v. 2, p. 75-80. [spatial freq. of inventory rel. to slope; most deposits at $5^{\circ}-20^{\circ}$ ]

Furdada, Glòria, and Vilaplana, J.M., 1998, Statistical prediction of maximum avalanche run-out distances from topographic data in the western Catalan Pyrenees (northeast Spain): Annals of Glaciology, v. 26, p. 285-288. [regression eqns. for 3 profile classes fr 216 flow paths fr 1:50K map data]

\section{G}

Gallant, J.C., and Wilson, J.P., 2000, Primary topographic attributes, in Wilson, J.P., and Gallant, J.C., eds., Terrain Analysis-Principles and Applications: New York, Wiley, p. 51-85. [var. elev, aspect, slope, area, length, curv. fr DEMS \& TAPES software]

Gallant, J.C., Hutchinson, M.F., and Wilson, J.P., 2000, Future directions for terrain analysis, in Wilson, J.P., and Gallant, J.C., eds., Terrain Analysis-Principles and Applications: New York, Wiley, p. 523-527. [brief concluding remarks \& predictions, focused on TAPES]

Ganas, Athanassios, and Athanassiou, Evangelos, 2000, A comparative study on the production of satellite orthoimagery for geological remote sensing: Geocarto International, v. 15, no. 2, p. 51-59. [DEM fr SPOT images much like reference DEM fr 1/50,000 contours]

Gandolfi, C., and Bischetti, G.B., 1995, II valore dell'area di supporto nella generazione automatica della rete di drenaggio dai DEM: Idrotechnica, v. 3, p. 157-174. [criticizes DEM-to-watershed algorithms that use constant threshold area]

Gannett, Henry, collator \& arranger, 1877, Lists of Elevations Principally in That Portion of the United States West of the Mississippi River, 4th ed.: U.S. Department of the Interior, Miscellaneous Publications no. 1, Washington, D.C., 167 p. + map. [topo. results of the western surveys; large folding hypsometric map of U.S.]

Gao, Jay, 1997, Resolution and accuracy of terrain representation by grid DEMs at a micro-scale: International Journal of Geographic Information Science, v. 11, no. 2, p. 199-212. [spatial res. affects DEM's kriged from contours < threshold]

Garbrecht, Jurgen, Goodrich, D., and Martz, L.W., 1999, Methods to quantify distributed subcatchment properties from digital elevation models, in American Geophysical Union Annual Hydrology Days, 19th, 16-20 August, Fort Collins, CO: Proceedings, p. 149-160. [est. basin length \& slope directly fr DEM, not maps]

Garbrecht, Jurgen, and Martz, L.W., 2000, Digital elevation model issues in water resources modeling, paper 1 in Djokic, Dean, and Maidment, David, eds., Hydrologic and Hydraulic Modeling Support with Geographic Information Systems: Redlands CA, ESRI Press, p. 1-28, also http://www.esri.com/library/userconf/proc99/proceed/papers/pap866/p866.htm. [reviews DEM-towatershed transformation state-of-art, esp. data quality \& sub-catchment properties] 
Garbrecht, Jurgen, Ogden, F.L., DeBarry, P.A., and Maidment, D.R., 2001, GIS and distributed watershed models. l-data coverages and sources: Journal of Hydrologic Engineering, v. 6, no. 6, p. 506-514. [1st of 2-part GIS tutorial for practicing engineers]

Garcia-Castellanos, Daniel, 2002, Interplay between lithospheric flexure and river transport in foreland basins: Basin Research, v. 14, no. 2, p. 89-104. [3-D quant. model of various processes along drainage net]

García-Ruiz, J.M., Gómez-Villar, Amelia, Ortigosa, Luis, and Martí-Bono, Carlos, 2000, Morphometry of glacial cirques in the central Spanish Pyrenees: Geografiska Annaler, v. 82 A, no. 4, p. 433-442. [elev., aspect, lithology A, W, L, L/W. etc.; elev. explains most of variance]

Garcia-Zuniga, F., and Parrot, J.-F., 1998, Tomomorphometric analysis of a recent volcanic cone-Misti (Peru): C.R. Acad. Sci. (Paris), v. 327, p. 457-462. [pattern-recognition extraction of a surface feature from DEM]

Gardner, J.V., Mayer, L.A., and Hughes Clark, J.E., 2000, Morphology and processes in Lake Tahoe: Geological Society of America Bulletin, v. 112, no. 5, p. 736-746. [L, W, H, \& dist. fr headwall of 113 avalanche blocks on \& off debris apron]

Gardner, J.V., Dartnell, Peter, Mayer, L.A., and Hughes Clarke, J.E., 2000a, Bathymetry and selected perspective views of sea floor north and west of Maui, Hawaii: U.S. Geological Survey, Water-resources Investigations Report 00-4046, map scale 1/100,000. [superior visualization at $20 \mathrm{~m} /$ pixel, <http://walrus.wr.usgs.gov/outreach/seamap/>]

Gardner, J.V., Dartnell, Peter, Mayer, L.A., Hughes Clarke, J.E., and Stone, J.C., 2000b, Bathymetry and selected perspective views of central San Francisco Bay, California: U.S. Geological Survey, Water-resources Investigations Report 00-4146, map scale 1/15,000, $<$ http://walrus.wr.usgs.gov/outreach/seamap/>. [superb visualization detail at $4 \mathrm{~m} /$ pixel]

Gardner, W.H., 1948, Determination of the critical stream for various slopes: Soil Science, v. 66, no. 3, p. 205-215. [experiments confirm soil erosion = fcn (irrigating stream size \& surface slope)]

Gardoll, S.J., Groves, D.I., Knox-Robinson, C.M., Yun, G.Y., and Elliott, N., 2000, Developing the tools for geological shape analysis, with regional- to local-scale examples from the Kalgoorlie Terrane of Western Australia: Australian Journal of Earth Sciences, v. 47, no. 5, p. 943-953. [general $X Y$ shape analysis, also applic. to landforms]

Garnett, Alice, 1935, Insolation, topography, and settlement in the Alps: Geographical Review, v. 25, no. 4, p. 601-617. ['intensity maps' fr terrain, Sun, \& Sun/valley-axis angles fr $4 \mathrm{~mm}$ grid on topo map]

Garrison, W.L., and Marble, D.F., eds., Quantitative Geography, Part I-Economic and Cultural Topics, and Part II-Physical and Cartographic Topics: Evanston, III., Northwestern University Studies in Geography, nos. 13 and 14, 288 p. and 324 p. [unconscionably delayed publication of 17-paper proceedings of seminal ONR/NAS/NRC-sponsored May 1960 symposium that should have had far greater impact than it did. (this meeting closely followed the AAAS-sponsored Dec. 1959 symposium on Quantitative Terrain Studies, which failed to result in a proceedings)]

Garvin, J.B., and Frawley, J.J., 1998, Geometric properties of Martian impact craters-preliminary results from the Mars Orbiter Laser Altimeter: Geophysical Research Letters, v. 25, no. 24, p. 44054408. [n=98; simple/complex: $d=0.14 D^{0.90} \& d=0.25 D^{0.49}$; also X-sect.]

Garvin, J.B., Sakimoto, S.E., Frawley, J.J., and Schnetzler, C., 2000, Geometric properties of Martian impact craters-an assessment from the Mars Orbiter Laser Altimeter (MOLA) digital elevation model (abs.): Lunar and Planetary Science XXXI, Abstract 1619, CD-ROM. $\quad[7 \mathrm{~km} \leq \mathrm{D} \leq 100 \mathrm{~km}$; complex, $d=0.33 D^{0.53 \pm 0.03}$ ] 
Gasparini, N.M., Tucker, G.E., and Bras, R.L., 1999, Downstream fining through selective particle sorting in an equilibrium drainage network: Geology, v. 27, no. 12, p. 1079-1082. [simulations with GOLEM model of landscape evolution (Tucker \& Slingerland, 1997)]

Gatto, Francesco, and Marocco, Ruggero, 1994, Morfometria e geometria idraulica dei canali della Laguna di Grado (Friuli-Venezia Giulia) (in Italian; Morphometry and hydraulic geometry of channels of the Grado Lagoon, Friuli-Venezia Giulia): Geografia Fisica e Dinamica Quaternaria (Torini), v. 16, no. 2, p. 107-119. [channel geometry, drainage pattern, lagoons, morphometry]

Gay, S.P., 1962, Origen, distribucíon y movimiento de las arenas eólicas en el área de Yauca a Palpa: Boletin de la Sociedad Geologica del Perú, v. 37, p. 37-58. [good early quant. obs. on airphotos. buried in obscure journal]

Gay, S.P., Jr., 1999, Observations regarding the movement of barchan sand dunes in the Nazca to Tanaca area of southern Peru: Geomorphology, v. 27, nos. 3-4, p. 279-293. [transl. 1962 paper; quantified Bagnold's size/speed deduction. etc.; $3 \mathrm{~h}$ meas.: h/w not 1/10]

Gee, M.D., 1992, Classification of hazard zonation methods and a test of predictive capability, in Bell, D.H., ed., Landslides, International Symposium 6th, 10-14 February, Christchurch NZ, Proceedings: Rotterdam, Balkema, v. 2, p. 947-952. [18 types of zonation; quant. index for 9 diff. schemes finds similar susceptibilities in test]

Geikie, Archibald, 1868, On denudation now in progress: Geological Magazine, v. 5, p. 249-254. [used Humboldt's mean continental heights; argued landforms were recent; see Vacher 1999]

Geldern-Crispendorf, Günther von, 1932, Reliefenergie, in Geisler, W., ed., Wirtschafts- und Verkehrsgeogr. Atlas von Schlesien: Breslau, 1/750K map. [map of relief 'energy'; 8 relative-relief intervals]

Gens, Rüdiger, 1999, SAR interferomtry-software, data format, and data quality: Photogrammetric Engineering and Remote Sensing, v. 65, no. 12, p. 1375-1378. [helpful state-of-art summary, esp, on DEM quality]

Gerber, Paul, 1927, Morphologische Untersuchungen am Alpenrand zwischen Aare und Saane (Freiburger-Stufenlandschaft) (in German): Univ. Freiberg (Switz.), Dissertation, 66 p., Mitteilungen der Naturforschenden Gesellschaft des Kantons Freiberg, Série Géologie et Géographie, v. 10, no. 2, p. 125-197. [char. valley shape using incremental surface curves (elev. vs area), or Flächenzuwachskurve, for 41 areas betw $570 \mathrm{~m} \& 2160 \mathrm{~m}]$

Gerrard, A.J. and Gardner, R.A.M., 2000, The role of landsliding in shaping the landscape of the Middle Hills, Nepal: Zeitschrift für Geomorphologie, Supplementband 122, p. 47-62. [maps of slope (6 classes), \& slope-morphology (the 9 classes); failure $\mathrm{V}, \mathrm{W}$, slope]

Gesch, D.B., 1998, Accuracy assessment of a global elevation model using Shuttle Laser Altimeter data, in IEEE International Geoscience and Remore Sensing symposium (IGARSS), Seattle WA, July 6-10, Proceedings: Piscataway NJ, Institute of Electrical and Electronic Engineers, CD-ROM. [365,000 SLA points; overall vertical RSME = (only) $70 \mathrm{~m}$ for GTOPO30]

Gesch, D.B., 1999, The effects of DEM generalization methods on derived hydrologic features, Ch. 31 in Lowell, Kim, and Jaton, Annick, eds., Spatial Accuracy Assessment-Land Information Uncertainty in Natural Resources: Chelsea, MI, Ann Arbor Press, p. 255-262. [breakline emphasis helps preserve topo structure when generalizing]

Gesch, D.B., and Larson, K.S., 1998, Techniques for development of global 1-kilometer digital elevation models, in Pecora Thirteen, Human Interactions with the Environment-Perspectives from Space, 13th, Sioux Falls, SD, August 20-22, 1996, Proceedings: Bethesda, MD, American Society of Photogrammetry and Remote Sensing, CD-ROM; also 
<http://edcwww.cr.usgs.gov/landdaac/gtopo30/papers/geschd3.html>. [details on GTOPO30 source datasets and processing]

Gesch, D.B., Oimoen, M.J., Greenlee, S.K., Nelson, Charles, Steuck, Michael, and Tyler, Dean, 2002, The National Elevation Dataset: Photogrammetric Engineering and Remote Sensing, v. 68, no. 1, p. 5-11; http://gisdata.usgs.net/ned/default.htm. [NED, seamless \& continually upgraded $30 \mathrm{~m}$ DEM fr all 1:24K USGS quads eliminates tiling \& preprocessing]

Gesch, D.B., Verdin, K.L., and Greenlee, S.K., 1999, New land surface digital elevation model covers the Earth: Eos, Transactions, American Geophysical Union, v. 80. no. 6, p. 69-70; http://edcdaac.usgs.gov/gtopo30/README.html\#h9. [GTOPO30, @ 1km grid spacing, replaces ETOPO5]

Gessler, P.E., 1996, Statistical soil-landscape modelling for environmental management: Centre for Resource and Environmental Studies, Australian National University, unpublished Ph.D. thesis, 228 p. [no info]

Ghosh, Parthasarathi, 2000, Estimation of channel sinuosity from paleocurrent data-A method using fractal geometry: Journal of Sedimentary Research, v. 70, no. 3, p. 449-455. [meanderpattern sinuosity related to dispersion of segment orientations]

Giese, B., Oberst, J., Roatsch, T., Neukum, G., Head, J.W., and Pappalardo, R.T., 1998, The local topography of Uruk Sulcus and Galileo Regio obtained from stereo images: Icarus, v. 135, no. 1, p. 303-316. [Ganymede fr. Galileo mission: DEMs @ 0.5 \&1.0 km; topo profiles; primitive simplecrater $\mathrm{d} / \mathrm{D}]$

Giglierano, J.D., 1999, Shaded relief map of lowa: lowa Geology, no. 24, p. 14-15. [color; quite good portrayal of putatively 'flat' state]

Gilbert, G.K., 1877, Land Sculpture, p. 99-150 in Report on the Geology of the Henry Mountains: U.S. Geographical and Geological Survey of the Rocky Mountain Region, Washington, D.C., U.S. Govt. Printing Office, 160 p.; p. 93-144 in 2nd ed., 1880 (170 p.). [seminal; establishes what to measure; Gilbert's 'law of divides' (116-17,110-11) - '... profile of a river (is) a curve concave upward with the greatest curvature at the upper end' Fig. 54 is logarithmic-like profile; 'declivity bears an inverse relation to quantity of water' $(113-14,108)$-i.e., not sediment size as asserted by Sternberg 1875]

Gilbert, G.K., 1914, The transportation of debris by running water: U.S. Geological Survey, Professional Paper 86, 263 p. [measured slope of sediment in flume \& related it to other data]

Giles, P.T., 2001, Remote sensing and cast shadows in mountain terrain: Photogrammetric engineering and Remote Sensing, v. 67 , no. 7, p. 833-839. [algorithm to delineate shadows automatically is $86 \%$ effective]

Giles, P.T., and Franklin, S.E., 1996, Comparison of derivative topographic surfaces of a DEM generated from stereoscopic SPOT images with field measurements: Photogrammetric Engineering and Remote Sensing, v. 60, no. 10, p. 1165-1171. [raw DEM not good; test used slope, incidence (from aspect), \& profile curvature]

Gilg, A.W., 1973, A note on slope measurement techniques: Area (London), v. 5, no. 2, p. 114-117. [inclined-angle tacheometry, using theodolite \& staff; need common test areas]

Gimel'farb, G.L., Schmidt, Jochen, and Braunmandl, A., 1999, Gibbs fields with multiple pairwise interactions as a tool for modelling grid-based data, in Hergarten, St., and Neugebauer, H.J., eds., Process Modelling and Landform Evolution, Lecture Notes in Earth Sciences 78: Berlin, SpringerVerlag, p. 47-73. [complex DEM processing reproduces Hammond types in 2 areas; inconclusive] 
Giusti, E.V., and Schneider, W.J., 1965, The distribution of branches in river networks U.S. Geological Survey Professional Paper 422-G, p. G1-G10. [found unexpected variability in analysis of bifurcation ratios]

Glagolev, A.A., 1933, On geometrical methods of quantitative mineralogic analysis of rocks (in Russian): Transactions of the Institute of Econ. Mineralogy, Moscow, v. 59, p. 1-47 (not p. 147?). [simplifies Rosiwal 1898 approach to area sampling by replacing lines with grid points]

Glanz, James, 1999, Physicists invading geologists' turf: New York Times SCIENCE, November 23, p. D1, D4. [layman's summary of math./theor. approach to geomorph. by Rinaldo, Rodriguez-Iturbe etc.]

Glazyrin, G.Ye., 1978, Identification of surging glaciers by morphometric characteristics: Mater. Glyatsiologicheskikh Issled. Khronika, v. 33, p. 136-138. [univariate analysis only]

Glezer, V.L., 1988, Development of methods and techniques for derivation and application of digital terrain model to generation of special agricultural maps (abs, Ph.D. thesis; in Russian): Moscow Institute of Engineers for Land Management, Moscow, 24 p. [no info]

Glock, W.S., 1931, The development of drainage systems-a synoptic view: The Geographical Review, v. 21, no. 4, p. 475-482. [uniform drainage density implies constant mean river-spacing, which suggests channel network has reached max. extension into an area]

Gloriod, A., and Tricart, Jean, 1952, Étude statistique de vallées asymétriques sur la feuille Saint-Pol au 1/50 000 (in French): Revue de Géomorphologie Dynamique, v. 3, no. 2, p. 88-98.

[constructed rose diagram showing valley asymmetry]

Goldie, H.S., and Cox, N.J., 2000, Comparative morphometry of limestone pavements in Switzerland, Britain and Ireland: Zeitschrift für Geomorphologie, Supplementband 122, p. 85-112. [freq. of clint (block) L \& W \& L/W, grike (pit) W \& d \& d/W]

Goller, A., Gelautz, M., and Leberl, F., 1999, Parallel image processing applied to radar shape-fromshading: Photogrammetric Engineering and Remote Sensing, v. 65, no. 3, p. 259-267. [handles large images; 14 processors speed up s-f-s by 13X]

Gong, Jianya, Li, Zhilin, Zhu, Qing, Sui, Haigang, and Zhou, Yi, 2000, Effects of various factors on the accuracy of DEMs-an intensive experimental investigation: Photogrammetric Engineering and Remote Sensing, v. 66, no. 9, p. 1113-1117. [accuracy = f(sampling interval, specific features, relief, data model, capture method)]

Gönnenwein, M.-L., 1931, Untersuchungen über die Flußdichte schwäbischer Landschaften: Erdgesch. u. landeskdl. Abh. aus Schwaben u. Franken, Öhringen, Schwend, v. 13, 66 p. [drainage density, calc. fr. topo maps, shown by density of dot patterns]

Goodchild, M.F., Steyaert, L.T., Parks, B.O., Johnston, Carol, Maidment, D.R., Crane, Michael, and Glendinning, Sandi, eds., 1996, GIS and Environmental Modeling-Progress and Research Issues: New York, Wiley, 504p. [many brief applications papers, some incorporating morphometry]

Goovaerts, P., 1999, Using elevation to aid the geostatistical mapping of rainfall activity: Catena, v. 34 , nos. 3-4, p. 227-242. [DEM helps materially; good results from cokriging]

Goovaerts, P., 2000, Geostatistical approaches for incorporating elevation into the spatial interpolation of rainfall: Journal of Hydrology. v. 228, nos. 1-2, p. 113-129. [DEM, multivariate geostatistics, Kriging]

Gordon, D.L., 1960, A morphometric analysis of selected lowa drainage basins: lowa City, IA, University of lowa, unpublished MA thesis, 193 p. [drainage basins, patterns, var. morphometry] 
Goudie, A.S., 1978, Colonel Julian Jackson and his contribution to geography: Geographical Journal, v. 144, p. 264-270. [more on the J.R. Jackson 1834 stream ordering, etc.]

Goudie, Andrew, Stokes, Stephen, Cook, James, Samieh, S., and El-Rashidi, O.A., 1999, Yardang landforms from Kharga Oasis, south-western Egypt: Zeitschrift für Geomorphologie, Supplementband 116, p. 97-112. [L, W, H, azimuth, V stats \& histogr.; H/w, L/H, V/H, V/W eqn.]

Gousie, M.B., 1998, Contours to digital elevation models-grid-based surface reconstruction methods: Ph.D. thesis, Electrical, Computer, and Systems Engineering Dept., Rensselaer Polytechnic Institute, Troy, NY, paging unknown. [improves representation over 'thin-plate' model?]

Gousie, M.B., and Franklin, W.R., 1998, Converting elevation contours to a grid, in Spatial Data Handling '98 Conference, 11-15 July, Vancouver, BC, Proceedings: p. 647-656; http://www.ecse.rpi.edu/Homepages/wrf/research/p/contour.pdf. [new methods; 1st repeatedly interpolates lines betw. orig. contours; 2nd starts w any interp. or approx. surface, gets gradient lines, \& does spline interp.]

Gout, Christian, and Komatitsch, Dimitri, 2000, Surface fitting of rapidly varying data using rank coding-application to geophysical surfaces: Mathematical Geology, v. 32, no. 7, p. 873-888. [scale transformation $\mathrm{w} /$ pre- \& post-processing = superior to splines; volcano DEM]

Grabau, W.E., 1958, Derivation of a numerical description of the generalized plan and profile: office memorandum to Chief, Geology Branch, U.S. Army Engineer Waterways Experiment Station, Vicksburg, unpublished manuscript, 14 July, 7 p. [the char. PPL (here GPPL) was defined in Dec. 1957 'Resumé' doc.; this memo revised as appendix to Van Lopik \& Kolb 1959]

Graff, L.H., 1997, State-of-the-art terrain analysis capabilities for today's army: ACSM/ASPRS Annual Convention and Exposition, Seattle, WA, 7-10 April, Technical Papers, v. 3, p. 716-725. [no info]

Graham, L.C., 1980, Stereo radar for mapping and interpretation, in Radar geology-an assessment, report of the Radar Geology Workshop, Snowmass, CO, 16-20 July 1979, Jet Propulsion Laboratory Publication 80-61, p. 336-350. [introduction to radargrammetry for terrain heights]

Graham, S.E., and Pike, R.J., 1998a, Elevation maps of the San Francisco Bay region, California-a digital database: U.S. Geological Survey Open-File Report 98-625, 17 p., scale 1:125,000; http://wrgis.wr.usgs.gov/open-file/of98-625/index.html. [data \& printer plots fr new DEM of ca. 24 $M$ elevs spaced at $30 \mathrm{~m} \&$ mosaicked from 1:24K quad. DEMs]

Graham, S.E., and Pike, R.J., 1998b, Slope maps of the San Francisco Bay Region, CA: U.S. Geol. Survey, Open-file Report 98-766, 17 p.; http://wrgis.wr.usgs.gov/open-file/of98-766/. [data \& printer plots computed fr ca. $24 \mathrm{M}$ elevs spaced at $30 \mathrm{~m}$ ]

Graham, S.T., Famiglietti, J.S., and Maidment, D.R., 1999, Five-minute, $1 / 2^{\circ}$, and $1^{\circ}$ data sets of continental watersheds and river networks for use in regional and global hydrologic and climate modeling studies: Water Resources Research, v. 35, no. 2, p. 583-587. [ult. DEM-to-watershed; fr. TerrainBase 5' Global DTM \& CIA World Data Bank II]

Graniero, P.A., and Price, J.S., 1999, The importance of topographic factors on the distribution of bog and heath in a Newfoundland blanket bog complex: Catena, v. 36, no. 3, p. 233-254. [DEM params.-esp. substrate area, slope \& plan curv-explain $22 \%$ variance]

Granö, J.G., 1929, Relative height classification, in Reine Geographie: Acta Geographica, v. 2, no. 2 (202 p.), p. 70-72. [0-5m flat, 5-10m hillocks, 10-20m etc.; 1st Finnish quant. work?] 
Grayman, W.M., Males, R.M., Gates, W.E., and Hadder, A.W., 1975, Land-based modeling system for water quality management studies: Journal of the Hydraulics Division, ASCE, v. 101, p. 567580. [TIN system, ADAPT, developed independently of Peucker's concept]

Grayson, R.B., and Blöschl, Günter, 2000, Spatial modelling of catchment dynamics, Chap. 3, in Grayson, R.B., and Blöschl, Günter, eds., Spatial Patterns in Catchment Hydrology: Cambridge (UK) Univ. Press, p. 51-81. [pp. 56-70 good on model structure, discretisation, element size \& linkage]

Grayson, R.B., Moore, I.D., and McMahon, T.A., 1992, Physically based hydrologic modelling, I. A terrain-based model for investigative purposes: Water Resources Research, v. 28, no. 10, p. 26392659. [parses terrain by steepest upslope lines search; yields better ridges than channels]

Green, J.F.N., Bull, A.J., Gossling, F., Hayward, H.A., Turner, E.A., and Wooldridge, 1934, The river Mole-its physiography and superficial deposits: Proceedings of the Geologists' Association, v. 45, part 1, p. 35-69. [measured long. profiles of trunk \& tributaries; fit eqn. to upstream data \& terraces to est. former profile]

Griffin, M., Beasley, D., Fletcher, J., and Foster, G., 1988, Estimating soil loss on topographically nonuniform field and farm units: Journal of Soil and Water Conservation, July/August, p. 326-331. [making slope-length calc. biggest problem in applying USLE]

Gritzner, M.L., Marcus, W.A, Aspinall, Richard, and Custer, S.G., 2001, Assessing landslide potential using GIS, soil wetness modeling and topographic attributes, Payette River, Idaho: Geomorphology, v. 37, nos. 1-2, p. 149-165. [Bayes model; small slides; slope \& elev. best predictors; aspect, plan \& profile curv., upslope A, flowpath L, moisture index not significant]

Grout, B.W., Jr., 1994, A history of digital elevation model production at RMMC: Rocky Mountain Benchmark (USGS Rocky Mountain Mapping Center, Denver Federal Center, CO), v. 3, no. 3, paging unknown. [incl. description of manual profiling technique that generated striped artifacts in early (Level 1) USGS DEMs]

Günther, S., 1875, Die Küstenentwicklung, ein mathematischer Beitrag zur vergleichenden Erdkunde (coastal convolution, a mathematical contribution to comparative geography, in German): Grunerts Archiv der Math. und Physik, v. 57, p. 277-284. [the area/perimeter relation; quoted by Rohrbach, 1890]

Günther, S., 1882, Die wahre Definition des Begriffes 'Küstenentwicklung' (the true definition of the term 'coastal convolution', in German): Verh. d. II, Deutschen Geograpentages zu Halle, p. 141146, plus comments on the lecture by Keber, Zöppritz, \& Breusing on p. 146. [the area/perimeter relation; see review by Rohrbach, 1890]

Gupta, V.K., and Mesa, O.J., 1988, Runoff generation and hydrologic response via channel network geomorphology - recent progress and open problems: Journal of Hydrology, v. 102, no. 1-4, p. 328. [must add terrain height to planimetric network models]

Guráu, Lidia, 2000, The Correlation of Sanded Wood Surface Roughness to Wood Structure and Finish Quality: Dept. of Forest Products Technology, Buckinghamshire Chilterns University College, UK, Ph.D. thesis; for research proposal, see http://www.bcuc.ac.uk/technology/FPRC/TRAINING/LidiaGurau.htm. ["to improve understanding of how process variables influence surface roughness of sanded solid wood"; excellent intro \& biblio on morphometry of finished wood]

Gustafson, E.J., 1998, Quantifying landscape spatial pattern-what is the state of the art?: Ecosystems, v. 1, p. 143-156. [indices, spatial heterogeneity, patchiness, scale, geostatistics, autocovariation, spatial models] 
Gustafson, E.J., Murphy, N.L., and Crow, T.R., 2001, Using a GIS model to assess terrestrial salamander response to alternative forest management plans: Journal of Environmental Management, v. 63, p 281-292. [position on slope between ridge crest and valley bottom fr $30 \mathrm{~m}$ DEM]

Guth, P.L., 1999a, Quantifying topographic fabric-eigenvector analysis using digital elevation models, in Merisko, R.J., ed., Advances in Computer-Assisted Recognition: Applied Imagery Pattern Recognition (AIPR) Workshop, 27th, Washington DC, 14-16 October 1998, Proceedings: SPIE (Intl. Soc. Optical Engrg.) v. 3584, p. 233-243. [adapts Woodcock's 1977 eigenvector method; $\ln (\mathrm{S} 1 / \mathrm{S} 2)$ or 'flatness' \& In(S2/S3) or 'organization' to DEMs]

Guth, P.L., 1999b, Quantifying and visualizing terrain fabric from digital elevation models, in Diaz, J., Tynes, R., Caldwell, D., and Ehlen, J., eds., International Conference on GeoComputation, 4th, Fredericksburg VA, Mary Washington College, 25-28 July, GeoComputation 99: CD-ROM ISBN 09533477-1-0; http://www.geovista.psu.edu/geocomp/geocomp99/Gc99/096/gc_096.htm. [DEMbased classific. on elev., 'ruggedness', \& topo fabric (fr. eigen-analysis)]

Guth, P.L., 1999c, Contour line 'ghosts' in USGS Level 2 DEMs: Photogrammetric Engineering and Remote Sensing, v. 65, no. 3, p. 289-296. [3 ways to show bias in contour-to-grid comp.; Lev. 2 still better than Lev. 1]

Guth, P.L., 2001, Quantifying terrain fabric in digital elevation models, in Ehlen, Judy, and Harmon, R.S., eds., The environmental legacy of military operations: Geological Society of America Reviews in Engineering Geology, v. 14, p. 13-25. [continues work on terrain fabrics in two 1999 papers to automate the SSO diagram of Chapman 1951 \& 52]

Guzzetti, Fausto, Malamud, B.D., Turcotte, D.L., and Reichenbach, Paola, 2000, Power-law correlations of Italian landslide areas (abs.): Eos Transactions of the American Geophysical Union, v. 81, no. 48 (Supplement, NG62C-19), p. F566. [area/freq. scaling statistics independent of trigger mech.]

Gvin, V.Ya., 1963, Application of morphometry in structural studies of the Upper and Middle Volga and Kama Regions (in Russian), in Problems of Geography, no. 63, Quantitative Methods in Geomorphology: Geographizdat, Moscow, p. 64-80. [no info]

Gwinner, Klaus, Hauber, Ernst, Jaumann, Ralf, and Neukum, Gerhard, 2000, High-resolution, digital photogrammetric mapping - a tool for Earth science: Eos, Transactions, American Geophysical Union, v. 81 , no. 44, p. $513,516, \& 520$. [state-of-art technique to get DEMs \& ortho-images]

Haas, C., Liu, Q., and Martin, T., 1999, Retrieval of Antarctic sea-ice pressure ridge frequencies from ERS SAR imagery by means of in situ laser profiling and usage of a neural network: International Journal of Remote Sensing, v. 20, no. 15 \& 16, p. 3111-3123. [large area; 30\% error; Fisher-K stats + half width \& tail-to-mean ratio]

Hack, J.T., 1965, Geomorphology of the Shenandoah Valley Virginia and West Virginia and origin of the residual ore deposits: U.S. Geological Survey Professional Paper 484, 84 p. [map of relief / sq. mi.; hypso. curves; quant. slope-profile analysis; long. stream profiles; azimuthal asymmetry of slope]

Hack, J.T., and Goodlett, J.C., 1960, Geomorphology and forest ecology of a mountain region in the Central Appalachians: U.S. Geological Survey Professional Paper 347, 66 p. [early postwar USGS quant.; var. relations, long. profile, slope asymmetry, etc.; recaps G.K. Gilbert concepts; 1st? assoc. of concave-straight-convex slopes w/ var. in vegetation \& moisture content] 
Hadley, R.F., 1961, Some effects of microclimate on slope morphology and drainage basin development, in Geological Survey research 1961, short papers in the geologic and hydrologic sciences, articles 1-146: U.S. Geological Survey Professional Paper 424-B, art. 16, p. 32-34. [Slope/aspect rose diagram $(n=50)$; rekated to drainage density \& veg.]

Hagen, J.O., Etzelmüller, Bernd, and Nuttall, A.-M., 2000, Runoff and drainage pattern derived from digital elevation models, Finsterwalderbreen, Svalbard: Annals of Glaciology, v. 31, p. 147-152. [surging glacier; difference 1970 \& 1990 DEMs; flowpaths fr DEM]

Hagood, M.J., 1943, Statistical methods for delineation of regions applied to data on agriculture and population: Social Forces, , v. 21, p. 287-297. [early use of principal-components analysis in regional classification]

Hann, R.A., 1957, A method of quantitative topographic analysis of wood surfaces: Forest Products Journal, v. 7, no. 12, p. 448-452. [need for roughness QC for machined wood surfaces \& conformance to prescribed standards, as on metals]

Hall, D.B., 1998, Using digital elevation models to calculate a time-averaged landscape denudation rate: Physical Geography, v. 19, no. 4, p. 341-349. [subtr. pre- fr. post-erosion surface to get basin vol. (age interval known]

Halsey, T.C., 2000, Diffusion-limited aggregation-a model for pattern formation: Physics Today, v. 53 , no. 11, p. 36-41. [topologic scaling of rivers = one example; shows importance of geomorph. processes in the physical sciences]

Hamilton, G.S., and Dowdeswell, J.A., 1996, Controls on glacier surging in Svalbard: Journal of Glaciology, v. 42 , no. 140 , p. 157-168. [univariate analysis of 615 glac.: signif. diff. geom.; $L$ is dominant]

Hancock, G.R., and Willgoose, G.R., 2001, The production of digital elevation models for experimental model landscapes: Earth Surface Processes and Landforms, v. 26, no. 5, p. 475-490. [slope/A plots fr $6.0 \mathrm{~mm} \pm 2.0 \mathrm{~mm}$-grid DEM of mini-terrain]

Hancock, G.R., and Willgoose, G.R., 2001, Use of a landscape simulator in the validation of the SIBERIA catchment evolution model-declining equilibrium landforms: Water Resources Research, v. 37, no. 7, p. 1981-1992. [model OK, but DEM error critical to derived statistics]

Hankley, Chip, 1999, Quaternary landforms in Wisconsin-how hillshading can be used to accentuate topographic features, in Soller, D.R., ed., Digital Mapping Techniques '99, Workshop Proceedings: U.S. Geological Survey Open-File Report 99-386, p. 205-209, http://pubs.usgs.gov/of/of99-386/hankley.html. [adapts Haugerud/Greenberg color Arc/lnfo AML algorithm to WI 30m DEM]

Hansen, M.F., 1984, Strategies for classification of landslides, chap. 1 in Brunsden, Denys, and Prior, D.B., eds., Slope Instability: London, Wiley, p. 1-25. [reviews morphometric approaches of Skempton 1953, Brunsden 1973, Blong 1973, Crozier 1973]

Hanssen, R.F., 2001, Radar Interferometry-data interpretation and error analysis: Dordrecht/Boston/London, Kluwer, 308 p. [useful historical background \& review]

Hardy, R.J., Bamber, J.L., and Orford, S., 2000, The delineation of drainage basins on the Greenland ice sheet for mass-balance analyses using a combined modelling and geographical information system approach: Hydrological Processes, v. 14, nos. 11-12, p. 1931-1941. [10 'ice basins' by Arc/Info GIS from 2.5-km DEM (ERS-1 data) \& 'balance flux'] 
Harrison, A.R., and Dunn, R., 1993, Problems of sampling the landscape, in Haines-Young, R.H., Green, D.R., and Cousins, S.H., eds., Landscape Ecology and Geographic Information Systems: London, Taylor and Francis, p. 101-109. [spatial sampling must accommodate 2D \& 3D variables]

Harrison, K., and Thackeray, A.D., 1940, On the direction of certain valleys: Geological Magazine, v. 77 , no. 2 , p. $82-88$. [azimuth-freq. diagrams $(25-\mathrm{ft}$ river segments; $150<\mathrm{n}<1110)$ related to joints, not glaciation]

Hartshorne, James, 1997, Assessing the influence of digital terrain model characteristics on tropics slope stability analysis, in Kemp, Z.A., ed., Innovations in GIS 4: London, Taylor and Francis, p. 198-214. [DEM resolution \& quality significantly affect hazard-zonation models]

Haruyama, M., and Kitamura, R., 1984, An evaluation method by the quantification theory for the risk degree of landslides caused by rainfall in active volcanic area, in International Symposium on Landslides, 4th, 16-21 September, Toronto, Proceedings: Rexdale, Ont., Canadian Geotechnical Society, v. 2, p. 435-440. [Eigenvector analysis of elev., contour \& stream density, rel. relief, slope form, geology, \& land use]

Harvey, C.A., and Eash, D.A., 1996, Description, instructions, and verification for BASINSOFT, a computer program to quantify drainage-basin characteristics: U.S. Geological Survey, WaterResources Investigations Report 95-4287, 25 p. [27 morphometric parameters fr Arc/Info AML macro compare well $w /$ manually derived measures]

Hasbargen, L.E., and Paola, Chris, 2000, Landscape instability in an experimental drainage basin: Geology, v. 28, no. 12, p. 1067-1070. [lab analog model $1 \mathrm{~m}$ across; ridge density @ $1 \mathrm{~cm}^{2}$ resolution]

Hassan, M.M., 1988, Filtering digital profile observations: Photogrammetric Engineering and Remote Sensing, v. 54, no. 10, p. 1391-1394. [low-pass filtering of white noise to reduce error in level-1 USGS DEMs]

Haxby, W.F., 1985, Gravity field of world's ocean (color map): Boulder, CO, National Geophysical Data Center, NOAA, Reporty MGG-3. [Seasat radar altimetry; important precursor to Smith \& Sandwell 1997 map \& DEM]

Hayakawa, N., et al. (no author info), 1995, Study on extracting drainage network from square-grid DEM (in Japanese): Annual Journal of Hydraulic Engineering, JSCE, v. 39, p. 127-132. [pits in DEM \& flat areas pose big problems]

Hayashi, M., and van der Kamp, G., 2000, Simple equations to represent the volume-area-depth relations of shallow wetlands in small topographic depressions: Journal of Hydrology, v. 237, nos. $1-2$, p. 74-85. [also profiles \& \% hypsometric curves]

Hayes, Brian, 2000, Dividing the continent: American Scientist, v. 88, no. 6, p. 481-481. [computer scientist discovers terrain-watersheds, divides, Cayley \& Maxwell, DEMs, \& image analysis]

Haynes, V.M., 1968, The influence of glacial erosion and rock structure on corries in Scotland:

Geografiska Annaler, v. 50A, no. 4, p. 221-234. [curves $y=$ of form $k(1-x) e^{-x}$ better fit longitudinal profiles of cirques than circles]

Head, J.W. III, Hiesinger, Harald, Ivanov, Mikhail, Kreslavsky, M.A., Pratt, Stephen, and Thomson, B.J., 1999, Possible ancient oceans on Mars-evidence from Mars Orbiter Laser Altimeter data: Science, v. 286, no. 5447, p. 2134-2137. [elev \& slope maps, relief shading, flooding-vol. est.]

Head, J.W. III, Kreslavsky, Mikhail, Hiesinger, Harald, Ivanov, Mikhail, Pratt, Stephen, and Seibert, Nicole, 1998, Oceans in the past history of Mars-test for their presence using Mars Orbiter Laser 
Altimeter (MOLA) data: Geophysical Research Letters, v. 25, no. 24, p. 4401-4404. [Elev. \& slope; poss. shoreline @ lowland plains; slope/scale-length relation]

Head, J.W. III, Yuter, S.E., and Solomon, S.C., 1981, Topography of Venus and Earth-a test for the presence of plate tectonics: American Scientist, v. 69, no. 6, p. 614-623. [topo profiles \& whole-planet \% hypso. curves for both; Venus elevs (Pioneer altimetry) not bimodal]

Heikkinen, Olavi, 1975, A trend-surface analysis of relief in Sipoo, southern Finland: Fennia, v. 141, p. 1-54. [valley, mean, \& summit heights fr. $1 / 20 \mathrm{~K} \& 50 \mathrm{~K}$ topo maps]

Hemenway, D.D., 1995, An efficient analytical approach for generating digital elevation models: Alberta, University of Edmonton, M.Sc. thesis, paging unknown. [DEM fr digitized random elevs by a multiquadric technique, QSURF]

Henkel, L., 1900, Berechnung der Dichte des Eisenbahnnetzes (calc. density of railroad networks; in German): Geographische Zeitschrift, v. 6, p. 220-221. [adapted to drainage density; $x=2 A / L ; P$ = unit-cell area $\& L=$ total length]

Hennrich, Kirsten, Schmidt, Jochen, and Dikau, Richard, 1999, Regionalization of geomorphometric parameters in hydrological modelling using GIS, in Diekkrüger, Bernd, Kirkby, M.J., and Schröder, Ulrich, eds., Regionalization in Hydrology: Conference, Technical University of Braunschweig, Germany, 10-14 March, 1997, Proceedings: IAHS Publication no. 254, p. 181-191. [morph params correl. $w /$ hydro indices is scale dependent $\&$ better at fine scales]

Herrick, R.R., and Lyons, S.N., 1998, Inversion of crater morphometric data to gain insight on the cratering process: Meteoritics and Planetary Science, v. 33, p. 131-143. [complex crater d, d/D threshold, onset $D$ for peaks, terraces, \& peak rings.; acoustic fluidization model (Melosh 1982) \& nonproportional growth (Schultz 1988) in published forms do not reproduce morph. data. Most data consistent $\mathrm{w} /$ linear dependence on crustal strength / hydrostatic pressure, c/rg.]

Herrick, R.R., and Sharpton, V.L., 2000, Implications from stereo-derived topography of Venusian impact craters: Journal of Geophysical Research, v. 105/E8, p. 20,245-20,262. [Venusian craters $50 \%$ deeper than complex craters on Earth; other quant. results]

Herzfeld, U.C., and Overbeck, Christoph, 1999, Analysis and simulation of scale-dependent fractal surfaces with application to seafloor morphology: Computers and Geosciences, v. 25, no. 9, p. 979-1007. [methods capture roughness \& anisotropy, \& extrapolate to other scales \& locations]

Herzfeld, U.C., Kim, I.I., Ocutt, J.A., and Fox, C.G., 1993, Fractal geometry and seafloor topography - theoretical versus data analysis for the Juan de Fuca Ridge and the East Pacific Rise: Annales Geophysicae, v. 11, no. 6, p. 532-541. [seafloor fractal, but neither self-similar, self-affine, nor multifractal in usual sense]

Hevelius, Johannes, 1647, Selenographia, sive Lunae descriptio, atque accurata tam macularum ejus, quam motuum diversorum, aliarumque omnium vicissitudinum phasiumque telescopi ope deprehensarum, delineatio. Addita est nova ratio lentes expoliendi, telescopia construendi, et horum adminiculo varias observationes exquisite instituendi (in Latin): Danzig, Hünefeld for the author, 563 p. +111 engravings. [1st good atlas of Moon, not surpassed for 100 yrs.; a few relative-height determinations from shadow lengths were later compared by Schröter (1791) with his]

Hickey, R.J., 2000, Slope angle and slope length solutions for GIS: Cartography (Canberra), v. 29, no. 1, p. 1-8. [updates 1994 Hickey et al. computations for USLE]

Hill, J.M., Graham, L.A., and Henry, R.A., 2000, Wide-area topographic mapping and applications using airborne Llght Detection and Ranging (LIDAR) technology: Photogrammetric Engineering 
and Remote Sensing, v. 66, no. 8, p. 908-909, 911-914, $927 . \quad$ [nontechnical intro./review; good biblio]

Hilley, George, and Arrowsmith, Ramon, 2001, Santa Cruz Mountains and San Francisco Bay Peninsula Morphometry: http://activetectonics.la.asu.edu/scm/morphometry/morphometry.html. [envelope, sub-envelope, \& elev. residuals maps fr $1 / 24 \mathrm{~K}$ DEMs by Arc/Info macro]

Herdt, K.N., Rodhe, Allan, Seibert, Jan, and McDonnell, J.J., 1998, Testing DTM-based spatial soil moisture predictions with peat mapping in forested central Sweden (abs.), Transactions of the American Geophysical Union, v. 79, no. 45, supplement, p. F249. [new 'drainage efficiency index' outperformed TOPMODEL by $20 \%]$

Hochstöger, F., 1995, Verwaltung landesweiter Geländehöhendaten (in German; Administration of country-wide land-height data): Salzburger Geographische Materialien, no. 22, p. 98-106; http://www.ipf.tuwien.ac.at/veroeffentlichungen/fh_p_agit95.html\#ZF. [managing the Austrian 250-m DEM; oblique relief-shaded image]

Hodgson, M.E., and Gaile, G.L., 1996, Characteristic mean and dispersion in surface orientations for a zone: International Journal of Geographical Information Systems, v. 10, no. 7, p. 817-830. [circ. stats.]

Hodgson, M.E., and Gaile, G.L., 1999, A cartographic modeling approach for surface orientationrelated applications: Photogrammetric Engineering and Remote Sensing, v. 65, no. 1, p. 85-95. [bi-directional angles in DEMs as Hemisph. vectors using linear algebra]

Hoffmann, Klaus, Fleck, W., Gündra, H.I., and Dikau, Richard, 1993, Computergestützte Modellierungen zu Relief-Bodenbeziehungen in Lößgebieten Nord-Baden-Württembergs (computer-aided modelling to resolve relief-soil relations in no. Bavaria \& Wurtt.): Mitteilungen der Deutschen Bodenkundlichen Gesellschaft, v. 72, p. 935-938. [10 params.: slope; aspect; plan \& prof. curv.; up- \& downslope flowlengths, height diffs.; upslope area \& slope]

Holmes, K.W., 1999, Calculation of error in a USGS 30-meter digital elevation model and its effects on terrain attributes and environmental modeling: Santa Barbara, University of California, M.A. thesis, 91 p. [see Holmes et al. 2000]

Holmes, K.W., Chadwick, O.A., and Kyriakidis, P.C., 2000, Error in a USGS 30-meter digital elevation model and its impact on terrain modeling: Journal of Hydrology, v. 233, nos.1-4, p. 154-173. [used GPS data; several params. eval.; geostat. modeling; propagation error worst in drains \& along streamlines]

Hook, J.C., 1954, The quantification of Landform Characteristics: lowa City, State University of lowa, mimeographed, unpublished, 17 p. [discusses 18th German \& later morphometry (fr Neuenschwander 1944); seminar paper and/or part of 1955 thesis?]

Hooke, R.LeB., 1968, Steady-state relationships on arid-region alluvial fans in closed basins: American Journal of Science, v. 226, no. 8, p. 609-629. [log-log fan/basin area; basin slope/area; fan slope/basin area]

Hooke, R.LeB., 2000, Toward a uniform theory of clastic sediment yield in fluvial systems: Geological Society of America Bulletin, v. 112, no. 12, p. 1778-1786. [elev., relief, slope angle \& length]

Horton, R.E., 1941, Sheet erosion-present and past: Transactions, American Geophysical Union, v. 22, pt. 2, p. 299-305. [measured large river-basins are 'pear-shaped ovoids' in plan, as are basins modeled fr parabolic cross \& long. sections]

Hoss, H., 1996, DTM Derivation with laser scanner data: Geomatics Information Magazine, v. 10 , no, 10 , p. 28-31. [addresses caveats \& quality control as well as flow of procedural steps] 
Hoss, H., 1997, Einsatz des Laserscanner-Verfahrens beim Aufbau des digitalen

Geländehöhenmodells DGM in Baden-Württemberg (in German): Photogrammetrie Fernerkundung Geoinformation, v. 2, p. 131-142. [a procedure for DEM generation from laser-scanned heights]

Houbolt, J.C., Walls, J.H., and Smiley, R.F., 1955, On spectral analysis of runway roughness and lads developed during taxiing: Washington, D.C., NACA Technical Note 3484, 9 p. [summarizes PSD material, e.g. Walls et al. 1954]

Hovius, Niels, 1996, Regular spacing of drainage outlets from linear mountain belts: Basin Research, v. 8 , no. 1, p. 29-44. [important neo-orometry! char. stream spacing ( $n=205,1 / 250 \mathrm{~K}-1 / 1000 \mathrm{~K}$ topo maps) for 10 orogens $=2.07 \pm 0.16$ the half-width of the mtn. belt (median= 2.13 ); Himalayas the exception (spacing ratio=1.17); no explanation; related to Hack's law?]

Howard, Alan D., 1989, Morphometry of planimetric landforms: Reports of Planetary Geology and Geophysics Program - 1988: NASA Technical Memorandum 4130, p. 313-315. ['path-cutting' \& 'convex-stepping' metrics for scarps \& fluvial systems]

Howarth, P.J., and Bones, J.G., 1972, Relationships between geometric form and process on high Arctic debris-slopes, southwest Devon Island, Canada, in Price, R.J., and Sugden, D.E., eds., Polar Geomorphology: Institute of British Geographers, Special Publication 5, p. 139-153. [measured profiles of talus slopes]

Hrnciarová, Tatiana, and Miklós, Ladislav, 1991, Morphometric indices in the interpretation of water and material motion dynamics illustrated on the example Dolná Malanta: Ecology (CSFR), v. 10, no. 2, p. 187-221. [no info]

Hsia, J.-S., and Newton, lan, 1999, A method for the automated production of digital terrain models using a combination of feature points, grid points, and filling back points: Photogrammetric Engineering and Remote Sensing, v. 65, no. 6, p. 713-719. [digital photogrammetry]

Hsu, M.-L., and Robinson, A.H., 1970, The fidelity of isopleth maps, an experimental study: Minneapolis, University of Minnesota Press, $92 \mathrm{p}$. [depends on character of source distribution (i.e. topo), size \& shape of mapping units (pixels), \& the number of control points]

Huang, C., 1998, Quantification of soil microtopography and surface roughness, in Baveye, Phillipe, Stewart, B.A., and Parlange, J.-Y., eds., Fractals in Soil Science: Berlin, Springer Verlag, p. 153168. [used 2-D laser scanner to make DEM]

Huang, Y.D., 2000, Evaluation of information loss in digital elevation models with digital photogrammetric systems: Photogrammetric Record, v. 16, no. 95, p. 781-791. [uses rms differences betw. candidate DEM \& a much denser DEM 'standard']

Hubbard, Bryn, Siegert, M.J., and McCarroll, Danny, 2000, Spectral roughness of glaciated bedrock geomorphic surfaces-implications for glacier sliding: Journal of Geophysical Research, v. 105, no. B9, p. 21,295-21,303. [micro- \& macro-profiles combine in 5-order PSD's that yield 2 bedroughness indices]

Huber, William, 1825, Considérations générales sur les Alpes centrales (in French): Bulletin de la Société Géographique de Paris, v. 5, p. 105ff. [refined Humboldt's quant. comparison of ridge \& summit mean heights by averaging all summits rather than just a sampling]

Huggett, R.J., 1975, Soil landscape systems-a model of soil genesis: Geoderma, v. 13, no. 1, p. 122. [added flow lines to Troeh's 1964 four concave-convex elements to segment land-surface form by slope \& curvature; 4 block diagrams; crude computer result] 
Huggins, K.H., 1935, The Scottish Highlands-a regional study: Scottish Geographical Magazine, v. 51 , p. 296-306. [delimited by relief $\left(>700^{\prime}\right)$ on 2-mi. grid (O.S. maps); used $800^{\prime}$ contour \& summits $\left.>1500^{\prime}\right]$

Huggins, L.F., and Monke, E.J., 1966, The mathematical solution of the hydrology of small watersheds: Purdue University, W. Lafayette, IN, Water Resources Research Center, Technical Report No. 1, 130 p. [one of 1st true distributed-parameter hydrologic models; basis of ANSWERS model]

Hughes, D.A., 1981, An approach to the quantification of floodplain form: Area (London), v. 13, no. 4, p. 285-291. [no info]

Hughes, L.A., Smith, D.H., and Ryley, A., 2001, Robust data compression for digital elevation models (ext. abs.), in Kidner, D.B., and Higgs, G., eds., GIS Research UK 9th, Annual Conference (GISRUK 2001), University of Glamorgan, Wales, 18-20 April 2001, Proceedings: p. 462-467. [no info]

Hughes, R.J., Jr., 1959, Volume estimates from contours: Economic Geology, v. 54, no. 4, p. 730737. [exemplified by cut-and-fill grading of an area]

Humâ, lo., and Râdulescu, D., 1978, Automatic production of thematic maps of slope stability: Bulletin of the International Association of Engineering Geology, no. 17, p. 95-99. [early computer map fr quant. coding of variables incl. slope \& aspect]

Humboldt, Alexander von, 1808, et ann. suiv., Nivellement barométrique fait dans les régions équinoxiales du Nouveau Continent 1799-1804 (in French; barometric surveying in equatorial regions of the Americas), published as a separate from Recueil d'observations astronomiques, d'opérations trigonométriques et de mesures barométriques, Partie 4, 2 vol. (v. 21 \& 22) Paris, F. Schoell, Treuttel \& Würtz, in Alexandre de Humboldt et Aimé Bonpland, 1805-34, Voyage aux régions équinoxiales du nouveau continent fait en 1799, 1800, 1801, 1802, 1803 et 1804, $30 \mathrm{v}$., paging unknown. [500 heights calculated by Jabbo Oltmanns fr Humboldt's measurements, Laplace's formula, \& Ramond's barometric coeff. It may have been here (otherwise in an unspecified 1807 work) where Humboldt complained that heights of only 62 of the world's mountains were measured and he had accounted for half]

Humboldt, Alexander von, 1817, De distributione geographica plantarum secundum coeli temperiem et altitudinem montium, Prolegomena (in Latin; on the geogr. distr. of plants in the new world, temperatures, \& heights of mountains): Lutetiae Parisiorum, Paris \& Lubeck, 250 p., hand-colored engraved foldout map. [footnote to p. 112 in Edinb. New Phil. Jour., (1845, v. 39) says p. 81 \& 182 (82?) of the 1817 work mention 'the distinction which is so important to climatology \& human civilization, of continents having uniform, and those having indented coasts; .... the relation of the extent of coasts to the area of the continent, which is ... the measure of the accessibility of the interior' This is the (later) much-pursued quantification of continental area/perimeter, or 'coastal development' (Küstenentwicklungen i.e. 'convolution'). The concept, attributed by Humboldt to Strabo \& evidently 1 st quantified by Ritter $(1826,1828)$, claims that highly indented coasts, e.g. Europe, lead to more advanced cultures]

Humboldt, Alexander von, 1835, article title unknown: Berghaus' Annalen der Erdkunde, v. 12, p. 490ff. [contains material on '... the relation of the extent of coasts to the area of the continent, which is ... the measure of the accessibility of the interior ...' (ref. = Edinb. New Phil. Jour., 1845, v. 39, p. 112 footnote is early mention in English of the (later) much-pursued quantification of continental area/perimeter, or 'coastal development' (i.e. Küstenentwicklungen or 'convolution'). The concept, attributed by Humboldt to Strabo \& evidently 1st quantified by Ritter $(1826,1828)$, claims that highly indented coasts, e.g. Europe, lead to more advanced cultures]

Humboldt, Alexander von, 1843c, An attempt to determine the height of continents: Edinburgh New Philosophical Journal, v. 34, art. 12, p. 326-337. [measured heights refute Laplace's 1825 
deduced mean height of Earth's continents of $1000 \mathrm{~m} \mathrm{(3028)}$ ); see several other A. von H. refs. to this work]

Hunt, C.B., 1950, Military geology, in Paige, Sidney, ed., Application of Geology to Engineering Practice: Geological Society of America, p. 295-327. ['scopograph' instrument projected contour maps into landing-craft-level visualizations of terrain; basic descr. of terrain (incl. map units) for observation, concealment, cover, trafficability; WW II experience]

Hurtrez, J.-E., Lucazeau, F., Lavé, J., and Avouac, J.-P., 1999, Investigation of the relationships between basin morphology, tectonic uplift, and denudation from the study of an active fold belt in the Siwalik Hills, Nepal: Journal of Geophysical Research, v. 104, no. B6, p. 12,779-12,796. [of 27 params (17 basins), only basin elev \& hyps. int. correl signif. w/ uplift rate; re-derives hypsometric integral (no ref. to Pike \& Wilson 1971)]

Hutchinson, M.F., 2001, ANUDEM version 4.6.3: Canberra, Centre for Resources and Environmental Studies, Australian National University; http://cres.anu.edu.au/outputs/anudem.html. [successful software package; yields accurate DEMs with sensible drainage properties $\mathrm{fr} \sim$ small, but well chosen, elev. \& stream line data]

Hutchinson, M.F., and Gallant, J.C., 1999, Representation of terrain, ch. 9, in Longley, P.A., Goodchild, M.F., Maguire, D.J., and Rhind, D.W., eds., Geographical Information Systems, v. 1, Principles and Technical Issues, 2nd ed.: New York, Wiley, p. 105-124. [state-of-art review of DEMs \& modeling, supplants Weibel \& Heller, 1991]

Hutchinson, M.F., and Gallant, J.C., 2000, Digital elevation models and representation of terrain shape, in Wilson, J.P., and Gallant, J.C., eds, Terrain Analysis-Principles and Applications: New York, Wiley, p. 29-50. [review, emphasizing ANUDEM software package]

Hutchinson, M.F., Stein, J.L., and Stein, J.A., 2001, Upgrade of the 9 second Australian digital elevation model-A joint project of CRES and AUSLIG: CRES, ANU, http://cres.anu.edu.au/dem/index.html. [intro, sample images, purchase, GEODATA 9" DEM hist \& descr, revised source data, ANUDEM gridding algorithm, accuracy est., refs]

Ibbit, R.P., Willgoose, G.R., and Duncan, M.J., 1999, Channel network simulation models compared with data from the Ashley River, New Zealand: Water Resources Research, v. 35, no. 12, p. 38753890. [250-m DEM; OCN \& SIBERIA tested-neither satisfactory; used hypso. int.]

Ijjasz-Vasquez, E.J., Rodriguez-Iturbe, Ignacio, and Bras, R.L., 1992, On the multifractal characterization of river basins: Geomorphology, vol. 5, nos. 3-5, p. 297-310. [develops multifractal spectra of various parameters]

Inamdar. S.P., and Dillaha, T.A., 2000, Relationships between drainage area, slope length, and slope gradient for riparian slopes in Virginia: Transactions of the American Society of Agricultural Engineers, v. 43, no. 4, p. 861-866. [contributing areas computed fr 1-m DEMs; infer fine-scale A fr coarser-scale params.]

Inbar, M., and Risso, C., 2001, A morphological and morphometric analysis of a high density cinder cone volcanic field-Payun Matri, south-central Andes, Argentina : Zeitschrift fur Geomorphologie, v. 45 , no. 3 , p. 321-343. [summ. 120 cones \& 8 groups; params. Hco, Wco, ratio, slope, Dcr]

Inkpen, R.J., Collier, Peter, and Fontana, Dominic, 2000, Close-range photogrammetric analysis of rock surfaces: Zeitschrift für Geomorphologie, Supplementband 120, p. 67-81. [DEMs \& variograms of weathered vs. unweathered surfaces] 
Iri, M., Shimakawa, Y., and Nagai, T., 2000, Extraction of invariants from digital elevation data with applications to terrain topography (in Japanese): Symposium on Integrated Geographical Information Systems, Proceedings: v. 5, p. 33-46. [peaks, bottoms (pits), \& cols (passes) = critical points]

Ivanov, S.S., 1994, Global relief-evidence of fractal geometry, in Kruhl, J.H., ed., Fractals and Dynamic Systems in Geoscience: Berlin, Springer-Verlag, p. 221-230. [1975 revised Scripps topo data on $1^{\circ}$ global grid; gets $D=1.37$ ]

Ivanov, M.A., and Head, J.W., 2001, Altitude distribution of units, §3.4 in Geology of Venus-mapping of a global geotraverse at $30^{\circ} \mathrm{N}$ latitude: Journal of Geophysical Research, v. 106 , no. E8, p. 17,544-17,546. [hypsograms suggest 3 groups of geologic units]

Iwahashi, Junko, and Kamiya, Izumi, 1995, Landform classification using digital elevation model by the skills of image processing - mainly using the Digital National Land Information: Joho Chishitsu (Geoinformatics; Osaka), v. 6, no. 2, p. 97-108. [no info; probably related to Iwahashi 1994?]

Iwahashi, Junko, Watanabe, Shiaki, and Furuya, Takahiko, 2001, Landform analysis of slope movements using DEM in Higashikubiki area, Japan: Computers \& Geosciences, v. 27, no. 7, p. 851-865. [spatial freq. $\approx$ failure proclivity; slope dist. normal on slides, but not stable terrain]

\section{$\mathbf{J}$}

Jackson, C.R., and Sturm, C.A., 2002, Woody debris and channel morphology in first- and secondorder forested channels in Washington's coastal ranges: Water Resources Research, v. 38, no. 9, p. 16-1 to 16-14. [step-pool freq., step height / channel slope; streams probl. 'step-riffle' not 'steppool']

Jäger, Stefan, 1993, Computergestützte Erzeugung und Anwendung umweltrelevanter Basisdaten der Reliefgeometrie (Computer-assisted production and use of environmentally relevant basic data of relief geometry), in Barsch, Dietrich, and Karrasch, Heinz, eds. Geographie und Umwelt: Tagungsbericht und wissenschaftl. Abhandlungen, 48, Deutscher Geographentag 1991, Wiesbaden, Steiner Verlag, p. 153-158. [no info]

Jäger, Stefan, and Wieczorek, G.F., 1994, Landslide susceptibility in the Tully Valley area, Finger Lakes region, New York: U.S. Geological Survey, Open-file report 94-615, one sheet, 1/50,000 scale. [fr. logistic regr. of 90-m DEM slope, old lake levels \& pres./abs. of clays]

Jakobsson, Martin, Cherkis, Norman, Woodward, John, Macnab, Ron, and Coakley, Bernard, 2000, New grid of Arctic bathymetry aids scientists and mapmakers: Eos, Transactions, American Geophysical Union, v. 81, no. 9, p. 89, 93, \& 96;

http://www.ngdc.noaa.gov/mgg/bathymetry/arctic.html. [new standard: IBCAO (2.5km DBM grid), compiled fr diverse sources, incl. declassified \& Russian]

Jakobsson, Martin, 2002, Hypsometry and volume of the Arctic Ocean and its constituent's seas: Geochemistry Geophysics Geosystems, v. 3, 10.1029/2001GC000302. [2.5km Intl. Bath. Chart Arct. Oc. DBM reveals broad shallow shelves]

Jankowski, D.G., and Squyres, S.W., 1991, Sources of error in planetary photoclinometry: Journal of Geophysical Research, v. 96 , no. E4, p. 20,907-20,922. [quant. anal. of at least 7 , fr spacecraft image, the planet imaged, \& scan-line orientation; good biblio]

Janoo, V.C., 1998, Quantification of shape, angularity, and surface texture of base course materials: Hanover, NH, US Army Corps of Engineers Cold Regions Research \& Engineering Laboratory, CRREL Special Report 98-1, 22 p.;

http://www.crrel.usace.army.mil/techpub/CRREL_Reports/reports/SR98_01.pdf. [reviews direct \& indirect morphometric methods, incl. Wright 1955] 
Jansma, Pamela, Mattioli, Glen, Matias, Audeliz, and Harding, David, 1999, Northeastern Caribbean topography gets a digital upgrade from laser altimetry: Eos, Transactions, American Geophysical Union, v. 80, no. 43, p. 511. [SLICER (Scanning LIDAR Imager of Canopies by Echo Recovery) data corrects DEMs by removing vegetative cover]

Jayko, A.S., 1997, Digital geomorphic investigation, in U.S. Geological Survey, Investigation of the San Bruno Fault near the extension of the Bay Area Rapid Transit line from Colma to San Francisco International Airport, San Mateo County, California: U.S. Geological Survey Open-file Report 97-429, p. 26-55. [15-m DEM from 4 mid-19th C. topo maps; shaded relief, slope, curv., profiles]

Jayko, A.S., 2000, Digital analysis, p. 7-8 in Bonilla, M.G., Jachens, R.C., Jayko, A.S., Wentworth, C.M., and McGarr, A.F., The demise of the San Bruno Fault: California Geology, v. 53, no. 2, p. 419. [15-m DEM from 4 mid-19th C. topo maps; shaded relief, curv., profiles]

Jelinek, H.F., Jones, C.L., and Warfel, M.D., 1998, Is there meaning in fractal analysis?, in Standish, Russell, and seven others, eds., Complex Systems '98, Complexity Between the Ecos-From Ecology to Economics, 30 Nov.-3 Dec., Univ. NSW, Sydney, Australia, Proceedings: Complexity International (ANU, Canberra), v. 6; http://www.csu.edu.au/ci/vol06/jelinek/jelinek.html. [clarifies semantics of 'fractal', often used ignoring principles of scaling theory; need linguistic template to communicate across disciplines]

Jenco, Marián, 1993, The morphometric analysis of georelief in terms of a theoretical conception of the complex digital elevation model of georelief: Universitas Comeniana, Univerzita Komenského, Bratislava, Geographica Nr. 33, p. 133-153. [Krcho-type analysis of topo. as a random field]

Jennings, P.J., and Siddle, H.J., 1998, Use of landslide inventory data to define the spatial location of landslide sites, South Wales, UK, in Maund, J.G., and Eddleston, Malcolm, eds., Geohazards in Engineering Geology: London, The Geological Society, Engineering Geology Special Publication no. 15, p. 199-211. [shallow slides: slope $>24^{\circ}$, nr. coal, 1 ha, $90 \mathrm{~m}$ long; deep-seated harder to char.; >10ha, whole hillside, longer than $250 \mathrm{~m}]$

Jet Propulsion Laboratory, 1997, DEM auxiliary datasets preparation plan-digital elevation mapping support to the EOS/AM-1 platform: Pasadena, CA, California Institute of Technology, JPL D-13508, release 2. 65 p. [30' GTOPO30 spacing met requirements set up here]

Jezek, K.C., Liu, Hongxing, Zhao, Zhiyuan, and Li, Biyan, 1999, Improving a digital elevation model of Antarctica using radar remote sensing data and GIS techniques: Polar Geography, v. 23, no. 3, p. 185-200. [successful upgrade, but more remains to be done]

Jiao, K.Q., 1981, Cross-section of glacial valley at the head of Urumqi River, Tian Shan (in Chinese): Journal of Glaciology and Geocryology, v. 3, p. 92-96. [fits power-law model]

Jimenez, J.A., Maia, L.P., Serra, Jordi, and Morais, Jader, 1999, Aeolian dune migration along the Ceará coast, north-eastern Brazil: Sedimentology, v. 46, no. 4, p. 689-701. [h/W \& L/W relations (largest barchans yet) are linear]

Jiskoot, Hester, Boyle, Paul, and Murray, Tavi, 1998, The incidence of glacier surging in Svalbard-evidence from multivariate statistics: Computers and Geosciences, v. 24, no. 4, p. 387399. [logit regr. on 13 var. $n=504$; glacier length, sfce slope \& lithology best pred.]

Johansson, Magnus, 1999, Analysis of digital elevation data for paleosurfaces in south-western Sweden: Geomorphology, v. 26, no. 4, p. 279-295. [3 surfaces interpr. fr. DEM trend-srfce \& rel \& abs relief]

Johansson, Magnus, Olvmo, Mats, and Söderström, Mats, 1999, Application of digital elevation and geological data in studies of morphotectonics and relief-a case study of the sub-Cambrian 
peneplain in south-western Sweden: Zeitschrift für Geomorphologie, v. 43, no. 4, p. 505-520. [trend-surface \& distance-weight. moving ave. for 50-m National DEM]

Johns Hopkins University, 1952, The effects of terrain on battlefield visibility (SECRET): Operations Research Office, Technical memorandum ORO-T-161, paging unknown. [no info; likely is early quant. line-of-sight research]

Johns Hopkins University, 1955, Limitations imposed by topography on line-of-sight surveillence and communication (CLASSIFIED): Operations Research Office, Technical memorandum ORO-T-332, paging unknown. [LOS; no details]

Jomelli, Vincent, 1997, Géodynamique des dépôts d'avalanches-analyses morphométriques et sédimentologiques (in French): doctoral thesis, Univ. Denis Diderot de Paris 7, 252 p. [longitud. profiles, slope, concavity index, distance from apex; 20 deposits]

Jomelli, Vincent, 1999, Dépôts d'avalanches dans les Alpes Françaises-géométrie, sédimentologie et géodynamique depuis le Petit âge Glaciaire (in French w English abstract \& fig. captions): Géographie Physique et Quaternaire, v. 53, no. 2, p. 199-209. [longitud. profiles, slope, concavity index, distance from apex; 20 deposits]

Jomelli, Vincent, and Francou, Bernard, 2000, Comparing the characteristics of rockfall talus and snow avalanche landforms in an Alpine environment using a new methodological approach-Massif des Ecrins, French Alps: Geomorphology, v. 35, nos. 3-4, p. 181-192. [slope freq.; slope/distance; clast fabric \& sorting]

Jones, C.B., 1997, Surface modeling and spatial interpolation, Chapter 12 in Geographical Information Systems and Computer Cartography: Harlow, UK, Addison Wesley Longman, p. 197213. [textbook; DEM-based examples; good summary]

Jones, C.B., Kidner, D.B., and Ware, J.M., 1994, The implicit triangulated irregular network and multiscale databases: The Computer Journal, v. 37, no. 1, p. 43-57. [can retrieve contours \& form lines from multi-scale line tree (MSLT) edge file]

Jones, J.A.A., 1978, The spacing of streams in a random-walk model: Area (London), v. 10, no. 3, p. 190-197. [no info]

Jones, K.H., 1998, A comparison of algorithms used to compute hill slope as a property of the DEM: Computers and Geosciences, v. 24, no. 4, p. 315-323. [Fleming-Hoffer (1979) \& Horn (ARC/INFO GRID) best of 8 methods; max. slope = worst]

Jones, N.L., Kennard, M.J., and Zundel, A.K., 2000, Fast algorithm for generating sorted strings: Computers and Geosciences, v. 26, no. 7, p. 831-837. [randomly sorts contour segments; faster than contour tracing]

Jones, Richard, 2002, Algorithms for using a DEM for mapping catchment areas of stream sediment samples: Computers and Geosciences, v. 28, no. 9, p. 1051-1060. [efficient 'priority-first-search weighted-graph' algorithm enforces drainage continuity for both pits \& flat terrain \& improves on others (reviewed)]

Jordan, M.-E.-C., 1872a, Sur les lignes de faîte et de thalweg (in French; on ridge \& drainage lines): Comptes Rendus Hebdomadaires des Séances de l'Académie des Sciences, v. 74, no. 23, p. 1457-1459. [mathematician; his contribution, a series of discussions with Boussinesq, summarized by López 1997: at a valley bottom, the only way to identify the terrain slope-line where others converge is to observe its origin-at a saddle point or a double inflection point of the level curves, taking into account channels along ravines; see also Rieger 1997, who prefers Jordan's def. to Rothe 1915] 
Jordan, M.-E.-C., 1872b, Sur les lignes de faîte et de thalweg; réponse aux observations de M. Boussinesq (in French; on ridge \& drainage lines; reply to ... M. B.): Comptes Rendus Hebdomadaires des Séances de l'Académie des Sciences, v. 75, no. 11, p. 625-627. [response to Boussinesq's 1872b criticism; see remarks for Jordan 1872a]

Jordan, M.-E.-C., 1872c, Nouvelles observations sur les lignes de faîte et de thalweg (in French; new obs. on ridge \& drainage lines): Comptes Rendus Hebdomadaires des Séances de l'Académie des Sciences, v. 75, p. 1023-1025. [see remarks for Jordan 1872a]

Jorgeson, Jeff, Freeman, G.E., Johnson, B.E., and, Nelson, Jim, 1998, Hydrologic modeling of West Fork Cedar River Watershed using GEOSHED automated drainage analysis (abs.), in Hallam, C.A., and Salisbury, J.M., eds., GIS Applications in Water Resources Research-American water Resources Annual Meeting, Chicago III, November 6-10, 1994: U.S. Geological Survey, Open-file Report 98-751, p. 8. [DEM-to-watershed transformation on 3' DEM in GRASS]

Journel, A.G., Kyriakidis, P.C., and Mao, Shuguang, 2000, Correcting the smoothing effects of estimators-a spectral postprocessor: Mathematical Geology, v. 32, no. 7, p. 787-813. [results from DEM verify theory of spatial interpolation by autocovariance]

Jovanovíc, P.-S., 1940, Les profils fluviatiles en long, leurs formes et leurs génèses. Essai de méthodes morphogénétiques nouvelles (in French): Skopje and Paris (Armand Colin), 196 p. [statistical study of longitudinal stream profiles]

Judge, E.K., and Overton, M.F., 2001, Remote sensing of barrier island morphology-evaluation of photogrammetry-derived digital terrain models: Journal of Coastal Research, v. 17, no. 1, p. 207220. [101 surveyed dune \& beach profiles compare well w/ DEM profiles]

Junkins, J.L., Jancaitis, J.R., and Miller, G.W., 1972, Smooth Irregular Curves: Photogrammetric Engineering, v. 38, p. 565-573. [probably still the best method to interpolate along a line past simple linear interpolation]

Kaikko, Johann, 1934, Die Höhenunterschiede (height differences), in Streifigkeit der Landschaft in Ladoga-Karelien mit besonder Berücks. ihrer Abhängigkeit vom Felsuntergrund: Fennia, v. 58, no. 4 , p. 24, map $6,1 / 1 \mathrm{M}$. [5 km squares, $1510-\mathrm{m}$ relief intervals]

Kaitanen, Veijo, 1975, Composition and morphotectonic interpretation of the Kiellajohka drainage basin, Finnish Lapland: Fennia, v. 140, 54 p. $\quad$ [applies new quant. methods to analysis of fluvialrelief evolution]

Kammerer, Peter, 1986, Verbesserung der morphometrischen Erfassung des Reliefs mit Hilfe des Digitalen Geländemodells (in German; Improved morphometric understanding of relief with the aid of DEMs): Mitt. der Geographischen Gesellschaft in München, v. 71, p. 57-79. [no info]

Kammerer, Peter, 1990, Die Verarbeitung von Geländehöhendaten des Bayerischen Landesvermessungsamtes auf dem PC (in German; processing Bavarian Office for Land Surveying's DEM on the PC): Mitt. der Geographischen Gesellschaft in München, v. 75, p. 21-29. [no info]

Kane, Phillip, 1978, Origins of valley asymmetry at Sarah Canyon, California: Yearbook of the Association of Pacific Coast Geographers, v. 40, p. 103-115. [microclim. \& veg. type \& density; topo. diffs. incl. drainage area, density, bifurc. ratio, max. slope gradient, mean slope \& channel gradient]

Kanisawa, Satoshi, and Yokoyama, Ryuzo, 1999, Extraction of geologic information from digital elevation map of 50m-mesh-application of slope and openness maps to the Kitakami Mountains 
(in Japanese): Chisitsu News, no. 542, p. 31-38. [reticulate structure of joint pattern revealed clearly for 1 st time by 'openness']

Kant, Immanuel, 1802, Physische Geographie (in German), F.T. Rink, ed.: Königsberg, Göbbels \& Unzer, v. 1, 312 p., v. 2, 248 p.; republished 1923 as Kant's Gesammelte Schriften, in Akad. der Wissenschaften zu Berlin, v. 9, p. 151-436. [among earliest quant. geomorph., see notes for Kant 1803; the only edition authorized by Kant; contents of lectures date to 1775 (v. 1) and 1759 (v. 2)]

Kant, Immanuel, 1803, Physische Geographie (in German): Mainz \& Hamburg, ed. Gottfried Vollmer, v. 3 (of 6, v. 1 in 1801), section 1, p. 18 . [one of earliest morphometric observations, namely, tributaries normally meet main river at $45^{\circ}$ (p. 18); cf Playfair 1802, p. 113-14; Kant among 1 st to advocate land quantification beyond mere listing surface extent, height, \& depth; Kant never traveled but his collected geographic observations by others (he constantly entertained intellectual guests) were highly influential. Kant also infl. J.H. Schröter 1791, 1802. Defects of Vollmer's edition of Kant (only Rink 1802 ed. is authoritative; see Hartshorne 1939, The Nature of Geography, Annals AAG, $29 / 3$ \& 4, p. 38-39) do not necessarily invalidate attribution of the $45^{\circ}$ 'rule' (angle is variable) to Kant; lectures on which books were based date to mid-1700's.]

Kao, R.C., 1963, The use of computers in the processing and analysis of geographic information: Geographical Review, v. 53, p. 530-547. [early advocate of automated spatial data handling]

Kar, Amal, 1998, Present-day mobile crescentic dunes in the Thar desert, India, in Alsharhan, A.S., Glennie, K.W., Whittle, G.L., and Kendall, C.G.St.C., eds., Quaternary Deserts and Climatic Change: Balkema, Rotterdam, p. 155-164. [1 barchan; shape changes w/ season \& degree of development]

Kar, Amal, Tsunekawa, Atsushi, and Miyazaki, Tadakuni, 1998, Potentiality of global positioning system in sand dune measurement-a case study from the Thar desert, India, in Alsharhan, A.S., Glennie, K.W., Whittle, G.L., and Kendall, C.G.St.C., eds., Quaternary Deserts and Climatic Change: Balkema, Rotterdam, p. 433-438. [1st -ever landform from GPS?; 9122 good elevs for 1 parabolic dune; took $6 \mathrm{hrs}$; 1 -m $\mathrm{Cl}$ map from DEM]

Kargel, J.S. 1986, Morphologic variations of Martian rampart crater ejecta and their dependencies and implications, in Abstracts of papers submitted to the Lunar and Planetary Science Conference, 17th, March, Houston, TX, The Lunar and Planetary Institute: Lunar and Planetary Science XVII, p. 410-411. [the old area/perimeter relation (see Woronow \& Mutch 1980); calc. 'lobateness' = $\mathbf{P} /(4 \pi \mathbf{A})^{0.5}$ for 538 craters]

Karlekar, S.N., 1995, Keskar, Umesh, The quantitative assessment of a few landslides around Chiplun and Sangameshwar (Maharashtra): Geographical Review of India, v. 57, no. 1, p. 1-19. [PCA: 26 attributes \& 15 sites; major var.= height, 'spread' \& 'ground length']

Kastrop, J.E., 1949, Sun Oil Company's mobile elevation meter: World Oil, v. 128, no. 13, p. 76-80. [3-wheel trailer; electro-mechanical slope integratin system; elev. accuracy is fraction of a foot over several miles; less acc. in rough terrain]

Kasugaya, Nobumasa, 1981, A method of the morphometry by the application of the mechanical quadratures (in Japanese with English abstract): Transactions, Japanese Geomorphological Union, v. 1 , no. 2 , p. 135-149. [8-point terrain-ruggedness index: true area/map area?]

Kasugaya, Nobumasa, and Chikatsu, Hirofumi, 1981, Some examples of the application of the mechanical quadratures to morphometry (in Japanese with English abstract): Transactions, Japanese Geomorphological Union, v. 1, no. 2, p. 151-164. [n=10; ruggedness index: landform volume, evenness] 
Katsube, Keiichi, 2000, Morphometry of mountains based on a 50-m DEM (in Japanese), in Sugimori, H., Aoki, T., Suzuki, Y., and Oguchi, T., eds., Integration of digital measurement methods for the GIS analyses of hilly lands: Nagoya, Chunichi Shinbun, p. 35-37. [similar height/slope relations for diff. rock types in diff. ranges]

Katsube, Keiichi, and Oguchi, Takashi, 1999, Altitudinal changes in slope angle and profile curvature in the Japan Alps-a hypothesis regarding a characteristic slope angle: Geographical Review of Japan, v. 72 (Ser. B), no., 1, p. 63-72. [50m DEM; 3 alt. zones in 3 ranges: $<1 \mathrm{~km}, 1-2.8 \mathrm{~km},>2.8$ $\mathrm{km}]$

Kaufmann, Victor, 1998, Geomorphometric monitoring of active rock glaciers in the Austrian Alps (in German), in International Symposium on High Mountain Remote Sensing and Cartography 4th (HMRSC-4), 19-29 August 1996, Proceedings: University of Karlstad, Austria, Research Report 97/3 Natural Sciences / Technology, p. 97-113. [chapter 6 is on morphometry]

Kaulfuss, W., 1975, Darstellungsmethode und Anwendungsmoeglichkeiten eines Kartogramms der Reliefenergie fuer den Bezirk Dresden (in German; Representation methods \& applicability of a relative-relief map of the Dresden area: Petermanns Geographische Mitteilungen, v. 119, no. 4, p. 317-319. [no info; late use of obsolete term 'reliefenergie']

Kavouras, Marinos, 1989, Vectorization of scanned contour data: Technical Chronicles Á (in Greek), v. 9 , no. 3 , p. 127-149. [no info]

Kawabata, Daisaku, Oguchi, Takashi, and Katsube, Keiichi, 2001, Effects of geology on slope angles in the southern Japanese Alps-a GIS approach: Transactions, Japanese Geomorphological Union, v. 22, n5. 3, p. 827-836. [height/slope relations for 24 rock types fr $55 \mathrm{~m}$ DEM; some rel. to landsliding]

Kawakami, H., and Saito, Y., 1984, Landslide risk mapping by a quantification method, in International Symposium on Landslides, 4th, 16-21 September, Toronto, Proceedings: Rexdale, Ont., Canadian Geotechnical Society, v. 2, p. 535-540. [weighted freqs. of valley density, elev., slope, formation, geol. structure]

Keane, C.M., 1997, Terrain texture and its potential for landform classification in western Piedmont of Maryland: College Park, University of Maryland, unpublished Ph.D. dissertation, 222 p. [no info]

Keber, Dr., 1882, comments (in German) in Günther (1882), p. 146. [the area/perimeter problem]

Keefer, D.K., 1984, Rock avalanches caused by earthquakes-source characteristics: Science, v. 223 , no. 4642 , p. $1288-1290$. [source slope-height $(\min .=150 \mathrm{~m})$ vs. gradient $\left(\min .=25^{\circ}\right)$ for $\mathrm{n}=$ 23]

Kennelly, P.J., and Kimerling, A.J., 2001, Modifications of Tanaka's illuminated contour method: Cartography and Geographic Information Systems, v. 28, no. 2, p. 111-123. [aspect varies by color, slope by contour width]

Kennedy, F.E., Brown, C.A., Kolodny, J., and Sheldon, B.M., 1999, Fractal analysis of hard disk surface roughness and correlation with static and low-speed friction: Transactions of the ASME, v. 121, no. 4, p. 968-974. [2 parameters (by patchwork method) sensitive to surface-finishing processes]

Kenny, F.M. (compiler), 1998, Digital elevation model of the Greater Toronto and Oak Ridges Moraine areas, southern Ontario (chromo-stereo enhancement): Geological Survey of Canada, Open-File Report 3423, 1 sheet, map scale 1:200,000. [paper map from DEM released on CD-ROM a year later] 
Kenny, F.M, Paquette, J., Russell, H.A.J., Moore, A., Hinton, M.J., 1999, Digital elevation model, greater Toronto area, southern Ontario, and Lake Ontario bathymetry: Geological Survey of Canada, Open-File Report 3678, 1 CD-ROM, containing Arc/Info E00, USGS DEM, and Vertical Mapper files. [hydrol. OK DEM fr 1/50 000 database; ARC/INFO TOPOGRID; $30 \mathrm{~m}$ grid, $\pm 3 \mathrm{~m}$ vert.]

Kerenyi, A., 1977, Kulonbozo reliefenergia-abrazolasok es az erozio kapesolata a tokaji Kopaszhegy peldajan (in Hungarian; Methods for presentation of relative relief and erosion on the example of the Kopasz Mt. in Tokaj: Foldrajzi Ertesito (Geographical Bulletin; Budapest), v. 26, nos. 3-4, p. 289-304. [no info]

Kertész, Àdam, 1979, Application of morphometric methods to geomorphological research, in Marosi, S., ed., Applied Geographical Research in the Geographical Research Institute of the Hungarian Academy of Sciences: Abstract no. 21, p. 51-62. [p. $54 \& 62$, defines microrelief by no. contours crossing sample circle]

Kertész, Àdam, and Szilárd, Jenö, 1979, Some problems of slope development reflected in slopeprofile investigations: Geographia Polonica, v. 41, no. 1, p. 21-26. [geomorph. interpr. of detailed field slope-profile char.]

Kervyn, François, 2001, Modelling topography with SAR interferometry-illustrations of a favourable and less favourable environment: Computers and Geosciences, v. 27, no. 9, p. 1039-1050. [obtained usable InSAR DEM from one area but not another (vegetation too dense)]

Kheyfets, B.S., 1958, The use of polynomials for mathematical characterization of topographic complexity (in Russian): Izvestiya Vysshikh Uchebnyh Zavedeny, Geodesiya i Aerophotosyemka, no. 1 , p. $79-86 . \quad$ [no info]

Kidner, D.B., 1991, Digital terrain models for radio path loss calculations: Ph.D. Thesis, The Polytechnic of Wales, 269 p. $\quad$ [results differ by type of DEMs \& its accuracy]

Kidner, D.B., Eynon, Christopher, and Smith, D.H., 2001, Multiscale terrain databases (ext. abs.), in Kidner, D.B., and Higgs, G., eds., GIS Research UK 9th, Annual Conference (GISRUK 2001), 1820 April 2001, University of Glamorgan, Wales, Proceedings: p. 151-153. [hierarch. encodes 131million-point Great Britain DEM by implicit quadtree pyramid]

Kidner, D.B., and Smith, D.H., 1997, Data compression for digital elevation models, in Hodgson, S., Rumor, and Harts, J.J., eds., Joint European Conference on Geographical Information, 3rd, Vienna, Austria, Proceedings: Amsterdam, IOS Press, v. 1, p. 96-105. [review; prediction preprocessing improves performance over GZIP, etc.]

Kidner, D.B., and Smith, D.H., 1997, Storage-efficient techniques for representing digital terrain models, in Kemp, Z.A., ed., Innovations in GIS 4: Edinburgh, Taylor and Francis, p. 25-41. [large datasets are forcing efficiencies in storage]

Kidner, D.B., and Smith, D.H., 1998, Storage-efficient techniques for handling terrain data, in Spatial Data Handling '98 Conference, 11-15 July, Vancouver, BC, Proceedings: p. 373-385. [large datasets are forcing greater efficiencies in storage]

Kidner, D.B., Dorey, M.I., and Smith, D.H., 1999, What's the point? Interpolation and extrapolation with a regular grid DEM, in International Conference on GeoComputation, 4th, Fredericksburg VA, Mary Washington College, 25-28 July, GeoComputation 99:

http://www.geovista.psu.edu/geocomp/geocomp99/Gc99/082/gc_082.htm. [high-order techniques > linear ones; bicubic interpol. $=$ min. for DEMs] 
Kidner, D.B., Sparkes, A.J., Dorey, M.I., Ware, J.M. and Jones, C.B., 2001, Visibility analysis with the multiscale implicit TIN: Transactions in GIS, v. 5, no. 1, p. 19-37. [storage-reduction method applied to viewsheds]

Kidner, D.B., Ware, J.M., Sparkes, A.J. and Jones, C.B., 2000, Multiscale terrain and topographic modelling with the implicit TIN: Transactions in GIS, v. 4, no. 4, p. 361-378. [reduces size needs a lot by storing only vertices \& constraining features at var. scales]

Kieffer, Hugh, Kargel, J.S., and 40 others, 2000, New eyes in the sky measure glaciers and ice sheets: Eos, Transactions of the American Geophysical Union, v. 81, no. 24, p. 265, 270-271. [DEMs fr ASTER stereo coverage will quantify glacier topo. changes]

Kieniewicz, J.M., Chappelow, J.E., and Sharpton, V.L., 2000, Properties of Martian surfaces from the morphology of small impact craters (abs.): Eos Transactions of the American Geophysical Union, $v$. 81, no. 48 (Supplement, P62B-03), p. F780. [use depth/diam. ratios to infer substrate character]

Killian, K., and Kraus, K., 1992, Punkte in topographischen Flächen mit gleicher Geländeneigung (in German; points in topographic surfaces with same slope (?)): Österreichische Zeitschrift für Vermessungswesen und Photogrammetrie, v. 80, no. 1, p. 20-24. [technique to assess \& model contour accuracy]

Kim, Sanghyun, Kim, Kyunghyun, and Jung, Sunhee, 2001, A digital elevation analysis—spatially distributed flow apportioning algorithm (in Korean with English abstract): Journal of Korea Water Resources Association, v. 34, no. 3, p. 241-251. [spatially varied flow-apport. to accomm. A fr upslope cells; channel init. threshold; topography index]

King, D., Bourennane, H., Isambert, M., and Macaire, J.J., 1999, Relationship of the presence of a non-calcareous clay-loam horizon to DEM attributes in a gently sloping area: Geoderma, v. 89, nos. 1-2, p. 95-111. [20X20m DEM; gradient \& aspect dominant; wind, not $\mathrm{H} 2 \mathrm{O}$, = major process]

King, G.Q., 1982, Morphometry of Great Basin playas: Salt Lake City, UT, University of Utah, unpublished Ph.D. dissertation, 137 p. [drainage basins, morphometry, statistical analysis]

Kirby, Eric, and Whipple, Kelin, 2001, Quantifying differential rock-uplift rates via stream profile analysis: Geology, v. 29, no. 2, p. 415-418. [differences in channel concavity (Nepal) match predictions of stream-power model]

Kirkby, M.J., 1971, Hillslope process-response models based on the continuity equation, in Brunsden, Denys, ed., Slopes, Form and Process: London, Institute of British Geographers, Special Publication no. 3, p. 15-30. [formal introduction of the continuity eqn. into geomorp. modeling]

Kirkby, M.J., 1984, Modelling cliff development in South Wales-Savigear re-reviewed: Zeitschrift für Geomorphologie, v. 28, no. 4, p. 405-426. [continuum eqn. for mass-balance model, incl. landsliding; results agree w/ Savigear 1952]

Kirkby, M.J., 1993, Long term interactions between networks and hillslopes, in Beven, Keith, and Kirkby, M.J., eds., Channel Network Hydrology: New York, Wiley, p. 255-293. [state-of-art progress report, esp. flood forecasting]

Kirkby, M.J., 1997, TOPMODEL-a personal view: Hydrological Processes, v. 11, no. 9, p. 10871098. [future variants may have to sacrifice simplicity for added realism]

Kirkby, M.J., 1999, Translating models from hillslope (1 ha) to catchment $\left(1000 \mathrm{~km}^{2}\right)$ scales, in Diekkrüger, Bernd, Kirkby, M.J., and Schröder, Ulrich, eds., Regionalization in Hydrology, Conference, Technical University of Braunschweig, Germany, 10-14 March, 1997, Proceedings: 
IAHS Publication no. 254, p. 1-12. [current methods primitive; uses DEM elev. in 'flowstrips' to scale up all other params.]

Klein, Micha, 1981, A quantitative approach to the analysis of slope roughness and effective slope angle: Catena, v. 8, p. 281-284. [3 micro-profiles on 3 gravelly field plots; SDC freq.]

Kling, Johan, 1998, The difference between sorted circle and polygon morphology and their distribution in two alpine areas, northern Sweden: Zeitschrift für Geomorphologie, v. 42, no. 4, p. 439-452. [ $n=700$; circles smaller, width/length higher, \& @ higher elev.]

Klinkenberg, Brian, and Clarke, K.C., 1992, Exploring the fractal mountains, in Palaz, I., and Sengupta, S.K., eds., Automated Pattern Analysis in Petroleum Exploration: New York, SpringerVerlag, p. 201-212. [fractal modeling of terrain (variogram method); see Clarke, 1993]

Klostermann, Henning, 1970, Zur geomorphometrischen Kennzeichnung kleiner Einzugsgebiete (in German; morphometric characterization of small catchment areas): Petermanns Geographische Mitteilungen, v. 114, no. 4, p. 241-260. [watershed morphometry, German examples]

Knighton, A.D., 2000, Profile form and channel gradient variation within an upland drainage basin River Noe, Derbyshire: Zeitschrift für Geomorphologie, Supplementband 122, p. 149-164. [7 streams; exponential fcn fits better than linear, log, or power]

Kobrick, Michael, 2002, Planetary phrenology-the lumps and bumps of the Earth: Engineering and Science (California Institute of Technology), v. 65, no. 1, p. 22-31. [the 2000 SRTM presented to a general audience]

Koch, Helge von, 1905, Une méthode géométrique élémentaire pour l'étude de certaines questions de la théorie des courbes planes (in French; simple geometric method to study certain theoretical issues on planar curves): Acta mathematica (Stockholm), v. 30, Octobre, p. 145-174. [origin of fractal theory; not content with the geometric formulation of Weierstrass]

Kochel, R.C., and Piper, J.F., 1986, Morphology of large valleys on Hawaii-evidence for groundwater sapping and comparisons with Martian valleys: Journal of Geophysical Research, v. 91, no. B13, p. E175-E192. [PCA (13 parameters x 53 basins) separates runoff valleys fr. sapping val.]

Koenderink, J.J., and Doorn, A.J. van , 1993, Local features of smooth shapes-ridges and courses, in Geometric Methods in Computer Vision II, v. 2031, SPIE, p. 2-13. [disputes mathematical correctness of contour-to-watershed algorithms]

Koenderink, J.J., and Doorn, A.J. van, 1994, Two-plus-one-dimensional differential geometry: Pattern Recognition Letters, v. 15 , no. 5, p. 439-443. [historical overview of ridge detectors 1st proposed in early 19 th $\mathrm{C}$. to define watersheds]

Koenderink, J.J., and Doorn, A.J. van, 1998, The structure of relief, in Advances in Imaging \& Electron Physics, v. 103, p. 65-150. [review scalar fields on 2D manifolds (relief-contour \& fall curves, ridges \& courses) for computer vision]

Kok, A.L., Blais, J.A.R., and Rangayyan, R.M., 1987, Filtering of digitally correlated Gestalt elevation data: Photogrammetric Engineering and Remote Sensing, v. 53, no. 5, p. 535-538. [attempt (not wholly successful) to fix striped artifacts in Level-1 USGS DEMs]

Konovalov, N.E., 1974, Digital modelling of topographic conditions of a terrain for design of linear constructions (in Russian), in Vasilyev, A.P., ed., Transactions of GiprodorNII, no. 8, Survey and Design of Highways: GiprodorNII, Moscow, p. 21-33. [no info] 
Kophstahl, E., 1988, Automationsgestütztes Erfassen, Verarbeiten und Darstellen topographischer Daten für die Herstellung der Deutschen Grundkarte 1/5000 - Höhe in Niedersachsen (in German; automated entry, processing \& representation of topo. data for making the German 1/5000 base map - height in Lower Saxony): Nachr. Karten- u. Vermessungswesen, I, v. 92, p. 55-59. [no info]

Koristka, Karel, 1861, Bericht über einige im niederen Gesenke und im Marsgebirge ausgeführte höhenmessungen (... on height meas. in the low sinks (sic) \& the Marsgebirge; in German): Vienna, F.B. Geitler, 20 p. [obtaining elev. data; no other info]

Koristka, Karel, 1863, Hypsometrie von Mähren und Österreichisch Schlesien (hypsometry of Moravia \& Austrian Silesia; in German): Brünn, Im commission bei E. Hölzel in Olmütz, 160 p., map. [measurements, quantitative terrain description]

Kossinna, Erwin, 1933, Die Erdoberfläche (in German), in Gutenberg, Beno, ed., Handbuch der Geophysik, v. 2: Berlin, Bornträger, p. 869-954. [broad-scale post-Humboldt hypsometry, etc.]

Kostaschuk, R.A., MacDonald, G.M., and Putnam, P.E., 1986. Depositional process and alluvial fandrainage basin morphometric relationships near Banff, Alberta, Canada: Earth Surface Processes and Landforms, v. 11, p. 471-484. [found 2 types of fans; relations differ by type]

Köthe, Rüdiger, 1988, Versuch einer computergesteuerten morphographisch-prozeßorientierten Reliefanalyse für die bodenkunliche Kartierung (in German): unpublished Dipl. Arb. Lehrstuhl Phys. Geogr., Univ. Hannover, paging unknown. [SARA software package prototype?]

Köthe, Rüdiger, and Lehmeier, Friedmut, 1993, SARA, ein System zur Automatischen Relief-Analyse (in German): Standort, Zeitschrift für Angewandte Geographie (Köln), v. 4, p. 11-21. [software SARA for DEM-based fluvial modeling]

Köthe, Rüdiger, Gehrt, Ernst, and Böhner, Jürgen, 1996, Automatische Reliefanalyse für geowissenschaftliche Kartierungen-derzeitiger Stand und Weiterentwicklungen des Programms SARA (Automatic relief analysis for geoscientific mapping-present status and progress of SARA): Arbeitshefte Geologie (Hannover), v. 1, p. 31-37. [DEM-based package for terrain modeling \& mapping]

Koutaniemi, Leo, 1982, The relationship between relative height and microrelief-Three case studies from northern Finland: Fennia, v. 160, no. 2, p. 277-294. [1/20K maps; $n=3439$; microrelief $=$ no. contour-crossings on sample circle]

Kraak, M.-J., and Ormelling, Ferjan, 1996, Relief (Sect. 5.5), in Cartography-Visualization of Spatial Data: Harlow, UK, Addison-Wesley Longmans, p. 100-108. [textbook; gen'l. info on DEM's \& applics. esp. carto/viz.]

Krabill, W., Frederick, E., Manizade, S., Martin, C., Sonntag, J., Swift, R., Thomas, R., Wright, W., and Yungel, J., 1999, Rapid thinning of parts of the southern Greenland ice sheet: Science, v. 283, p. 1522-1524. [1993 \& 1998 laser altimetry (70-m planes) differenced; error eval.]

Krabill, W., Abdalati, W., Frederick, E., Manizade, S., Martin, C., Sonntag, J., Swift, R., Thomas, R., Wright, W., and Yungel, J., 2000, Greenland ice sheet-high-elevation balance and thinning, Science, v. 289, p. 428-430. [color map from airborne laser altimetry \& GPS]

Kramrisch, F., 1935, Zur Rauhigkeitsbestimmung von Gesteinbruchsflächen (in German; roughness grading of stone aggregate surfaces): Geologie und Bauwesen, v. 7, no. 2, p. 33-59. [industrial morphometry; profiles from sectioned casting; roughness = length of fine-scale profile / length of coarse-scale profile; see Wright 1955] 
Kraus, K., 1994, Visualization of the quality of surfaces and their derivatives: Photogrammetric Engineering and Remote Sensing, v. 60, no. 4, p. 457-462. [graphic means for assessing DEM accuracy \& error]

Kraus, K., and Pfeifer, N., 1998, Determination of terrain models in wooded areas with airborne laser scanner data: ISPRS Journal of Photogrammetry and Remote Sensing, v. 53, no. 4, p. 193-203. [better than photogramm., but derived contours not good enough for geomorph.]

Krcho, Jozef, 1983, Theoretical conception and interdisciplinary application of the complex digital model of relief in modelling bidimensional fields (in Slovak with English abstract): Geograficky Casopis., v. 35, p. 265-291. [terrain segmentation by pos. \& neg. DEM curvature]

Krcho, Jozef, 1986, Geometric forms of the georelief and their hierarchic levels (in Slovak, with English abstract): Geograficky Casopis, v. 38, p. 210-235. [no info, but undoubtedly related to known works]

Krcho, Jozef, 1987, Mathematical properties of the topographical surface of georelief from the viewpoint of morphometric analysis as well as modelling by means of a complex digital model (in Slovak, with English abstract): Geograficky Casopis, v. 39, p. 169-204. [no info, but undoubtedly related to known works]

Krcho, Jozef, 1989, Mathematical properties of the georelief from the viewpoint of geometric forms and its modelling by approximating functions of two variables (in Slovak, with English abstract): Geograficky Casopis, v. 41, no. 1, p. 23-47. [no info, but undoubtedly related to known works]

Krcho, Jozef, 1999, Landscape as a spatially organized system and georelief as a subsystem of landscape-the influence of georelief on spatial differentiation of landscape proceses: http://www.mpsr.sk/slovak/dok/gn/book/45kap/45kap.htm. [online treatise on his random-field approach to geomorphometry, with illustrations \& biblio]

Krebs, Norbert, 1923, Süddeutschland: Leipzig \& Berlin, p. 6 (map), 1/4.5M scale. [2nd relativerelief map of So. Germany; 5 intervals]

Krebs, Norbert, 1928, Karte der Reliefenergie, in Die Ostalpen und das heutige Österreich, v. 1: Stuttgart, plate $5,1 / 2 \mathrm{M}$. [7 relative-relief intervals]

Kreslavsky, M.A., and Head, J.W. III, 1999, Kilometer-scale slopes on Mars and their correlation with geologic units-initial results from Mars Orbiter Laser Altimeter (MOLA) data: Journal of Geophysical Research, v. 104, no. E9, p. 21,911-21,924. [med. slope @ lengths 0.4-25 km; S/L comp.w/ GTOPO30 (slope same)]

Kreslavsky, M.A., and Head, J.W. III, 1999, Morphometry of small shield volcanoes on Venus-implications for the thickness of regional plains: Journal of Geophysical Research, v. 104, no. E8, p. 18,925-18,932. [arithmet. height/diameter stats; small domes; cf Bulwer \&]

Kreslavsky, M.A., and Head, J.W. III, 2000, Kilometer-scale roughness of Mars-results from MOLA data analysis: Journal of Geophysical Research, v. 105, no. E11, p. 26,695-26,711. ['differential slope' vs. $0.6-20 \mathrm{~km}$ base length]

Krumbein, W.C., 1978, Some recent developments in the mathematical geology of stream-channel networks, in Merriam, D.F., ed., Geomathematics-Past, Present, and Prospects: Syracuse, NY, Syracuse University Geology Contributions, No. 5, p. 37-56. [excellent review of Shreve's \& others' topological model 1967-78]

Krümmel, O., 1979, Versuch einer vergleichenden Morphologie der Meeresräume (attempt at a comparative morphology of sea areas, in German): Leipzig, publ. \& paging unknown. 
[area/perimeter relation; Küstengliederung (coastal arrangement) in $\%$, e $=(100 / \mathrm{U})(\mathrm{U}-\mathrm{K})$; for $\mathrm{K}$ see Rohrbach, 1890]

Krupnik, Amnon, 2000, Accuracy assessment of automatically derived digital elevation models from SPOT images: Photogrammetric Engineering and Remote Sensing, v. 66, no. 8, p. 1017-1023. [good overall, some problems in agricultural land \& moutains; ref. DEM 1-2m elev. acc.]

Krzyszkowski, Dariusz, and Stachura, Renata, 1993, Morphologic effects of neotectonic movements in the Walbrzych foothills, Middle Sudety Mountains, SW Poland (in Polish with English summary \& figure captions): Folia Quaternaria, v. 64, p. 71-81. [relative-relief \& slope maps]

Kudrnovská, O., 1975, Morfometricke metody a jejich aplikace pri fyzickogeograficke regionalizaci (in Czech; morphometric methods \& their application to physico-geographical regionalization): Studia Geographica (Brno), v. 45, 182 p. [86 refs, landform description, quant. geomorph.]

Kuenen, Ph.H., 1935, Geological interpretation of the bathymetrical results, in The Snellius Expedition in the Eastern Part of the Netherlands East Indies 1929-1930: Leyden, E.J. Brill, v. 5, Geological Results, pt. 1, p. 62-69. [submarine slopes of composite andesite cones average $25^{\circ}$ ]

Kugler, Hans, 1965, Aufgaben, Grundsätze und methodische Wege für großmaßstabiges geomorphologisches Kartieren (in German): Petermanns Geographische Mitteilungen, v. 109, no. 4, p. 241-257. [slope \& relief as components of large-scale geomorphologic maps]

Kühni, A., and Pfiffner, O.A., 2001a, Drainage patterns and tectonic forcing-a model study for the Swiss Alps: Basin Research, v. 13, no. 2, p. 169-197. [broad-scale SPM (surface-process modeling) of mtn. topography on $100 \times 1001-\mathrm{km}$ grid cells yields var. relief \& drainage patterns]

Kühni, A., and Pfiffner, O.A., 2001b, The relief of the Swiss Alps and adjacent areas and its relation to lithology and structure-topographic analysis from 250-M DEM: Geomorphology, v. 41, no. 4, p. 285-307. [broad-scale neo-orometry fr GTOPO30; rel. to erosion patterns; compare elev., relief, \& slope; summit-level map]

Kumar, Muneendra, 2000, A WGS'84 orthometric height of Mount Everest: GPS World, v. 11, no. 10, p. 46-48. $\quad[29,028 ' / 8850 \mathrm{~m} \pm 2 \mathrm{~m}, 1$ sigma uncertainty]

Kumar, Praveen, Verdin, K.L., and Greenlee, S.K., 2000, Basin level statistical properties of topographic index for North America: Advances in Water Research, v. 23, no. 6, p. 571-578. [params of TOPMODEL wetness index for 5020 NA basins fr. GTOPO30 DEM]

Kusumayudha, S.B., Zen, M.T., Notosiswoyo, Sudarto, Gautama, R.S., 1997, Analisis fraktal aliran Kali Oyo di Pegunungan Selatan Jawa Tengah, kendali litologi dan struktur geologi: J. Teknol Mineral, v. 4, no. 2, p. 71-86. [see same authors, 2000]

Kusumayudha, S.B., Zen, M.T., Notosiswoyo, Sudarto, Gautama, R.S., 2000, Fractal analysis of the Oyo River, cave systems, and topography of the Gunungsewu karst area, central Java, Indonesia: Hydrogeology Journal, v. 8, no. 3, p. 271-278. [D (Oyo r.) $=1.0-1.5$, cave rivers $=1.04-1.08$, topo. $=1.5-1.7]$

Kweon, I.S., and Kanade, Takeo, 1994, Extracting topological terrain features from elevation maps: Computer Vision, Graphics, and Image Processing / Image Understanding, v. 59, no. 2, p. 171182. [definition of ridges \& valleys based on 3 derivatives of elev.; 'topographic change trees' (3 types) descr. surface 'connectability']

Kyriakidis, P.C., Shortridge, A.M., and Goodchild, M.F., 1999, Geostatistics for conflation and accuracy assessment of digital elevation models: International Journal of Geographical Information Science, v. 13, no. 7, p. 677-707. [used higher-resolution DEM as 'ground truth'] 
La Barbera, P., and Lanza, L.G., 2000, Comment on 'A physical explanation of the cumulative area distribution curve' by Hemantha Perera and Garry Willgoose: Water Resources Research, v. 36, no. 3, p. 815-817. [gets different value of phi for CAD based on Tokunaga stream numbering]

La Barbera, P., and Lanza, L.G., 2001, On the cumulative area distribution of natural drainage basins along a coastal boundary: Water Resources Research, v. 37, no. 5, p. 1503-1509. [Horton analysis of independent conterminous basins outlet to the sea]

Lado Liñares, M., Taboada Castro, M.M., and Dieguez Villar, A., 1998, Relación entre índices de rugosidad-tortuosidad, pendiente límite, distancia límite y rugosidad aleatoria (Relations between roughness indices-tortuosity, limiting slope, limiting difference, and random roughness, in Spanish): Cadernos do Laboratorio Xeolóxico de Laxe (Univ. Coruña), v. 23, p. 151-164. [microtopo of cultivated fields; pinmeter; slope \& difference most highly correlated]

Lague, D., Davy, Philippe, and Crave, Alain, 2000, Estimating uplift rate and erodability from the area-slope relationship-examples from Brittany (France) and numerical modelling: Physics and Chemistry of the Earth (A), v. 25, no. 6-7, p. 543-548. [spatially averaged uplift ratio computed fr 250-m DEM]

Lake, Philip, 1928, On hill slopes: Geological Magazine, v. 65, no. 3, p. 108-116. [early detailed slope profiles $(n=9)$ for geomorph.; arcs fit circle or parabola]

Lancaster, Nicholas, 1981, Aspects of the morphometry of linear dunes of the Namib Desert: South African Journal of Science, v. 77, no. 8, p. 366-368. [orientation statistics]

Lancaster, S.T., and Bras, R.L., 2002, A simple model of river meandering and its comparison to natural channels: Hydrological Processes, v. 16, no. 1, p. 1-26. [based on planform sinuosity; more like cellular models; yields compound bends \& multibend loops]

Lane, S.N., 2000, The measurement of river channel morphology using digital photogrammetry: Photogrammetric Record, v. 16, no. 96, p. 937-961. [review \& progress rept.; now underutilized; data qual. a problem]

Lane, S.N., James, T.D., and Crowell, M.D., 2000, Application of digital photogrammetry to complex topography for geomorphological research: Photogrammetric Record, v. 16, no. 95, p. 793-821. [detailed quality \& error analysis, not geomorph. applics. per se]

Langbein, W.B., 1964, Profiles of rivers of uniform change: U.S. Geological Survey, Professional Paper 501-B, 4 p. $\quad$ [concavity = 2A/F; F, fall; A, height diff. of straight line \& profile in middle]

Laplace, P.S. de, 1825, no title for entry (in French), in Traité du Mécanique Céleste: J.B.M. Duprat, Paris, v. 5, book 11, chap. 1, p. 13, 14, 16 (var. cit.); see also, 4-v Engl. transl. by Nathaniel Bowditch, 1829-39, Boston MA. [Assuming conditions of equilibrium, deduced mean ocean depth $=$ mean height $(\mathrm{asl})$ of continents $(3280 \mathrm{ft})$; this error inspired von Humboldt's (\& others') calc. of mean height of continents]

Larsen, M.C., and Parks, J.E., 1998, Map showing landslide susceptibility in the Comerío Municipality, Puerto Rico: U.S. Geological Survey, Open-file Report 98-566, scale 1/20,000.

[slope+elev.+aspect+land use+debris-flow meas. $=3$ classes]

Lastochkin, A.N., 1987, Morphometrical investigations in geomorphology. I. Classification of morphometric constructs and characteristics (in Russian, v. brief English summary): Vestnik Leningradskogo Universiteta; Geologiia, Geografii, Serie 7, 1987, no. 3, p. 44-53. [proposed classification; long table; 36 refs. incl. Krcho \& Pal] 
Lastochkin, A.N., 1988a, Morphometrical investigations in geomorphology. II. Studies of morphological features of the Earth's surface (in Russian, v. brief English summary): Vestnik Leningradskogo Universiteta; Geologiia, Geografii, Serie 7, 1988, no. 1, p. 37-50. [reviews range of morph. attributes; cites Krcho; 27 refs.]

Lastochkin, A.N., 1988b, Morphometrical investigations in geomorphology. III. Studies of the morphology of constituent parts of the Earth's surface (in Russian, v. brief English summary): Vestnik Leningradskogo Universiteta; Geologiia, Geografii, Serie 7, 1988, no. 3, p. 50-64. [further? reviews range of morph. attributes; 36 refs.]

Lazarevich, K.S., 1992, The hypsometric map as a special geomorphological map: Mapping Sciences and Remote Sensing, v. 29, p. 163-171. [transl. fr. Russian in Geomorfol., no. 2, p. 38-45, 1991]

Leberl, F.W., 1980, Application of imaging radar to mapping, in Radar geology-an assessment, report of the Radar Geology Workshop: Snowmass, CO, 16-20 July 1979, Jet Propulsion Laboratory Publication 80-61, p. 307-335. [reviews topographic mapping fr. radargrammetry; large biblio.]

Leberl, F.W., 1998, Radargrammetry, Chapter 4 in Henderson, F.M., and Lewis, A.J., eds., Manual of Remote Sensing (3rd ed.), v. 2, Principles and Applications of Imaging Radar: New York, John Wiley \& Sons, p. 183-269. [state-of-art review; refs occupy p. 252-269]

Leblanc, F., 1842, Observations sur le maximum d'inclinaison des talus dans les montagnes (in French): Bulletin de la Société Géologique de la France, v. 14, p. 85-98. [126 values from var. sources; among earliest systematic measurements of slope]

Lecce, S.A., 1991, Influence of lithologic erodibility on alluvial fan area, western White Mountains, California and Nevada: Earth Surface Processes and Landforms, v. 16, no. 1, p. 11-18. [power functions relating fan to basin area]

Lee, Jay, 1994, Digital analysis of viewshed inclusion and topographic features on digital elevation models: Photogrammetric Engineering and Remote Sensing, v. 60, no. 4, p. 451-456. [defines pixel dominance in intervisibility; contrasts peaks, pits, ravines, ridges]

Lee, J.I., and Kim, S.H., 2000, Application of topographic index calculation algorithm considering topographic properties (in Korean with English abstract): Journal of Korea Water Resources Association, v. 33 , no. 3, p. 279-288. [test TOPMODEL by DEM's at 20, 30, 40, $50 \mathrm{~m}$ grids]

Leech, M.L., Egger, A.E., and Howell, D.G., 2002, A guided inquiry approach to learning the geology of the U.S. (abs.): Geological Society of America, Annual Meeting, Denver, CO, 27-30 October, paper no. 154-12; http://gsa.confex.com/gsa/2002AM/finalprogram/abstract_37904.htm. [pedagogic applic. of broad-scale computer visualization combining shaded relief \& geology]

Legates, D.R., and Wilmot, C.J., 1986 Interpolation of point values from isoline maps: American Cartographer, v. 13, no. 4, p. 308-323. [D.H. Douglas' contour to grid method CONSURF better than prior algorithms]

Legendre, Pierre, and Legendre, Louis, 1998, Spatial analysis, Ch. 13 in Numerical Ecology (2nd English ed., 853 p.): Amsterdam, Elsevier, p. 707-785. [statistics, well explained; 'practical handbook \& ref. text']

Lehmann, J.G., 1831, On situation, or the guide for correct representation of the landsurface on topographic maps and plans (in Russian, transl. fr. German): St. Petersburg, 74 p. [no info; may be transl. of Lehmann 1799, who invented hachuring, the basis of analytical (i.e. quant.) hillshading; used slope hachures \& later shadow hachures] 
Lehmann, Otto, 1934, Über die morphologischen Folgen der Wandwitterung (in German; morph. consequences of cliff weathering): Zeitschrift für Geomorphologie, v. 8, p. 93-99. [refinement of Fisher's 1866 theory; added effects of cliff \& scree angles, rock/scree $\vee$ ratio]

Lehmeier, Friedmut, 1993, Auszug des Symbolschlussels Geomorphologie (DARG) (in German: extract from the Geomorphology Data Code (DARG)): Geologisches Jahrbuch, v. F26, no. 2, p. 47135. [see Roeschmann \& Lehmeier 1993; fleshes out detailed system of relief char. in plan \& profile; Kugler, Demek infl.]

Leith, A.C., and McKinnon, W.B., 1991, Terrace width variations in complex Mercurian craters and the transient strength of cratered Mercurian and lunar crust: Journal of Geophysical Research, v. 96, no. E4, p. 20,923-20,931. [after Pearce \& Melosh 1986; uses some Pike 1988 D \& d data; discusses peak recoil vs rim slumping]

Lemmens, M.J.P.M., 1999, Uncertainty in automatically sampled digital elevation models, Ch. 47 in Lowell, Kim, and Jaton, Annick, eds., Spatial Accuracy Assessment-Land Information Uncertainty in Natural Resources: Chelsea, MI, Ann Arbor Press, p. 399-407. [DEM uncertainty poorly known \& sources complex; manual capture breaklines best]

Leopold, L.B., 1970, Review of studies of hillslopes - U.S.A.: Zeitschrift für Geomorphologie, Supplementband 9, p. 57-66. [summarizes some 1960's morphometry]

Lessing, Peter, and Erwin, R.B., 1977, Landslides in West Virginia, in Coates, D.R., ed., Reviews in Engineering Geology, Geological Society of America, v. 3, Landslides: p. 245-254. [summarizes 1976 work; slope concavity \& proximity to other slides assoc. w/ slides, no preferred azimuth]

Lessing, Peter, Kulander, B.R., Wilson, B.D., Dean, S.L., and Woodring, S.M., 1976, Landslide correlations and statistics, pp. 31-40, in West Virginia Landslides and Slide-prone Areas: Morgantown, WV, West Virginia Geological and Economic Survey, Environmental Geology Bulletin No. 15,64 p. \& 28 landslide-susceptibility maps, scale 1:24,000. [slope concavity \& proximity to other slides assoc. w/ slides, no preferred azimuth; analysis of R- \& Q-mode clustering of 39 variables \& 100 slides not well handled]

Lessing, Peter, Messina, C.P., and Fonner, R.F., 1983, Landslide risk assessment: Environmental Geology, v. 5. no. 2, p. 93-99. [2416 W.VA slides; summary diagram incl. bedrock, dip dir., slope, aspect. area, est. curve., proximity other slides, etc.]

Leverington, D.W., Teller, J.T., and Mann, J.D., 2002, A GIS method for reconstruction of late Quaternary landscapes from isobase data and modern topography: Computers and Geosciences, v. 28 , no. 5, p. 631-639. [interpolated isobases subtracted from present topo. \& bathymetry]

Lex, Franz, 1925, Karte der relativen Höhen in Kärnten (in German): Vienna, Kärntner Heimatlas, map 4, 1/1.75M. [5-km separation of points; 7 intervals]

Li, Rongxing, Liu, J.-K., and Felus, Yaron, 2001, Spatial modeling and analysis for shoreline change detection and coastal erosion monitoring: Marine Geodesy, v. 24, no. 1, p. 1-12. [computes DEM surfaces of water \& lake bottom to get shoreline]

Li, Xin, Lu, Ling, Cheng, Guodong, and Xiao, Honglang, 2001, Quantifying landscape structure of the Heihe River Basin, north-west China using FRAGSTATS: Journal or Arid Environments, v. 48, no. 4, p. 521-535. [6 ecoregions delimited fr 9 metrics; technique could be applied to shadedrelief, other topo data?]

Li, Yingkui, Liu, Gengnian, and Cui, Zhijiu, 2001a, Glacial valley cross-profile morphology, Tien Shan Mountains, China: Geomorphology, v. 38, nos. 1-2, p. 153-166. [quadratic eqns better than power law; Rockies differ fr TS; glac. \& fluv. valleys differ quant'ly.] 
Li, Yingkui, Liu, Gengnian, and Cui, Zhijiu, 2001b, Longitudinal variations in cross-section morphology along a glacial valley-a case study from the Tien Shan, China: Journal of Glaciology, v. 47 , no. 157, p. $243-250$. [new, variable width/depth ratio model uses slope \& breadth]

Liang, Chaojun, and Mackay, D.S., 1997, Feature-based optimization of flow directions and upslope areas on grid-based digital elevation models, in GIS/LIS'97, Cincinnati, OH, October, Proceedings: Bethesda MD, ASPRS, p. 45-52. [refined Mackay \& Band 1998 approach by adding rule-based heuristic]

Liang, Chaojun, and Mackay, D.S., 2000, A general model of watershed extraction and representation using globally optimal flow paths and up-slope contributing areas: International Journal of Geographical Information Science, v. 14, no. 4, p. 337-358. ['breadth-first' search + 'feature-based global opt.' gives good DEM-based results in flat terrain]

Lidov, V.P., Setunskaya, L.E., and Khmeleva, N.V., 1956, Study of erosion microforms by quantitative methods, in Rihter, G.D., and Dyachenko, A.E., eds., Agricultural Erosion and Its Control: Soviet Academic Press, Moscow, p. 47-69. [no info]

Lindstrom, Peter, Koller, David, Ribarsky, William, Hodges, L.F., Faust, Nick, and Turner, G.A., 1996, Real-time, continuous level of detail rendering of height fields, in SIGGRAPH'96 Conference, 4-9 August, New Orleans LA, Proceedings: p. 109-118;

<http://www.gvu.gatech.edu/people/peter.lindstrom/papers/siggraph96/>. [important; dynamic DEM display using regular grid; triangular-bintree mesh \& bottom-up vertex-reduction; some similarities to later ROAM algorithm]

Link, L.E., 1969, Capability of airborne laser profilometer to measure terrain roughness, in Symposium on remote sensing of environment, 6th, Ann Arbor, MI, Proceedings: v. 1, p. 189-196. [12 varied test sites; may be OK if sources of error eliminated]

Linnett, L.M., Clarke, S.J., Graham, C., and Langhorne, D.N., 1991, Remote sensing of the sea-bed using fractal techniques: Journal of Electronics and Communication Engineering, v. 3, no. 5, p. 195-203. [classified images of the seafloor by fractal segmentation]

Little, J.J., and Shi, Ping, 1998, Structural lines, TINs, and DEMs, in International Symposium on Spatial Data Handling 8th, 11-15 July, Vancouver BC, Proceedings: p. 627-636. [structural lines, based on local curvature not water flow, are skeleton for TIN]

Little, J.J., and Shi, Ping, 2001, Structural lines, TINs, and DEMs, in van Kreveld, M., ed., Algorithmica, v. 30, no. 2, Special Issue on Algorithms for Geographic Information, p. 243-263. [structural lines, based on local curvature not water flow, are skeleton for TIN]

Liu, Hongxing, 1999, Generation and refinement of a continental scale digital elevation model by integrating cartographic and remotely sensed data-a GIS-based approach: Columbus $\mathrm{OH}$, Ohio State University, unpublished Ph.D. thesis. [Antarctica; supporting details for Liu et al. 1999 JGR paper]

Liu, Hongxing, and Jezek, K.C., 1999, Investigating DEM error pattern by directional variograms and Fourier analysis: Geographical Analysis, v. 31, no. 3, p. 249-256. [varies; $\pm 2-100 \mathrm{~m}$ at 0.2-5km res.; used their Antarctic data]

Liu, Hongxing, Jezek, K.C., and Li, Biyan, 1999, Development of an Antarctic digital elevation model by integrating cartographic and remotely sensed data-a geographic information system based approach: Journal of Geophysical Research, v. 104, no. B10, p. 23,199-23,213. [best yet; 0.2$5 \mathrm{~km}$ res. $\pm 2-100 \mathrm{~m}$.; derived shaded relief \& flow lines] 
Liu, Xi-lin, 2000, Approaches to risk assessment of debris flow (in Chinese): Journal of Mountain Science, v. 18, no. 4, p. 341-345. [basin A \& R, channel L, drainage density, active channel proportion]

López, A.M., 1997, Ridge/valley-like structures-creases, separatrices, and drainage patterns, in CVonline: On-Line Compendium of Computer Vision, R. Fisher, ed., online Oct. 8, 1997; $<$ http://www.dai.ed.ac.uk/CVonline/LOCAL_COPIES/LOPEZ/cvonline.html>. [review of descriptive-geometric fundamentals of drainage nets, their 19th C. developmental history, \& how \& why they relate closely to computer vision \& (briefly) to the DEM-to-watershed transformation; English translation from the Spanish]

López, A.M., 1999, Multilocal methods for ridge and valley delineation in image analysis: Ph.D thesis, Universitat Autónoma de Barcelona, 345 p. $<$ http://www.cvc.uab.es/shared/staff/all_staff/antonio.htm>. [close coupling of image analysis/computer vision, here applied to medical imaging, with drainage nets \& their extraction from DEMs]

López, A.M., 1999, Delineation of drainage patterns in gridded DEMs, Ch. 5 in Multilocal methods for ridge and valley delineation in image analysis: Ph.D thesis, Universitat Autónoma de Barcelona, p. 125-167; <http://www.cvc.uab.es/shared/staff/all_staff/antonio.htm>. ['free-flow' algorithm uses flowlines rather than pixel-to-pixel routing]

López, A.M., Lumbreras, F., Serrat, Joan, and Villanueva, J.J., 1999, Evaluation of methods for ridge and valley detection: IEEE Transactions on Pattern Analysis and Machine Intelligence (PAMI), v. 21, p. 327-335. [descriptive geometry of drainage nets in machine vision; see López 1997]

López, Carlos, 2002, An experiment on the elevation accuracy improvement of photogrammetrically derived DEM: International Journal of Geographical Information Science, v. 16, no. 4, p. 361-375. [technique to identify elevation outliers]

López-Blanco, Jorge, and Villers-Ruiz, Lourdes, 1995, Delineating boundaries of environmental units for land management using a geomorphological approach and GIS-a study in Baja California, Mexico: Remote Sensing of the Environment, v. 53, no. 2, p. 109-117. [DEM \& other ingredients; 32 landscape units fr. overlay comparison]

Lopéz-Santoyo, A., 1978, Structural relief interpretation through profile analysis, in Davis, J.C., ed., Computer Mapping for Resource Analysis, a CoGeoData Conference, Kansas Geological Survey, University of Kansas, and Instituto de Geografía de la UNAM, Mexico, Proceedings: p. 168-182. [no info]

Loveland, T.R., and Ramey, Ben, 1986, Applications of U.S. Geological Survey Digital Cartographic Products, 1979-1983: U.S. Geol. Survey, Bulletin 1583, 44 p. [several use 7.5' DEM's, Digital Terrain Tapes, \& Arc-second DEM's]

Lu, Zhong, Mann, Dörte, Freymueller, J.T., and Meyer, D.J., 2000, Synthetic aperture radar interferometry of Okmok volcano, Alaska-radar observations: Journal of Geophysical Research, v. 105 , no. B5, p. 10,791-10,806. [high-accuracy DEM fr tandem images better than 90m DEM fr $1 / 250 \mathrm{~K}$ map]

Lukas, K., and Weibel, Robert, 1995, Assessment and improvement of methods for analytical hillshading, in International Cartographic Conference, 17th, Barcelona, Proceedings: p. 2231-2240. [no info]

Luo, Wei, 2000, Quantifying groundwater-sapping landforms with a hypsometric technique: Journal of Geophysical Research, v. 105, no. E1, p. 1685-1694. [5 parameters of the hyps. curve differentiate fluvial fr. sapping basins] 
Luo, Wei, 2000, Review of RiverTools, version 2.0, Research Systems, Inc., 4990 Pearl East Circle, Boulder, CO 80301: Computers and Geosciences, v. 26, no. 2, p. 237-238. [easy to use, excellent visualiz.; needed improvements typical of early version software]

Luo, Wei, 2001, LANDSAP-a coupled surface and subsurface cellular automata model for landform simulation: Computers and Geosciences, v. 27, no. 3, p. 363-367. [based on model of Chase 1992 to model Martian channel devel.]

Luo, Wei, 2002, Hypsometric analysis of Margaritifer Sinus and origin of valley networks: Journal of Geophysical Research. v. 107E, no. E10, 10.1029/2001JE001500. [MOLA data; most basins have hypso. char. of groundwater sapping, some fluvial]

Luoma-Aho, Seppo, 1982, Landforms and morphostructure in Koillismaa, Finland: Fennia, v. 160, no. 1, p. 1-41. [1/20K elevs etc. gridded at $1 \& 2 \mathrm{~km}$; made maps of elev, relative relief, form density, aspect, geology; correl. matrices]

Lüttig, Gerd, 1953, Eisrand und Reliefenergie: Neues Jahrbuch für Geologie und Palaeontologie Monatshefte (Stuttgart), v. 1, p. 16-20. $\quad$ [position of Saale ice margin determined fr contrast in relative relief]

Lynch, Steve, 2002, Digital elevation models and spatial resolution: South African Journal of Science, v. 98. no. 5/6, p. 219-222. [tutorial; eval. 3 S.A. DEMs; error considerations, etc.]

Lynn, Greg, 1993, Probable geometries-the architecture of writing in bodies: Any (New York, the Anyone Corp.), May-June, v.1 no. 0. p. 44-49; www.Icc.gatech.edu/ xinwei/classes/lcc/6310_ExpressiveMedium/ readings/Lynn/LynnProbableGeometries.pdf. [theoretico-philosoph. views on geometry \& shape measurement, re architecture but describes stereological 'random section model' (Buffon-DelesseRosiwal-Glagolev area sampling)]

Lyon, J.G., ed., 2002, in-press?, GIS for Watershed and Water Resource Management: New York, Taylor and Francis, 220 p. $\quad$ [publication much-delayed; at least 6 papers on DEM-based landscape analysis]

Lythe, M.B., Vaughn, D.G., and the BEDMAP Consortium, 2001, BEDMAP-a new ice thickness and subglacial topographic model of Antarctica: Journal of Geophysical Research, v. 104, no. B6, p. 11,335-11,351. [50 yrs worth of data compile new 5-km DEMs; images \& ice thickness freq.]

M

Macar, Paul, 1957-58, Compte rendu de la session extraordinaire de la Société Géologique de Belgique (in French): v. 81, p. 8-13. [more alt.-freq. using only geomorph. signif. 'bench' elevs. from large-scale maps]

Macar, Paul, 1963, Etudes récentes sur les pentes et l'évolution des versants en Belgique: Nachr. Akad. d. Wiss. Göttingen, Math. Phys. Klasse, p. 71-84. [slope-profile analysis from large-scale maps]

Macar, Paul, and Pissart, A., 1966, Recherches sur l'evolution des versants effectuées a l'Université de Liege (in French), p. 278-288 in Earth and Moon, studies presented in homage to Professor J.P. Bakker on the occasion of his sixtieth birthday: Leiden, E.J. Brill, 324 p. [summarizes methods \& results of post-WWII Belgian school of morphometry]

MacGregor, D.R., 1957, Some observations on the geographical significance of slopes: Geography, v. 42 , p. 167-173. [links 7 intervals of slope to perceptual cues \& observer position] 
MacGregor, K.R., Anderson, R.S., Anderson, S.P., and Waddington, E.D., 2000, Numerical simulations of glacial-valley longitudinal profile evolution: Geology, v. 28, no. 11, p. 1031-1034. [derive plots of elev.-distance \& valley hang \& step height]

MacLennan, M.A., Fotheringham, Stewart, Batty, Michael, and Longley, P.A., 1991, Fractal geometry and spatial phenomena-a bibliography: Santa Barbara, CA, National Center for Geographic Information and Analysis, Report 91-1, 53 p.;

http://www.ncgia.ucsb.edu/Publications/Tech_Reports/91/91-1.pdf. [excellent through 1990]

MacMillan, R.A., 2000, A protocol for preparing digital elevation (DEM) data for input and analysis using the landform segmentation model (LSM) programs: prepared for the Soil Variability Analysis to Enhance Crop Production (SVAECP) Project, prepared by LandMapper Environmental Solutions, Edmonton, AB. <http://www.infoharvest.ca/SVAECP/docs/DEM_Protocol3.pdf>. [segmentation of land-surface form fr DEM derivatives]

MacMillan, R.A., and Pettapiece, W.W., 1997, Soil landscape models-automated landform characterization and generation of soil-landscape models: Lethbridge, AB, Research Branch, Agriculture and Agri-Food Canada, Technical Bulletin no. 1997-1E. 75 p. [segmentation of landsurface form fr DEM derivatives]

MacMillan, R.A., and Pettapiece, W.W., 2000, Landform segmentation model (LSM) users manual, in Coen, G.M., Pettapiece, W.W., Goddard, T.W., Nolan, S.C., and MacMillan, R.A., eds., Landscape analysis for precision agriculture and model application: Lethbridge, $A B$, Lethbridge Research Centre, Agriculture and Agri-Food Canada, Final (internal) report, p. 8-46. [segmentation of landsurface form fr DEM derivatives]

MacMillan, R.A., Pettapiece, W.W., Nolan, S.C., and Goddard, T.W., 2000, A generic procedure for automatically segmenting landforms into landform elements using DEMs, heuristic rules and fuzzy logic, in D. Dubois, D., and Prade, H., eds., Uncertainty in Geographic Information Systems and Spatial Data: Fuzzy Sets and Systems, v. 113, no. 1, p. 81-109. [segmentation of land-surface form fr DEM derivatives]

Machín, J., and Navas, A., 1998, Spatial analysis of gypsiferous soils in the Zaragoza province (Spain), using GIS as an aid to conservation: Geoderma, v. 87, nos. 1-2, p. 57-66. [elev \& slope from $1 / 200,000$-scale DEM]

Mackay, J.R., 1954, Arithmetic-square root graph paper: The Professional Geographer, v. 6, no. 1, p. 15-16. [one way to speed up the graphing of ground slope and area curves]

Mackey, B.G., Widdifield, C.A., McKenney, D.W., Lawrence, K.M., Szcyrek, N., and Sims, R.A., 1994, Development of a new digital elevation model for Ontario, in Lee, Y. C. (chairperson), Canadian conference on GIS / Conference Canadienne sur les SIG, Ottawa, 6-10 June, Proceedings: p. 633-645. [see 1994 report]

Mackey, B.G., McKenney, D.W., Widdifield, C.A., Sims, R.A., Lawrence, K.M., and Szcyrek, N., 1994, A new digital elevation model of Ontario: Sault Ste Marie, Ontario, Natural Resources of Canada and Canadian Forest Service-Ontario NODA/NFP Technical Report No. 6, 26 p. + appendices. [200 m DEM; ANUDEM unsuccessful in low relief areas on 100m grid ; got network fr interpreted base data to enhance ANUDEM]

MacLeod, Norman, 1999, Generalizing and extending the eigenshape method of shape visualization and analysis: Paleobiology, v. 25, no. 1, p. 107-138. [a special case of 'relative warp analysis (Bookstein 1991) defined over broad variety of phenomena \& representational strategies; advocates combining 'landmark' with 'outline' techniques; MAC \& Wintel software download at http://life.bio.sunysb.edu/morph/] 
MacLeod, Norman, 2002, Geometric morphometrics and geological shape-classification systems: Earth-Science Reviews, v. 59, nos. 1-4, p. 27-47. [reviews \& discusses new 'conceptual synthesis'; distinguishes 'geometry', 'pattern recognition', \& 'morphometrics' approaches; re-do of sed. grain, leaf, \& valley shape classifications by eigenshape analysis of 'landmarks'; 8 alpine-valley cross-sections ('V' vs. 'U') fr R.J. Small 1972 geomorph. text]

Madej, M.A., 2001, Development of channel organization and roughness following sediment pulses in single-thread, gravel bed rivers Water Resources Research, v. 37, no. 8, p. 2259-2272. [step spacing \& A/channel slope; autocorrel.; thalweg-profile analysis]

Maerz, N.H., Chepur, Poornima, Myers, J.J., and Linz, Justin, 2001, Concrete roughness characterization using laser profilometry for fiber-reinforced polymer sheet application: National Research Council, Washington D.C., Transportation Research Record, no. 1775, p. 132-139; http://www.utc.umr.edu/Publications/Proceedings/2001/TRBconc.pdf. ['laser striping', adapt. of 'shadow profilometry' devel. fr. princ. of the Schmaltz microscope; 3 roughness params. (all same?, i.e., slope); reveals inconsistency in 1 of 9 CSP standard surfaces]

Maerz, N.H., and Franklin, J.A., 1990, Roughness scale effect and fractal dimension, in Pinta da Cunha, A., International Workshop on Scale Effects in Rock Masses, 1st, Loen, Norway June 4-6, Proceedings: Rotterdam, Balkema, p. 121-126. [shadow profilometry after Schmalz 1936; rockjoint surfaces not self-similar]

Magdalene, Suzanne, and Alexander, E.C. Jr., 1995, Sinkhole distribution in Winona County, Minnesota, revisited, in Beck, B.F., ed., Karst Geohazards: Rotterdam, Balkema, p. 43-51. [n=605; nearest-neighbor analysis: clustered distr.]

Mainar, C.V., 2000, Images virtuelles du relief-rupture ou continuité dans les representations du relief? (in French): Zeitschrift für Geomorphologie, v. 44, no. 2, p. 165-174. [some thoughts on evolution of relief portrayal]

Maître, Henri, and Pinciroli, Matteo, 1999, Fractal characterization of a hydrological basin using SAR satellite images: IEEE Transactions on Geoscience and Remote Sensing, v. 37, no. 1, p. 175-181. [D fr. image proc.; agree w/ Horton, Strahler, Shreve models]

Majdanowski, Stefan, 1947, Distribution, density and directions of lake-channels of the Polish lowlands (in Polish with long English summary: Przeglad Geograficzny (Polish Geographical Review), v. 21, nos. 1-2, p. 47-69. [300 100K maps sampled w/ squares; 7 map intervals; density $>$ to E.]

Makkaveev, N.I., 1955, Ruslo reki i eroziya v ee basseine (in Russian): Inst. Geogr., AN SSSR, p. 5456. $\quad\left[L=c A^{n}\right.$, where $A=$ drainage area \& $L=$ length of trunk stream; 'Hack's Law']

Malamud, B.D., and Turcotte, D.L., 2001, Wavelet analyses of Mars polar topography: Journal of Geophysical Research, v. 106, no. E8, p. 17,497-17,504. [power-law dependence of WT variance on wavelength, $b \approx 3.5-3.7]$

Maling, D.H., 1955, The geomorphology of the Wear Valley: Durham, UK, University of Durham, Ph.D. thesis, paging unknown. [5000 grid squares minimum req. for stat. signif. sample of topography]

Malthe-Sørenssen, Anders, Walmann, Thomas, Jamtveit, Bjørn, Feder, Jens, and Jøssang, Torstein, 1999, Simulation and characterization of fracture patterns in glaciers: Journal of Geophysical Research, v. 104 , no. B10, p. 23,157-23,174. [simple model of scaling relation for circumferential pattern on Iceland cauldron]

Malzbender, Thomas, Gelb, Daniel, and Wolters, Hans, 2001, Polynomial texture maps, in SIGGRAPH 2001, Los Angeles, CA, 12-17 August, Proceedings: p. 519-528; http://www1.acm.org/pubs/articles/proceedings/graph/383259/p519-malzbender/p519- 
malzbender.pdf. [enhances photorealism by storing coefficients of biquadratic polynomial in each texel (texture cell); uses images not DEMs]

Malyavsky, B.K., and Zharnovsky, A.A., 1974, On digital terrain modelling (in Russian): Geodesiya i Cartographiya, no. 6, p. 31-38. [no info]

Mandelbrot, B.B., 1985, Self-affine fractals and fractal dimension: Physica Scripta (Sweden), v. 32, no. 4, p. 257-260. [suggests relief profiles are not self-similar, \& D of non-fractal objects can be calculated, but it has no theoretical meaning]

Mandelbrot, B.B., 2002, Gaussian Self-Affinity and Fractals-globality, the Earth, 1/F noise, and R/S—selecta (old or new) vol. H: New York, Springer, 663 p. [selected works, reprinted, transl. or new w annotations \& guest contrib.]

Mangold, N., and Allemand, P., 2001, Topographic analysis of features related to ice on Mars: Geophysical Research Letters, v. 28 , no. 3, p. 407-410. [topographic profiles, topo. params of debris aprons \& scarps]

Manning, G., Fuller, L.G., Eilers, R.G., and Florinsky, I.V., 2001, Topographic influence on the variability of soil properties within an undulating Manitoba landscape: Canadian Journal of Soil Science, v. 81, no. 4, p. 439-447. [apply terrain-segmentation (by R, plan/profile curv., slope, catchment) to get 'landform element complexes']

Mansikkaniemi, Hannu, 1970, The sinuosity of rivers in northern Finland: Publicationes Instituti Geographici Universitatis Turkuensis, v. 52, p. 16-32. [new method for degree \& quality of sinuosity]

Mansikkaniemi, Hannu, 1972, Regional differences in the sinuosity of rivers in Finland: Fennia, v. 118, p. 1-33. [method. critique; applies new index to 81 rivers; 5 gen'l. types]

Margot, J.-L.C., Campbell, D.B., Jurgens, R.F., and Slade, M.A., 1999, The topography of Tycho crater: Journal of Geophysical Research, v. 104, no. E5, p. 11,875-11,882. [200-m XY/30-m Z res. from radar interferometry; crater dimensions unchanged]

Margot, J.-L.C., Campbell, D.B., Jurgens, R.F., and Slade, M.A., 1999, Topography of the lunar poles from radar interferometry-a survey of cold trap locations: Science, v. 284, no. 5420, p. 1658-1660. [150-m XY/50-m Z res. of hard-to-see terrain]

Mark, D.M., 1997, The history of geographic information systems-invention and re-Invention of triangulated irregular networks (TINS): GIS/LIS'97, Cincinnati, OH, October 28-30, Proceedings: CD-ROM, p. 267-272. ['multiple invention'; precusors (Hormann \&), T. Poiker, ADAPT, \& C. Gold]

Mark, D.M., and Smith, Barry, 2002?, A science of topography-bridging the qualitative-quantitative divide, in Shroder, J.F. Jr., and Bishop, M.P., eds., Geographic Information Science (GIScience) and Mountain Geomorphology: Chichester UK, Praxis Scientific Publishing / Springer-Verlag, in press. <http://wings.buffalo.edu/philosophy/faculty/smith/articles/topography.pdf>. [some basic underpinnings for morphometry; defining mountains \& topo. in the geospatial domain; J.J. Gibson concepts]

Mark, D.M., and Smith, Barry, 2002?, Do mountains exist? Ontology of landforms and topography: Environment \& Planning $B$, in-press.

<http://wings.buffalo.edu/philosophy/faculty/smith/articles/Mountains.htm>. [more theoretical background for morphometry; defining mtns. \& topo. in geospatial domain'; Gibsonian concepts elaborated] 
Marks, Kate, and Bates, Paul, 2000, Integration of high-resolution topographic data with floodplain flow models: Hydrological Processes, v. 14, nos. 11-12, p. 2109-2122. [high accuracy of LIDAR data needed to get good flood-hazard model]

Martinoni, Daria, and Bernhard, Luzi, 1998, A conceptual framework for reliable digital terrain modelling, in Spatial Data Handling '98 Conference, 11-15 July, Vancouver, BC, Proceedings: p. 737-750. [approach to DEM error evaluation \& prevention]

Martinoni, Daria, and Schneider, Bernhard, 1999, Pluggable terrain module-moving digital terrain modelling to a distributed geoprocessing environment, in Vckovski, A., Brassel, K.E., and Schek, H.-J., eds., INTEROP 1999, Interoperating Geographic Information Systems, 2nd, Zürich, Proceedings: Lecture Notes in Computer Science 1580, Springer, Heidelberg \& Berlin, p. 315-327. [programming software architecture]

Martz, L.W., and Garbrecht, Jurgen, 1999, An outlet breaching algorithm for the treatment of closed depressions in a raster DEM: Computers and Geosciences, v. 25, no. 7, p. 835-844. [alternative to filling pits; assumes DEM error is over-, not underestimation]

Mason, D.C., Davenport, I.J., Flather, R.A., and Gurney, C., 1998, A digital elevation model of the inter-tidal areas of the Wash, England, produced by the waterline method: International Journal of Remote Sensing, v. 19, no. 8, p. 1455-1460. [DEM fr. tide-surges on ERS-1 SAR images]

Mason, P.J., Rosenbaum, M.S., and Moore, J.McM., 1998, Digital image texture analysis for landslide hazard mapping, in Maund, J.G., and Eddleston, Malcolm, eds., Geohazards in Engineering Geology: London, The Geological Society, Engineering Geology Special Publication no. 15, p. 297-305. [enhance contrast, etc.; fine res. (10m or better) essential; still need DEM]

Masoud, Alaa, Masumoto, Shinji, Raghavan, Venkatesh, Kajiyama, Atsusuhi, and Shiono, Kiyoji, 2002, Landscape modeling and analysis based on digital elevation models generated from topographic maps-algorithm and appliocation on Safaga area, Red Sea coast, Egypt: Journal of Geosciences, Osaka City University, v. 45, art. 6, p. 73-87. [28.5-m-res. DEM min. discretization; curv.-based classif. into ridges, channels, \& conv., conc., \& planar slopes]

Massari, Remo, and Atkinson, P.M., 1999, Modeling susceptibility to landsliding-an approach based on individual landslide type: Transactions, Japanese Geomorphological Union, v. 20, no. 3, p. 151168. [generalized linear modeling; logistic regress.; geol., slope \& veg. dominant]

Mather, A.E., Harvey, A.M., and Stokes, M., 2000, Quantifying long-term catchment changes of alluvial fan systems: Geological Society of America Bulletin, v. 112, no. 12, p. 1825-1833. [log-log fan \& drainage area]

Matmon, A., Zilberman, E., and Enzel, Y., 2000, Determination of escarpment age using morphologic analysis - an example from the Galilee, northern Israel: Geological Society of America Bulletin, v. 112, no. 12, p. 1864-1876. [normalized distance/altitude graphs]

Mattar, K.E., Gray, A.L., Geudtner, D., and Vachon, P.W., 1999, Interferometry for DEM and terrain displacement-effects of inhomogeneous propagation: Canadian Journal of Remote Sensing, $v$. 25 , no. 1, p. 60-69. [atmospheric vagaries a problem; need multiple independent measurements]

Matui, Isamu, 1932, Statistical study of the distribution of scattered villages in two regions of the Tonami Plain, Toyama Prefecture: Japanese Journal of Geology and Geography, v. 9, p. 251-255. [1st use of the quadrat method for spatial analysis in geography?]

Maunder, C.J., 1999, An automated method for constructing contour-based digital elevation models: Water Resources Research, v. 35, no. 12, p. 3931-3940. [uses natural flow lines \& contours; no user-defined critical points] 
Maune, D.F., ed., 2001, Digital Elevation Model Technologies and Applications, the DEM Users Manual: Bethesda, MD, American Society for Photogrammetry \& Remote Sensing, 540 p.; https://eserv.asprs.org/wasprs/staticcontent/staticpages/1067.htm. [13 chapters on DEM operational issues; vert datums, accuracy stds, USGS DEM program, photogramm., IFSAR, LIDAR (incl. airborne bathymetry), SONAR, enabling tech., quality assessment]

Maxwell, J.C., 1955, The bifurcation ratio in Horton's law of stream numbers (abs.): Transactions, American Geophysical Union, v. 36, no. 3, p. 520. [modified to apply to stream segments; in plot of log str. no. \& str. order, abs. val. of antilog of slope of linear fit = bifurc. ratio]

Maxwell, J.C., 1967, Quantitative geomorphology of some mountain chaparral watersheds of southern California, in Garrison, W.L., and Marble, D.F., eds., Quantitative Geography, Part II, Physical and Cartographic Topics: Evanston, III., Northwestern University, Department of Geography, Studies in Geography no. 14, p. 108-226. [publ. of 1960 thesis; of Strahler students the most aware of European morphometry; multiple-regression analysis confirmed Hortonian 'laws' in steep semi-arid terrain]

Mayer, L., 2000, Application of digital elevation models to macroscale tectonic geomorphology, in Summerfield, M.A., ed., Geomorphology and Global Tectonics (papers from International Conference on Geomorphology 4th, Bologna, 1999): Chichester UK and New York, Wiley, paging unknown. [no info; presumably Larry Mayer, the quant. geomorphologist; see Mayer 1990 \& 1994?]

McAdoo, B.G., Pratson, L.F., and Orange, D.L., 2000, Submarine landslide geomorphology, US continental slope: Marine Geology, v. 169, nos. 1-2, p. 103-136. [15 morphometric params. for 83 slides; histograms, correlations]

McAllister, Michael, 1999, A watershed algorithm for triangulated terrains, in Canadian Conference on Computational Geometry 11th, Vancouver, BC, University of British Columbia, 15-18 August, Proceedings: p. 103-106 http://www.cs.ubc.ca/conferences/CCCG/elec_proc/fp50.pdf (8 p.). [DEM-to-watershed transformation; vector-based algorithm guarantees one polygon per basin]

McAllister, Michael, and Snoeyink, Jack, 1997, Medial axis generalisation of hydrology networks, in Auto-Carto 13, Symposium on Automated Cartography 13th, 5-10 April, Seattle WA, Proceedings: p. 164-173. [from TIN; added benefits from use to depict rivers \& lakes; similar to M\&S 2000?]

McAllister, Michael, and Snoeyink, Jack, 1999, Extracting consistent watersheds from digital river and elevation data: ASPRS Annual Conference, http://www.cs.ubc.ca/spider/snoeyink/papers/asprs99.pdf. [combine TIN \& steepest-descent flow models to identify watershed breaklines]

McAllister, Michael, and Snoeyink, Jack, 2000, Medial axis generalization of river networks: CaGIS, v. 27, no. 2, p. 129-138. [Voronoi quant.-carto. relation of medial axis to riverbank from TIN; similar to $M \& S$ 1997?]

McArthur, D.E., Fuentes, R.W., and Devarajan, Venkat, 2000, Generation of hierarchical multiresolution terrain databases using wavelet filtering: Photogrammetric Engineering and Remote Sensing, v. 66 , no. 3, p. 287-295. [scale-variant hierarchical triangulations (ca. like a quadtree)]

McBride, E.F., and Picard, M.D., 2000, Origin and development of tafoni in Tunnel Spring Tuff, Crystal Peak, Utah, USA: Earth Surface Processes and Landforms: v. 25, no. 8, p. 869-879. [height, width, depth plots fr field meas.]

McCarroll, Danny, 1992, A new instrument and techniques for the field mesurement of rock surface roughness: Zeitschrift für Geomorphologie, v. 36, no. 1, p. 69-79. [micro-roughness meter; 2 indices: slope std. dev., mean abs. diff adjacent slopes] 
McClung, D.M., 2001, Characteristics of terrain, snow supply and forest cover for avalanche initiation caused by logging: Annals of Glaciology, v. 32, p. 223-229. [probl. plot for start-zone slope; cross- \& down-slope shape; concave slopes most at risk]

McGill, G.E., 2001, The Utopia Basin revisited-regional slope and shorelines from MOLA profiles: Geophysical Research Letters, v. 28, no. 3, p. 411-414. [topographic profiles, crater size/frequency]

McNamara, J.P., Kane, D.L., and Hinzman, L.D., 1999, An analysis of an Arctic channel network using a digital elevation model: Geomorphology, v. 29, nos. 3-4, p. 339-353. [scaling char. hold only for channels larger than permafrost 'water tracks'; 10-m DEM]

Medler, M.J., and Yool, S.R., 1998, Computer-assisted terrain stratification: Physical Geography, v. 19 , no. 5, p. 433-443. [Terrain 'poses' (types?) from combo of elev, slope \& aspect by RGB Dig. IP]

Meentemeyer, R.K., and Moody, Aaron, 2000, Automated mapping of conformity between topographic and geological features: Computers and Geosciences, v. 26, no. 7, p. 815-829. [fr DEM \& geologic map; needs slope, aspect, \& bedding dip \& azimuth]

Mehrotra, G.S., Dharmaraju, R., and Prakash, S., 1994, Morphometric appraisal of slope instability of Chilla Landslide, Garhwal Himalaya: Journal of the Geological Society of India, v. 44, no. 2, p. 203211. [profile analysis of 1 landslide, after Crozier, 1973, suggests processes]

Mehrotra, G.S., Sakart, S., and Dharmaraju, R., 1992, Landslide hazard assessment in RishikeshTehri area, Garwal Himalaya, India, in Bell, D.H., ed., Landslides, International Symposium 6th, 1014 February, Christchurch NZ, Proceedings: Rotterdam, Balkema, v. 2, p. 1001-1006. [no DEM; slope segments; variables include drainage density, spatial freq. by slope angle \& lithology]

Meinardus, Wilhelm, 1926, Die hypsographischen Kurven Grönlands und der Antarktis und die Normalform der Inlandeisoberfläche (in German): Petermanns Geographische Mitteilungen, v. 72, no. 5/6, p. 97-105. [gross morphometry of Earth's two largest areas of continental ice]

Meisel, J.E., and Turner, M.G., 1998, Scale detection in real and artificial landscapes using semivariance analysis: Landscape Ecology, v. 13, no. 6, p. 347-362. [elev., aspect, \& slope; elk foraging in Yellowstone Park]

Mekhbaliyev, M.M., 2001, Morfometricheskiy analiz kart ekspozitsii sklonov kartografomatematicheskim metodom (in Russian; morphometric analysis of slope exposure maps by cartographic-mathematical method): Izvestiya Russkogo Geograficheskogo Obshchestva, v. 133, no. 5, p. 54-64. [relief, slope, variance analysis]

Melton, M.A., 1960, Intravalley variation in slope angles related to microclimate and erosional environment: Geological Society of America Bulletin, v. 71 , no. 2, p. $133-144 . \quad\left[4.42^{\circ} \mathrm{N}-\mathrm{S}\right.$ diff. in Wyoming ascribed solely to aysmmetric stream corrasion]

Melton, M.A., 1965, The geomorphic and paleoclimatic significance of alluvial deposits in southern Arizona: Journal of Geology, v. 73, no. 1, p. 1-38. [alluvial fan slope related to basin relief \& area]

Mendicino, Giuseppe, 1999, Sensitivity analysis on GIS procedures for the estimate of soil erosion risk: Natural Hazards, v. 20, nos. 2-3, p. 231-253. [2-D DEMON best of 3 models at getting stream flowpaths fr DEM]

Menduni, Giovanni, and Riboni, Vittoria, 2000, A physically based catchment partitioning method for hydrological analysis: Hydrological Processes, v. 14, nos. 11-12, p. 1943-1962. [new contour lineto-watershed algorithm, superior to DEM \& TIN models] 
Mertes, L.A.K., Dunne, Thomas, and Martinelli, L.A., 1996, Channel-floodplain geomorphology along the Solimões-Amazon River, Brazil: Geological Society of America Bulletin, v. 108, no. 9, p. 10891107. [downstream distance vs. sinuosity, width, bank height, \& island \& lake density, area, circularity]

Mesa, O.J., 1986, Analysis of channel networks parameterized by elevation: University of Mississippi, unpublished Ph.D. thesis, 155 p. $\quad$ [Markov analysis; width fcn. needs only 2 parameters, area \& branching]

Messina, Paula, and Stoffer, Phil, 2000, Terrain analysis of the Racetrack Basin and the sliding rocks of Death Valley: Geomorphology, v. 35, nos. 3-4, p. 253-265. [tested airflow char. fr DEM aspect $\&$ intervisibility of surrounding relief]

Meyer, Fernand, 1991, Un algorithme optimal de ligne de partage des eaux (in French): 8ème Congrès RFIA, Lyon, France, p. 847-857. [most efficient algorithm for grey scale-to-'watershed' transformation for image segmentation]

Meyer, T.H., Eriksson, Marian, and Maggio, R.C., 1997, A preliminary study on approximating hillslope at a point, in Applied Geography Conferences, Albuquerque NM, Papers and Proceedings: v. 20,

p. 177-187. [extended method of Philip \& Watson 1986 to approx. terrain surface-normal vectors]

Meyer, T.H., Eriksson, Marian, and Maggio, R.C., 2001, Gradient estimation from irregularly spaced data sets: Mathematical Geology, v. 33, no. 6, p. 693-717. [a generalization of finite-difference methods; uses directional derivatives; see M.E.M. 1997]

Midtbø, Terje, 1987, Digitale terrengmodellar: University of Trondheim, Norwegian Institute of Technology, Department of Surveying and Mapping, unpublished Master's thesis, paging unknown. [no info]

Mikhail, E.M., Bethel, J.S., and McGlone, J.C., 2001, Digital elevation models (DEMs), §8.2.1 in Introduction to Modern Photogrammetry: New York, Wiley, p. 228-233. [explains grid vs. TIN, var. caveats, banding in raster DEMs]

Miklós, Ladislav, 1991a, Morphometric indices of the relief in the LANDEP methods and their interpretation: Ecology (CSFR), v. 10, no. 2, p. 159-186. [drainage-basin parameters]

Miklós, Ladislav, 1991b, Interpretation of the morphometric relief indices for spatial differentiation of microclimatic conditions: Ecology (CSFR), v. 10, no. 2, p. 223-246. [no info; probl. drainage-basin parameters]

Milana, J.P., and Ruzycki, Lucía, 1999, Alluvial-fan slope as a function of sediment transport efficiency: Journal of Sedimentary Research, v. 69 , no. 3, p. 553-562. [n=37; power laws: fan \& basin $A$; precip = major var. in fan-to-fan slope diffs.]

Miliaresis, G.Ch., 1999, A region growing algorithm for the segmentation of alluvial fans from digital elevation models, in Symposium on Imaging Applications in Geology, Geovision99, University of Liège, Belgium, May 6-7, Proceedings: p. 189-192. [Old Army 3' DEM; Death Valley; complex procedure, req. Landsat image]

Miliaresis, G.Ch., 1999, Automated segmentation of alluvial fans to regions of high to intermediate flood hazard from Landsat Thematic Mapper imagery, in International Symposium on Operationalization of Remote Sensing, 2nd, ITC Enschede, Neth., August 16-20, Proceedings: CDROM; abstract = http://www.itc.nl/ags. [Old Army 3' DEM; Death Valley; complex procedure (region-growing), req. Landsat image]

Miliaresis, G.Ch., 2000, Recognition of landforms from DEMs and satellite imagery with expert systems, pattern recognition and image processing techniques (in Greek with English abstract \& 
reference list): National Technical University of Athens, Dept. of Surveying and Regional Planning, unpublished Ph.D. thesis, 267 p. [Zagros \& Great Basin mtns. fr GTOPO30, their extraction, parametric repr., fuzzy repr. \& pattern recognition]

Miliaresis, G.Ch., 2001a, Geomorphometric mapping of Zagros Ranges at regional scale: Computers and Geosciences, v. 27, no. 7, p. 775-786. [mountains delimited by region-growing algorithm]

Miliaresis, G.Ch., 2001b, Extraction of bajadas from digital elevation models and satellite imagery: Computers and Geosciences, v. 27, no. 10, p. 1157-1167. [bajadas delimited by slope \& drainage pixels in region-growing algorithm]

Miliaresis, G.Ch., and Argialas, D.P., 1998, Parametric representation and classification of mountain objects extracted from moderate resolution digital elevation data, in Buccianti, A., Nardi, G., and Potenza, R., eds., Annual Conference 4th, International Association for Mathematical Geology, Isola d'Ischia, Naples, IT, October 5-9, Proceedings: p. 892-897. [12 params. \& 36 Nevada mountain ranges fr. GTOPO30]

Miliaresis, G.Ch., and Argialas, D.P., 1998, Physiographic feature extraction from moderate resolution digital elevation data, in Annual Conference 24th, RSS98, Remote Sensing Society, University of Greenwich, UK September 9-11, Proceedings: p. 545-551. [GTOPO30 work; precursor to 1999 C\&G paper]

Miliaresis, G.Ch. and Argialas, D.P., 1999a, Fuzzy pattern recognition of compressional mountain ranges in Iran, in Annual Conference 5th, International Association for Mathematical Geology, Trondheim, August 6-11, Proceedings: p. 227-232. [region-growing fr. ridge \& valley seed pixels? same 6 parameters as Basin \& Range]

Miliaresis, G.Ch., and Argialas, D.P., 1999b, Formalisation of the photo-interpretation process by a fuzzy set representation of mountain objects in the geomorphic context of the Great Basin Section, in Annual Conference 25th, RSS99, Remote Sensing Society, University of Wales, Cardiff, UK, September 8-10, Proceedings: p. 745-750. [GTOPO30; attributes: diam., eccentricity, elev., relief, massiveness, slope]

Miliaresis, G.Ch., and Argialas, D.P., 1999c, Segmentation of physiographic features from the global digital elevation model / GTOPO30: Computers and Geosciences, v. 25, no. 7, p. 715-728. [US Basin \& Range mtns., basins, \& piedmont slopes: region-growing fr. ridge \& valley seed pixels]

Miliaresis, G.Ch., and Argialas, D.P., 2000, Extraction and delineation of alluvial fans from digital elevation models and Landsat thematic map images: Photogrammetric Engineering and Remote Sensing, v. 66, no. 9, p. 1093-1101. [Old Army 3' DEM; Death Valley; complex procedure (regiongrowing), req. Landsat image]

Miliaresis, G.Ch., and Argialas, D.P., 2002, Quantitative representation of mountain objects extracted from the global digital elevation model (GTOPO30): International Journal of Remote Sensing, v. 23, no. 5, p. 949-964. [12 mtn. params. classif. by K-means into 4 spatially distinct mtn. clusters]

Miller, D.J., 1995, Coupling GIS with physical models to assess deep-seated landslide hazards: Environmental and Engineering Geoscience, v. 1, no, 3, p. 263-276. [factor-of-safety modeled for 12,438 30-m DEM topo profiles]

Miller, J.P., 1958, High mountain streams-effects of geology on channel characteristics and bed material: Socorro NM, State Bureau of Mines and Mineral Resources, Memoir 4, 53 p. [Hack's law \& other quant. relations verified in Sange de Cristo Range]

Miller, J.P., and Leopold, L.B., 1963, Simple measurements of morphological changes in river channels and hill slopes, in Changes of Climate, Arid Zone Research 20, Rome Symposium, Proceedings: Paris, UNESCO, p. 421-427. [no info] 
Miller, J.W., 1972, Variations in New York drumlins: Annals of the Association of American Geographers, v. 62 , no. 3, p. 418-423. [length, width, height fr. $1 / 24 \mathrm{~K}$ contour maps]

Miller, O.M., 1951, Relief on maps and models-some conclusions and a proposal: Columbus OH, Ohio State University, Mapping and Charting Research Laboratory, Technical Paper no. 151. [the slope-zone technique of Miller \& Summerson 1960]

Milling, M.E., and Tuttle, S.D., 1964, Morphometric study of two drainage basins near lowa City, lowa: lowa Academy of sciences Proclamations, v. 71, p. 304-319. [azimuthal asymmetry explained by differential deposition of loess]

Milne, B.T., 1991, Lessons from applying fractal models to landscape patterns, in Turner, M.G., and Gardner, R.H., eds., Quantitative Methods in Landscape Ecology, the analysis and interpretation of landscape heterogeneity: New York, Springer-Verlag, Ecological Studies Series, p. 199-235. [quantifying the non-topo $X, Y$ domain]

Milne, J.A., and Sear, D.A., 1997, Modelling river channel topography using GIS: International Journal of Geographical Information Science, v. 11, no. 5, p. 499-519. [Contains summary of DEM applications]

Milton, L.E., 1967, Analysis of the laws of drainage-net composition: Bulletin of the International Association for Scientific Hydrology, v. 12, no. 1, p. 51-56. ['laws' are stat. prob. functions resulting from the technique itself]

Mino, Yokichi, 1942, Study on peneplains viewed from rock floor theory (Chikei Genron; in Japanese): Kokon-shoin, Tokyo, p. 393-408. [unspecified geomorphometry]

Mino, Yokichi, 1981, Early episode of quantitative research on landform evolution (in Japanese with English abstract): Transactions, Japanese Geomorphological Union, v. 2, no. 1, p. 135-137. [brief review of $\geq$ '40's Japanese morphometry]

Mironova, E.A., 1958, Experiment in morphometric description of erosion relief, in Rihter, G.D., and Dyachenko, A.E., eds., Agricultural Erosion and Its Control: Soviet Academic Press, Moscow, p. 193-222. [no info]

Mitásová, Helena, 1993, Surfaces and Modeling: GRASSclippings (Champaign, III., U.S. Army Corps of Engineers, Construction Engineering Research Laboratory), V. 7, no. 1, p. 18-19. [slope curves (flowlines), raster maps of flowpath length \& flowline densities fr raster DEM]

Mitchell, N.C., 2001, Transition from circular to stellate forms of submarine volcanoes: Journal of Geophysical Research, v. 106, no. B2, p. 1987-2003. [n=141; elongation, moment of inertia, perimeter dist.; trans. ca. $3 \mathrm{~km}$ edifice height]

Mizukoshi, Hiroko, and Aniya, Masamu, 2000, Automated classification of plan and profile forms of slope using digitized contour data (in Japanese with English abstract \& figure captions): Transactions, Japanese Geomorphological Union, v. 21, no., 3, p. 307-328. [Contour-to- (1) convergent, divergent \& planar slopes, \& (2) concave, convex \& planar profiles]

Mizukoshi, Hiroko, and Aniya, Masamu, 2002, Use of contour-based DEMs for deriving and mapping topographic attributes: Photogrammetric Engineering and Remote Sensing, v. 68, no. 1, p. 83-93. [algorithms generate flow (fall) lines and then compute slope gradient \& aspect \& classify \& map slope profile \& plan forms]

Moellering, Harold, 2001, Analytical cartography-past, present, and future, in AGILE Conference on Geographic Information Science, 4th, GI in Europe-Integrative, Interoperable, Interactive, Brno, Czech republic, 19-21 April, Proceedings: p. 599-614; 
http://agile.isegi.unl.pt/Conference/Brno2001/Questions.pdf. [review briefly mentions fractals, TIN, Warntz nets; biblio]

Molchanov, A.K., 1967, On the study of characteristic and limiting slope angles in the southern regions of the Buryat A.S.S.R. (in Russian): Metody Geomorfologicheskikh Issledovannii, no. 1, p. 134-143. [1 $1^{\circ}, 3^{\circ}-4,9-12,16-18,31-33^{\circ}$; gentle slopes more common than level land]

Monmonier, M.S., Pfaltz, J.L., and Rosenfeld, Azriel, 1966, Surface area from contour maps: Photogrammetric Engineering and Remote Sensing, v. 32, no. 3, p. 476-482. [processes digitized contours; Surface area related to projected area]

Montgomery, D.R., 1998, Review of 'Fractal River Basins. Chance and Self-Organization' by Ignacio Rodríguez-Iturbe and Andrea Rinaldo: Nature, v. 396, no. 6711, p. $536 . \quad$ ['stimulating, etc.'; reviewer defends 'reductionist, process-oriented' work decried by authors]

Montgomery, D.R., 2000, Erosional processes at an abrupt channel head-implications for channel entrenchment and discontinuous gully formation, in Darby, S.E., and Simon, Andrew, eds., Incised River Channels_-Processes, Forms, Engineering and Management: Chichester UK, John Wiley \& Sons, p. 247-276. [inverse relation betw. drainage area and slope for the Marin Co. CA test site]

Montgomery, D.R., 2001, Slope distributions, threshold hillslopes, and steady-state topography, in Pazzaglia, F.J., and Knuepfer, P.L.K., eds., The steady-state orogen-concepts, field observations, and models: American Journal of Science, v. 302, nos. 4 \& 5, p. 432-454. [DEMs of Olympic \& Oregon Coast Range Mts. test relations among SD, TH, \& SST]

Montgomery, D.R., Balco, Greg, and Willet, S.D., 2001, Climate, tectonics, and the morphology of the Andes: Geology, v. 29, no. 7, p. 579-582. [broad-scale orometry; cross-range asymmetry, width, hypsometry, \& max. elev.]

Montgomery, D.R., and Brandon, M.T., 2002, Topographic controls on erosion rates in tectonically active mountain ranges: Earth and Planetary Science Letters, v. 201, no. 3-4, p. 481-489. [slope \& relief; nonlinear rate w/ relief; GTOPO30 local relief on $10 \mathrm{~km}$ circles for 4 continents]

Montgomery, D.R., and Dietrich, W.E., 1994, A physically based model for the topographic control on shallow landsliding: Water Resources Research, v. 30, no. 4, p. 1153-1171.

$\mathrm{http}: / /$ socrates.berkeley.edu/ geomorph/shalstab/. [development of software to predict debris flow]

Montgomery, D.R., and Greenberg, H.M., 2000, Local relief and the height of Mount Olympus: Earth Surface Processes and Landforms, v. 25, no. 4, p. 385-396. [valley W/slope L \& \% local relief (30-m DEM) infer eros. control of high peak location]

Moore, I.D., Burch, G.J., and Mackenzie, D.H., 1988, Topographic effects on the distribution of surface soil water and the location of ephemeral gullies: Transactions, American Society of Agricultural Engineers, v. 31, no. 4, p. 1098-1107. [topo. heterogeneity vital in pred. catchment moisture; TOPO software for terrain analysis formally became TAPES]

Moores, E.A., 1966, Regional drainage basin morphometry: lowa State University, Ames, IA, unpublished Ph.D. dissertation, paging unknown. [Drainage basin morphometry, fluvial features]

Mora C., Sergio, and Vahrson, W.-G., 1994, Macrozonation methodology for landslide hazard determination: Bulletin of the Association of Engineering Geologists, v. 31, no. 1, p, 49-58. [unusual in that uses relative relief on $1 \mathrm{~km}$ as slope parameter]

Morawetz, Sieghard, 1937, Das Problem der Taldichte und Hangzerschneidung (in German; The problem of valley density and slope incision): Petermanns Geographische Mitteilungen, v. 83, no. 12, p. 346-350. [comparative drainage density (12 refs.) \& geomorphic process] 
Morawetz, Sieghard, 1939, Reliefenergie und Vergletscherung in der Nanga Parbat-Gruppe: Zeitschrift für Gletscherkunde, v. 26, no. 3-4, p. 303-307. [no info]

Morawetz, Sieghard, 1957, Fragen der Talnetz- und Kammentwicklung insbesondere in den Ostalpen und einigen Nachbargebieten (in German; ... on valley network \& ridge development esp. in eastern Alps \& contiguous areas), in Neef, Ernst, ed., Geomorphologische Studien (the Machatschek Festschrift): Gotha, VEB Hermann Haack, Ergänzungsheft (supplement volume) no. 262 to Petermanns Geographischen Mitteilungen, p. 91-101. [drainage density (same 12 Flußdichte refs as 1937 paper) \& geomorphic process]

Morgen, Herbert, 1940, Die natürlichen Ertragsfaktoren ... in 26 Landkreisen Pommerns. Ein raumpolitische Studie (in German; natural yield factors ... in 26 Pomeranian districts. A geo-political study): Berichte über Landwirtschaft, N.F., no. 151, p. $28 . \quad$ [map of relative relief; 1/850K; 8 intervals]

Morisawa, M.E., 1959a, Relation of morphometric properties to runoff in the Little Mill Creek, Ohio, drainage basin: Office of Naval Research Project NR 389-042, Contract N6 ONR 271-30: Nonr 266 (50), Technical Report no. 17: New York, Columbia University, Department of Geology, 10 p. [prelude to thesis; signif. power-fcn. correl. for stream L, relief ratio, \& 2 shape ratios]

Morisawa, M.E., 1959b, Relation of quantitative geomorphology to stream flow in representative watersheds of the Appalachian Plateau province: Office of Naval Research Project NR 389-042, Contract N6 ONR 271-30: Nonr 266 (50), Technical Report no. 20: New York, Columbia University, Department of Geology, 94 p. $\quad$ [published in 1962; identified 5 diff. types of difficulty in defining channel networks fr contour maps]

Mosley, M.P., and Parker, R.S., 1973, Re-evaluation of the relationship of master streams and drainage basins-discussion: Geological Society of America Bulletin, v. 84, no. 9, p. 3123-3125. [var. criticisms of Mueller 1972 on Hack's law exponent]

Mossman, James, 2001, New color system enhances relief mapping: ArcUser (ESRI, Redlands CA), Jan.-March, p. 54-56. [continuous-appearing shaded-relief fr lighter, closer-spaced color palette]

Mostafa, M.E., and Hussein, M.T., 1997, Automated characterization of some morphological features with application to Khor Baraka drainage basin, Sudan: Journal of King Abdulaziz University (Saudi Arabia), Earth Science, v. 9, p. 39-55, 1997. [basin perimeter, total \& fractal areas, hypsometric curves, network maps]

Mueller, J.E., 1972, Re-evaluation of the relationship of master streams and drainage basins: Geological Society of America Bulletin, v. 83, no. 11, p. 3471-3473. [Hack's law exponent $\sim 0.47$ for 65 mid-to-large basins]

Mueller, J.E., 1973, Re-evaluation of the relationship of master streams and drainage basins-reply: Geological Society of America Bulletin, v. 84, no. 9, p. 3127-3130. [Hack's law exponent $\sim 0.55$ for 250 small-to-large basins; stream sinuosity not an influence on $\sim 0.5$ exponent]

Müller, Bernd, and Mietz, Olaf, 1991, Zum Einfluß morphometrischer Faktoren auf Prozeßabläufe in Binnenseen am Beispiel von Seengruppen des Jungmoränengebietes im nördlichen Mittel- und Osteuropa (... morph. factors influencing process sequence in inland lakes ..., in German): Petermanns Geographische Mitteilungen, v. 135, no. 2, p. 123-132. [lake-basin shape, slope of floor, \& floor roughness]

Müller, Emil, 1912, Lehrbuch der Darstellenden Geometrie für Technische Hochschulen, v. I (in German; 1st publ. 1908?, v. 2 in 1916): Leipzig \& Berlin, Teubner, p. $52 . \quad$ [inspired Rothe 1915?; ascribes earliest descriptive-geometric treatment of ridges \& watercourses to Dupuis de Torcy \& Brisson 1808, but claims 'a perfectly rigorous geometrical definition ... has not yet been found'] 
Müller, Emil, 1919, Besondre Punkte und Linien auf der Geländefläche; Verlauf von Schichten- und Fallinien (in German: special points \& lines on the ground surface; course of contour and slope lines, § 166 in Lehrbuch der Darstellenden Geometrie für Technische Hochschulen, v. I (?) (2nd ed; 1st publ. 1918?): Leipzig \& Berlin, Teubner, p. 47-53. [expanded? his 1912 treatment (other earlier editions exist); refs Dupuis de Torcy \& Brisson 1808 (1st modern citation?), later French work, Maxwell 1870; credits Rothe 1915 with correctly defining watercourses]

Murata, Teizo, 1931a, Theoretical consideration on the shape of alluvial fans: Geographical Review of Japan, v. 7, no. 7, p. 569-586. [not seen; geometric conceptualization of fan relief and plan

form? as equations?]

Murata, Teizo, 1931b, Relation betwen a fan and its surrounding mountains: Geographical Review of Japan, v. 7, no. 8, p. 649-663. [not seen; geometric relations?]

Murphey, J.B., Wallace, D.E., and Lane, L.J., 1977, Geomorphic parameters predict hydrograph characteristics in the Southwest: Water Resources Bulletin, v. 13, no. 1, p. 25-38. [catchment area = best; new shape/size param.]

Murray, John, 1886, Drainage areas of the continents and their relation to oceanic deposits: Scottish Geographical Magazine, v. 2, no. 9, p. 548-555. [watershed planimetry of new Bartholomew global Lambert equal-area maps; land/water (area) $=1 / 2.5$, cf. Penck 1886]

Murtaugh, C.R., and Antonatos, P.P., 1949, Test of the 2' x 2' supersonic wind tunnel nozzle: U.S. Air Force Memorandum Report MCREXA9-90311-1-10, 1 July, paging unknown. [PSD-like surface-curvature analysis of metal-finishing, adapted by Schloss 1965 to terrain analysis for Apollo Project]

Musgrave, F.K., 1993, Methods for realistic landscape imaging: New Haven, CT, Yale University, unpublished Ph.D. dissertation, 268 p. [fractal Brownian motion simulations]

Musgrave, G.W., 1947, The quantitative evaluation of factors in water erosion, a first approximation: Journal of Soil and Water Conservation, v. 2, no. 3, p. 133-138. [derived equation for soil loss; uses data fr. uniform slopes]

Myers, D.M., 1999, Review of 'GSLIB-Geostatistical Software Library and User's Guide, second edition,' by C.V. Deutsch \& A.G. Journel, 1998: Computers and Geosciences, v. 25, no. 3, p. 309312. [thorough review; mildly critical; 'strictly user-beware;' cites other software]

\section{$\mathbf{N}$}

Naden, P.S., 1993, A routing model for continental-scale hydrology, in Symposium on Macroscale Modeling of the Hydrosphere, Yokohama, July, Proceedings: IAHS Publication 214, p. 67-79. [early broad-scale DEM-based model; implicit source-to-sink method]

Nagel, Dr., 1835, Über die Küstengestaltung der Erdteile (on the coastal shape of the continents, in German): Heinrich Berghaus' Annalen der Erd-, Völker-, und Staatenkunde (Berlin), v. 12, p. 490497. [after Ritter 1826, next work on coast shape?; $\mathrm{K}=\mathrm{U} / 2 \sqrt{\mathrm{F}} \Pi: \mathrm{U}=$ coast perimeter, $\mathrm{F}=$ area enclosed; see Rohrbach, 1890]

Nakano, M., Takagi, A., and Haraguchi, N., 1985, Stochastic simulation of gully networks on eroded land, in El-Swaify, S.A., Moldenhauer, W.C., and Lo, Andrew, eds., Soil Erosion and Conservation: Ankeny, lowa, Soil Conservation Society of America, p. 178-187. [used prior sim. models \& Strahler ordering; varied results]

Nakayama, Daichi, 1998, A study of DEM-based drainage basin classification-the case of the Abukuma Mountains (in Japanese with English abstract \& figure captions): Geographical Review of Japan, v. 71A, p. 169-186. [54 basins, 5 hyps. \& 6 planim. char.; PCA $=3$ PC's \& 4 types] 
NASA, 2002, Shuttle Radar Topography Mission: U.S. National Aeronautics and Space Administration, http://www.jpl.nasa.gov/srtm/. [official online source for SRTM data and information]

Natarajan, Padma, 1999, Intelligent retrieval of ridgelines from digital elevation models: Orono ME, University of Maine, Dept. of Electrical and Computer Engineering, unpublished MSEE thesis, paging unknown. [presented at 1999 ASPRS ANnual Conference]

Nellemann, Christian, and Reynolds, P.E., 1997, Predicting late winter distribution of muskoxen using an index of terrain ruggedness: Arctic and Alpine Research, v. 29, no. 3, p. 334-338. [Indices based on contour characteristics fr topo maps]

Neumann, G.A., Rowlands, D.D., Lemoine, F.A., Smith, D.E., and Zuber, M.T., 2001, Crossover analysis of Mars Orbiter Laser Altimeter data: Journal of Geophysical Research, v. 106, no. E10, p. 23,753-23,768. [error for 5000 orb. profiles modeled by $24 \mathrm{M}$ elev. crossovers; adjusted tracks accuracy $<1 \mathrm{~m}$ vert.]

Neumann, Ludwig, 1889, Die mittlere Kammhöhe der Berner Alpen (in German, mean crest levels of the Bernese Alps): Berichte der Naturforschenden Gesellschaft zu Freiberg im Br., v. 4, no. 1, p. 45-50. [definition of 'mean crest-level'-height 'longitudinal crest profile would take if limited to consistently even portions parallel to sea level', as cited by Fiedler 1890]

Neumann, Ludwig, 1888, Orometrische Studien im Anschluß an die Untersuchungen des Kaiserstuhlgebietes (orometric studies after investigations of the Kaiserstuhl area; in German): Zeitschrift für wissenschaftliche Geographie (Weimar), v. 7, no. 1, p. 320-332. [post-Sonklar work; cited elsewhere as 'Untersuchung' \& 'Kaiserstuhlgebirges']

Neumann, Ludwig, 1889, Orometrische Studien im Anschluß an die Untersuchungen des Kaiserstuhlgebietes (conclusion): Zeitschrift für wissenschaftliche Geographie (Weimar), v. 7, no. 2/3, p. 362 (361?)-378. [balance of Neumann 1888]

Neumann, Ludwig, 1900, Die Dichte des Flußnetzes im Schwarzwalde (Stream network density in the Black Forest, in German): Gerlands Beiträge zur Geophysik, Leipsig, v. 4, ca. p. 222. [early dd work; defined drainage density $=L / A ; L=$ total stream lengths $\& A=$ basin area; $1 \mathrm{~km}$ squares]

Newman, W.I., Turcotte, D.L., and Gabrielov, A.M., 1997, Fractal trees with side branching: Fractals, v. 5, no. 4, p. 603-614. [more direct descr. of river structure, based on Tokunaga scaling]

Newson, M.D., 1978, Drainage Basin characteristics, their selection, derivation and analysis for a flood study of the British Isles: Earth Surface Processes, v. 3, no. 3, p. 277-293. [ [>1000 basins]

Nice, Bruno, 1948, Energia del rilievo, in La fittezza del reticolato idrografico nell'Appennino toscoemiliano: Riv. Geogr. Ital., v. 60 , p. 11-22, \& 65-98. [1/700K relative-relief map; 3x3 samples; 7 intervals]

Nicholls, R.J., and Small, Christopher, 2002, Improved estimates of coastal population and exposure to hazards released: EOS, Transactions, American Geophysical Union, v. 83, no. 28, p. 301, 305. [quant. rel. (graphs \& maps) of pop. density to elev. \& distance from coast; need LiDAR to improve low-lying elevs.]

Nieuwenhuis, J.D., and van den Berg, J.A., 1971, Slope investigations in the Morvan (Haut Folin area): Revue de Géomorphologie Dynamique, v. 20, no. 4, p. 161-176. [6063 field-profile angles at $10-m$ length; stat. relation betw. slope \& elev. \& rock type]

Nikora, V.I., and Goring, D.G., 2001, Extended self-similarity in geophysical and geological applications: Mathematical Geology, v. 33, no. 3, p. 251-271. [structure func. \& ESS (extended self-sim.) plots of Martian topo. \&] 
Nogami, Michio, 1995, Geomorphometry for detailed digital elevation model (in Japanese with English summary): Chishitsu Chosajo Geppo (Bull. Japan. Geol. Survey), v. 46, no. 4, p. 465-474.

[DEM's, drainage basins \& patterns, math. models]

Nogami, Michio, 1998, An algorithm and a C-program source for automated drainage network extraction (in Japanese with English abstract): Theory and Applications of GIS (J. of GIS Assoc. of Japan), v. 6 , no. 1 , p. 95-102. [flood-type; random-walk techn. gives good results on flats]

Nogami, Michio, 1999, Effects of geology on geomorphometric characteristics analyzed by a $50-\mathrm{m}$ digital elevation model (in Japanese with English abstract and figure captions): Geographical Review of Japan, v. $72 \mathrm{~A}$, no. 1, p. 23-29. [50m DEM; height, slope, convexity, \& geology of Japan change through time]

Nogami, Michio, 2000, 50m-DEM and landforms of Japanese Islands (abs.): Transactions, Japanese Geomorphological Union, v. 21, no. 1, p. 69-70. [PCA of morphometric properties of 597 mountain summits]

Noguchi, Naohiko, 1972, Quantitative geomorphology and relative rate of erosion, Pescadero Creek Basin, San Mateo Co., California: University of Santa Cruz, Dept. Earth Sciences, unpublished M.Sc. thesis, 109 p. [only the areal params. correlate highly with environmental variables]

Nolan, T.J., Kirk, R.M., and Shulmeister, J., 1999, Beach cusp morphology on sand and mixed sand and gravel beaches, South Island, New Zealand: Marine Geology, v. 157, no. 3-4, p. 185-198. [most quant relations covary; amplitude \& spacing poorest]

Noumi, Yousuki, Shiono, Kiyoji, Masumoto, Sinji, and Raghavan, Venkatesh, 1999, Generation of DEM from the topographic maps-utilization of inter-contour information (in Japanese with English abstract \& figure captions): Geoinformatics, v. 10, no. 4, p. 235-246. [interpolates elevs. from set of inequality constraints prior to creating DEM]

Nowacki, Gregory, Shephard, Michael, Krosse, Patricia, Pawuk, William, Fisher, Gary, Baichtal, James, Brew, David, Kissinger, Everett, and Brock, Terry, 2001, Ecological subsections of Southeast Alaska and neighboring areas of Canada: USDA Forest Service, Alaska Region, Technical Publication No. R10-TP-75, 306 p. [binned elev., slope, aspect, 'roughness' (std. dev. elev.) \& slope \& elev. histograms for 73 regions fr 60m DEM (1:63,360 maps)]

Nowak, Hans, 1944, Die Reliefenergie im Grenzsaume der Böhmischen Masse zwischen Donau und Thaya: Mitteilungen Geograph. Ges. Wien, no. 87, p. 16-18. [1/420K relative-relief map; 1 km samples; 7 relief intervals]

Nuth, Van, Pulliam, Jay, and Wilson, Clark, 2002, Migration of radar altimeter waveform data: Geophysical Research Letters, v. 29 , no. 10 , p. 131-1 to 131-4. [Greenland ice-sheet data reveal one limitation of current radar altmeters]

Nye, J.F., 1965, Flow of a glacier in a channel of rectilinear, elliptic, or parabolic cross-section: Journal of Glaciology, v. 5 , no. 41 , p. 661-690. [shape factor $=(\mathrm{A} / \mathrm{h}$ of trimline above thalweg $) \times$ trough perimeter]

O'Donnell, Greg, Nijssen, Bart, and Lettenmaier, D.P., 1999, A simple algorithm for generating streamflow networks for grid-based, macroscale hydrological models: Hydrological Processes, v. 13, no. 8, p. 1269-1275. [gets coarse-scale network from fine-scale DEMs using accumulation-flow file] 
O'Sullivan, David, and Turner, Alasdair, 2001, Visibility graphs and landscape visibility analysis: International Journal of Geographical Information Science, v. 15, no. 3, p. 221-237. [applied graph theory yields pixel surface colored by size of visible neighborhoods]

Ochi, Shiro, and Shibasaki, Ryosuke, 1999, Development of $1 \mathrm{~km}$ drainage model based on GTOPO30 and global data sets, in Otsubo, Kuninori, Tsuboi, Kaoru, and Hiromoto (Airies), Misako, eds., 1999 NIES Workshop on Information Bases and Modeling for Land-use and Land-cover Changes Studies in East Asia, 25-27 January, Tsukuba, Japan, Proceedings: p. 201-205. [algorithm for drainage-direction matrix, but fit still inconsistent]

Ochi, Shiro, and Shibasaki, Ryosuke, 1999, Algorithm for generating drainage direction matrix using DEM (GTOPO30) and DCW (in Japanese with English abstract and figure captions): Journal of the Japan Society of Photogrammetry, v. 38, no. 3, p. 60-68. [combines DEM with planimetric stream depiction to get better DDM]

Ochis, Heidi, and Russell, E.C., 1997, Comparison of a piecewise transformation to polynomial-based geometric correction algorithms: Boulder, CO, Computer Terrain Mapping, Inc., 13 p.; http://www.ctmap.com/gis_journal/geotin.pdf. [piecewise technique better, \& for all relief types]

Ochis, Heidi, Russell, E.C., and Hoffer, R.M., 1997, A comparison of a triangulation-based piecewise transformation to polynomial-based geometric correction algorithms, in ACSM/ASPRS Annual Convention \& Exposition, Seattle, WA, April 7-10: Technical Papers, v. 3, p. 215-225. [piecewise technique better, \& for all relief types]

Ogden, F.L., Garbrecht, Jurgen, DeBarry, P.A., and Johnson, L.E., 2001, GIS and distributed watershed models. II-modules, interfaces, and models: Journal of Hydrologic Engineering, v. 6, no. 6, p. 515-523. [2nd of 2-part GIS tutorial for practicing engineers; applics.]

Oguchi, Takashi, Tanaka, Yukiya, Kim, Tae-Ho, and Lin, Zhou, 2001, Large-scale landforms and hillslope processes in Japan and Korea: Transactions of the Japanese Geomorphological Union, v. 22, no. 3, p. 321-336. [A/elev., slope map, slope/elev., \% slope $>15^{\circ} \& \%$ slope $<2 \%$ elev.]

Ohmori, Hiroo, and Sugai, Toshihiko, 1994, Morphometrical characteristics of landslide masses and their geomorphological implications: Transactions, Japanese Geomorphological Union, v. 15, no. 1, p. 1-16. [see 1995 paper by same authors]

Oimoen, M.J., 2000, An effective filter for removal of production artifacts in U.S. Geological Survey 7.5-minute digital elevation models, in Conference on Applied Geologic Remote Sensing, 14th, 6-8 Nov., Las Vegas, NV, Proceedings: Ann Arbor, MI, Veridian ERIM International, p. 311-319; http://edcnts12.cr.usgs.gov/ned/filter/; also http://gisdata.usgs.net/ned/filter/index.html. ['mean profile filter' at least partially successful in removing 'stripes' from level 1 USGS DEMs]

Okagama, T., 1969, Gipfelflur, in Quaternary tectonic map of Japan: National Research Center for Disaster Prevention, map no. 6, 1/2,000,000. [summit-height envelope fr 1.5' x 1.25' grid $\& 1 / 50,000$ maps]

Okayama, T., 1932, Some problems on mountain topographic features (in Japanese): Geography of Iwanamikoza (Geographical course of Iwanami), Iwanamisyoten, Tokyo, 50 p. [among earliest Japanese use of morphometric methods]

Okayama, T., 1953, The geomorphic structure of Japan-as a starting point of regional geomorphology (in Japanese): Sundai Shigaku (Sundai Historical Review), v. 13 (not 3?), p. 28-38. [summit-height envelope fr $1.5^{\prime} \times 1.25^{\prime}$ grid \&1/50,000 maps]

Okimura, Takashi, and Kawatani, T., 1986, Mapping of the potential surface-failure sites on granite mountain slopes, in Gardiner, V., ed., International Geomorphology 1986, Part I: New York, John Wiley \& Sons, p. 121-138. [debris flows; incl. slope \& slope curvature fr.10m DEM] 
Olivera, Francisco, Famiglietti, James, and Asante, Kwanbena, 2000, Global-scale flow routing using a source-to-sink algorithm: Water Resources Research, v. 36, no. 8, p. 2197-2207. [instead of cell-to-cell routing; hydrographs for large basins fr. GTOPO30 seem OK]

Olivera, Francisco, 2001, Extracting hydrologic information from spatial data for HMS modeling: Journal of Hydrologic Engineering, v. 6, no. 6, p. 524-530. [princ. \& meth. behind DEM-towatershed, etc. for input to USACE's modeling system]

Olivier, J., and Valentine, R., 1965, Engineering Lunar Model Obstacles (ELMO): JFK Space Center, Future Studies Branch, Launch Support Equipment Engineering Division, Tech. Report TR-145-D, paging unknown. [to provide pre-real lunar data quant. design criteria for Lunar Roving Vehicle design concepts; synthetic technique used 2 params, terrain obstacle spacing (constant) \& size (var.), for var. topo profiles]

Onde, H., 1938, La Maurienne et la Tarentaise, étude morphologique (in French): Revue de Géographie Alpine, v. 26?, p. 663-771; also La Maurienne et la Tarentaise. Étude de géographie physique: Thèse Lettres Grenoble / Grenoble, Arthaud, 624 p. [applic. of morphometry; correl. basin discharge w/ mean elev., etc.; esp. ch. VI, p. 75-103]

Onde, H., 1939, L'aération des massifs montagneux et son évaluation (in French): Revue de Géographie Alpine, v. 27, p. 447-453. ['coefficient of aeration' applied to mountains]

Ongley, E.D., 1968, Towards a precise definition of drainage basin axis: Australian Geographical Studies, v. 6, no. 1, p. 84-88. ['basin vectoral axis' = vector resultant of high-order links]

Ore, H.T., and White, E.D., 1958, An experiment in the quantitative analysis of drainage basin characteristics: Compass, Sigma Gamma Epsilon, v. 36, no., 1, p. 23-38. [Horton analysis of 2 lowa basins supports laws of stream numbers \& lengths]

Orlandini, Stefano, and Lamberti, Alberto, 2000, effect of wind on precipitation intercepted by steep mountain slopes: Journal of Hydrologic Engineering, v. 5, no. 4, p. 346-354. [6 basin params. fr DEM combine $\mathrm{w} /$ modeled 3D rainfall field]

Orris, G.J., and Williams, J.W., 1984, Landslide length-width ratios as an aid in landslide identification and verification: Bulletin of the Association of Engineering Geologists, v. 21, no. 3, p. 371-375. [n=153; different I/w for diff. facies of St. Clara fm. in No. CA]

Ottoson, Patrik, 2001, Compressing digital elevation models with wavelet decomposition, in ScanGIS'2001, Scandinavian Research Conference on Geographical Information Science 8th, Ås, Norway, 25-27 June, Proceedings: p. 15-31; <http://www.nlh.no/conf/scangis2001/papers/12.pdf>. [addresses issues in adapting wavelet decomp. to 50m Sweden DEM]

Otuka, Y., 1933, The Japanese coastline (in Japanese with English summary: Geographical Revue of Japan, v. 9, p. 819-843. [coastline shape $=(L-D) / D$ where $D=$ circle diam \& $L=$ shoreline length in circle]

Overbeck, Christoph, 1997, Simulation der Topographie des Meersbodens mit Hilfe fraktaler Prozesse (in German): Universität Trier, Germany, unpublished thesis (Diplomarbeit), $180 \mathrm{p}$. [found scale-dependent breaks in fractal analyses of seafloor topo form]

Ozawa, Taku, Doi, Koichiro, and Shibuya, Kazuo, 1999, A case study of generating a digital elevation model for the Sôya Coast area, Antarctica, usinbg JERS-1 SAR interferometry: Polar Geoscience, no. 12, p. 227-239. [50m grid; 23 control pts. for $45 \mathrm{~km} \times 55 \mathrm{~km}$ area; better than GTOPO30] 
Pack, R.T., Tarboton, D.G., and Goodwin, C.N., 1999, GIS-based landslide susceptibility mapping with SINMAP, in Bay, J.A., ed., Symposium on Engineering Geology and Geotechnical Engineering, 34th, Proceedings: p. 219-231. [SINMAP = DEM-dependent software package; see Tarboton 1997]

Paillou, Philippe, and Gelautz, Margrit, 1999, Relief reconstruction from SAR stereo pairs-The 'optimal gradient' matching method: IEEE Transactions on Geoscience and Remote Sensing, v. 37, no. 4, p. 2099-2107. [pairs preproc., then filtered to get gradient (brightness?)-amplitude images]

Pal, S., 1972, A classification of morphometric methods of analysis-An appraisal: Geographical Review of India, v. 34, (cited by Lastochkin, 1987). [no info]

Palacios-Vélez, O.L., Gandoy-Bernascon, William, and Cuevas-Renaud, Baltasar, 1998, Geometric analysis of surface runoff and the computation order of unit elements in distributed hydrological models: Journal of Hydrology, v. 211, nos. 1-4, p. 266-274. [new algorithms for kinematic cascade from DEM or TIN]

Palmu, J.-P., 1997, Combining Quaternary geological and digital elevation model data, in Autio, Sini, ed., Geological Survey of Finland Current Research 1995-1996: Geological Survey of Finland Special paper 23, p. 109-116. [novel DEM visual. technique; ChromaDepth; depth parallax inmduced by color]

Panin, A.V., and Gelman, R.N., 1997, Experience applying GPS techniques to derivation of largescale digital terrain models (in Russian): Geodesiya i Cartographiya, no. 10, p. 22-27. [no info]

Papanikolaou, K., and Derenyi, E.E., 1987, GIS in support of remote sensing technology-present applications, future possibilities, in American Society for Photogrammetry and Remote Sensing-American Congress on Surveying and Mapping, International Conference, Exhibits, and Workshops on Geographic Information Systems, 2nd, GIS '87-San Francisco, October 26-30, Proceedings: v. 1, p. 333-339. [gen'l. info on DEMs, slope \& aspect, shadowed area, \& ridge extraction]

Pareschi, M.T., Favalli, M., Giannini, F., Sulpizio, R., Zanchetta, G., and Santacroce, R., 2000, May 5, 1998, debris flows in circum-Vesuvian areas (southern Italy) -insights for hazard assessment: Geology, v. 28 , no. 7 , p. $639-642$. [10-m DEM fr. 1/25K TIN: basin slope vs. shape factor, \&; superb oblique shaded-relief image of area is on cover of v. 28, no. 8]

Park, Donggyu, Cho, Hwanggue, and Kim, Yangsoo, 2001, A TIN compression method using Delaunay triangulation: International Journal of Geographical Information Science, v. 15, no. 3, p. 255-269. [reviews past methods; near-equiangular triangles.]

Parlow, E., and Schweinfurth, G., 1995, Das Digitale Geländemodell, in Fiedler, F., Klimaatlas Oberrhein Mitte-Süd: Textteil, IFG Offenbach, p. 17-18. [no info]

Pastor-Satorras, Romualdo, and Rothman, D.H., 1998a, Scaling of a slope-the erosion of tilted landscapes: Journal of Statistical Physics, v. 93, nos. 3/4, p. 477-500. [propose theory to model erosion; attempt to explain inflected shape of autocorrel. fcn.; var, comparisons w. topo-map data.]

Pastor-Satorras, R., and Rothman, D.H., 1998b, Stochastic equation for the erosion of inclined topography: Physical Review Letters, v. 80 , no. 19, p. 4349-4352. [abbreviated version of P-S \& R 1998a]

Patel, J.G., Pappalardo, R.T., Head, J.W., Collins, G.C., Hiesinger, Harald, and Sun, Jie, 1999, Topographic wavelengths of Ganymede groove lanes from Fourier analysis of Galileo images: Journal of Geophysical Research, v. 104, no. E10, p. 24,057-24,074. [dominant wavelenths vary $\mathrm{w} /$ location, fr 1-2 km to 5-10 km] 
Paulson, M.J., and Tucker, Dean, 1998, Comparison of GIS-based watershed delineation algorithms (abs.), in Hallam, C.A., and Salisbury, J.M., eds., GIS Applications in Water Resources Research-American water Resources Annual Meeting, Chicago III, November 6-10, 1994: U.S. Geological Survey, Open-file Report 98-751, p. 18. ['several' packages evaluated; no further details on results]

Payer, Julius, 1865, Orometrischer Theil, p. 6-8 in Die Adamello-Presanella-Alpen nach dem Forschungen und Aufnahmen (in German): Gotha, Justus Perthes, Ergänzungsheft (supplement volume) no. 17, to Petermanns Geographischen Mitteilungen, 36 p. [measurements of elev., slope, rel. relief, \& a ratio for various mountains in the Tyrol]

Pazzaglia, F.J., and Brandon, M.T., 2001, A fluvial record of long-term steady-state uplift and erosion across the Cascadia forearc high, western Washington state, in Pazzaglia, F.J., and Knuepfer, P.L.K., eds., The steady-state orogen-concepts, field observations, and models: American Journal of Science, v. 302, nos. 4 \& 5, p. 385-431. [elev. \& slope / distance profiles; use valley profile, terrace levels $\&$ ages, \& kinematic model to est. incision \& rock uplift across a mtn. range]

Pazzaglia, F.J., and Knuepfer, P.L.K., eds., 2001, The steady-state orogen-concepts, field observations, and models: American Journal of Science, v. 302, nos. 4 \& 5, p. 313-512; http://www.geology.yale.edu/ ajs/TableContents.html. [broad-scale work; 'neo-orometry'?; 1st \& 5th-8th of 8 papers all have morphometric contributions]

Pearce, S.J., and Melosh, H.J., 1986, Terrace width variations in complex lunar craters: Geophysical Research Letters, v. 13, no. 13, p. 1419-1422. [W < w/ distance fr rim, \& largest terrace (nearest rim) > w/ rim D; pre-collapse topo profile most important control on width; see also Leith \& McKinnon 1991]

Peckham, S.D., and Gupta, V.K., 1999, A reformulation of Horton's laws for large river networks in terms of statistical self-similarity: Water Resources Research, v. 35, no. 9, p. 2763-2777. [generalizes scaling from means to entire distribtions; supported by Shreve model]

Peeters, L., 1944, De Waarde van Enkele Kartografische Methoden bij de Analyse van een polycyclish Relief (in Dutch): Natuurwetenschnappelyk Tijdschr., v. 26, no. 1, p. 25-35. [Macar (1938) sampling technique; choice of spacing of sampling grid precludes total objectivity]

Pegler, K.H., 1999, TIN random densification-a process to minimize the ridging phenomenon in DTMs (abs.): URISA Annual Conference, Chicago, IL, August 21-25, <http://www.urisa.org/99Conference/database_design_and_maintenance.htm>. [attempt to fix 'stripes' in stereo-profiled DEMs]

Péguy, Ch.P., 1945, Recherches sur les orientations directrices de l'hydrographie dans les chaines plissées (in French): Revue de Géographie Alpine, v. 33, p. 215-237. [index of correl. betw. river orientation \& fold axes]

Péguy, Ch.P., 1947, Haute Durance et Ubaye-Esquisse physique de la zone intra-alpine des Alpes françaises du Sud (in French): Thèse Lettres Grenoble / Grenoble, Arthaud, 314 p.; also chap. III: Revue de Géographie Alpine, v. 35, no. 3. [elevation statistics, etc.]

Peikert, Ronald, and Roth, Martin, 1999, The "parallel vectors" operator-a vector field visualization primitive, in IEEE conference Visualization'99, 24-29 October, San Francisco CA, Proceedings: IEEE Computer Society Press, p. 263-270; <http://www.cg.inf.ethz.ch/ peikert/vis99/slides.pdf>. [descriptive geometry of vortex surfaces in turbomachinery; cites ridge \& valley defs. by SaintVenant, Breton de Champs, Rothe, Haralick]

Pelletier, J.D., 1999, Self-organization and scaling relationships of evolving river networks: Journal of Geophysical Research, v. 104, no. B4, p. 7359-7375. [diffusion-eqn model of landscape evol. fr. overland \& channel flow; used RiverTools] 
Penck, Albrecht, 1886, Einteilung und mittlere Kammhöhe der Pyranäen (arrangement? \& mean crest heights of the Pyrenees; in German): Jahresbericht der Geographischen Gesellschaft in München (1885), v. 11 , no. 20, p. 58-75, 64ff. ['calculated profile area by summing trapezoids defined by adjacent contours \& the contour interval' (Riedel 1907)]

Penck, Albrecht, 1886, Relative proportion of land and water on the surface of the Earth (transl. from German by J.T. Bealby): Scottish Geographical Journal, v. 2, no. 6, p. 358-362. [history of land area /water area est.; puts it at 1/2.57-1/2.60; discusses the many uncertainties]

Penck, Albrecht, 1894a, Morphometrie des Bodensees (in German; morphometry of Lake Constance): Jahresbericht der Geographischen Gessellschaft in München, p. 119-155. [tests formulae given in 1894 book; shallow lake differs in form fr others in Europe; see Peucker 1894]

Penck, Albrecht, 1894b, Orometrie in Morphologie der Erdoberfläche (in German), Stuttgart, J. Engelhorn, v. 2, p. 339-343. [summarizes mountain morphometry; comments on work of Sonklar, others]

Penck, Walther, 1922, Morphologische Analyse (in German): Berlin, Verhandlung des 20 Deutschen Geographentages Leipzig 1921, p. 122-128. [cited by D. Merriam 1981 as having quant. material; Penck's posthumous 1924 book does develop Fisher 1866 theory of slope retreat]

Perez, Albert, 2000, Source Water Protection Project-a comparison of watershed delineation methods in ARC/INFO and ArcView GIS, in Djokic, Dean, and Maidment, David, eds., Hydrologic and Hydraulic Modeling Support with Geographic Information Systems: Redlands CA, ESRI Press, p. 53-64; http://www.esri.com/library/userconf/proc99/proceed/papers/pap483/p483.htm. [compares Arcview w Spatial Analyst \& Watershed Delineator Extensions with ARC/INFO GRID AMLs]

Perlant, F., 2000, Using stereo images for digital terrain modeling: Surveys in Geophysics, v. 21, nos. 2-3, p. 201-207. [elementary intro to making a DEM from stereo images]

Pernarowski, Leszek, 1960, Application of statistical methods in investigating dune forms: Przeglad Geograficzny (Polish Geographical Review), v. 32, supplement (XIXth IGC, Stockholm), p. 57-66 + errata sheet. [Czekanowski's 'meth. of differ.' on ave. azimuth, windw. \& lee slopes, asymmetry, height]

Petzold, Bettina, Reiss, Peter, and Stössel, Wolfgang, 1999, Laser scanning-surveying and mapping agencies are using a new technique for the derivation of digital terrain models: ISPRS Journal of Photogrammetry and Remote Sensing, v. 54, p. 95-104;

http://www.fsl.orst.edu/ lefsky/isprs/1130.pdf. [Germany; more accurate \& less costly than photogrammetry; some quality caveats]

Peucker, Karl, 1894, Morphometry of the Lake of Constance: The Geographical Journal, v. 4, no. 3, p. 264-266. [English summary of Penck 1894; "... morphometric values posses an importance only when compared with the corresponding ones for other forms of the surface ..."]

Péwé, T.L., Burbank, Lawrence, and Mayo, L.R., 1967, Multiple glaciation of the Yukon-Tanana upland, Alaska: U.S. Geological Survey, Miscellaneous Investigations Map, I-507, one sheet, $1 / 500,000$ scale. [rose diagrams summarize 1088 cirque azimuths (NNE dominate)]

Philip, G.M., and Watson, D.F., 1986, A method for assessing local variation among scattered measurements: Mathematical Geology, v. 18, no. 8, p. 759-764. [surface-roughness metric computes an approx. of surface-normal vector via vector cross-products; slope]

Phillips, J.D., 1999, Divergence, convergence, and self-organization in landscapes: Annals of the Association of American Geographers, v. 89, no. 3, p. 466-488. [reviews 11 definitions of S-O; urges caution in using term] 
Pickup, Geoff, and Marks, Alan, 2000, Identifying large-scale erosion and deposition processes from airborne gamma radiometrics and digital elevation models in a weathered landscape: Earth Surface Processes and Landforms, v. 25, no. 5, p. 535-557. [map-based DEMs insuffic.; DEM fr radar altimetry \& GPS got ground not trees]

Pike, R.J., 1976, Crater dimensions from Apollo data and supplemental sources: The Moon, v. 15, p. 463-477. [large database of measurements $(H, h, D, d$, circularity) from spacecraft photogrammetry]

Pike, R.J., 2000a, Geomorphometry-diversity in quantitative surface analysis: Progress in Physical Geography, v. 24, no. 1, p. 1-20. [state-of-art review of a dozen varied topics]

Pike, R.J., 2000b, Nano-metrology and terrain modelling-convergent practice in surface characterisation: Tribology International, v. 33, no. 9, p. 593-600. [redo of Wood \& Snell 1960 illustrates potential technique for parsing an engineering surface]

Pike, R.J., 2001a, Scenes into numbers-facing the subjective in landform quantification, in Hoffman, R.R., and Markman, A.B., eds., Interpreting remote sensing imagery-human factors: Boca Raton FL, Lewis Publ. (CRC), p. 83-114. [quant. inferential steps \& analytic procedures link perception of (mostly planetary) surface form with interpretation]

Pike, R.J., 2001b, Digital terrain modeling and industrial surface metrology-converging realms: The Professional Geographer, v. 53, no. 2, p. 263-274. [automobile cylinder-wall micro-topography exemplifies methods of industrial surfacing as spatial processes]

Pike, R.J., 2001c, Digital terrain modelling and industrial surface metrology-converging crafts: International Journal of Machine Tools and Manufacture, v. 41, nos. 13-14, p. 1881-1888. examples of redundancy in morphometric analysis, fr metrology \& geomorphology]

Pike, R.J., 2001d, Geometric signatures-experimental design, first results (abs.): Int'l. Conference on Geomorphology 5th, Chuo Univ., Tokyo, Japan, August 2001; DEMs and Geomorphology, Geographic Information Systems Association (Japan) Special Publication, v. 1, p. 50-51; and Transactions, Japanese Geomorphological Union, v. 22, no. 4, p. C-192. [corrected correlations for 91 samples x 49 parameters fr $1 / 24 \mathrm{~K}$ topo map DEMs]

Pike, R.J., 2001e, "Topographic fragments" of geomorphometry, GIS, and DEMs (abs): Int'I. Conference on Geomorphology 5th, Chuo Univ., Tokyo, Japan, August 2001; DEMs and Geomorphology, Geographic Information Systems Association (Japan) Special Publication, v. 1, p. 34-35. [misc. observations \& recommendations on current state of art]

Pinchemel, Philippe, 1950, L'analyse morphométrique des réseaux hydrographiques (in French; morphom. anal. hydro. networks): Comptes Rendues des Séances de l'Académie des Sciences (Paris), v. 230, 5 Feb., p. 556-557. [presumably Hortonian analysis]

Piper, D.J.W., and Evans, I.S., 1967, Computer analysis of maps using a pencil follower: Geographical Articles (Cambridge Univ., UK), v. 9, p. 21-25. [stored \& manipulated digitized versions of contours fr printed maps]

Pitty, A.F., 1969, Some problems in selecting a ground-surface length for slope-angle measurement: Revue de Géomorphologie Dynamique, v. 17, no. 2, p. 66-71. [optimal length = ?]

Pitty, A.F., 1970, A scheme for hillslope analysis, II. Indices and tests for differences: University of Hull (UK), Occasional Papers in Geography, no. 17, 56 p. [fr. Ph.D. thesis; reduces descr. to series of indices: freq. distr., profiles, component shapes, irregularities., position on profile] 
Piwowar, A., 1902, Über Maximalböschungen trockener Schuttkegel und Schutthalden (in German): Vierteljahrsschrift d. Nat. forsch. Gesellschaft Zürich, v. 48, p. 43-56. [measured profiles of talus slopes]

Planchon, Olivier, Esteves, Michel, Silvera, Norbert, and Lapetite, J.-M., 2002, Microrelief induced by tillage-measurement and modelling of surface storage capacity: Catena, v. 46, no. 2-3, p. 141157. [random roughness param. fr $5 \mathrm{~cm}$ DEM spacing @ 1 mm vert. accuracy]

Playfair, John, 1802, § 99 \& 111, in Illustrations of the Huttonian Theory of the Earth: Edinburgh, facsimile reprints 1956, Urbana, Univ. Illinois Press, \& 1964, New York, Dover, 528 p. [a geometer, \& one of the 1st in Britain to teach modern math. analysis \& recent work from Europe, he early recognized key relations (generalized as 'Playfair's Law') quantified only much later-stream size proportional to that of its valley; channels \& valleys of streams \& tributaries ('... and valley side slopes' implied) meet on same level, p. 102; stream-junction angles are acute upstream of junction, p. 113-14 (see also Kant, 1803, p. 18).]

Plazanet, C., and Spagnuolo, M., 1998, Seafloor valley shape modeling, in Spatial Data Handling '98 Conference, 11-15 July, Vancouver, BC, Proceedings: p. 751. [no info]

Portnova, O.V., 1975, Distinctive features of stereophotogrammetric measurements in derivation of digital terrain models (in Russian): Geodesiya i Cartographiya, no. 6, p. 24-27. [no info]

Potter, D.M., 1957, Measurements of runway roughness of four commercial airports: Langley Field, VA, Aeronautical Laboratory, National Advisory Committee for Aeronautics, NACA Research Memorandum RM L56126, 86 p. [raw data for elev. profiles surveyed w/ level, rod, \& tape at 2' $(0.6 \mathrm{~m})$ interval \& $0.01 "$ vert. precision interpolated to $0.001 " ; 2$ unlabeled PSD plots for one runway]

Premoze, Simon, Thompson, W.B., and Shirley, Peter, 1999, Geospecific rendering of alpine terrain: Eurographics Workshop on Rendering, 10th, EGWR'99, Grenada, Spain, 21-23 June, (paper not in proceedings); http://www.cs.utah.edu/vissim/papers/snowTerrain/. [adding color aerial imagery, shading \& shadowing for time of day, snow cover, \& 3-D instancing of trees and brush to DEM much improve visual quality]

Press, Harry, and Tukey, J.W., 1956, Power spectral methods of analysis and their applications to problems in airplane dynamics, in Durbin, E.C., ed., Flight Test Manual: North American Treaty Organization AGARD (Advisory Group for Aeronautical Research and Development), Part IVC, p. 141; also in The Collected Works of John W. Tukey v. I-Time Series, 1949-1964, Wadsworth Advanced Books \& Software: Monterey, CA., p. 185-255]. [actual work may date closer to 1954 (see Walls et al. 1954); many PSD examples; comp. details; introduced 'prewhitening, simplifying choice of window]

Prior, D.B., and Renwick, W.H., 1980, Landslide morphology and processes on some coastal slopes in Denmark and France: Zeitschrift fur Geomorphologie, Supplementband 34, p. 63-86. [surveyed profiles \& slope-freq. distributions of clay slopes]

Puppo, E., Davis, L., De Menthon, D., and Teng, Y., 1994, Parallel terrain triangulation: International Journal of Geographical Information Systems: v. 8, no. 2, p. 105-128. [developed \& implemented (for 1st time) a parallel algorithm for Delaunay triang.]

\section{$\mathbf{R}$}

Raasch, W., 1979, Photometric measurement of terrain roughness: Journal of Terramechanics, v. 16, no. 2, p. 87-111. [no info]

Rachocki, Andrzej, 1981, Alluvial Fans-an attempt at an empirical approach: Chichester \& New York, Wiley, 161 p. $\quad$ [intro to quant. p. 23-24, \& randon-walk model p. 111-143] 
Raczkowski, M., Wojcik, A., and Zuchiewicz, W., 1985, Mloda tektonika Karpat w swietle analizy morfostrukturalnej (in Russian): Zesz Nauk AGH, kwart Geologia, v. 11, no. 2, p. 38-83. [isoline maps of valley height \& stream length in the Carpathians; method of Filosofov 1960, 63, 70]

Radebaugh, Jani, and Christiansen, E.H., 1999, Terrestrial pluton and planetary caldera sizes-implications for the origin of calderas (abs.): EOS, Transactions, American Geophysical Union, v. 80, no. 46, Supplement, p. F635. [freq. distr. of plutons based on Pike \& Clow 1981 caldera data]

Radionov, V.A., 1996, On accuracy of digital representation of relief (in Russian): Geodesiya i Cartographiya, no. 10, p. 34-37. [no info]

Râdulescu, D., 1975, Digitalizarea suprafetelor (in Rumanian, digital modeling of surfaces): Symposium of Photogrammetry, Rumanian Committee of Photogrammetry, Comission V, Bucharest, Proceedings: paging unknown. [digital model of irregularly-spaced elevs fr profiles; yields slopes]

Raines, G.L., 2002, Description and comparison of geologic maps with FRAGSTATS-a spatial statistics program: Computers and Geosciences, v. 28, no. 2, p. 169-177. [1st Earth-science use? implem. in Patch Analysis extension of ESRI's Arcview by converting polygon files to grids; potential applic. to drainage basins \& topo. facets]

Ramsey, E.W. III, Nelson, G.A., Laine, S.C., Kirkman, R.G., and Topham, Willie, 1998, Generation of coastal marsh topography with radar and ground-based measurements: Journal of Coastal Research, v. 14, no. 3, p. 1158-1164. [ERS-1 SAR flood extent + contours; 5-9X better; eval. errors]

Rana, Sanjay, and Morley, Jeremy, 2002, Surface Networks: London, UK, University College, Centre for Advanced Spatial Analysis, Working paper 43, 72 p.; http://www.casa.ucl.ac.uk/working_papers/Paper43.pdf. [reviews surface-specific abstraction of 2D surfaces, 1859-2000]

Range, Wolfgang, 1961, Morphometrische Untersuchungen in den Einzugsgebieten der Bayerischen Alpenflüsse (Morph. inves. in catchments of Bavarian alpine rivers, in German): Veröffentlichung aus dem Arbeitsbereich der Bayer. Landesstelle für Gewässerkunde in München, 62 p. [defines \& calc. area, mean slope \& elev, drainage density, etc. fr contour maps]

Rao, L.A.K., Asif, Mohammed, and Ali, S.R., 1997, Quantitative hydrogeomorphic investigation of Kali-Sindh sub-basin within Rajgarh district, Madhya Pradesh, India: Indian Journal of Earth Sciences, v. 24, nos. 3-4, p. 45-50. [Horton/Strahler analysis; geol. structure does not affect stream topology]

Rapp, Anders, 1967, On the field survey of hillslopes: Revue de Géomorphologie Dynamique, v. 17, no. 4, p. 152 . [favors 5-m or 10-m slope-length sampling interval]

Rasehorn, F., 1911, Die Flußdichte im Harze und in seinem nördlichen Vorlande (in German; drainage density in the Harz ...): Univ. Halle, dissertation, 58 p., Zeitschrift für Gewässerkunde, v. 9, p. 1-56. $[x=A / n, A=$ basin area $\& n=$ number of segments $]$

Ravenstein, M.A., 1841, Some observations on relief maps: Report of the Tenth Meeting of the British Association for the Advancement of Science-Notices and abstracts of communications, Geology Section, Glasgow, August 1840, v. 9, p. 122-123. [invented raised relief (stamped in plastic); his 1838 'Plastic Atlas']

Ray, C.K., 1994, Representing visibility for siting problems: Ph.D, Thesis, Rensselaer Polytechnic Institute, Troy, New York, April, paging unknown. [forms core of Franklin \& 1994 on missile battery siting] 
Ray, C.K., 1994, A new way to see terrain: Military Review, v. 2, no. 1, p. 81-89. [3D representation
[3 much quicker, more accurate \& efficient than 2D map]

Reeb, Georges, 1946, Sur les points singuliers d'une forme de Pfaff completement integrable ou d'une fonction numérique (in French; On the singular points of a completely integrable Pfaffian form or of a numerical function): Paris, Comptes Rendus de L'Acad. des Sciences, v. 222, p. 847-849. [proposed topological graph (a critical-point graph) that defines the skeleton of a surface]

Rees, W.G., 1992, Measurements of the fractal dimension of ice-sheet surfaces using Landsat data: International Journal of Remote Sensing, v. 13, p. 663-671. [semivariogram analysis, other]

Rees, W.G., 1998, A rapid method of measuring snow-surface profiles: Journal of Glaciology, v. 44, no. 148 , p. $674-675$. [photo against portable black back-plate + image-processing $=$ topo profile]

Rees, W.G., 2000, The accuracy of digital elevation models interpolated to higher resolutions: International Journal of Remote Sensing, v. 21 , no. 1 p. 7-20. [bilinear or bicubic interp. OK; rms acc. of interp. DEM $=0.2-0.6$ std. dev. of height diff. of adj. elevs.]

Remond, Agnès, Beaudoin, André, and King, Christine, 1999, SAR imagery to estimate roughness parameters when modelling runoff risk: International Journal of Remote Sensing, v. 20, no. 13, p. 2613-2625. [six params. of periodic \& random roughness for 4 classes of agric. fields]

Rémy, Frédérique, Legresy, Benoît. and Testut, Laurent, 2001, Ice sheet and satellite altimetry: Surveys in Geophysics, v. 22, no. 1, p. 1-29. [reviews modern polar ice-sheet mensuration]

Rencz, Andy, Leclerc, Yvonne, Wright, Dan, Bonham-Carter, G.F., and Balma, Rob, 1991, Digital topography for earth sciences (Topographie numerique et sciences de la terre): Geos (Ottawa), v. 20 , no. 2, p. 1-6. [no info]

Reniger, Anna, 1954, Significance of land relief for agriculture (in Polish with English summary + fig. \& table captions: Przeglad Geograficzny (Polish Geographical Review), v. 26, no. 4, p. 37-47. [data for 6 areas fr I/100K 5-class slope map; correl. w/ veg. \& soils]

Renssen, H., and Knoop, J.M., 2000, A global river routing network for use in hydrological modeling: Journal of Hydrology, v. 230, nos. 3-4, p. 230-243. [fr. TerrainBase 30' DEM (NGDC 1997); basin areas test well re publ. data]

Replumaz, A., Lacassin, R., Tapponnier, P., and Leloup, P.H., 2001, Large river offsets and PlioQuaternary dextral slip rate on the Red River fault (Yunnan, China): Journal of Geophysical Research, v. 106, no. B1, p. 819-836. [drainage area/apparent offset, river spacing, updownstream correl.]

Reuschle, F., 1869, Kritische Miszellen zur Geographie I. Das Maß der Küstenentwicklung und Grenzentwicklungs-Koeffizienten überhaupt (Critical goal ? of geography I. measuring generalized coefficients of coastal and border convolution): Zeitschrift der Gesellschaft für Erdkunde zu Berlin, v. 4, p. 193-199. [coastal convolution $=U / 2 \sqrt{F} \Pi: U=$ perimeter of coast, $F=$ area enclosed; also $\mathrm{r} 1=\sqrt{ } \mathrm{F} / \Pi$; see Rohrbach, 1890]

Ribolini, Adriano, 2000, Relief distribution, morphology and Cenozoic differential uplift in the Argentera Massif (French-Italian Alps): Zeitschrift für Geomorphologie, v. 44, no. 3, p. 363-378. [R analysis after Burbank 1992, Gilchrist et al 1994, \& Fielding et al. 1994]

Rice, R.M., Corbett, E.S., and Bailey, R.G., 1969, Soil slips related to vegetation, topography, and soil in southern California: Water Resources Research, v. 5, no. 3, p. 647-659. [ $n=200$; slope gradient $>80 \%$ for all landslides; prox. to streams, veg. type \& density important; discrim. analysis] 
Rice, R.M., and Foggin, G.T. III, 1971, Effect of high intensity storms on soil slippage on mountainous watersheds in southern California: Water Resources Research, v. 7, no. 6, p. 14851496. [topo data incl. aspect, vol., area, length, width; discrim. analysis, slope most important]

Rice, S.P., and Church, Michael, 2001, Longitudinal profiles in simple alluvial systems: Water Resources Research, v. 37, no. 2, p. 417-426. [elev./dist. for stream links are expoential or quadratic]

Rice-Snow, Scott, 1998, Fractal characteristics of drainage basin boundaries in Puerto Rico, in Johnson, A.I., and Fernandez-Jauregui, C.A., eds., Hydrology in the Humid Tropic Environment: Symposium, Kingston, Jamaica, 17-23 November, 1996, Proceedings: IAHS Publication no. 253, p. 195-201. [6 large basins; D (1.06-1.11) like that of temperate basins]

Rice-Snow, Scott, and Russell, Joshua, 1999, Long-range persistence of elevation and relief values along the Continental Divide in the conterminous U.S., in International Conference on GeoComputation, 4th, Fredericksburg VA, Mary Washington College, 25-28 July, GeoComputation 99: http://www.geovista.psu.edu/geocomp/geocomp99/Gc99/043/gc_043.htm. [both params. robustly self-affine, $\mathrm{D}=1.0-1.2$, fr. Mex. to Can.]

Richards, K.S., 1978, Yet more notes on the drainage density-basin area relationship: Area (London), v. 10, no. 5, p. 344-353. [w/ discussion by Pethick, Ferguson, \& Gerrard]

Riedel, Wilhelm, 1907, Die Einteilung des Odenwaldes in orographische Gruppen-Ein Beispiel für die Verwertung der Ergebnisse orometrischer Untersuchungen zur Einteilung von Gebirgen (in German; dividing the Odenwald into orogr. sections-an example using results of orometric investig. to classify mountains): Univ. Gießen, Dissertation, 54 p. [using 14 ridge params. (4 'improved' over Sonklar's) fr new 1/25K topo map, partitions area into hierarchy of 3 main divs. \& 4 divs. containing 17 dominant ridges]

Rieger, J.H., 1997, Topographical properties of generic images: International Journal of Computer Vision, v. 23, no. 1, p. 79-92. [both computer vision (grey values) \& Earth science (terrain heights) need geometric descr. of surface features, e.g. watercourses, a non-trivial problem; prefers Jordan 1872a definition of critical lines to Rothe 1915; found 1808 Dupuis de Torcy \& Brisson ref. in Müller 1919]

Riitters, K.H., O'Neill, R.V., Hunsaker, C.T., Wickham, J.D., Yankee, D.H., Timmins, S.P., Jones, K.B., and Jackson, B.L., 1995, A factor analysis of landscape pattern and structure metrics: Landscape Ecology, v. 10, no. 1, p. 23-39. [best discussion to consult after the FRAGSTATS manual]

Riley, S.J., DeGloria, S.D., and Elliot, R., 1999, A terrain ruggedness index that quantifies topographic heterogeneity: Intermountain Journal of Sciences, v. 5, no. 1-4, p. 23-27. [no details]

Rinaldo, Andrea, and Rodríguez-Iturbe, Ignacio, 1998, Scaling in river networks, in Sposito, Garrison, ed., Scale Dependence and Scale Invariance in Hydrology: Cambridge, UK, Cambridge University Press, p. 61-87. [Hack's Laws = outgrowth of fractality, which exists imperfectly within upper \& lower limits]

Rinaldo, Andrea, Fagherazzi, Sergio, Lanzoni, Stefano, Marani, Marco, and Dietrich, W.E., 1999, Tidal networks 2. Watershed delineation and comparative network morphology: Water Resources Research, v. 35, no. 12, p. 3905-3917. [quantify network properties, incl. power-law relations]

Rinaldo, Andrea, Fagherazzi, Sergio, Lanzoni, Stefano, Marani, Marco, and Dietrich, W.E., 1999, Tidal networks 3. Landscape-forming discharges and studies in empirical geomorphic relationships: Water Resources Research, v. 35, no. 12, p. 3919-3929. [simple model predicts local peak ebb \& flood Q; tested OK on Venice Lagoon] 
Ritchie, J.C., 1995, Airborne laser altimeter measurements of landscape topography: Remote Sensing of the Environment, v. 53, no. 2, p. 91-96. [4000 data/sec. at 5cm-res.; GPS control; microtopo. elevs.]

Ritter Carl, 1806, Sechs Karten von Europa mit erkärendem Texte (in German): Schnepfenthal. [map V, 'Die Gebirgshöhen in Europa, ihre Vegetationsgrenzen \& verschiedene Luftschichten', altho rather primitive (no contour lines), is perhaps the 1st layer-tint elevation map]

Ritter, Carl, 1826, Über geographische Stellung und horizontale Ausbreitung der Erdteile (Geogr. position \& horizontal extent of the continents; in German): Berlin, lecture at Kgl. Akad. d. Wissenschaften, December 14, published 1852 in Einleitung zur allgemeinen vergleichenden Geographie, und Abhandlungen zur Begründung einer mehr wissenschaftlichen Behandlung der Erdkunde: Berlin, Sammlung der Abhandlungen Ritters, p. 103-128. [calculated circularity index for the continents; related cont. area to square of perimeter or area of smallest circumscribed circle; the 1st-ever spatial morphometry? see 1861 Gage transl.]

Ritter, Carl, 1828, Bemerkungen über Veranschaulichungsmittel räumlicher Verhältnisse bei graphischen Darstellungen durch Form und Zahl (Illustrative methods for spatial properties using diagrams of form \& number; in German): Berlin, lecture at Kgl. Akad. d. Wissenschaften, January 17, published 1852 in Einleitung zur allgemeinen vergleichenden Geographie, und Abhandlungen zur Begründung einer mehr wissenschaftlichen Behandlung der Erdkunde: Berlin, Sammlung der Abhandlungen Ritters, p. 129-150. [early spatial morphometry; includes 1826 calc. of circularity index of the continents; see 1861 Gage transl.]

Robison, E.G., Mills, K.A., Paul, James, Dent, Elizabeth, and Skaugset, Arne, 1999, Digital elevation models (DEMs) and ground-slope comparisons, pp. 32-39 in Storm impacts and landslides of 1996-Final Report: Oregon Department of Forestry, Forest Practises Technical Report no. 4, 145 p. [30-m DEM slopes (fr 40' Cl map) poorly correl. w/ site slope (smaller scale length \& better source maps)]

Rodda, J.C., 1970, A trend-surface analysis trial for the planation surfaces of north Cardiganshire: Transactions of the Institute of British Geographers, Publ. no. 50, p. 107-114. [early applic. of TS technique to topo.]

Roering, J.J., Kirchner, J.W., and Dietrich, W.E., 1999, Evidence for nonlinear, diffusive transport on hillslopes and implications for landscape morphology: Water Resources Research, v. 35, no. 3, p. 853-870. [back to Davis \& Gilbert; transport law ₹ slope angle; field agreement (2-m DEM)]

Roering, J.J., Kirchner, J.W., and Dietrich, W.E., 2001, Hillslope evolution by nonlinear, slopedependent transport-steady state morphology and equilibrium adjustment timescales: Journal of Geophysical Research, v. 106, no. B8, p. 16,499-16,513 (minor correction in 106, B11, 26,787). [simulations; suggest hilltop curvature, not relief \& slope, indicates tectonic forcing]

Roeschmann, Günter, and Lehmeier, Friedmut, 1993, Vorschläge zur morphographischen Kennzeichnung des Oberflächenreliefs für punktbezogene geowissenschaftliche Profilaufnahmen (REPA) (in German: proposals for the morphographic characterization of surface relief for geoscientific data acquisition at drilling sites and exposures): Geologisches Jahrbuch, v. F26, no. 1, p. 3-46. [exhautive system for relief char. in plan \& profile, 'what is to be descr.' Kugler, Demek infl.]

Rogers, C.A., 1993, Describing landscapes-indices of structure: Burnaby, BC, Simon Fraser University, unpublished M.Sc. thesis, 170 p. $\quad$ [landscape ecology; used metrics now in FRAGSTATS]

Romieux, A., 1890, Relations entre la déformation actuelle de la croûte terrestre et les densités moyennes des terres et des mers (in French;): Comptes Rendus Hebdomadaires des Séances de l'Académie des Sciences / Institut de France, v. 111, p. 994-996. [tries to reconcile mean land \& sea elevs. with geophysics in light of Challenger Expedition data] 
Romstad, Bård, 2001, Improving relief classification with contextual merging, in ScanGIS'2001, Scandinavian Research Conference on Geographical Information Science 8th, Ås, Norway, 25-27 June, Proceedings: p. 3-13; <http://www.nlh.no/conf/scangis2001/papers/15.pdf>. [more uniform, less 'noisy' terrain types; $10 \mathrm{~m}$ DEM of Spitzbergen]

Rosiek, M.R., Kirk, R., and Howington-Krause, A., 1999, Lunar south pole topography derived from Clementine imagery, in Workshop on new views of the Moon II-understanding the Moon through the integration of diverse datasets: Houston TX, Lunar and Planetary Institute, LPI Contribution no. 980, p. 52-53. [fr Clementine altimetry; $90^{\circ}-65^{\circ} \mathrm{S}$ at $1 \mathrm{~km} / \mathrm{px}$; color map]

Rosiwal August, 1898, Über geometrische Gesteinsanalysen. Ein einfacher Weg zür ziffermassigen Feststellung des Quantitätsverhältnisses der Mineral-Bestandteile gemengter Gesteine (in German; Geometric rock analysis. A simple method for numerical determination of quant. ratios of mineral fractions of mixed rocks; transl. H.G. Ranson, 1960, Royal Aircraft Establ., Farnborough, U.K., Lib. Trans. \#871): Verhandl. der Kaiserlich-Koeniglichen Geologischen Reichsanstalt, Vienna, 5/6, p. 143-175. [parallel-line sampling to obtain area (\& thus volume, after stereological principle of Achille Delesse 1847) of mineral constituents in rocks fr microscope analysis of thin sections; directly adapts to area measurement on maps]

Rossi, M.J., 1999, Plan-curvature effect on the formation of tumuli on shield volcanoes-an example from Leitin lava flow field in Iceland: Zeitschrift für Geomorphologie, Supplementband 114, p. 1-10. [tumuli freq., plancurv., \& slope / dist. fr vent; freq. of tumulus $H, W, \& A$ ]

Rosu, Al, and Balteanu, D., 1969, Caracterizarea cantitativa si clasificarea unitatilor geomorfologice din Romania, pe baza varietatii reliefului (Quantitative characterization and classification of geomorphic units in Romania based on relief variations): Terra (Helsinki), v. 1, no. 1, p. 28-31. [defined 18 units on relief energy \& dissection]

Rothe, Rudolf, 1915, Zum problem des talwegs (in German; on the drainage-line problem): Sitzungsberichte der Berliner Math. Gesellschaft, v. 14, p. 51-69. [key to older French refs.; citing math. definition (Saint-Venant 1852) \& theorem (Breton de Champ 1854), Rothe criticizes Jordan $1872 a$ \& rather vaguely defines valley (\& ridge) lines (flow-lines where other flow-lines converge \& join to form a stream channel) as points where slope is locally minimal re/ other points at same elev.]

Roubal, J., and Poiker, T., 1985, Automated contour labeling and the contour tree, in Auto-Carto 7 , International Symposium on Computer-Aided Cartography, 7th, Washington, D.C., March 11-14, Proceedings: p. 472-481. [data structure evolved into Kweon \& Kanade 1994 'topographic change tree']

Rouse, W.C., 1984, Flowslides, chap. 12 in Brunsden, Denys, and Prior, D.B., eds., Slope Instability: London, Wiley, p. 491-522. [obs. on approx. geometries of $\sim 20$ flowslide (e.g. Gros Ventre, Blackhawk, Sherman, Madison Cyn.) rupture surfaces, tracks, \& deposits]

Rowbotham, D.N., and Dudycha, Douglas, 1998, GIS modelling of slope stability in Phewa Tal watershed, Nepal: Geomorphology, v. 26, nos. 1-3, p. 151-170. [creates irreg. 'terrain units' fr DEM maxs \& mins fr elev. \& curvature surfaces]

Rowland, S.K., and Garbeil, Harold, 2000, Slopes of oceanic basalt volcanoes, in Mouginis-Mark, P.J., Crisp, J.A., and Fink, J.H., eds., Remote Sensing of Active Volcanism: Washington, DC, American Geophysical Union, Geophysical Monograph 116, p. 223-247. [DEMs \& slope for 15 shields in 4 regions; plot slope vs. elev. \& \% total elev.]

Rowland, S.K., MacKay, M.E., Garbeil, H., and Mouginis-Mark, P.J., 1999, Topographic analyses of Kíluea volcano, Hawai'i, from interferometric airborne radar: Bulletin of Volcanology, v. 61, no. 1-2, p. 1-14. [10-m DEM, vert. accuracy 1-2 m; compare w/ USGS DEM \& ground truth survey] 
Rubey, W.W., 1952, Final stages in development of present topography, p. 122-136 in Geology and mineral resources of the Hardin and Brussels quadrangles (in Illinois): U.S. Geological Survey, Professional Paper 218, 179 p. [eqn. relates stream-surface slope to channel depth/width, load, particle size, \& discharge; used many results from G.K. Gilbert's 1914 flume experiments]

Rudenko, M.V., Dzhumaylo, N.A., and Berezhnyy, B.V., 1983, A computer method for the statistical analysis of bottom relief data: Oceanology, v. 22, no. 5, p. 630-632. [morphometry, relief, statistical analysis]

Ruffin, B.W., 1965, Lunar heights from shadows automatically: Photogrammetric Engineering, v. 31, no. 5 , p. 741-743. [qual. descript. of quant. processes for getting spot heights for the ACIC lunar charts]

Ruggles, C.L.N., Medyckyj-Scott, D.J., and Gruffydd, A., 1993, Multiple viewshed analysis using GIS and its archaeological application-a case study in northern Mull, in Andresen, J., Madsen, T., and Scollar, I., eds., Computing the past-Computer Applications and Quantitative Methods in Archaeology, CAA92 Aarhus: Aarhus, Denmark, Aarhus University Press, p. 125-131. [used to solve historico-archeological problems]

Ruhe, R.V., 1967, Geomorphic surfaces and surficial deposits in southern New Mexico: Socorro NM, State Bureau of Mines and Mineral Resources, Memoir 18, 65 p. [eqns. of profiles \& contours on fans, pediments, \& piedmonts; fits ellipse to plan of $\mathrm{mtn}$. range]

Ruhe, R.V., and Walker, P.H., 1968, Hillslope models and soil formation, I, in International Congress of Soil Science, 9th, Adelaide, Australia, Transactions: v. 4, p. 551-560. [parsed geomorph. units fr concavo-convexity \& slope gradient, length, \& width; proposed quant. descr. but did none]

Russell, E.C., Kumler, Mark, and Ochis, Heidi, 1995, Identifying and removing systematic errors in USGS DEMs, in Conference, GIS in the Rockies, Denver, CO, 25-27 Sept., Proceedings: paging unknown; http://www.ctmap.com/gis_journal/destripe.pdf. [row-by-row DEM power-spectrum estimates better than low-pass filtering]

Russell, E.C., and Ochis, Heidi, 1995-96?, Mitigation methods for systematic errors in USGS DEMs: Boulder, CO, Computer Terrain Mapping, Inc., 8 p.;

http://www.ctmap.com/gis_journal/filtering_wp.pdf. [good review of Level $17.5^{\prime}$ problem; improvements fr power-spectrum (manual profiling) or global + local filtering (Gestalt Photomapper II)]

Rutkis, Janis, 1971, Tables on relative relief in middle and western Europe: Uppsala Universitet, Naturgeografiska Institutionen, Uppsala, Sweden, UNGI Rapport 9, 22 p. [+ 2 appendices with 69 pages of tables of elevation; see William-Olssen, 1975]

Ruxton, B.P., 1958, Weathering and subsurface erosion in granite at the piedmont angle, Balo, Sudan: Geological Magazine, v. 95, no. 5, p. 353-377. [quant. data on slope profiles suggest correl. betw. slope \& lithology]

Rzhanitsky, N.A., 1960, Morphological and hydrological regularities of the structure of the river net (translated from the Russian by D.B. Krimgold): U.S. Agricultural Research Service, 380 p. [quant. drainage analysis applied to USSR hydro. problems; big. Engl. biblio]

\section{S}

Sadahiro, Yukio, 2001, Analysis of surface changes using primitive events: International Journal of Geographic Information Science, v. 15, no. 6, p. 523-538. [modify 'structural graph' (Warntz topology; critical points \& integral curves)] 
Sagar, B.S.D., 2002, Qualitative models of certain discrete natural features of drainage environment: New Delhi, India, Allied Publishers Ltd., ca. 225 p, in-press. [a morphometric monograph ('qualitative' a misnomer) on spatial fractal char. of rivers, math. morphology, '1-D maps']

Sagar, B.S.D., and Murthy, K.S.R., 2000, Generation of a fractal landscape using nonlinear mathematical morphological transformations: Fractals, v. 8, no. 3, p. 267-272. [fr 3r-order Koch quadric fractal; 'resembles landscape (w/) alluvial fans, of interest to theoretical geomorphologists']

Sagar, B.S.D., Murthy, M.B.R., Rao, C.B., and Raj, Baldev, 2002, Morphological approach to extract ridge and valley connectivity networks from digital elevation models: International Journal of Remote Sensing, v. 23, in press, 9 p. [math. morph. transform. of grey-scale image of DEM; Gaussian blurring technique]

Sagar, B.S.D., and Rao, B.S.P., 1995, Fractal relation on perimeter to the water body area: Current Science (Bangalore, India), v. 68, no. 11, p. 1129-1130. [the old (mid 19th Cent.) area/perimeter problem yet again]

Sagar, B.S.D., and Srinivas, D., 1999, Estimation of number-area-frequency dimensions of surface water bodies: International Journal of Remote Sensing, v. 20, no. 13, p. 2491-2496. [math. morph.; set theory-based transform, the 'cascade of erosion-dilation' for 1700 lakes]

Sagar, B.S.D., Venu, M., and Murthy, K.S.R., 1999, Do skeletal networks derived from water bodies follow Horton's laws?: Mathematical Geology, v. 31, no. 2, p. 143-154. ['yes', acc. to Melton's law, tested on Nizamsagar Reservoir]

Sagar, B.S.D., Venu, M., and Srinivas, D., 2000, Morphological operators to extract channel networks from digital elevation models: International Journal of Remote Sensing, v. 21, no. 1 p. 21-29. [mathematical morphology simplifies DEM-to-network transf. from a simulated DEM]

Saint-Venant, A.J.C.B. (Adhémar Jean-Claude Barré) de, 1852, Sur les surfaces à plus grande pente constante ainsi que sur les lignes courbes parallèls, sur celles qu'on peut appeler anti-parallèls, et sur les lignes de faîte et de thalweg des surfaces courbes en général (in French; on surfaces of greater constant slope as well as curved parallel lines, anti-parallels, and ridge \& thalweg lines of curved surfaces in general): Bulletin de la Société Philomathématique de Paris, March 6 session, $p$. 24-29. [mathematician \& civil engineer; 2 theorems here; this possibly 1 st identify of ridges \& drains as points of minimum slope-compared to other points at same elevation, altho did not specify flow-lines (slope $=$ zero) that form drainage pattern (see Haralick 1983)]

Sakaguchi, Yukata, 1968, On mountain-forming processes: Geographical Review (Japan), v. 77, p. 284-310. [used relative relief \& summit altitude]

Salisbury, N.E., 1980, Thresholds and valleys widths in the South River basin, lowa, in Coates, D.R., and Vitek, J.D., eds., Thresholds in Geomorphology: London, George Allen and Unwin, p. 103129. [problem of valley widening approached by regression analysis of basin area, reach length, slope, etc.]

Sallenger, A.H. Jr., Krabill, William, Brock, John, Swift, Robert, Jansen, Mark, Manizade, Serdar, Richmond, Bruce, Hampton, Monte, and Eslinger, David, 1999, Airborne laser study quantifies El Niño-induced coastal change: Eos, Transactions, American Geophysical Union, v. 80, no. 8, p. 89, 92, 93. [Airborne Topo. Mapper (ATM): 2-m spacing \& 14-cm rms vert. error show erosion]

Sandwell, D.T., and Smith, W.H.F., 2001, Bathymetric estimation, in Fu, L.-L., and Cazenave, eds., Satellite Altimetry and Earth Sciences-A handbook of techniques and applications: New York, Academic Press, p. 441-457. [state-of-art overview] 
Sapozhnikov, V.B., and Foufoula-Georgiou, Efi, 1999, Horizontal and vertical self-organization of braided rivers: Water Resources Research, v. 35, no. 3, p. 843-851. [dynamic scaling emerges as critical state approached; braided rivers are S-O systems]

Sauermann, G., Rognon, P., Poliakov, A., and Herrmann, H.J., 2000, The shape of the barchan dunes of Southern Morocco: Geomorphology, v. 36, nos. 1-2, p. 47-62. [h/W; $n=8$; claim shape not necessarily size-invariant]

Saunders, William, 2000, Preparation of DEMs for use in environmental modeling analysis, in Djokic, Dean, and Maidment, David, eds., Hydrologic and Hydraulic Modeling Support with Geographic Information Systems: Redlands CA, ESRI Press, p. 29-52;

http://www.esri.com/library/userconf/proc99/proceed/papers/pap802/p802.htm. [integrates vector hydro layer into DEM prior to watershed delineation ('stream burning')]

Savigear, R.A.G., 1967, On surveying slope profiles: Revue de Géomorphologie Dynamique, v. 17, no. 4, p. 153 . [see also de Béthune, \& Rapp, same source]

Savigear, R.A.G., 1967, The analysis and classification of slope profile forms, in Macar, Paul, ed., L'evolution des versants: Liége, p. 271-287. [last (?) Savigear paper on slope profiles (1st in 1952)]

Schaber, G.G., Pike, R.J., and Berlin, G.L., 1979, Terrain-analysis procedures for modeling radar back-scatter: U.S. Geological Survey Open-file Report 79-1088, 20 p. +41 p. appendix. [the Pike et al. 1968-70 software package; appendix has entire FORTRAN code \& worked example]

Scheer, Roderich, 1933, Die zahlenmäßige Erfassung der Reliefenergie und ihre Darstellung (numerical capture of relief energy and its representation, in German): Geogr. Wochenschrift (Breslau), v. 1, no. 17, p. 463-464. [brief note on relative-relief technique]

Scheidegger, A.E., 1967, A stochastic model for drainage patterns into an intermontane trench: Bulletin of the International Association of Scientific Hydrology, v. 12, no. 1, p. 15-20. [introduced the directed random network, the simplest possible reasonable flow model]

Scheidegger, A.E., 1968, Horton's law of stream numbers: Water Resources Research, v. 4, no. 3, p. 655-658. ['law' math. consistent only for structurally Hortonian networks, which are rare in nature]

Scheidegger, A.E., and Langbein, W.B., 1966, Probability concepts in geomorphology: U.S. Geological Survey Professional Paper 500-C, p. C1-C14. [var. examples of randomness concepts in understanding landforms \& rivers]

Schenk, P.M., 2002, Thickness constraints on the icy shells of the galilean satellites from a comparison of crater shapes: Nature, v. 417 , no. 6887, p. 419-421. [d/D plots for Callisto, Ganymede, \& Europa fr stereo DEMs, photoclinometry, \& shadow lengths]

Schenk, P.M., Hargitai, Henrik, Wilson, Ronda, McEwen, Alfred, and Thomas, Peter, 2001, The mountains of lo-global and geological perspectives from Voyager and Galileo: Journal of Geophysical Research, v. 106, no. E12, p. 33,201-33,222. [L, W, A, h (mean h=6.3 km) for 115 mtns. \& 541 volcanoes (mean $h=17.5 \mathrm{~km}$ ); $\mathrm{h}$ fr shadow lengths, twilight illum., limb profiles, \& stereo elev. mapping)]

Schick, A.P., 1964, Accuracy of the 1/20,000 topographic maps of Israel for morphometric studies: Bulletin of the Israel Exploration Society, v. 28, no. 1, p. 43-54. [1/2500 maps better than 1/20K maps, by $\sim 10 \%]$

Schilling, S.P., 1998, LAHARZ-GIS programs for automated mapping of lahar-inundation hazard zones: U.S.Geological Survey, Open-file Report 98-638, 80 p. [based on Iverson \& (1998); menu-driven ARCINFO GRID software uses DEM] 
Schlager, Wolfgang, and Adams, E.W., 2001, Model for the sigmoidal curvature of submarine slopes: Geology, v. 29, no. 10, p. 883-886. [STRATA pkg. consis. w/ upper-planar / lower-concaveupward model of shelf-slope break]

Schloss, Milton, 1965, Quantifying terrain roughness on lunar and planetary surfaces: American Institute of Aeronautics and Astronautics 2nd Annual Meeting, July 26-29, San Francisco CA, Paper no. 65-389 (separate), 22 p. also abstracted 1966, Journal of Spacecraft and Rockets (AIAA), v. 3, p. 283-285. [PSD-like log-log plots fr slope \& curvature deviations extended to 1.25'grid DEM fr USGS map of Ranger 7 (Mare Cognitum) site]

Schmaltz, Gustav, 1929, Über Glätte und Ebenheit als physikalisches und physiologisches Problem (smoothness \& parallelism as a physical \& physiological problem, in German): Zeitschrift des Vereines deutscher Ingenieure, v. 73, no. 41, p. $1461 \mathrm{ff}$. [engineering-surface measurements fr microscopic study of profile sections]

Schmaltz, Gustav, 1936, Technische Oberflächenkunde-Feingehalt und Eigenschaften von Grenzflächen technischer Körper insbesondere der Maschinenteile (in German; Technical surface science-smoothness \& characteristics of exterior surfaces of workpieces, esp. machine parts): Berlin, Springer Verlag, 286 p. [review of industrial surface metrology, earlier work; profile quantification using the Schmaltz microscope]

Schmid-McGibbon, Gesche, and Eyton, J.R., 1996, Frequency-based contextual landform classification: Geomatica, v. 50, no. 3, p. 287-299. [freq. counts fr. classified DEM's of relief, slope \& curvature]

Schmidt, Jochen, 1996, Untersuchungen zum Einfluß geomorphologischer Variabilität und Struktur auf den Niederschlag-Abfluß-Prozeß in kleinskaligen Einzugsgebieten (in German, Studies on influence of geomorphologic variability \& structure on rainfall-discharge process in small-scale catchments): Ruprecht-Karls-Universität Heidelberg, Geographisches Institut, unpublished Diplomarbeit, 183 p. [hydrologic terrain modelling]

Schmidt, Jochen, and Dikau, Richard, 1999, Extracting geomorphometric attributes and objects from digital elevation models-semantics, methods, future needs, in Dikau, Richard, and Saurer, Helmut, eds., GIS for Earth Surface Systems Analysis and Modelling of the Natural Environment: Stuttgart, Borntraeger, p. 153-173. [overview in GIS context; extends previous work w/ GRASS \& ARC/INFO examples]

Schmidt, Jochen, Hennrich, Kirsten, and Dikau, Richard, 2000, Scales and similarities in runoff processes with respect to geomorphometry: Hydrological Processes, v. 14, nos. 11-12, p. 19631979. [framework overview for detailed work in Schmidt et al. 1998 \& Hennrich et al. 1999]

Schmidt, Jochen, Merz, Bruno, and Dikau, Richard, 1998, Morphological structure and hydrological process modelling: Zeitschrift für Geomorphologie, Supplementband, 112, p. 55-66. [basin morphometry \& rainfall-runoff related using SAKE model]

Schmidt, Jürgen, 2000, Oberflächenabfluß und erosion, Möglichkeiten und Grenzen der mathematischen Prozeßbeschreibung (in German; runoff \& erosion, potentialities \& limitations on math. desc. of process: Zeitschrift für Geomorphologie, Supplementband, 123, p. 1-12. [reviews SLOP 3D, EROSION 2D/3D, RillGrow (Ahnert, etc.); newer models finer scale]

Schmidt, K.M., and Davidson, J.G., 1999, Using geomorphic features to constrain tectonic activity near Pahrump Valley, Nevada and California, in Conference on Status of Geologic Research and Mapping in DeathValley National Park, Las Vegas, NV, April 9-11: U.S. Geological Survey, Openfile report 99-153, p. 154-155. [mountain-front sinuosity, valley H/W, \& drainage area x slope] 
Schmidt, K.M., and Montgomery, D.R., 1996, Rock mass strength assessment for bedrock landsliding: Environmental and Engineering Geoscience, v. 2, no. 3, p. 325-338. [quantifies relief, slope, \& bedding-plane properties]

Schneider, Bernhard, 1995, Adaptive interpolation of digital terrain models, in International Cartographic Conference, 17th, Barcelona, Proceedings: v. 2, p. 2206-2210. [no info; probably like his 1998 work]

Schneider, Bernhard, 1998a, Geomorphologisch plausible Rekonstruktion der digitalen Repräsentation von Geländeoberflächen aus Höhenliniendaten (in German; geomorph. plausible rec. of terrain surfaces fr contour data): Geographisches Institut Universität Zürich, Geoprocessing Reihe, v. 35 (Inaugural dissertation), 226 p. + appendices;

http://www.geo.unizh.ch/ benni/b_3.html. [surface directly fr contours via TIN better than contourto-grid; several applics.]

Schneider, Bernhard, 1998b, Geomorphologically sound reconstruction of digital terrain surfaces from contours, in International Symposium on Spatial Data Handling 8th, 11-15 July, Vancouver BC, Proceedings: p. 657-667. [thesis work; gets surface directly from contours via TIN; several applics]

Schneider, Bernhard, 2000, Uncertainty propagation in digital terrain modelling with Taylor methods and interval arithmetic, in Accuracy 2000, July 2000, Amsterdam, Proceedings: p. 561-568. [no info]

Schneider, Bernhard, 2001, Phenomenon-based specification of the digital representation of terrain surfaces: Transactions on GIS, v. 5, no. 1, p. 39-52. [no info]

Schneider, Bernhard, 2001, Uncertainty of local form in digital terrain modelling (extd. abs.), in GIS Research UK 9th Annual Conference (GISRUK 2001), Proceedings: p. 336-340. [no info]

Schneider, Bernhard, and Martinoni, Daria, 2001, A distributed geoprocessing concept for enhancing terrain analysis for environmental modeling: Transactions on GIS, v. 5, no. 2, p. 166-178. [no info]

Schneider, Hans, 1932, Maximal Reliefenergie, in Morphologie des Buntsandsteinodenwaldes: Frankf. Geogr., v. 6, no. 2, plate 6, 1/800K map. [map of relief 'energy' on 5km squares; 7 relative-relief intervals]

Schoorl, J.M., Sonneveld, M.P.W., and Veldkamp, A., 2000, Three-dimensional landscape process modelling - the effect of DEM resolution: Earth Surface Processes and Landforms: v. 25, no. 9, p. 1025-1034. [5 DEM spacings for hillslope \& basin; erosion \& sedimentation rates over- \& underpred.]

Schörghofer, Norbert, and Rothman D.H., 2001, Basins of attraction on random topography: Physical Review E, v. 63 , no. 2, p. 132-137. [ability to collect water $\approx$ contour curv. / local slope, so hillslope \& drainage area statistically related, even in random topography; Gaussian surfaces model random topography]

Schrepfer, Hans, 1933, Karte (2) der Reliefenergie, in Der Kaiserstuhl: Bad. Landeresverein f. Naturkunde und Naturschutz, Freiburg i B., p. 5, 1/133K map, and p. 7, 1/120K map (Taleintiefung). [maps of relief 'energy'; resp. 7 and 4 relative-relief intervals]

Schröder, Florian, and Roßbach, Patrick, 1994, Managing the complexity of digital terrain models: Computers and Graphics, v. 18, no. 6, p. 775-783. [create TINs from DEMs (an off-line process, due to its complexity)] 
Schroeder, Martin, 1995, Computergestützte Reliefmodellierung der Erde (in German, computerassisted relief modelling of the Earth): Diplomarbeit im Fach Geographie, Ruprecht-Karls Univ. Heidelberg, Fakultät für Geowissenschaften Geographisches Institut, 84 p. and 4 fold-out color maps. [Hammond classif. of New Mexico, US (lower 48), \& world (GTOPO30)]

Schruben, P.G., 1998, Color shaded-relief map of the conterminous United States: U.S. Geological Survey, Open-file Report 99-0011, CD-ROM (ESRI ArcView 3.0 reqd.), and http://pubs.usgs.gov/openfile/of99-011/ (Adobe Photoshop reqd.). [15 arc-sec fr. old Arny data; uses Mark's multi-directional shading]

Schuller, D.J., Rao, A.R., and Jeong, G.D., 2001, Fractal characteristics of dense stream networks: Journal of Hydrology, v. 243, nos. 1-2, p. 1-16. [self-affine, not self-similar; $\boldsymbol{D}$ varies widely by technique]

Schultze, C., 1864, Flächeninhalt und Küstenlänge. Notiz, betr. den Schumannschen Vorschlag. (Area \& coastal length. Note, Schumann's suggestion considered, in German): Petermanns Geogr. Mitteilungen, v. 10, no. 3, p. 92. [the area/perimeter problem; 'coast devel.' $=U / K, U=$ coast length, for K see Rohrbach, 1890]

Schulz, Karsten, Huwe, Bernd, Wörlen, Christine, and Eiden, Reiner, 1999, Wind speed regionalization and its influence on areal evapotranspiration prediction, in Diekkrüger, Bernd, Kirkby, M.J., and Schröder, Ulrich, eds., Regionalization in Hydrology: Conference, Technical University of Braunschweig, Germany, 10-14 March, 1997, Proceedings: IAHS Publication no. 254, p. 97-104. [distributed DEM data much improve ET estimates over those based on central station topo only]

Schumann, Dr., 1864, comments (in German) in Bothe (1864a), p. $406 . \quad$ [the area/perimeter problem; 'coastal development' $=U / 2 \sqrt{F} \Pi: U=$ perimeter of coast, $F=$ area enclosed; and $r 1=$ $\sqrt{ } \mathrm{F} / \Pi$; see Rohrbach, 1890]

Schumm, S.A., 1954, Evolution of drainage systems and slopes in badlands at Perth Amboy, New Jersey: Office of Naval Research Project no. 389-042, Contract N6 ONR 271-30, Technical Report no. 8, New York, Columbia University, Department of Geology, 86 p. + illustrations. [most prominent Strahler student; extended Horton work on topologic \& geometric variables]

Schumm, S.A., 1954, The relation of drainage basin relief to sediment loss, in International Association of Hydrology, IUGG, General Asembly 10th, Rome, Proceedings: v. 1, p. 216-219. [defined relief ratio, $\mathrm{Rh}$, as total basin relief / max. basin length parallel to main trunk]

Schwartz, P.M., Levine, D.A., Hunsaker, C.T., and Timmins, S.P., 1995, TERRAIN, a computer program to process digital elevation models for modeling surface flow: U.S. Department of Energy, National Laboratories, Oak Ridge TN, 73 p. [software calculates overland flow paths, watershed boundaries, slope, \& aspect; US\$22.95]

Scott, P.J., 2001, An algorithm to extract critical points from lattice height data: International Journal of Machine Tools and Manufacture, v. 41, Nos. 13-14, p. 1889-1897. [satisfies Euler Criterion \& other topological properties that always must apply to continuous data]

Seibert, Jan, 1999, On TOPMODEL's ability to simulate groundwater dynamics, in Diekkrüger, Bernd, Kirkby, M.J., and Schröder, Ulrich, eds., Regionalization in Hydrology: Conference, Technical University of Braunschweig, Germany, 10-14 March, 1997, Proceedings: IAHS Publication no. 254, p. 211-220. [basic assumptions obstruct correct simulation of spatial \& temporal dynamics]

Serra, Jean, 1995, (online) Course on mathematical morphology: Centre de Morphologie Mathématique, Fontainebleau, France. <http://cmm.ensmp.fr/ serra/cours.htm>. [chapter 9, 'Skiz and Watershed', describes grey scale-to-elevation transformation; standard text on subject = Serra Jean, 1982, Image Analysis and Mathematical Morphology: London, Academic Press] 
Serrat, Joan, López, A.M., and Lloret, David, 2000, On ridges and valleys, in International Conference on Computer Vision 15th (ICPR'00), IEEE Computer Society, 3-8 September, Barcelona: Proceedings, v. 4, p. 59-66. [intro. to descriptive geometry of ridges \& drains in machine vision; taxonomy; see López 1997 \& 1999]

Seymour, M., and Cumming, I., 1998, Improving DEMs using SAR interferometry, in IEEE International Geoscience and Remore Sensing symposium (IGARSS), Seattle WA, July 6-10, Proceedings: Piscataway NJ, Institute of Electrical and Electronic Engineers, CD-ROM. [work with GTOPO30]

Sharma, H.S., 1986, Climate and drainage basin morphometric properties - a case study of Rajasthan, in Gardiner, V., ed., International Geomorphology 1986, Part II: New York, John Wiley \& Sons, p. 69-87. [maps of stream freq. \& dissection index; 5 climate types contrasted]

Sharpton, V.L., and Head, J.W. III, 1985, Analysis of regional slope characteristics on Venus and Earth: Journal of Geophysical Research, v. 90, no. B5, p. 3733-3740. [Pioneer/Venus data; $3^{\circ} \times 3^{\circ}$ samples; same range, diff. freq. distr.]

Shary, P.A., 2001, Analytical GIS "Eco": <http://members.fortunecity.com/eco4/giseco/>. [software package for digital terrain modeling \& display, by Peter Shary, for Windows 95/98/2000/NT; 23 land surface attributes; $\$$ US $900 / 1200$ as of $05 / 02$; emphasis on soils analysis by the curvature measures in Shary 1995 \& Shary et al. 2002]

Shary, P.A., Sharyara, L.S., and Mitusov, A.V., 2002, Fundamental quantitative methods of land surface analysis: Geoderma, v. 107, nos. 1-2, p. 1-32. [DEM-based random-field parameterization of surface curvature after Gauss 1827, Evans \& Young 1978, Krcho 1973 \& 83; formulae for 12 curvatures \& 7 other local parameters]

Shepard, F.P., 1970, Lagoonal topography of Caroline and Marshall Islands: Geological Society of America Bulletin, v. 81, no. 7, p. 1905-1914. [4-fa contours reveal irreg. floors; 10-20-m-relief knoll-\&-basin topo]

Shiiba, Michiharu, Ichikawa, Yutaka, Sakakibara, Tetsuyoshi, and Tachikawa, Yasuto, 1999, A new numerical representation form of basin topography (in Japanese with English abstract \& figure captions): Transactions of the Japanese Society of Civil Engineers, n. 621/II-47, p. 1-9. [gets both concentration \& divergence of flow fr grid DEM]

Shimazu, Hiroshi, 2001, Relief condition and sediment transport processes in Japanese and Korean mountain river basins: Transactions of the Japanese Geomorphological Union, v. 22, no. 3, p. 307320. [R/elev., R components by river type; elev. \& slope/stream distance]

Shinagawa, Yoshihisa, and Kunii, T.L., 1991, Constructing a Reeb graph automatically from cross sections: IEEE Computer Graphics and Applications, v. 11, no. 6, p. 44-51. [topological skeleton of 3-D object from surface contours]

Shinagawa, Yoshihisa, Kunii, T.L., and Kergosien, Y.L., 1991, Surface coding based on Morse theory: IEEE Computer Graphics and Applications, v. 11, no. 5, p. 66-78. [extends Morse theory (for abstracting shape of a surface) to sections of 3-D objects]

Shinagawa, Yoshihisa, Kunii, T.L., Belyaev, A.G., and Tsukioka, Taketo, 1996, Shape modeling and shape analysis based on singularities: The International Journal of Shape Modeling, v. 2, no. 1, p. 85-102. [define fcn. on object \& use its singularities to abstract object shape; Reeb graph, wavelets]

Shortridge, A.M., 1997, Characterizing the relationship between $7.5^{\prime}$ and 1 degree digital elevation models: Santa Barbara, University of California, M.A. thesis, 70 p. [the "old Army" 1 degree data are poor by comparison] 
Shortridge, A.M., 2001, Characterizing uncertainty in digital elevation models: ch. 11, in Hunsaker, C.T., Goodchild, M.F., Friedl, M.A., Case, T.J., eds., Spatial Uncertainty in Ecology-Implications for Remote Sensing and GIS Applications: New York, Springer, p. 238-257. [2 causes; diffs. betw. data model \& real surface, and poor capture by production methods]

Shortridge, A.M., and Clarke, K.C., 1999, On some limitations of square raster cell structures for digital elevation data modeling, Ch. 41 in Lowell, Kim, and Jaton, Annick, eds., Spatial Accuracy Assessment-Land Information Uncertainty in Natural Resources: Chelsea, MI, Ann Arbor Press, p. 341-347. [identified resampling problems that need to be addressed by GIS users]

Shrestha, R.L., and Carter, W.E., 2000, Bare earth digital terrain model from airborne laser swath mapping (abs.): Eos Transactions of the American Geophysical Union, v. 81, no. 48 (Supplement, G72A-01), p. F323. ['ground clutter' (structures, vegetation, etc.) filtered out of DEMs]

Shreve, R.L., 1963, Horton's "Law" of stream numbers for topologically random drainage netwirks (abs.): Transactions, American Geophysical Union, v. 44, no. 1, p. 44-45. [1st publ. by Shreve on randomness, rather than orderly development, in river patterns]

Shreve, R.L., 1974, Variation of main stream length with basin area in river networks: Water Resources Research, v. 10, no. 6, p. 1167-1177. [Systematic deviation of observations ( $\mathrm{n}=461)$ from Hack's Law]

Shulits, Samuel, 1955, Graphical analysis of trend profile of a shortened section of river: Transactions of the American Geophysical Union, v. 36, no. 4, p. 649-654. [cutoffs on the Rhine; slope \& sediment size closely related]

Siakeu, Jean, and Oguchi, Takashi, 2000, Soil erosion analysis and modelling-a review: Transactions, Japanese Geomorphological Union, v. 21, no. 4, p. 413-429. [USLE \& alternatives; includes caveats on DEM-based work]

Siegburg, Werner, 1987, Talasymetrien in der Umgebung von Bonn (Valley symmetry around Bonn): Decheniana, v. 140, p. 204-217. [no info]

Siegburg, Werner, 1988, Multivariate statistische Untersuchungen zur Hanggenese am Beispiel des Siebengebirges (multivariate statistical studies of slope genesis exemplified by the Sieben mountains): Zeitschrift für Geomorphologie, v. 32, no. 4, p. 481-497. [correl. slope, conc., conv. w/ geology, aspect, sed. cover, etc.]

Siegmund, Mike, and Hall, Kevin, 2000, A study of valley-side slope asymmetry based on the application of GIS analysis-Alexander Island, Antacrtica: Antarctic Science, v. 12, no. 4, p. 471476. [slope \& aspect of polygons of TIN-DEM fr map contours]

Sigle, M., 1985, Das digitale Höhenmodell für das Land Baden-Württemberg (in German): Nachr. Karten-und Vermessungswesen, Series I, v. 95, p. 143-154. [the Baden-Württemberg provincial DEM]

Sigle, M., Hellwich, O., and Köstli, A., 1992, Intersection and combination of digital elevation models-methods and applications: International Archives of Photogrammetry and Remote Sensing, v. 29, pt. B4, Commission IV, p. 878-882. [DEM analysis pkg SCOP]

Simonett, D.S., 1967, Landslide distribution and earthquakes in the Bewani and Torricelli Mountains, New Guinea, a statistical analysis, in Jennings, J.N., and Mabbutt, J.A., eds., Landform Studies from Australia and New Guinea: Canberra, Australian National University Press, p. 64-84. [L/S elev., slope angle \& length, area, vol.; mult. regression eqns.; denudation est.]

Singh, R.L., 1967, Morphometric analysis of terrain, Part 2: Indian Sci. Congr. Ass., 54th Sess., Proc. p. 115-134. [Relative relief, dissection indexes, drainage texture or density, slope] 
Sinha-Roy, S., 2002, Hypsometry and landform evolution-a case study in the Banas drainage basin, Rajasthan, with implications for Aravalli uplift: Journal of the Geological Society of India, v. 60 , no. 1 , p. 7-26. [10 basins; tectonic history interpr. fr shape of $\%$ hypsom. curves $\&$ relation to several other basin measures]

Sirotkin, M.P., 1961, Calculation of topographic volume by approximate integration techniques (in Russian): Izvestiya Vysshikh Uchebnyh Zavedeny, Geodesiya i Aerophotosyemka, no. 6, p. 39-46. [no info]

Sitnikov, V.K., 1964, Calculation of mean river slope and valley side slope (in Russian): Meteorol. Gidrol., no. 3, paging unknown. [no info]

Sivapalan, M., Jothityangkoon, C., and Menabde, M., 2002, Linearity and nonlinearity of basin response as a function of scale-discussion of alternative definitions: Water Resources Research, v. 38 , no. 2, p. 4-1 to 4-5. [Hack's law arises from linear network response \& a purely geometrical property of the basin]

Sjogren, D.B., and Rains, R.B., 1995, Glaciofluvial erosional morphology and sediments of the Coronation-Spondin Scabland, east-central Canada: Canadian Journal of Earth Science, v. 32, no. 5 , p. 565-578. [1/20K DEMs \& altimetric surveys of v. low-relief features; $1-2-\mathrm{m} \mathrm{Cl}$ ]

Skempton, A.W., 1953, Soil mechanics in relation to geology: Proceedings of the Yorkshire Geological Society, v. 29, pt. 1, no. 3, p. 33-62. [1st distinction of landslides by D/L, where D= depth of moving mass \& L= length upslope; also slope gradient vs. slope height]

Skidmore, A.K., 1997, GIS applications and use of digital terrain modelling, in Hodgson, S., Rumor, and Harts, J.J., eds., Joint European Conference on Geographical Information, 3rd, Vienna, Austria, Proceedings: Amsterdam, IOS Press, v. 1, p. 442-463. [reviews DEM's in GIS; DEM accuracy, quality, role in modeling; big biblio heavy on applic.]

Skinner, H., and Moore, A.J., 1997, Digital elevation model of the Oak Ridges Moraine, southern Ontario (hillshade enhanced): Geological Survey of Canada, Open-File Report 3297, 1 poster. [Oak Ridges Moraine NATMAP Project; see Kenny 1998 \& Kenney et al. 1999]

Slatton, K.C., Crawford, M.M., and Evans, B.L., 2001, Fusing interferometric radar and laser altimeter data to estimate surface topography and vegetation heights: IEEE Transactions on Geoscience and Remote Sensing, v. 39, no. 11, p. 2470-2482. [one way to get accurate, dense, and broad coverage]

Small, D., 1998, Generation of Digital elevation Models Through Spaceborne SAR Interferometry: Department of Geography, Univ. Zurich, Remote Sensing Series, v. 30, 150 p. [hybrid text/Ph.D. thesis; thorough on DEM analysis fr. 2 test areas]

Small, Christopher, and Cohen, J.E., 1999, Continental physiography, climate and the global distribution of human population, in International Symposium on Digital Earth, Beijing, Proceedings: Beijing, China, Science Press, p. 965-971; http://www.Ideo.columbia.edu/ small/population.html. [graphs show how world pop. density diminishes rapidly w/ elev. \& distance fr sea \& permanent rivers]

Smalley, I.J., and Unwin, D.J., 1968, The formation and shape of drumlins and their distribution and orientation in drumlin fields: Journal of Glaciology, v. 7, p. 377-390. [applied nearest-neighbor test]

Smart, J.S., 1972, Channel networks: Advances in Hydroscience, v. 8, p. 305-346. [Melton's law: channel freq./sq (ch. density) $\approx 0.69$ ] 
Smart, J.S., 1973, The random model in fluvial geomorphology, in Morisawa, M.E., ed., Fluvial Geomorphology, in annual geomorphology symposium, 4th, Binghamton, N.Y., SUNY, Proceedings: Publications in Geomorphology, p. 27-49. [introduces 3rd postulate to Shreve's 2; finds topol. random model better than Horton's laws]

Smith, D.D., and Whitt, D.M., 1948, Evaluating soil losses from field areas: Agricultural Engineering, v. 29 , no. 9, p. 394-396. [derived eqn for soil loss (corn-belt slope-practice); uses data fr. uniform slopes]

Smith, D.E., Zuber, M.T., and 17 others, 1999, The global topography of Mars and implications for surface evolution: Science, v. 284, no. 5419, p. 1495-1503. [26-million-elev MOLA DEM at $1^{\circ}$ $(\sim 59 \mathrm{~km})$ res. \& $\pm 13-\mathrm{m}$ accuracy]

Smith, D.E., Zuber, M.T., and 22 others, 2001, Mars Orbiter Laser Altimeter-experiment summary after the first year of global mapping of Mars: Journal of Geophysical Research, v. 106, no. E10, p. 23,689-23,722. [Sect. 8, misc. topo. results; regional elev, slope; crater d/D; volc. relief \& vol.; 5 Ig drainage basins]

Smith, K.G. 1958, Erosional processes and landforms in Badlands National Monument, South Dakota: Bulletin of the Geological Society of America, v. 69, no. 8, p. 1975-1008. [results on topo. texture, bifurcation ratios, \& statistics of slope length \& gradient in p. 998-1006]

Smith, L.C., 2002, Emerging applications of interferometric synthetic aperture radar (InSAR) in geomorphology and hydrology: Annals of the Association of American Geographers, v. 92, no. 3, p. 385-398. [applics underdeveloped in geography; review \& good biblio]

Snyder, N.P., Whipple, K.X., Tucker, G.E., and Merritts, D.J., 2000, Landscape response to tectonic forcing-digital elevation model analysis of stream profiles in the Mendocino triple junction region, northern California: Geological Society of America Bulletin. v. 112, no. 8, p. 1250-1263. [DEM slope-area of 21 channels; profile concavity constant]

Sobolev, S.S., 1936, Map of erosion depth in the Ukranian SSR and related problems (in Russian): Problemy sovetskogo pochvovedeniya, no. 1: Moscow-Leningrad, AN SSSR, paging unknown. [no info]

Sobolev, S.S., 1948, Development and Control of Erosion Processes in the European Part of the USSR, v. 1: Soviet Academic Press, Moscow, 307 p. [no info]

Soille, Pierre, 1988, Modèles numériques de terrain et morphologie mathématique-délimitation automatique de bassins versants (in French): Mémoire de fin d'études (Master's Thesis), Louvain-laNeuve, Belgium, Université catholique de Louvain, paging unknown. [DEM's-to-watershed using mathematical morphology]

Soille, Pierre, 1989, Modèles numériques de terrain et morphologie mathématique-délimitation automatique de bassins versants (in French): 2èmes Journées Utilités et Limites des Modèles en Hydrologie, Montpellier, ORSTOM, p. 12-13. [DEM's-to-watersheds]

Soille, Pierre, 1990, Génération de MNT à partir de fonctions distances (in French): 3èmes Journées Utilités et Limites des Modèles en Hydrologie, Montpellier, ORSTOM, p. 1-14. [DEM work; no other info]

Soille, Pierre, 1999, Morphological Image Analysis: Berlin, Springer-Verlag, 316 p. (English edition of Morphologische Bildverarbeitung, 1998). [math. morphology; a few DEM applics.; p. 230-39, 'the watershed transformation' (grey scale to elevation)] 
Soille, Pierre, 1999, Processing of digital elevation maps, Chapter 19 in Jähne, B., Haußecker, H., and Geißler, P., eds., Handbook of Computer Vision and Applications, v. 3: San Diego, Academic Press, p. 411-428. [no info; see other articles]

Soille, Pierre, 2002, Advances in the analysis of topographic features on discrete images: Lecture Notes in Computer Science, no. 2301, p. 175-186. [math. morphology; imposition of minima, lower complete transf., hit-or-miss transform, extracting crest lines by skeletonisation]

Soille, Pierre, and Gratin, C., 1994, An efficient algorithm for drainage networks extraction on DEMs: Journal of Visual Communication and Image Representation, v. 5, no. 2, p. 181-189. [improved DEM-to-watershed transformation]

Soille, Pierre, Nickolay, B., and Köppen, M., 1994, A modular system for image segmentation based on watershed transformation: Vision Magazine, v. 94, no. 2, p. 118-120. [mathematical morphology, the grey scale-to-'watershed' transformation]

Sokolov, A.A., 1962, Interrelations between the morphological features of basins and of river networks (in Russian): Meteorol. Gidrol., no. 2, paging unknown. [no info]

Sokolov, A.A., 1969, Interrelationship between geomorphological characteristics of a drainage basin and stream (in Russian): Soviet Hydrology, Selected Papers, no. 1, paging unknown. [no info]

Sonklar, C.E. von I., 1860, Die Oetzthaler Gebirgsgruppe, mit besonderer Rücksicht auf Orographie und Gletscherkunde, nach eigenen Untersuchungen dargestellte (in German): Gotha, J. Perthes, $306 \mathrm{p}$. [1st use of some of the morphometric measures (pp. $249 \mathrm{ff}$.) summarized in full later in his 1873 book (not known if term 'orometrie' coined here); 13 maps]

Sonklar, C.E. von I., 1862, Die Gebirgsgruppe der Hohen Tatra (in German): Petermanns Geographischen Mitteilungen, v. 8, no. 4, p. 121-125. [compares Ötzthaler Alps \& Hohen Tatra across 7 of the 12 parameters later summarized in 1873 book]

Sonklar, C.E. von I., 1866, Die Gebirgsgruppe der Hohen-Tauern, mit besonderer Rücksicht auf Orographie, Gletscherkunde, Geologie und Meteorologie, nach eigenen Untersuchungen dargestellt (in German): Vienna, Beck'sche Universitäts-Buchhandlung, 408 p. [Pt. 1, Orographie, Orometrie, Topographie; further use of some of the morphometric measures later summarized in his 1873 book]

Sonklar, C.E. von I., 1872, Die Zillerthaler Alpen, mit besonderer rücksicht auf orographie, gletscherkunde und geologie nach eigenen untersuchungen dargestellt (in German): Gotha, Justus Perthes, Ergänzungsheft (supplement volume) no. 32, to Petermanns Geographischen Mitteilungen, 61 p. [many mean heights of ridges \& other forms in chap. VI-VII, pp. 39-54ff.]

Sowter, M.J., and Talling, P.J., 1998, Topographic fingerprinting of erosional processes in mountainous regions (abs.): Eos, Transactions of the American Geophysical Union, v. 79, no. 45, supplement, p. F366. [suite of DEM params. ; relief, slope, plan. arrangement of ridges, valleys, spurs]

Sparks, B.W., 1949, The denudation chronology of the dip-slope of the South Downs: Proceedings of the Geologists' Association, v. 60, no. 3, p. 165-215. [devised the height-range diagram; plotted 283 field-surveyed flat areas]

Sparks, B.W., 1952, Stages in the physical evolution of the Weymouth Lowland: Transactions and Papers of the Institute of British Geographers, no. 18, p. $21 . \quad$ [elaborated the height-range diagram of Sparks 1949] 
Speckmann, Bettina, and Snoeyink, Jack, 2001, Easy triangle strips for TIN terrain models: International Journal of Geographical Information Science, v. 15, no. 4, p. 379-386. [spanning trees based on visibility $=$ simple $\&$ effective way to get strips]

Spinney, Jamie, 2001, Environmental Application of LIDAR Data-Exploring High-Resolution Watershed Delineation: Lawrencetown, NS, Nova Scotia Community College, Centre of Geographic Sciences (COGS), Applied Geomatics Research Group, report; http://142.227.25.130:8787/agrg/reports/lidar_watersheds.pdf; slide presentation at http://142.227.25.130:8787/agrg/presentations/pdf/Watersheds.pdf. [feasibility study, compare w map data; used Arc/Info AML; LIDAR has both +\&-s]

Squividant, E., 1994, MNTsurf, logiciel de traitment des Modèles Numérique de Terrain: Rennes, ENSAR (Ecole Nationale Supérieure Agronomique de Rennes), internal document, paging unknown. [calculates such hydro parameters as catchment area]

Srinivasan, Raghavan, and Engel, B.A., 1991, Effect of slope prediction methods on slope and erosion estimates: Applied Engineering in Agriculture, v. 7, no. 6, p. 779-783. [compared 4 square-grid-DEM slope-calc. techniques against field meas.; found neighborhood \& quadratic best. \& max. slope poorest]

Srinivasan, Raghavan, Engel, B.A., Wright, J.R., Lee, J.G., and Jones, D.D., 1994, The impact of GIS-derived topographic attributes on the simulation of erosion using AGNPS: Applied Engineering in Agriculture, v. 10, no. 4, p. 561-566. [refinement of their 1991 experiment; neighborhood method best]

Stange, Paul, 1885, Orometrie des Thüringerwaldes (in German): Friedrichs-Universität HalleWittenberg, Inaugural-Dissertation (Ph.D.), 44 p.; also 1885, in Petermanns Geographische Mitteilungen, v. 31, no. 7?, p. 250-254. [Sonklar's volume method for mountains = mean dimensions for Thur. Forest block; 12 meas. for 36 valleys, $17 \mathrm{~N} \& 19 \mathrm{SW}$ (sloping?)]

Stark, C.P., and Hovius, Niels, 2001, The characterization of landslide size distributions: Geophysical Research Letters, v. 28, no. 6, p. 1091-1094. [power-law scaling, but small failures are strongly undersampled]

Stark, C.P., and Stark, G.J., 2001, A channelization model of landscape evolution, in Pazzaglia, F.J., and Knuepfer, P.L.K., eds., The steady-state orogen-concepts, field observations, and models: American Journal of Science, v. 302, nos. 4 \& 5, p. 486-512. [sub-grid scale parameterization aggregates channel properties of roughness, srfce morph., cross-sect.]

Steger, Carsten, 1997, Removing the bias from line detection in CVPR '97, IEEE International Conference on Computer Vision and Pattern Recognition, 17-19 June, Puerto Rico, Proceedings: p. 116-122. [develops explicit model for surroundings of curvilinear structures ('lines') as well as lines themselves]

Steger, Carsten, 1998, An unbiased detector of curvilinear structures: IEEE Transactions on Pattern Analysis and Machine Intelligence, v. 20, no. 2, p. 113-125. [similar to Steger 1997 (\& unpubl. 1997 Ph.D. dissertation)]

Steger, Carsten, 1999, Subpixel-precise extraction of watersheds, in IEEE International Conference on Computer Vision 7th (ICCV'99), 20-25 September, Corfu, Greece, Proceedings (CD-ROM): p. 884-890. [critical points \& flowlines fr Gaussian filter derivatives superior to pixel-by-pixel routing]

Steiner, N., Harder, M., and Lemke, P., 1999, Modelling sea ice roughness in the Arctic, in Wettlaufer, J.S., Dash, J.G., and Untersteiner, Norbert, eds., Ice Physics and the Natural Environment: NATO ASI Series (1997 meeting), v. I 56, Berlin, Springer, p. 341-345. [model fr statistics of observed pressure-ridge geometry; use to verify remote sensing] 
Steinhauser, Dr., 1864, comments (in German) in Bothe (1864a), p. $406 . \quad$ [the area/perimeter problem; 'coastal convolution' $=\left((\mathrm{U} / 4)^{2}\right) / \mathrm{F}, \mathrm{U}=$ coast length, $\mathrm{F}=$ land area]

Stelford, Mark, 1998, Sources of error in morphometrically defined hydrologic source areas (abs.), in Hallam, C.A., and Salisbury, J.M., eds., GIS Applications in Water Resources Research-American water Resources Annual Meeting, Chicago III, November 6-10, 1994: U.S. Geological Survey, Open-file Report 98-751, p. $19 . \quad$ [problem = 'sinks' in glaciated \& karst terrain on 7.5' DEM's not real]

Stepinsky, T.F., Marinova, M.M., McGovern, P.J., and Clifford, S.M., 2002, Fractal analysis of drainage basins on Mars: Geophysical Research Letters, v. 29, no. 8, p. 30-1 to 30-4. [4-point network descriptor fr Tarboton algorithm on $0.5 \mathrm{~km}$ DEMs of old mtn. terrain fr MOLA data]

Sternberg, H., 1875, Untersuchungen über Längen- und Querprofil geschiebeführender Fluss (study of the longitudinal \& transverse profile of the most (?) prominent river; in German): Zeitschrift für Bauwesen, v. 25, no. 11-12, p. 483-506. [the Rhine; 1st to suggest long. profile = exponential curve; related slope to sediment size—see Gilbert 1877]

Stevens, N.F., Wadge, G., and Murray, J.B., 1999, Lava flow volume and morphology from digitised contour maps-a case study at Mount Etna, Sicily: Geomorphology, v. 28, nos. 3-4, p. 251-261. [differences 10-m DEM's fr 1969 \& 1991 1/25K maps, 25-m Cl; not OK for thin flows]

Stewart, E.M., and Head, J.W., 2001, Ancient Martian volcanoes in the Aeolis region-new evidence from MOLA data: Journal of Geophysical Research, v. 106, no. E8, p. 17,505-17,513. [parabolic curves fit to flank topo. of candidate stratocone MOLA 'Feature $A^{\prime}$ suggest original $\mathrm{h} \sim 3 \mathrm{~km}$ ]

Stewart, lan, 1991, A Swift trip over rugged terrain: Scientific American, v. 264, no. 6, p. 123-125. ['critical points' theorem; $\mathrm{H}+\mathrm{V}-\mathrm{P}=2$, where $\mathrm{H}=$ no. of local maxima, $\mathrm{V}=$ min., $\mathrm{P}=$ saddles]

Stocks, J., 1939, Neues zur Morphometrie des Atlantischen Ozeans: Annaler der Hydrographie und Maritimen Meteorology, v. 67, p. 1-13. [see Stocks, 1938; (NB, author's initial Th.?)]

Stoddard, P.R., and Jurdy, D.M., 2002, Distribution of lo's volcanoes-possible influence on spin axis: Geophysical Research Letters, v. 29, no. 9, 10.1029/2001GL014539, p. 63-1 to 63-4. volcanoes $\& \sim 100$ mountains are complementary re longitude]

Stoddart, D.R., ed., 1997, Process and Form in Geomorphology: London \& NY, Routledge, 415 p. [not seen; the Chorley Festschrift; a few papers appear to be morphometric]

Stokes, S., Goudie, A.S., Ballard, J., Gifford, C., Samieh, S., Embabi, N., and El-Rashidi, O.A., 1999, Accurate displacement and morphometric data using kinematic GPS: Zeitschrift für Geomorphologie, Supplementband 116, p. 195-214. [h/W data on 20 barchans in SW Egypt]

Stout, K.J., and others, 1999, $14(+3)$ parameters for 3D surface roughness: University of Huddersfield, UK, School of Engineering, Center for Ultra Precision Techniques, $<$ http://zeus.plmsc.psu.edu/ manias/MatSc597/roughness/definitions.html>. [details on industrial morphometric measures on Web; see Stout et al., 1993, 2000]

Stout, K.J., and Blunt, Liam, eds., 2000, Three-Dimensional Surface Topography (2nd Ed): London UK and Bristol PA, Penton Press, 308 p. [enlarged ed. of state-of-art review of a major development in metrology]

Stout, K.J., Blunt, Liam, Dong, W.P., Mainsah, Evaristus, Luo, N., Mathia, T.G, Sullivan, P.J., and Zahouani, H., 2000, The development of methods for the characterisation of roughness in three dimensions (2nd ed.): London UK and Bristol PA, Penton Press, 384 p. [revision \& enlargement of important 1993 review] 
Stover, J.C., 1995, Optical Scattering-Measurement and Analysis, 2nd ed.: SPIE Press, Bellingham WA, 340 p. [full description of power spectral density applied to optical micro-surfaces]

Strahler, A.N., 1952, Dynamic basis of geomorphology: Bulletin of the Geological Society of America, v. 63 , no. 9, p. 923-938. [mechanics \& fluid dynamnics; 1st mention of general systems theory in geomorph.]

Strahler, A.N., 1954, Quantitative geomorphology of erosional landscapes: 19th International Geological Congress, Algiers, 1952, Comptes Rendues, Section 13, part 3, fasc. 15, p. 341-354. [good summary \& intro to the subject]

Strahler, A.N., 1956, The nature of induced erosion and aggradation, in Thomas, W.L., Jr., ed., Man's Role in Changing the Face of the Earth: University of Chicago Press, p. 621-638. [introduces 'Horton Number' = runoff intensity + slope + 'erosion porportionality']

Strahler, A.N., 1958, Dimensional analysis applied to fluvially eroded landforms: Bulletin of the Geological Society of America, v. 69, no. 3, p. 279-300. [parameter lists; methodol. statements; descr. of optimal analytic procedures]

Strahler, A.N., 1968, Quantitative geomorphology, in Fairbridge, R.W., ed., The Encyclopedia of Geomorphology, New York, Reinhold, p. 898-912. [his last state-of-art summary of HortonStrahler geomorph.; modified from Strahler 1964]

Streit, Ulrich, Fuhrmann, Sven, Krause, Joachim, and Mittring, Peter, 1999, GIS for regionalization and visualization in hydrology, in Diekkrüger, Bernd, Kirkby, M.J., and Schröder, Ulrich, eds., Regionalization in Hydrology: Conference, Technical University of Braunschweig, Germany, 10-14 March, 1997, Proceedings: IAHS Publication no. 254, p. 253-258. [flow-direction applic. of 'Tools for Hydro. Info. \& Modelling', T4HIM, in ARC/INFO]

Strumbo, D.A.,1963, Surface texture-measurement methods: Forest Products Journal, v. 12, no. 7 , p. 299-303. [early surface-roughness analysis on wood]

Struzik, Z.R., 1996, From coastline length to inverse fractal problem-the concept of fractal metrology: University of Amsterdam, Neth., unpublished Ph.D. dissertation, paging unnown. [continued development of the wavelet transform; highly mathematical]

Sulebak, J.R., 1997, Geomorphometric studies of different topographic regions-analysis and applications from Norway and Sweden: University of Oslo, Department of Geography, Sc.D. thesis, 204 p. [see Sulebak 1999 \& Sulebak et al. 1997]

Sulebak, J.R., 1999, Fractal analysis of surface topography: Norsk Geografisk Tidsskrift (Norwegian Journal of Geography), v. 53, no. 4, p. 213-225. [topo. scaling; 50m DEM; multiple PSD of 2 areas: not unifractal; good biblio]

Sulebak, J.R., Tallaksen, L.M., and Erichsen, B., 2000, Estimation of areal soil moisture by use of terrain data: Geografiska Annaler, v. 82A, no. 1, p. 89-105. [slope, aspect, plan \& profile curv., \& wetness index fr 5m DEM; regression model]

Summerfield, M.A., 1976, Slope form and basal stream relationships-a case study in the Westend basin of the southern Pennines, England: Earth Surface Processes, v. 1, no. 1, p. 89-96. [54 field slope-profiles at 5-m segments, convexity index]

Summerfield, M.A., 1991, Sub-aerial denudation of passive margins-regional elevation versus local relief models: Earth and Planetary Science Letters, v. 102, no. 3/4, p. 460-469. [slope/modal elev. \& slope/relief fr 1/250K map 15' DEM] 
Sun, Tao, Meakin, Paul, and Jøssang, Torstein, 2001, A computer model for meandering rivers with multiple bed load sediment sizes, 1, Theory, 2, Computer simulations: Water Resources Research, v. 37 , no. 8 , p. $2227-2241 \& 2243-2258$. [parameter space has 5 geomorph. regions; initial meander is growth controlled by curvature-related instabilities]

Sung, Q.C., Chan, Y.C., and Chao, P.C., 1998, Spatial variation of fractal parameters and its geological implications: Terrestrial, Atmosphere and Oceanic Sciences (TAOS; Taiwan), v. 9, no. 4, p. 655-672. [includes an azimuth-related parameter]

Surell, Alexandre, 1841, Étude sue les torrents des Hautes-Alpes: Paris, Carilian-Goeury and V. Dalmont, 283 p. [his régime = 'grade', concept of a limiting slope for fluvial transport; meas. long. profile concave]

Svensson, Harald, 1956, Method for exact characterizing of denudation surfaces, especially peneplains, as to position in space: Lund, Sweden, Lund Studies in Geography, Ser, A, no. 8, paging unknown. [trend-surface analysis to map \& distinguish erosional surfaces]

Swan, S.B.St.C., 1966, Stream representation on Malayan maps: Journal of Tropical Geography (Singapore), v. 22, no. 1, p. 1-9. [incomplete patterns pose problem for drainage-density calc.]

Sweeting, M.M., 1955, The land-forms of north-west County Clare: Transactions and Papers of the Institute of British Geographers, no. 21, p. 33-49. [elaborated the height-range diagram of Sparks 1949]

Sykioti, Olga, Deffontaines, Benoît, Chrowicz, Jean, Obert, Daniel, Marsily, Ghislain de, Lauverjat, Jacques, and Carvalho, Jose, 1996, Imagerie numérique de la surface topographie, Application à la géométrie d'un milieu karstique-Verneuil-sur-Avre (Perche) (in French w/ English summary \& figure captions): Bulletin de la Société Géologique de la France, v. 167, no. 2, p. 269-284.

[synth. incl. drainage net + slope, hillshade, \& envelope map fr 50-m DEM]

Szekely, Balazs, 2001, On the surface of the Eastern Alps; a DEM study: Tuebinger Geowissenschaftliche Arbeiten, Reihe A, Geologie, Palaeontologie, Stratigraphie, v. 60, 124 p. [neo orometry; elev. max, mean, range, std dev., autocorrelation, variogram, slope, ruggedness params, regions, etc.]

\section{$\mathbf{T}$}

Tada, Fumio, 1937, Relief energy of Jehol (2), in Geography of Jehol, Report of the first scientific expedition to Manchuria (in Japanese with German (\& English?) summary): Tokyo, p. 121-132, plate $4,1 / 2.5 \mathrm{M}$, and plate $5,1 / 1.5 \mathrm{M}$ (diff. method). [maps of 'relief energy'; resp. $8 \& 10$ relativerelief intervals, $14 \& 5 \mathrm{~km}$ spacing of elevs.]

Tahari, D., 1994, Les Modèles Numérique de Terrain—état de l'art: Bulletin trimestriel de la Société Belge de Photogrammétrie-Télédétection et Cartographie, no. 195-196, p. 25-40. [Frenchlanguage summary]

Taillefer, F., 1948, L'altitude moyenne des régions naturelles des Pyrénées françaises (in French): Revue de Géographie Alpine, v. 36, no. 1, p. 145-160. [mean elev. \& 'coeff. of articulation' for 52 \& 46 zones, resp.]

Tajchman, S.J., 1981, On computing topographic characteristics of a mountain catchment: Canadian Journal of Forest Research, v. 11, p. 768-774. [mean slope of TIN facets]

Takahashi, S., Ikeda, T., Shinagawa, Y., Kunii, T.L., and Ueda, M., 1995, Algorithms for extracting correct critical points and constructing topological graphs from discrete geographical elevation data, in Post, F., and Göbel, M., eds., Eurographics '95; Computer Graphics Forum, v. 14, no. 3: 
Blackwell Publishers, p. C181-C192. [current definitions of 'critical points' fail to meet the Euler Criteria in DEM representation of terrain features; raster image-processing, filtering]

Takken, Ingrid, Jetten, Victor, Govers, Gerard, Nachtergaele, Jeroen, and Steegen, An, 2001, The effect of tillage-induced roughness on runoff and erosion patterns: Geomorphology, v. 37, nos. 12, p. 1-14. [flowpaths from 5-m DEM in tilled fields improve runoff calcs.]

Takken, Ingrid, Govers, Gerard, Steegen, An, Nachtergaele, Jeroen, and Guérif, Jérome, 2001, The prediction of runoff flow directions on tilled fields: Journal of Hydrology, v. 248, nos. 1-4, p. 1-13. [logistic regr. eqn using slope, tillage direction, aspect, roughness]

Talling, P.J., Stewart, M.D., Stark, C.P., Gupta, Sanjeev, and Vincent, S.J., 1997, Regular spacing of drainage outlets from linear fault blocks: Basin Research, v. 9, no. 4, p. 275-302. [neo-orometry re/ Hovius 1996; stream spacing $(n=551)$ char. of indiv. blocks $(n=43)$, but mean ratios var. widely $=$ 1.4-4.1 the half-width of the block]

Tang, Tao, and Day, M.J., 2000, Field survey and analysis of hillslopes on tower karst in Guilin, southern China: Earth Surface Processes and Landforms, v. 25, no. 11, p. 1221-1235. [slopeprofile quantification]

Tanner, W.F., 1956, Parallel slope retreat in humid climate: Transactions, American Geophysical Union, v. 37 , no. 5, p. $605-607$. [3 stat. tests on $1 / 24 \mathrm{~K} \mathrm{~N}$. GA topo maps all suggest parallel retreat]

Tarboton, D.G., and Shankar, Ude, 1998, The identification and mapping of flow networks from digital elevation data (abs.): Eos, Transactions of the American Geophysical Union, v. 79, no. 45, supplement, p. F248. [3 methods; best = accumulated no. of locally concave grid cells]

Tate, N.J., 1995, The fractal dimension of topography: Norwich, UK, University of East Anglia, unpublished Ph.D. dissertation, 296 p. [details \& elab. for Tate 1998]

Tate, N.J., 1998a, Estimating the fractal dimension of synthetic topographic surfaces: Computers and Geosciences, v. 24 , no. 4, p. 325-334. [several methods: none 'optimal,' poor reproducibility; big biblio]

Tate, N.J., 1998b, Maximum entropy spectral analysis for the estimation of fractals in topography: Earth Surface Processes and Landforms-Technical and Software Bulletin, v. 23, p. 1197-1217. [MEM introduced; advantages \& disadv., tradeoffs $w /$ other methods]

Taud, Hind, Parrot, J.-F., and Alvarez, Roman, 1999, DEM generation by contour line dilation: Computers and Geosciences, v. 25, no. 7, p. 775-783. [contours dilate until they meet \& create intermediate contour lines]

Taylor, T.J., 1851, An Inquiry into the Operation of Running Streams and Tidal Waters, with a view to determine their principles of action, and an application of those principles to the improvement of the River Tyne: London, Longman Brown Green and Longmans, 119 p. [dynamic adjustment of form to process re. hydraulic geometry]

Tebbens, S.F., Burroughs, S.M., Barton, C.C., and Naar, D.F., 2001, Statistical self-similarity of hotspot seamount volumes modeled as self-similar criticality: Geophysical Research Letters, v. 28, no. 14, p. 2711-2714. [cum. freq-vol. distr. is truncated power law, scaling exp. $a=0.57(\sim D=$ 1.71)]

Temple, P.H., and Rapp, Anders, 1972, Landslides in the Mgeta area, western Uluguru Mountains, Tanzania: Geografiska Annaler, v. 54A, nos. 3-4, p. 157-193. [n=34; scar W, d, L; gradient; vol., dist. fr ridge crest; aspect] 
Thauer, Walter, 1955, Morphologische Studien im Frankenwald und Frankenwaldvorland:

Sonderabdruck aus den Mitteilungen der Fränkischen Geographischen Gesellschaft, no. 1, 232 p.; also 1954 dissertation. [relative-relief map by the circle method, published 1955 in Petermanns

Geogr. Mitt. as plate 1]

Thieken, A.H., Lücke, Andreas, Diekkrüger, Bernd, and Richter, Otto, 1999, Scaling input data by GIS for hydrological modelling: Hydrological Processes, v. 13, no. 4, p. 611-630. [diff. in DEM resolution (12.5-50m) makes huge diff. in channels \& params.; used KINEROS model]

Thom, B.G., 1970, Carolina Bays in Horry and Marion Counties, South Carolina: Geological Society of America Bulletin, v. 81, no. 3, p. 783-814. [A-L-W-ellipt. \& orient. stats.; nearest-neighbor tests; inconclusive]

Thomas, A.L., King, D., Dambrine, E., Couturier, A., and Roque, J., 1999, Predicting soil classes with parameters derived from relief and geologic materials in a sandstone region of the Vosges mountains (Northesastern France): Geoderma, v. 90, no. nos. 3-4, p. 291-305. [Stats for elev, slope, aspect, plan \& profile curv., dist. to stream fr 50-m DEM]

Thomas, R., Davis, C., Frederick, E., Manizade, S., Sonntag, J., Krabill, and McConnell, J., 1999, Greenland ice sheet elevation change since 1978 from radar and laser altimetry: Polar Geography, v. 23 , no. 3 , p. 169-184. [radar \& laser data agree; So. Greenland in balance]

Thomas, T.R., Rosén, B.-G., and Amini, N., 1999, Fractal characterisation of the anisotropy of rough surfaces: Wear, v. 232 , no. 1, p. 41-50. [3-D structure functions \& topothesy for diff. textures]

Thompson, J.A., Bell, J.C., and Butler, C.A., 2001, Digital elevation model resolution-effects on terrain attribute calculation and quantitative soil-landscape modeling: Geoderma, v. 100, nos. 1-2, p. $67-89$. [10m surveyed DEM $\pm 0.1 \mathrm{~m}$ precision vs. $30 \mathrm{~m} \mathrm{DEM} \pm 1.0 \mathrm{~m}$ prec.]

Thompson, M.M., 1956, How accurate is that map?: Surveying and Mapping, v. 16, no. 2, p. 164173. [admits U.S. vertical acc. standards lower than those in Europe \& that slope gradient needs to be taken into account]

Thompson, W.B., Thoenen, G.W., Moore, R.G., and Henderson, T.C., 1998, Extraction of microterrain features, in 1998 IMAGE Conference, Scottsdale, AZ, 2-7 August, The IMAGE Society, Inc., Proceedings: p. WBT 1-9, http://www.cs.utah.edu/vissim/bibliography/papers/ravinefeatures.pdf. [hydrol. analysis + computer vision, better than texture mapping; small ravines, military applic.]

Tillmann, E., 1915, Orometrie der Eifel (in German): Bonn, Univ. Bonn, Ph.D. diss., 92 p. [drainage density, mean slope \& height \&/or volume]

Tillo, A.A., 1890, Orography of European Russia based on a hypsometric map (in Russian): Proceedings of the Imperial Russian Geographical Society, v. 26, p. 8-32. [among earliest Russian morphometry]

Tillo, A.A., 1889, Untersuchung über die mittlere Höhe der Kontinente und die mittlere Tiefe der Meere in verschiedenen Breitenzonen (in German): Petermanns Geographische Mitteilungen, v. 35, no. 2, p. 48-49. [discusses Murray's 1888 paper \& 1887 Barthol. map; gives tables of elevs. \& depths by $10^{\circ}$ lat. bins]

Tobler, W.R., 1993, Non-isotropic modeling, in Three presentations on geographical analysis and modeling: Santa Barbara, CA, National Center for Geographic Information and Analysis, Technical Report 93-1, p. 1-4; http://www.geodyssey.com/papers/tobler93.html. [fr 'hiking fcn' \& DEM computes maps of min. time path to all points, isochrons, \& Gaussian curvatures] 
Tokunaga, Eiji, 1994, Selfsimilar natures of drainage basins, in Takaki, R., ed., Research of Pattern Formations: Tokyo, KTK Scientific Publishers, p. 445-468. [fractal D of channel network is same as that of its basin]

Tokunaga, Eiji, 2000, Dimensions of a channel network and space-filling properties of its basin: Transactions, Japanese Geomorphological Union, v. 21, no. 4, p. 431-449. [basin never filled by its streams; i.e. self-similar networks not space-filling in Tok. Branching Systems I \& II]

Tolentino, M., Gandolfi, N., and Paraguassu, A., 1968, Estudo morfometrico das bacias hidrograficas do Planalto de São Carlos (in Portuguese?): Rev. Brasil. Geogr., v. 30, no. 4, p. 42-50. [no info]

Toutin, Thierry, 1999, Error tracking of Radargrammetric DEM from RADARSAT images: IEEE Transactions on Geoscience and Remote Sensing, v. 37, no. 5, p. 2227-2238. [relief affects DEM accuracy; suggests guidelines]

Treitz, Paul, and Howarth, Philip, 2000, Integrating spectral, spatial, and terrain variables for forest ecosystems classification: Photogrammetric Engineering and Remote Sensing, v. 66, no. 3, p. 305317. [fair $(k=61 \%)$ result; need more detailed params. than elev, slope, \& relief]

Tsukamoto, Yoshinori, and Ohta, Takehiko, 1988, Runoff process on a steep forested slope: Journal of Hydrology, v. 102, no. 1-4, p. 165-178. [define 3 slope units by combining the 9 basic slope types]

Tucker, G.E., 1996, Modeling the large-scale interaction of climate, tectonics, and topography: State College, PA, Ph.D. thesis, Pennsylvania State University, Technical Report 96-003, >267 p. [applic. of SIBERIA DEM-based landscape model?]

Tucker, G.E., Catani, Filippo, Rinaldo, Andrea, and Bras, R.L., 2001, Statistical analysis of drainage density from digital terrain data: Geomorphology, v. 36, nos. 3-4, p. 187-202. [hillslope-flowpath length at nonchannel basin sites, fr. DEM, to get texture]

Tylor, Alfred, 1869, Section of surface of Lower Carboniferous series, Hirwain Common, Figure 7 in On Quaternary gravels: Quarterly Journal of the Geological Society of London, v. 25, first part, p. 73. [illustrates author's thesis (same volume, p. 7) of paper read Nov. 11, 1868 that longitudinal stream profiles are parabolic; see his abstract]

Tyurk, G.G., 1924, Statistika kol'tsevykh form lunniy poverkhnosti (statistics of ring-shaped landforms on the lunar surface; in Russian): Russk. Astron. Zhurn., v. 1, paging unknown; also 1927, Byull. Nabl. Ass. ob-va Lyubit. Astron., no. 9, paging unknown. [not seen; probably size-freq. stats]

\section{U}

Unbenannt, Maik, 1998, Ableitung und Bewertung morphometrischer Parameter ausgewählter Hangsegmente im Cottonwood Canyon, Colorado, USA mit Hilfe Digitaler Höhenmodelle (in German; Derivation \& eval. morph. param. selected slope segments ... DEM): Martin-LutherUniversity Halle-Wittenberg, Department of Geography, M.A. thesis (unpublished), paging unknown. [multivariate analysis of slope, aspect, profile \& plan convexity]

Unbenannt, Mail, 1999, Generation and analysis of high-resolution digital elevation models for morphometric relief classification, represented at a cuesta scarp sope on the Colorado Plateau, USA., in Gläßer, C., Will, H., and Engler, Th., eds., Environmental Assessment and Monitoring, 3rd German-Dutch Symposium KvAG (Niederlande) / DGPF-AK "Interpretation von

Fernerkundungsdaten", 28-29 April, Halle, Germany, Proceedings: CD-Rom; http://mlucom6.urz.unihalle.de/geographie/phys/UNBENANN/genera.htm. [see Unbennent 1998]

Unwin, D.J., 1981, Introductory Spatial Statistics: London and New York, Methuen, 212 p. [Fleming \& Hoffer slope method fr DEM; also Ritter (1987)] 
U.S. Geological Survey, 2001, HYDRO1k Elevation derivative database: Sioux Falls, ND, EROS Data Center; http://edcdaac.usgs.gov/gtopo30/hydro/index.html. [gridded river network at $1 \mathrm{~km}$ resolution; global coverage planned]

Utsunomiya, Hidehiko, Nagao, Fumiaki, and Hiraoka, Tateki, 1987, Effects of topographic factors on local wind properties: Natural Disaster Science, v. 9, no. 2, p. 77-95. [wind-tunnel modeling of road-cut form; ridge \& open-cut height \& slope, wind dir.]

\section{V}

Vacher, H.L., 1999, Computational geology 5-if geology, then calculus: Journal of Geoscience education, v. 47, no. 2, p. 166-175. [tutorial; landform examples: Hack's equation; also allometry]

Vacher, H.L., 1999, Computational geology 8-the power function: Journal of Geoscience education, v. 47 , no. 5 , p. $473481-175$. [fun tutorial; landform examples: slope, area \& volume, \& denudation]

Vaessen, E.M.J., 1997, A qualitative comparison of DEM data capturing techniques (in Dutch): Geodesia, v. 39, no. 11, p. 483-490. [no info]

Vakhtin, B., 1931, Experiments to determine mathematical characteristics of relief for the CCR (in Russian): Geodezist, no. 11-12, p. 43-55. [no info]

Valentine, P.C., Baker, J.L., Unger, T.S., and Polloni, Christopher, 1998, Sea floor topographic map and perspective-view imagery of Quadrangles 1-18, Stellwagen Bank National Marine Sanctuary off Boston, Massachusetts: U.S. Geological Survey, Open-file report 98-138, one CD-ROM; http://woodshole.er.usgs.gov/project-pages/stellwagen/arc/sbtopo/readme.html. [block of 18 topo. maps fr. multibeam echo-sounder data; $5 \mathrm{~m}$ contour interval]

Valentine, P.C., Baker, J.L., and Unger, T.S., 2001, Sun-illuminated sea floor topography of Quadrangle 13 in the Stellwagen Bank National Marine Sanctuary off Boston, Massachusetts: U.S. Geological Survey, Geologic Investigations Map 1-2713, 1/25,000 scale. [one of a block of 18 shaded-relief maps of glacial features fr. multibeam echo-sounder data; same authors; illum. $45^{\circ}$ elev. at $350^{\circ}, 4 \mathrm{X}$ VE, $5 \mathrm{~m}$ C.I.; glacial features \&textures]

Valeo, C., and Moin, S.M.A., 2000, Variable source area modelling in urbanizing watersheds: Journal of Hydrology. v. 228, nos. 1-2, p. 68-81. [TOPMODEL (helpful summary) adapted to urban basins]

Vales, D.J., 1996, User's manual for ELKVULN, an elk vulnerability, hunter, and population projection program, version 1.00: Moscow, ID, Department of Fish and Wildlife Resources, University of Idaho, 24 p. [PC software pkg uses mean slope \& 'aspect contagion' ('broken' vs continuous)]

van Burkalow, Anastasia, 1945, Angle of repose and angle of sliding friction: Bulletin of the Geological Society of America, v. 56, no. 6, p. 669-707. [early attempt to numerically model talus slopes]

van der Beek, P.A., and Braun, Jean, 1998, Numerical modelling of landscape evolution on geological time-scales-a parameter analysis and comparison with the south-eastern highlands of Australia: Basin Research, v. 10, no. 1, p. 49-68. [comprehensive DEM neo-orometry (incl. correl.); roughness amplitude, R, hyps. integral, elev., fractal $\boldsymbol{D}$; variograms, etc.]

van Deursen, W.P.A., and Wesseling, C.G., 1995, The PCRaster package: University of Utrecht, The Netherlands, Technical Report of the Department of Physical Geography, 198 p.

<http://www.geog.uu.nl/pcraster.html>. [includes DEM-to-watershed transformation] 
van Dijk, W., and Le Heux, J.W.N., 1952, Theory of parallel rectilinear slope recession, I and II: Koninklijke Nederlandsche Akademie van Wettenschappen, Proceedings, v. 55 B, p. 115-122 and 123-129. [relation among non-parallel slope retreat, talus accumulation, \& slope shape]

van Kreveld, Marc, 1996, Variations on sweep algorithms-efficient computation of extended viewsheds and class intervals, in Kraak, M.-J., Molenaar, Martien and Fendel, E.M., eds., International Symposium on Spatial Data Handling, 7th, Delft, Neth., Proceedings: Edinburgh, Taylor \& Francis, v. 2, p. 843-855. [2 new applics. of plane sweep paradigm]

van Remortel, R.D., Hamilton, M.E., and Hickey, R.J., 2001, Estimating the LS factor for RUSLE through iterative slope length processing of DEM elevation data: Cartography (Canberra), v. 30, no. 1, p. 27-35. [updates 1994 Hickey et al. calcs. for RUSLE]

van Westen, C.J., Rengers, N., Terlien, M.T.J., and Soeters, R., 1998, Prediction of the occurrence of slope instability phenomena through GIS-based hazard zonation: Geologische Runschau, v. 86, no. 2, p. 404-414. [excellent state-of-art review; 3 scale levels]

Vaughan, D.G., Bamber, J.L., Giovinetto, Mario, Russell, Jonathan, and Cooper, A.P.R., 1999, Reassessment of net surface mass balance in Antarctica: Journal of Climate, v. 12, no. 4, p. 933946. [24 ice-flow drainage basins fr 10-km DEM (ERS-1) by DEM-to-watershed software]

Veinberg, B.P., 1934, Experiment to mathematically determine geomorphological concepts and mathematical characteristics of geomorphological properties, in All-Union Geographical Congress, 1st, 11-18 April 1933, State Geographical Society, Leningrad, Proceedings: v. 3, p. 126-135. [no info]

Veitzer, S.A., and Gupta, V.K., 2000, Random self-similar river networks and derivations of generalized Horton laws in terms of statistical simple scaling: Water Resources Research, v. 36, no. 4 , p. 1033-1048. [new class of models, recursive process, unlike trad. random model]

Velde, B., 1999, Structure of surface cracks in soil and muds: Geoderma, v. 93, nos. 1-2, p. 101-124. [segment \& intersection freq. of crack networks; also width]

Veneziano, Daniele, and lacobellis, Vito, 1999, Self-similarity and multifractality of topographic surfaces at basin and subbasin scales: Journal of Geophysical Research, v. 104, no. B6, p. 12,797-12,812. [in this 1st (?) comparison of $Z$ with XY methods \& results, concludes Z-based computations of fractal $\boldsymbol{D}$ are deficient \& misleading, \& that fluvial terrain is fundamentally selfsimilar, not multi-fractal]

Veneziano, Daniele, Moglen, G.E., Furcolo, Pierluigi, and lacobellis, Vito, 2000, Stochastic model of the width function: Water Resources Research, v. 36, no. 4, p. 1143-1157. [new models based on iterated random pulse (IRP) processes]

Veneziano, Daniele, and Niemann, J.D., 2000a, Self-similarity and multifractality of fluvial erosion topography 1. mathematical conditions and physical origin: Water Resources Research, v. 36, no. 7, p. 1923-1936. [expressed by topo increments in subbasins; dynamic modeling]

Veneziano, Daniele, and Niemann, J.D., 2000b, Self-similarity and multifractality of fluvial erosion topography 2. scaling properties: Water Resources Research, v. 36, no. 7, p. 1937-1951. [realworld topo variations violate conditions of s-s \& multifrctly]

Ventura, S.J., and Irvin, B.J., 2000, Automated landform classification methods for soil-landscape studies, in Wilson, J.P., and Gallant, J.C., eds., Terrain Analysis-Principles and Applications, New York, John Wiley and Sons, p. 267-294. [reviews slope-form taxonomy; ARC/INFO, fuzzy, other clustering on TAPES variables] 
Verdin, K.L., 1997, A system for topologically coding drainage basins and stream networks, in 1997 ESRI International User Conference, San Diego, CA, July 8-11, Proceedings: Redlands, CA, Environmental Systems Research Institute, Inc., CD-ROM; http://www.esri.com/library/userconf/proc97/proc97/to350/pap311/p311.htm. [hydro. modeling using GTOPO30 DEM]

Verdin, K.L., and Greenlee, S.K., 1998, HYDRO1k documentation: Sioux Falls, ND, U.S. Geological Survey, EROS Data Center; http://edcdaac.usgs.gov/gtopo30/hydro/readme.html. [8-parameter GIS database, incl 1-km DEM corrected by the Hutchinson algorithm]

Verdin, K.L., and Verdin, J.P., 1999, A topological system for delineation and codification of the Earth's river basins: Journal of Hydrology, v. 218, nos. 1-2, p. 1-12. [Otto Pfafstetter's concept; based on topo \& thus impl. by DEMs, here NA GTOPO30]

Veregin, Howard, 2000, Quantifying positional error induced by line simplification: International Journal of Geographical Information Science, v. 14, no. 2, p. 113-130. [can find freq. bandwidth that eliminates most vertices for streams, etc.]

Vernon, Peter, 1966, Drumlins and Pleistocene ice flow over the Ards/Strangford Lough area, County Down, Ireland: Journal of Glaciology, v. 6, p. 401-409. [perpendicular \& parallel spacing, meas. fr. drumlins center-to-center]

Vertessy, R.A., Hatton, T.J., O'Shaughnessy, P.J., and Jayasuriya, M.D.A., 1993, Predicting water yield from a mountain ash forest catchment using a terrain analysis based catchment model: Journal of Hydrology, v. 150, nos. 2-4, p. 665-700. [describes implementation of TOPOG software pkg. to get network of quadrilateral terrain elements]

Veverka, Joseph, and 32 others, 2000, NEAR at Eros-imaging and spectral results: Science, v. 289, no. 5487, p. 2088-2097. [Near Earth Asteroid Rendezvous; d/D for 9 sub-pristine impact craters $(0.65 \mathrm{~km} \leq \mathrm{D} \leq 5.5 \mathrm{~km})=0.12-0.16]$

Veverka, Joseph, and 32 others, 2001, Imaging of small-scale features on 433 Eros from NEAR-evidence for a complex regolith: Science, v. 292, no. 5516, p. 484-488. [Near Earth Asteroid Rendezvous; $d / D$ for craters $>20 m-100 m \approx 0.2]$

Vielra, G.T., 2000, Glacial and periglacial data integration in a GIS-methodology used in the Sierra da Estrela, Portugal: Geological Quarterly (Warsaw), v. 44, no. 1, p. 27-31. [var. image maps derived fr. 10-m DEM]

Vieux, B.E., 1993, DEM aggregation and smoothing effects on surface runoff modeling: Journal of Computing in Civil Engineering, v. 7, no. 3, p. 310-338. [low-pass filtering a 7.5' DEM by convolution to reduce spurious pits]

Vigil, J.F., Pike, R.J., and Howell, D.G., 2000, A tapestry of time and terrain: U.S. Geological Survey, Miscellaneous Investigations map, I-2720 (pamphlet accompanies map), scale 1/3,500,000; $<$ http://tapestry.usgs.gov/>. [overlay of color geologic map onto shaded relief for lower 48 states]

Vincent, Luc, and Soille, Pierre, 1991, Watersheds in digital spaces-An efficient algorithm based on immersion simulations: IEEE Transactions on Pattern Analysis and Machine Intelligence, v. 13, no. 6, p. 583-598. [using the grey scale-to-'watershed' transformation for image analysis]

Vinogradov, B.V., 1999, Remote sensing-based monitoring of geosystems using morphometric methods: Mapping Sciences and Remote Sensing, v. 36, no. 3, p. 223-232. [indices of shape, nonuniformity, relative location, proximity, connectivity, \& fractal D of strips \& patches] 
Vitek, J.D., and Tarquin, Pamela, 1984, Characteristics of relict stone polygons, Sangre de Cristo Mountains, Colorado, USA: Zeitschrift für Geomorphologie, v. 28, no. 4, p. 455-465. [n=193 mapped @ 1/240; meas. I, w, A, slope, relief, \& spacing; veg. growth obscures conclus.]

Vivas Miranda, A., and Paz Gonzalez, A., 1998, Influencia de las características iniciales de la superficie y la precipitacíon en la dimensíon fractal del microrrelieve del suelo (Influence of initial surface characteristics and rainfall on the fractal dimension of soil microrelief, in Spanish): Cadernos do Laboratorio Xeolóxico de Laxe (Univ. Coruña), v. 23, p. 121-136. [laser profilometer; RMS method for D (Hurst exponent)]

Vogt, P.R., 2000, Endoresment of global ocean mapping project: Eos, Transactions of the American Geophysical Union, v. 81, no. 43, p. 498 . [more on GOMap DEM, a costly but excellent idea]

Vogt, Peter, and Jung, W.-Y., 2000, GOMap-a matchless resolution to start the new millenium: Eos, Transactions of the American Geophysical Union, v. 81, no. 23, p. 254, 258. [proposes 100-m res. mapping of entire ocean floor to get bathym. DEM]

Voigt, Erika, 1940, Neue hypsographische Kurven im Atlantischen Ozean (in German): Mitteilungen der Gesellschaft für Erdkunde zu Leipsig, v. 55, p. 5-30 \& 5 fold-outs. [hypso diagrams fr maps fr recent ship surveys; mid-Atlantic ridge]

Voislavsky, L.K., 1986, Differential digital terrain model (in Russian): Geodesiya, Aerophotosyemka i Cartographiya, no. 44, p. 10-19. [no info]

Voislavsky, L.K., 1989, Differential digital terrain model with an irregular distribution of points (in Russian): Geodesiya, Aerophotosyemka i Cartographiya, no. 50, p. 12-19. [no info]

Voronov, P.S., 1968, Essays on regularities in morphometry of the global topography of the Earth (in Russian): Nauka, Leningrad, 123 p. [no info]

Voronoi, M.G., 1908, Nouvelles applications des parametres continus a la theorie des formes quadratiques (in French): J. Reine u. Angew. Math., v. 134, p. 198-287. [surface tessellation; polygon defined by lines bisecting lines connecting neighboring points]

Vörösmarty, C.J., Fekete, B.M., Meybeck, M., and Lammers, R.B., 2000a, Geomorphometric attributes of the global system of rivers at 30-minute spatial resolution: Journal of Hydrology, v. 237, nos. 1-2, p. 17-39. [7 chars. for 50 largest of 6200 basins, fr ETOPO5-to-watershed topology]

Vörösmarty, C.J., Fekete, B.M., Meybeck, M., and Lammers, R.B., 2000b, Global system of rivers-its role in organizing continental land mass and defining land-to-ocean linkages: Global Biogeochemical Cycles, v. 14, no. 2, p. 599-621. [automated procedure with manual correction to reduce error]

\section{W}

Wadhawan, S.K., 1998, Late Quaternary evolution of clustered parabolic megadunes in Thar desert, India, in Alsharhan, A.S., Glennie, K.W., Whittle, G.L., and Kendall, C.G.St.C., eds., Quaternary Deserts and Climatic Change: Balkema, Rotterdam, p. 185-195. [several morphometric measures; height/spacing relation]

Waldrip, D.B., and Roberts, M.C., 1972, The distribution of slopes in Indiana: Proceedings of the Indiana Academy of Sciences, v. 81, p. 251-257. [automated gradient measurement from topo maps]

Wagner, Hermann, 1903a, Das Messen auf Karten (measurements on maps), § 112-115 in Lehrbuch der Geographie, v. 1 Einleitung Allgemeine Erdkunde (in German; ... intro to gen'l Earth science): 
Hannover \& Leipzig, Hahn, p. 230-240. [review of cartometry complementing that of orometry in same textbook]

Wagner, Hermann, 1903b, Orometrische Werte (the value of orometry), $\S 173$ in Lehrbuch der Geographie, v. 1 Einleitung Allgemeine Erdkunde (in German; ... intro to gen'l Earth science): Hannover \& Leipzig, Hahn, p. 398-396. [review of orometry (this std. textbook went through many editions $\sim 1880-1938)]$

Wagner, Paul, 1933, Morphometrische Studien aus Sachsen; Fehlerquellen und Fehlergrenzen (in German; ... Saxony, sources \& margins of error): Geographisches Anzeiger, v. 34, p. 38-44. [no info]

Walker, J.P., and Willgoose, G.R., 1999, On the effect of digital elevation model accuracy on hydrology and geomorphology: Water Resources Research, v. 35, no. 7, p. 2259-2268. ['groundtruth' compared to topo-map and photogram. DEMs: use publ. DEMs w/ caution]

Walschot, L., 1973, De hellingkaart (in Dutch): Natuurwetenschappelijk Tijdschrift, v. 55, p. 210-226. [manual method of slope mapping, not obsoleted by computer where detail needed]

Walton, T.L. Jr., 1999, Shoreline rhythmic pattern analysis: Jouirnal of Coastal Research, v. 15, no. 2, p. 379-387. [low-freq. $(12 \mathrm{~km})$ non-stationary oscillations fr. time-series analysis]

Waltz, J.P., 1971, An analysis of selected landslides in Alameda and Contra Costa Counties, California: Bulletin of the Association of Engineering Geologists, v. 8, no. 2, p. 153-163. [l.s.specific measures of plan \& profile curvature the only signif. params.]

Wang, Jianjun, Robinson, G.J., and White, Kevin, 2000, Generating viewsheds without using sightlines: Photogrammetric Engineering and Remote Sensing, v. 66, no. 1, p. 87-90. [DEMbased 'reference planes' much faster than sightlines]

Wang, Kai, Lo, C.-P., Brook, G.A., and Arabnia, H.R., 2001, Comparison of existing triangulation methods for regularly and irregularly spaced height fields: International Journal of Geographical Information Science, v. 15, no. 8, p. 743-762. [Delaunay still the best of 8 schemes in natural terrain]

Wang, Xinhao, and Yin, Zhi-Yong, 1997, An evaluation of using Arclnfo to extract basin physiographic parameters from DEMs, in 1997 ESRI International User Conference, San Diego, CA, July 8-11, Proceedings: Redlands, CA, Environmental Systems Research Institute, Inc., CDROM; http://www.esri.com/library/userconf/proc97/proc97/to250/pap215/p215.htm. [20 basins in W. VA compared; 1:24K, 1:250K, 1:100K USGS data]

Ware, J.M., and Kidner, D.B., 1997, A flexible storage-efficient TIN data model, in Hodgson, S., Rumor, and Harts, J.J., eds., Joint European Conference on Geographical Information, 3rd, Vienna, Austria, Proceedings: Amsterdam, IOS Press, v. 1, p. 48-57. [triangulates on-the-fly at run time; stores no topology, other advantages]

Ware, J.M., Kidner, D.B., and Herbert, M.J., 1996, Terrain in perspective-DEMs or TINs, in JECGl'96, Joint European Conference on Geographical Information, 2nd, 27-29 March, Barcelona, Proceedings: Amsterdam, IOS Press, p. 388-397. [no info]

Warner, R.C., and Budd, W.F., 2000, Derivation of ice thickness and bedrock topography in data-gap regions over Antarctica: Annals of Glaciology, v. 31, p. 191-197. [use DEM \& ice distrib. via balance fluxes \& assumptions on ice-flow dynamics]

Warntz, William, 1967, Concepts and applications-spatial order, Part I and Part II section G, in Warntz, William, and Woldenberg, M.J., Geography and the properties of surfaces series, paper no. 1: Harvard Papers in Theoretical Geography, Cambridge, MA, Harvard University, Graduate School 
of Design, Laboratory for Computer Graphics and Spatial Analysis, for Geography Branch, Office of Naval Research, Project NR 389-147, Technical Report, p. 11-94, 173-184. [11 sections review network, surface topology; 'rediscovery' of concept origins; cites Reech (1858, including a free transl.), Cayley, \& Clerk Maxwell]

Warntz, William, and Waters, Nigel, 1975, Network representations of critical elements of pressure surfaces: Geographical Review, v. 65 , no. 4, p. 476-492. [applies peak-pit-pass-pale / ridgecourse-slope line topology; good discussion of critical lines]

Watson, D.F., 1992, Contouring-a guide to the analysis and display of spatial data: Oxford, UK, Pergamon, 340 p. [comprehensive survey of the various contouring methods]

Watters, T.R., Schultz, R.A., Robinson, M.S., and Cook, A.C., 2002, The mechanical and thermal structure of Mercury's early lithosphere: Geophysical Research Letters, v. 29, no, 11, p. 37-1 to 374. [Topo. profile of 1.3-km-high lobate scarp fr DEM fr Mariner 10 stereo pairs]

Weaver, J.D., 1960, Note on higher level erosion surfaces of Puerto Rico: Caribbean Geol. Conf., 2d, Mayagueez, P.R., Jan. 4-9, 1959, Trans., p. 96-98. [altimetric curves fr 38 1/30,000 quads; 5 levels, 2 known]

Webber, B.B., 1995, Testing the vertical accuracy of United States Geological Survey 7.5 minute and 1 degree digital elevation models: Moscow, ID, University of Idaho, unpublished MS. thesis, 73 p. [stat. comp. yields true accuracy \& potential problems in diff. terrains]

Weber, Dominique, and Herrmann, Agnes, 2000, Contribution de la photogrammétrie numérique à l'étude spatio-temporelle de versants instables-l'exemple du glissement de terrain de SuperSauze (Alpes-de-Haute-Provence, France) (in French with English summary \& figure captions): Bulletin de la Société Géologique de la France, v. 171, no. 6, p. 637-648. [6 DEMs, difference maps, trace morph. evolution of a complex flow slide]

Wechsler, S.P., 1999, Digital elevation model (DEM) uncertainty-evaluation and effect on topographic parameters: Redlands, CA, ESRI User Conference, http://www.esri.com/library/userconf/proc99/proceed/papers/pap262/p262.htm\#_Author_Informatio n; or http://www.csulb.edu/ wechsler/Dissertation/P262/P262.html. [used DEM metadata \& spatial char.; Monte-Carlo simulations]

Wechsler, S.P., 2000, Effect of DEM Uncertainty on Topographic Parameters, DEM Scale and Terrain Evaluation: SUNY Syracuse, Ph.D. dissertation, 380 p.; http://www.csulb.edu/ wechsler/Dissertation/Abstract_web.doc. [ArcView-implemented Monte Carlo simulations use random error fields to quantify uncertainty in DEM, slope, upslope contrib. A, \& topo. index $(\mathrm{TI})]$

Weibel, Robert, 1990, Verarbeitung und Anwendung digitaler Geländemodelle im Bereich der Geographie (in German; Processing \& applying DTMs in Geography): Geographica Helvetica, v. 45, no. 4 , p. $145-153$. [no info]

Weibel, Robert, 1997, Digital terrain modelling for environmental applications-a review of techniques and future trends, in Hodgson, S., Rumor, and Harts, J.J., eds., Joint European Conference on Geographical Information, 3rd, Vienna, Austria, Proceedings: Amsterdam, IOS Press, v. 1, p. 464474. [a subsystem of GIS; DEM def., tasks, functions (DEM gen., manip., visual., applic.), trends]

Weih, R.C., and Smith, J.L., 1996, The influence of cell slope computation algorithms on a common forest management, in Kraak, M.-J., Molenaar, Martien and Fendel, E.M., eds., International Symposium on Spatial Data Handling, 7th, Delft, Neth., Proceedings: Edinburgh, Taylor \& Francis, v. 2, p. 857-875. [compares 8 slope methods, $6 \sim$ similar, 2 not; large area diffs. result] 
Welch, D.M., 1967, Slope evolution on recessional moraines: University of Alberta, unpublished M.SC. thesis, $100 \mathrm{p}$. [field profiles on 23 dated moraines (86 yrs.) reveal slope converges to 2530 deg.]

Welch, D.M., 1970, Substitution of space for time in a study of slope development: Journal of Geology, v. 78 , no. 2, p. 234-239. [field profiles on recessional moraines; slope dispers. < rapidly w/ time.]

Wells, N.A., 1999, ASTRA.BAS-a program in QuickBasic 4.5 for exploring rose diagrams, circular histograms and some alternatives: Computers and Geosciences, v. 25, no. 6, p. 641-654. [great flexibility, plus less-biased 'corona dot' and 'mean-deviation dot' diagrams]

Werner, B.T., 1995, Eolian dunes-computer simulations and attractor interpretation: Geology, v. 23, no. 12, p. 1107-1110. [simple transport model yields remarkably 'real' barchans, linear \& star dunes]

Werner, B.T., 1999, Complexity in natural landform patterns: Science, v. 284, no. 5411, p. 102-104. [theories: self-org. in temp. hierarchy > reductionism \& universality]

Werner, B.T., and Hallet, B., 1993, Numerical simulation of self-organized stone stripes: Nature, v. 361 , no. 6408 , p. $142-144$. [std. dev. $/$ mean $=1 / 4$ for real $\& 2 \mathrm{D}$ simulated forms; means close]

Werner, B.T., and Kocurek, G., 1997, Bed-form dynamics-does the tail wag the dog?: Geology, v. 25 , no. 9, p. 771-774. [orientation of bed-form crests related to 'defects' (I. \& r. terminations) in pattern]

Werner, Christian, 1972, Two models for Horton's law of stream numbers: The Canadian Geographer, v. 9, p. 50-68. [relation of str. no. to order of infinite topol. random networks obeys Horton's law for bifurcation ratio 4 ; proved by combinatorial theory]

Werner, Christian, 1982, Analysis of length distribution of drainage basin perimeter: Water Resources Research, v. 18, no. 4, p. 997-1005. [can't be derived from the random model; descr, model of ridge \& channel nets]

Western, A.W., Grayson, R.B., Blöschl, Günter, willgoose, G.R., and McMahon, T.A., 1999, Observed spatial organization of soil moisture and its relation to terrain indices: Water Resources Research, $v$. 35 , no. 3, p. 797-810. [organiz. high in wet season, low in dry; need diff. indices for ea.]

Weverinck, Th., 1936, Beiträge zur Tektonik und Morphologie von Schonen: Adhandl. Geol.-paläont. Inst. Univ. Griefswald, v. 42, 1/200K map. [relative relief map on 2-km squares; 6 relief intervals]

Wheatly, David, 1995, Cumulative viewshed analysis-a GIS-based method for investigating intervisibility, and its archaeological application, in Lock, G., and Stancic, Z., eds., Archaeology and GIS-a European Perspective: London, Taylor and Francis, p. 171-186. [summed viewsheds for several sites = 'cumulative viewshed analysis']

Wheeler, D.A., 1979, Studies of river longitudinal profiles from contoured maps: Area (London), v. 11, no. 4, p. 321-326. [profile concavity?]

Wheeler, D.A., 1979, The overall shape of longitudinal profiles of streams, in Pitty, A.F., ed., Geographical Approaches to Fluvial Processes: Norwich UK, Geobooks, p. 241-260. [profile concavity increases with total fall for 115 UK rivers]

Whipple, K.X., 2001, Fluvial landscape response time-how plausible is steady-state denudation?, in Pazzaglia, F.J., and Knuepfer, P.L.K., eds., The steady-state orogen-concepts, field observations, and models: American Journal of Science, v. 302, nos. 4 \& 5, p. 313-512. [model params. fit to measured channels test model in Central Range of Taiwan] 
Whipple, K.X., and Tucker, G.E., 1999, Dynamics of the stream-power river incision model-implications for height limits of mountain ranges, landscape response timescales, and reseach needs: Journal of Geophysical Research, v. 104, no. B8, p. 17,661-17,674. [state-of-art review of work on longitudinal stream profiles]

Whipple, K.X., Kirby, Eric, and Brockelhurst, S.H., 1999, Geomorphic limits to climate-induced increases in topographic relief: Nature, v. 401, no. 6748, p. 39-43. [scales of relief; fluvial \& glacial relief production; E.E. Small's comments pp. 31-33]

Whitman, Dean, Gubbels, Timothy, and Powell, Linda, 1999, Spatial interrelationships between lake elevations, water tables, and sinkhole occurrence in central Florida-a GIS approach: Photogrammetric engineering and Remote Sensing, v. 65 , no. 10, p. 1169-1178. [distance to nearest sink, etc.; sinks not spatially random]

Wichman, R.W., 1999, Internal crater modification on Venus-recognizing crater-centered volcanism by changes in floor morphometry and floor brightness: Journal of Geophysical Research, v. 104, no. E9, p. 21,957-21,977. [bright- \& dark-floored craters diff.; floor/rim diam., elev., etc.]

Wichman, R.W., and Schultz, P.H., 1995, Floor-fractured impact craters on Venus-implications for igneous crater modification and local magmatism: Journal of Geophysical Research, v. 100, no. E2, p. 3233-3244. [arith. floor \& peak-ring D for 4 crater types as f(arith. rim D)]

Wieczorek, G.F., Harp, E.L., Mark, R.K., and Bhattacharyya, A.K., 1988, Debris flows and other landslides in San Mateo, Santa Cruz, Contra Costa, Alameda, Napa, Solano, Sonoma, Lake, and Yolo Counties, and factors influencing debris-flow distribution, in Ellen, S.D., and Wieczorek, G.F., eds., Landslides, floods, and marine effects of the storm of January 3-5, 1982, in the San Francisco Bay Region, California: U.S. Geological Survey Professional Paper 1434, p. 133-161. [30-m DEM slopes for debris-flow sources contrasted with all slopes]

Wieczorowski, M., 2001, Spiral sampling as a fast way of data acquisition in surface topography: International Journal of Machine Tools and Manufacture, v. 41, Nos. 13-14, p. 2017-2022. [spiral of Archimedes is more efficient than grid sampling]

Wigmosta, M.S., and Lettenmaier, D.P., 1999, A comparison of simplified methods for routing topographically driven subsurface flow: Water Resources Research, v. 35, no. 1, p. 255-264. [DHSVM vs. TOPMODEL: good agreement, but large differences remain]

Wijdenes, D.J., Poesen, Jean, Vandererckhove, Liesbeth, Nachtergaele, Jeroen, and De Baerdemaeker, Jo, 1999, Gully-head morphology and implications for gully development on abandoned fields in a semi-arid environment, Sierra de Gata, southeast Spain: Earth Surface Processes and Landforms, v. 24, no. 7, p. 585-603. [correl. of 9 params on 59 catchments suggest geomorph. conclusions]

Wilbur, S.C., 1988, Surging vs nonsurging glaciers-a comparison using morphometry and balance: Fairbanks, AK, University of Alaska, unpublished M.Sc. thesis, paging unknown. [univariate analysis only]

Willemin, J.H., 2000, Hack's Law-sinuosity, convexity, elongation: Water Resources Research, v. 36, no. 11, p. 3365-3374. [38 hand-digitized perims. \& channels, better than DEM data; exponent 0.50-0.60; elongation with > size not general]

Willett, S.D., Slingerland, Rudy, and Hovius, Niels, 2001, Uplift, shortening, and steady-state topography in active mountain belts, in Pazzaglia, F.J., and Knuepfer, P.L.K., eds., The steadystate orogen-concepts, field observations, and models: American Journal of Science, v. 302, nos. $4 \& 5$, p. 455-485. [tectonic/surface-process model compared $w /$ topo profiles of mountains in WA USA, Taiwan, N.Z.] 
Willgoose, G.R., Bras, R.L., and Rodríguez-Iturbe, Ignacio, 1991, A physically based coupled network growth and hillslope evolution model, 1, Theory, 2, Applications: Water Resources Research, v. 27 , no. 7, p. 1671-1684 \& 1685-1696. [SIBERIA; model for studying geomorphic evolution of landforms subject to erosion \& mass transport]

William-Olsson, William, 1975, Relative relief map of the western half of Europe, Figure 1 in A prelude to regional geography-two maps of Europe: Stockholm, Esselte Map Service, 19-p. pamphlet, p. 2. [data of Rutkis, 1971 (100 km² circles); $1 / 18 \mathrm{M}, 8$ geometric intervals; originial was in color at $1 / 4 \mathrm{M}]$

Williams, G.J., 1967, A relative relief map of Sierra Leone: Sierra Leone Geographical Journal, v. 11, no. 1, p. 11-14. [no info]

Williams, G.P., and Guy, H.P., 1971, Debris avalanches-a geomorphic hazard, in Coates, D.R., ed., Environmental Geomorphology, proceedings of the first annual geomorphology symposium: Binghamton, N.Y., SUNY, Publications in Geomorphology, p. 25-46. [slope/distance plots, azimuth, slope length]

Williams, R.M.E., and Phillips, R.J., 2001, Morphometric measurements of martian valley networks from the Mars Orbiter Laser Altimeter (MOLA) data: Journal of Geophysical Research, v. 106, no. E10, p. 23,737-23,751. [valley depth $(\sim 109 \mathrm{~m} \pm)$, width $(2 \mathrm{~km} \pm) \&$ ratios; V- and U-shaped valleys modeled]

Wilson, B.N., Leaf, R.B., and Hansen, B.J., 2001, Microrelief meter for field topography measurements: Transactions, American Society of Agricultural Engineers, v. 44, no. 2, p. 289-295. [portable, automated, non-contact; X, Y, Z accuracy $\sim \pm 0.25 \mathrm{~mm}, \pm 1.5 \mathrm{~mm}, \pm 0.5 \mathrm{~mm}$, resp.]

Wilson, J.D., Klotz, L.D., and Nagaraj, C., 1997, Automated measurement of aggregate indices of shape: Particulate Science and Technology, v. 15, no. 1, p. 13-35; also 1995, Federal Highway Administration Report FHWA-RD-95-116, paging unknown. [quant. graphs of roundness \& angularity fr video-image analysis]

Wilson, J.P., and Gallant, J.C., eds., 2000a, Terrain analysis-Principles and Applications: Chichester UK \& NY, Wiley, 479 p. [proc. of 25-29 Nov. 1996 ACLEP workshop, Creation and Applications of Digital Elevation Models (DEMs) in Land Resource Assessment; applic. of TAPES (Terrain Analysis Programs for the Environmental Sciences) algorithms, post-lan Moore, esp. chapters 1-5, p. 1-161]

Wilson, J.P., and Gallant, J.C., 2000b, Digital terrain analysis, in Wilson, J.P., and Gallant, J.C., eds., Terrain Analysis-Principles and Applications: New York, Wiley, p. 1-27. [mostly intro \& review, plus summary of book chapters, emph. on DEMS \& TAPES algorithms]

Wilson, J.P., and Gallant, J.C., 2000c, Secondary topographic attributes, in Wilson, J.P., and Gallant, J.C., eds., Terrain Analysis-Principles and Applications: New York, Wiley, p. 87-131. [topo wetness, stream power, radiation \& temp. indices fr DEMs \& TAPES software]

Wilson, J.P., Repetto, P.L., and Snyder, R.D., 2000, Effect of data source, grid resolution, and flow routing method on computed topographic attributes, in Wilson, J.P., and Gallant, J.C., eds., Terrain Analysis-Principles and Applications: New York, Wiley, p. 133-161. [used USGS 7.5' DEMs of Montana \& Idaho]

Wimmer, Christian, Siegmund, Robert, Schwäbisch, Marcus, and Moreira, João, 2000, Generation of high precision DEMs of the Wadden Sea with airborne interferometric SAR: IEEE Transactions on Geoscience and Remote Sensing, v. 38, no. 5, p. 2234-1145. [2.5-m spacing \& 5-cm rms elev. accuracy over low-relief area]

Wise, S.M., 2000, Assessing the quality for hydrological applications of digital elevation models derived from contours: Hydrological Processes, v. 14, nos. 11-12, p. 1909-1929. [caveats general 
\& specific; elev. derivs., incl. TOPMODEL results, are broadly similar, diff. in detail; good biblio (see also http://www.shef.ac.uk/geography/staff/wise_stephen/dtm/dtm.htm]

Wise, S.M., 2000, GIS data modelling-lessons from the analysis of DTMs: International Journal of Geographical Information Science, v. 14, no. 4, p. 313-318. [many analysis problems arise fr modeling deficiencies in current GIS packages]

Wohl, E.E., Thompson, D.M., and Miller, A.J., 1999, Canyons with undulating walls: Geological Society of America Bulletin, v. 111, no. 7, p. 949-959. [l-shaped bedrock valleys; systematically varying wall width]

Wohl, E.E., 2000, Basin morphometry, in Mountain Rivers: Washington, D.C., American Geophysical Union, Water Resources Monograph 14, p. 44-49. [mountain \& lowland rivers differ in relief, valley slope, \& relief ratio, but not drainage density]

Wohl, E.E., and Merritt, D.M., 2001, Bedrock channel morphology: Geological Society of America Bulletin, v. 113, no. 9, p. 1205-1212. [9 params. on 41 reaches; substrate heterogen., slope \& Selby RMS best descriminants]

Woldenberg, M.J., 1971, The two-dimensional spatial organization of Clear Creek and Old Woman Creek, lowa, in Morisawa, M.E., ed., Quantitative geomorphology-some aspects and applications, Binghamton, NY, Annual Geomorphology Symposia Series, 2nd, October 15-16, Proceedings: p. 83-106. [hexagonal hierarchies at Hortonian orders 5-7 compared to human lung]

Woldenberg, 1972, Relations between Horton's laws and hydraulic geometry as applied to tidal networks: Cambridge, MA, Harvard University Graduate School of Design, Laboratory for computer graphics and spatial analysis, Harvard Papers in Theoretical Geography, 'Geography and the properties of surfaces' series, no. 45, p. 1-39. [no info]

Wolock, D.M., and McCabe, G.J., 2000, Differences in topographic characteristics computed from 100- and 1000-m resolution digital elevation model data: Hydrological Processes, v. 14, no. 6, p. 987-1002. [50 US locales, old 3' DEM; diffs in slope, basin A, \& wetness index due to discretization]

Womersley, J.R., and Hopkins, M.R., 1945, Suggestions concernant l'emploi du corrélogramme pour l'interprétation des enregistrements du fini de surface (on using the correlogram to interpret measurements of surface finish, in French): Journées des Etats de Surface, Editions de l'Office Professionnel Général de la Transformation des Métaux, Paris, p. 135-139. [first application of stochastic techniques to describe rough surfaces]

Wood, E.F., Sivapalan, Murugesu, Beven, K.J., and Band, L.E., 1988, Effects of spatial variability and scale with implications to hydrological modeling: Journal of Hydrology, v. 102, no. 1-4, p. 2947. [apply representative elementary area (REA) concept to hydrol.; ca. $1.0 \mathrm{~km} 2$; topog. infl.]

Wood, J.D., 1996, The geomorphological characterisation of digital elevation models: Geography Department, University of Leicester, UK, unpublished Ph.D. dissertation, 456 p., also <http://www.geog.le.ac.uk/jwo/research/dem_char/thesis/>. [comprehensive DEM-based terrain modeling; good biblio.]

Wood, J.D., 1998, LandSerf software (Version 1.6): University of Leicester, UK, Geography Dept., computer program for terrain surface DEM analysis. <http://www.geog.le.ac.uk/jwo/research/LandSerf/landserf16/doc/index.html>. [see his 1996 Ph.D. thesis]

Wood, J.D., 1998, Modelling the continuity of surface form using digital elevation models, in International Symposium on Spatial Data Handling, 8th, July 11-15, Vancouver, Canada, Proceedings: p. $725-736$, and 
http://www.geog.le.ac.uk/jwo/research/conferences/sdh98/index.html. [quadratic interpolation of continuous surfaces by semi-axes of conic sections]

Woodruff, J.F., 1963, Linear and areal properties of drainage basins as delimiting criteria (abs.): Annals of the Association of American Geographers, v. 53, no. 4, p. 631. [proposes paramaters for regional characterization]

Wooldridge, S.W., 1928, The 200-foot platform in the London Basin: Proceedings of the Geologists Association, v. 39, part 1, p. 1-26. [hypsometric curves fr lengths of intercepts along equidistant parallel lines]

Woronow, Alexander, and Mutch, Patricia, 1980, On the origin of Martian pedestal, lobate, and multilobate ejecta deposits, in Abstracts of papers submitted to the Lunar and Planetary Science Conference, 11th, March, Houston, TX, The Lunar and Planetary Institute: Lunar and Planetary Science XI, p. 1282-1284. [the old area/perimeter relation; fr Mandelbrot 1977 they get $\mathbf{P}^{1 / \mathbf{H}} / \mathbf{A}^{0.5}$ = K, where $\mathrm{H} \& \mathrm{~K}$ are constants, $\mathrm{H}$ the 'Hausdorff dimension' \& equiv. to 'lobateness' in Kargel 1986]

Wright, D.J., Goodchild, M.F., and Proctor, J.D., 1997, GIS-tool or science? Demystifying the persistent ambiguity of GIS as 'tool' versus 'science': Annals of the Association of American Geographers, v. 87, no. 2, p. 346-362. [philosoph. issues relevant to Terrain Modeling; see response by J. Pickles, p. 363-372]

Wu, Fan, 2000, Multi-scale automatic extraction of terrain structure line based on wavelet analysis (abs.): International Conference on Geographic Information Science 1st, GIScience 2000, Savannah, GA, 28-31 Oct., Abstracts, p. 389; http://www.giscience.org/GIScience2000/posters/090-Wu.pdf. [new way to extract ridges \& channels fr contours]

Wurm, A., 1936, Morphologische Analyse und Experiment Hangentwicklung, Einebnung, Piedmonttreppen: Zeitschrift für Geomorphologie, v. 9, p. 57-87. [series of experimental topo profiles evolved, systematically, w/ erosion]

\section{$\mathbf{X}$}

Xiao, Yanni, 1996, Topographic characterization for DEM error modelling: Vancouver, BC, University of British Columbia, unpublished Ph.D. dissertation, 447 p. [cluster analysis, DEMs, fractals, spatial variations]

Xiaohua, Zhu, and Jian, Wang, 1998, Fractal analysis applied to mountain ridges and faults-A case study of China (in Chinese with English abstract \& figure captions): Mountain Research (Shandi Yanjiu), v. 16, no. 2, p. 94-98. [D=1.63 (all China), but 1.35 in SW China; D of ridges \& faults related]

Xu, Jiandong, Qu, Guosheng, and Jacobi, R.D., 1999, Fractal and multifractal properties of the spatial distribution of natural fractures-analyses and applications: Acta Geologica Sinica, v. 73, no. 4, p. 477-487. [uses Cantor's dust theory; western NY sample; $D$ is scale dependent]

Xu, Wei, and Cumming, lan, 1999, A region-growing algorithm for InSAR phase unwrapping: IEEE Transactions on Geoscience and Remote Sensing, v. 37, no. 1, p. 124-134. [resulting DEM OK re. map heights; good but time-consuming] 
Yagi, Shintaro, and Takahashi, Yoshiaki, 1992, Three dimensional expression of the terrain using digital cartographic data: Bulletin of the Geographical Survey Institute, v. 37, p. 39-49. [reliefshading \& other output from 50-m and 250-m DEM's; no maps shown]

Yamada, Shuji, 1999, Mountain ordering-a method for classifying mountains based on their morphometry: Earth Surface Processes and Landforms, v. 24, no. 7, p. 653-660. [neo-orometry; defined by closed contours; params resemble Strahler's; number, area, \& height plot as power series]

Yamada, Shuji, 2001a, Classification and geomorphometry of Japanese mountains based on mountain ordering: Journal of Geography, v. 110, no. 1, p. 79-93. [applied neo-orometry fr $1 / 500 \mathrm{~K}$ maps; relief $=H / A^{0.5}$, where $H=$ height $\& A=$ area; rel. $R=\sum h_{i} / H$, where $h_{i}=$ height of enclosed lower-order mtn.; perimeter fractal D; all 3 are related in Japan]

Yamada, Shuji, 2001b, Evaluation of topographic naturalness of anthropogenically modified mountains: Geographical Review of Japan, v. 74A, no. 11, p. 643-657. [applied neo-orometry; 3 params. defined in 1999 \& 2001a differ for developed \& undeveloped $\mathrm{mtn}$ areas on $1 / 25 \mathrm{~K}$ maps]

Yang, M.-S., and Lee, K.T., 2001, Determination of probability distributions for Strahler stream lengths based on Poisson process and DEM: Hydrological Sciences Journal, v. 46, no, 5, p. 813824. [streams \& Strahler order extracted fr 40-m Taiwan DEM]

Yang, Xiaojun, and Hodler, Thomas, 2000, Visual and statistical comparisons of surface modeling techniques for point-based environmental data: Cartography and Geographic Information Science, v. 27, no. 2, p. 165-175. [DEM test; multiquadric RBF stat. best, min. curv. fastest, inverse-dist. poorest]

Yatsu, Eiju, 1955, On the longitudinal profile of the graded river: Transactions, American Geophysical Union, v. 36 , no. 4 , p. $655-663$. [7 of 9 river profiles consist of two exponential curves, not one]

Yeh, P.A., 1994, Fractal geometry and its implications for the Tatun volcanic area, Taiwan (in Chinese): Chung-Li, National Central University, Department of Applied Geology, M.Sc. thesis, 90 p. [used Clarke's triangular prism surface method for D]

Yemelyanov, O.G., 1984, Determination of slope gradient of a bottom using digital terrain model (in Russian): Geodesiya i Cartographiya, no. 11, p. 37-40. [no info; seafloor?]

Yin, K.L., and Yan, T.Z., 1988, Statistical prediction models for slope instability of metamorphosed rocks, in Bonnard, Christopher, ed., International Symposium on Landslides, 5th, 10-15 July, Lausanne, Proceedings: Rotterdam, Balkema, v. 2, p. 1269-1272. [4 classes for polygon units; elev, slope, relief, azimuth, \& lithology]

Yin, Z.-Y., and Wang, Xinhao, 1999, A cross-scale comparison of drainage basin characteristics derived from digital elevation models: Earth Surface Processes and Landforms, v. 24, no. 6, p. 557-562. [1/250K vs. $1 / 24 \mathrm{~K}$; elev. \& length params. OK, but not slope params.]

Yokoyama, Ryuzo, Shirasawa, Michio, and Kikuchi, Yu, 1999, Representation of topographical features by 'opennesses' (in Japanese with English abstract \& figure captions): Journal of the Japanese Society of Photogrammetry and Remote Sensing, v. 38, no. 4, p. 26-34. [imageprocessing; fits cone to each DEM elev.; brings out streams, ridges, textures]

Yokoyama, Ryuzo, Shirasawa, Michio, and Pike, R.J., 2002, Visualizing topography by openness-a new application of image processing to digital elevation models: Photogrammetric Engineering and Remote Sensing, v. 68 , no. 3, p. 257-265. [grey-scale images computed from DEM express degree of dominance or enclosure of locations on any irregular surface] 
Yoshida, Takeyoshi, Kanisawa, Satoshi, Yokoyama, Ryuzo, Shirasawa, Michio, and Ohguchi, Takeshi, 1999, Refinement of geological map by referring to high-resolution DEM and the derived digital maps-application to the study of Late Cenozoic caldera swarm in the NE Honshu arc, Japan (abs.): EOS, Transactions, American Geophysical Union, v. 80, no. 46, Supplement, p. F1088. [Yokoyama's 'openness' algorithm (50-m DEM) identifies circular features]

Yoshikawa, Torao, Kaizuka, Sohei, and Ota, Yoko, 1981, Relief energy of Japan (simplified from Economic Planning Agency 1969), in The Landforms of Japan: Tokyo, University of Tokyo Press, front endpaper. [4 intervals: >800, 400-799, 200-399, 0-199 m; recent use of term]

Young, Anthony, 1978, Slopes-1970-1975, ch. 5 in Embleton, Clifford, Brunsden, Denys, and Jones, D.K.C., eds., Geomorphology-Present Problems and Future Prospects: Oxford, The University Press, p. 73-83. [550 pubs. classified (but not listed); summary of slope mapping, profiles, other areas]

Young, R.A., and Mutchler, C.K., 1969, Effect of slope shape on erosion and runoff: Transactions of the American Society of Agricultural Engineers, v. 12, no. 2, p. 231-233, $239 . \quad$ [experiments on convex, concave (least soil loss), straight slopes; microrelief meas.]

Young, R.A., and Mutchler, C.K., 1969, Soil movement on irregular slopes: Water Resources Research, v. 5, no. 5, p. 1084-1089. [experiments on convex, concave (least soil loss), straight slopes; microrelief meas.]

Yu, Sidi, van Kreveld, Marc, and Snoeyink, Jack, 1996, Drainage queries in TINs-from local to global and back again, in Kraak, M.-J., Molenaar, Martien and Fendel, E.M., eds., International Symposium on Spatial Data Handling, 7th, Delft, Neth., Proceedings: Edinburgh, Taylor \& Francis, v. 2, p. 829-842; also 1996, 7th Symposium on Spatial Data Handling, Proceedings: p. 13A.113A.14. [preprocessing to facilitate queries; properties of drainage networks]

\section{$\mathbf{Z}$}

Zaitsev, V.M., Lavrova, V.S., and Chigirev, A.A., 1973, Derivation of contour maps using a stereomodel of a terrain and a computer (in Russian): Geodesiya i Cartographiya, no. 4, p. 48-53. [no info]

Zakrzewska, Barbara,1971, Nature of land form geography: Professional Geographer, v. 23, no. 4, p. 351-354. [core of LFG = "recognition of spatial land form problems \& analysis of their origin"]

Zâvoianu, Ion, 1972, The relationship between drainage density and stream frequency: Rev. Roum. Géol. Géophys., Géogr., Sér. Géogr., v. 16, no. 2, p. 167-174. [no info]

Zâvoianu, lon, 1974, Determination of the drainage net average slope in a given hydrographic basin: Rev. Roum. Géol. Géophys., Géogr., Sér. Géogr., v. 18, no. 2, p. 137-152. [no info]

Zebker, H.A., Amelung, Falk, and Jonsson, Sjonni, 2000, Remote sensing of volcano surface and internal processes using radar interferometry, in Mouginis-Mark, P.J., Crisp, J.A., and Fink, J.H., eds., Remote Sensing of Active Volcanism: Washington, DC, American Geophysical Union, Geophysical Monograph 116, p. 179-205. [DEMs for 16 edifices; much variance in quality]

Zeitler, P.K., Meltzer, A.S., Koons, P.O., Craw, David, Hallet, Bernard, Chamberlain, C.P., Kidd, W.S.F., Park, S.K., Seeber, Leonardo, Bishop, Michael, and Shroder, John, 2001, Erosion, Himalayan geodynamics, and the geomorphology of Metamorphism: GSA Today, v. 11, no. 1, p. 49. [elev \& shaded-relief maps; elev \& relief vs. downstream dist.; stream-profile analysis; erosion influences tectonics] 
Zhang, J.-t., Qiu, Yang, and Zheng, F.-y., 2000, Quantitative methods in landscape pattern analysis (in Chinese): Journal of Mountain Science, v. 18, no. 4, p. 346-352. [patch params. (elong., circ., etc.) of Turner, Forman, etc.]

Zhou, L., Kato, K., Umehara, N., and Miyake, Y., 1999, Nanometer scale island-type texture with controllable height and area ratio formed by ion beam etching on hard disk head sliders: Nanotechnology, v. 10, no. 4, p. 363-372. [nanoscopic 'landforms' created by design]

Zhu, Dehao, 1982, Evolution of peak cluster-depression in Guilin area and morphometric measurement (in Chinese): Carsologica Sinica, v. 1, p. 127-134. [claims to have identified evidence of 'dynamic equilibrium']

Zhu, Honglei, and Schneider, Kristin, 1999, Flat feature processes from triangulated irregular networks for hydrological modeling, in International Conference on GeoComputation, 4th, Fredericksburg VA, Mary Washington College, 25-28 July, GeoComputation 99: http://www.geovista.psu.edu/geocomp/geocomp99/Gc99/091/gc_091.htm. [algorithm removes level triangles, channels, \& ridges in TIN models]

Zhu, Honglei, Eastman, J.R., and Toledano, James, 2001, Triangulated irregular network optimization from contour data using bridge and tunnel edge removal: International Journal of Geographical Information Science, v. 15, no. 3, p. 271-286. [Delaunay triangulation \& parabolic interpolation of $B$ \& $T$ edges]

Zimmerman, B.B., 1972, Perspective view by computer: The Military Engineer, v. 64, no. 422 (November-December), p. 431 . [hidden- \& parallel-line plots of relief fr profiles or digitized contours]

Zobeck, T.M., and Popham, T.W., 2001, Cropping and tillage effects on soil roughness properties: Transactions of the American Society of Agricultural Engineers, v. 44, no. 6, p. 1527-1536. [5 cm DEM; random roughness, ridge height, \& cum. shelter angle distr.]

Zöppritz, Dr., 1882, comments (in German) in Günther (1882), p. $146 . \quad$ [the area/perimeter problem]

Zötl, Josef, 1951, Die Reliefenergie des Waldaist-Gebietes, in Landformung und Talentwicklung in Flußgebiet der Waldaist: Arbeiten a. d. Oberösterr. Musealvereins, v. 96, p. $36 . \quad$ [ca. 1/250K relative-relief map; 500-m samples; 6 relief intervals]

Zuber, M.T., and 14 others, 2000, Internal structure and early thermal evolution of Mars from Mars Global Surveyor topography and gravity Science, v. 287, no. 5459, p. 1788-1793. [crust thickness not correl. w/ topo. dichotomy, but is thin under lg. basins]

Zuber, M.T., and 20 others, 1998, Observations of the north polar region of Mars from the Mars Orbiter laser altimeter: Science, v. 282, no. 5396, p. 2053-2060. [2-km res. DEM; profiles of
[ craters \&; much new from MOLA]

Zuber, M.T., Smith, D.E., Phillips, R.J., Solomon, S.C., Banerdt, W.B., Neumann, G.A., and Aharonson, Oded, 1998, Shape of the northern hemisphere of Mars from the Mars Orbiter laser altimeter (MOLA): Geophysical Research Letters, v. 25, no. 24, p. 4393-4396. [18 profiles; elev. \& slope (low $E \approx$ low $S$ ); peaked hypsogram]

Zuber, M.T., and 11 others, 2000, The shape of 433 Eros from the NEAR-Shoemaker laser rangefinder: Science, v. 289 , no. 5487, p. 2097-2101. [detailed topo model of complex body from Near Earth Asteroid Rendezvous; elev. maps \& slope maps \& freq. distr.]

Zuchiewicz, Witold, 1995, Selected aspects of neotectonics of the Polish Carpathians: Folia Quaternaria (Krakow), no. 66, p. 145-204. [relative relief, stream orders \& long. profiles, var. param. ratios \& correls., etc.] 


\section{CORRECTIONS}

Abdul-Rahman, Alias, 1992, Triangular network in digital terrain relief modelling: ITC, Enschede, Netherlands, unpublished M.Sc. thesis, paging unknown. http://www.odyssey.maine.edu/gisweb/spatdb/egis/eg94038.html. [developed set of TIN-based DTM algorithms for PC environment]

Baldwin, Jonathan, Fisher, Peter, Wood, Joseph, and Langford, Mitchel, 1996, Modelling environmental cognition of the view with GIS: International Conference on Integrating GIS and Environmental Modeling, 3rd, January 21-25, Santa Fe NM, National Center for Geographic Information and Analysis, Proceedings (NCGIA CD-ROM); http://www.geog.le.ac.uk/jwo/research/dem_char/santafe/. [various considerations of viewshed analysis fr DEM]

Boyko, A.V., 1980, Metody i sredstva avtomatizatsii topograficheskikh s'yemka (Methods and Tools for Automated Topographic Surveys; in Russian): Nedra, Moscow, 222 p. [no info]

Brändli, Martin, 1996, Hierarchical models for the definition and extraction of terrain features, in Burrough, P.A., and Frank, A.U., eds., Geographic Objects with Indeterminate Boundaries, GISDATA series 2: London, Taylor and Francis, p. 257-270. [object-oriented top-down approach to peaks, pits, \& ridges; detail > at lower levels]

Brown, C.D., and Grimm, R.E., 1996, Floor subsidence and rebound of large Venus craters: Journal of Geophysical Research, v. 101, no. E11, p. 26,057-26,067. [no evidence for elastic rebound est. rigid lithosphere 10-15 km thick]

Chentsov, V.N., 1948, Morphometric indices on small-scale geomorphological maps (in Russian), in Grigoryev, A.A., and Markov, K.K., eds., Problems of Geomorphology, Transactions of the Institute of Geography, no. 39: Soviet Academic Press, Moscow, p. 291-306. [no info]

Chou, Yue-Hong, 1992, Slope-line detection in a vector-based GIS: Photogrammetric Engineering and Remote Sensing, v. 58, no. 2, p. 227-233. [derives slope lines (slow-lines normal to contours) from digitized contours, preferred to grid DEMs]

Clarke, K.C., Hoppen, Stacy, and Gaydos, L.J., 1996, Methods and techniques for rigorous calibration of a cellular automaton model of urban growth: International Conference on Integrating GIS and Environmental Modeling, 3rd, January 21-25, Santa Fe NM, National Center for Geographic Information and Analysis, Proceedings (NCGIA CD-ROM);

http://www.sbg.ac.at/geo/idrisi/gis_environmental_modeling/sf_papers/clarke_keith/clarkeetal.html. [groundslope gradient $\mathrm{fr}$ a DEM is one of the model constraints]

Coates, D.R., 1958, Quantitative geomorphology of small drainage basins of southern Indiana: Department of Geology, Columbia University, NY, Office of Naval Research, Geography Branch, Project NR 389-042, Technical Report no. 10, 67 p. (Ann Arbor, University Microfilms: publ. no. 17, MicA 56-2237). [10 3rd-order basins ea. in 6 areas; L, A, P, DD, circ., relief, slope \& stream gradient, hyps. integr. \& curves, etc.; strong contrast betw. USGS topo map \& field-derived topo map "... somewhat startling and the implications disturbing."]

De Sawal, Robert, 1996, Digital elevation data and GIS projects: International Conference on Integrating GIS and Environmental Modeling, 3rd, January 21-25, Santa Fe NM, National Center for Geographic Information and Analysis, Proceedings (NCGIA CD-ROM); http://www.ncgia.ucsb.edu/conf/SANTA_FE_CD-

$\mathrm{ROM} / \mathrm{sf}$ _papers/desawal_robert/usgspost.html. [good description of DEMs, their creation, flaws \& limitations]

Einstein, Albert, 1926, Die Ursache der Mäanderbildung der Flußläufe und des sogenannten Baerschen Gesetzes (Cause of the formation of meanders in river courses and of the so-called Baer's law): Naturwissenschaften, $v$. 14 , no. 11, p. 223-224. [the great man on a hydrogeomorphic problem]

Fels, J.E., and Matson, K.C., 1996, A cognitively-based approach for hydrogeomorphic land classification using digital terrain models: International Conference on Integrating GIS and Environmental Modeling, 3rd, January 21-25, Santa Fe NM, National Center for Geographic Information and Analysis, Proceedings (NCGIA CD-ROM); http://www.ncgia.ucsb.edu/conf/SANTA_FE_CD-ROM/sf_papers/fels_john/fels_and_matson.html. [land types of all NC fr 100-m DEM; land-type classifications for each of 6 major NC physiographic provinces] 
Florinsky, I.V., Grokhlina, T.I., and Mikhailova, N.L., 1995, LANDLORD 2.0-Software for the analysis and mapping of geometrical characteristics of relief (in Russian): Geodesiya i Cartographiya, no. 5, p. 46-51. [elev., slope, aspect, curv., area, topo. index, stream power index]

Gallant, J.C., and Hutchinson, M.F., 1996, Towards an understanding of landscape scale and structure: International Conference on Integrating GIS and Environmental Modeling, 3rd, January 21-25, Santa Fe NM, National Center for Geographic Information and Analysis, Proceedings (NCGIA CD-ROM); http://www.sbg.ac.at/geo/idrisi/gis_environmental_modeling/sf_papers/gallant_john/paper.html. [positive wavelet decomposition identifies topo features at diff. scales; feature shapes \& orientations may help char. landforms \& delimit contrasting regions]

Garbrecht, Jurgen, and Martz, L. W., 1997, TOPAZ-An Automated Digital Landscape Analysis Tool for Topographic Evaluation, Drainage Identification, Watershed Segmentation and Subcatchment Parameterization; TOPAZ User Manual: U.S. Department of Agriculture, Agricultural Research Service, Grazinglands Research Laboratory, El Reno, OK, ARS Publication no. GRL 97-4, 119 p. [DEM-to-watershed software; see also TOPAZ Installation Guide, ARS Publ. GRL 97-3, 12 p. \& TOPAZ Overview, ARS Publ. GRL 97-2, 21 p.]

Gauss, C.F., 1827, Disquisitiones generales circa superficies curvas (in Latin): Göttingen gelehrte Anziegen, no. 177 (5 Nov.), p. 1761-1768; abstract originally delivered before the Royal Society of Göttingen on 8 October 1827; reprinted 1873 in Carl Friedrich Gauss Werke: Königlichen Gessellschaft der Wissenschaften zu Göttingen 4, p. 217-258; translated 1902, as General investigations on curved surfaces of 1827 and 1825 , by Adam Hiltebeitel \& James Morehead: Princeton NJ, Princeton University Press, 127 p., \& reprinted 1965, Hewlett NY, Raven Press. [landmark paper; the result of 30 years of thinking on geodesy; seed of a century of subsequent work in differential geometry; origin of ground-surface classification by curvature \& treating topography as a random field; see Krcho, Shary, Dombrowski]

Gessler, P.E., McKenzie, Neil, and Hutchinson, Michael, 1996, Progress in soil-landscape modelling and spatial prediction of soil attributes for environmental models: International Conference on Integrating GIS and Environmental Modeling, 3rd, January 21-25, Santa Fe NM, National Center for Geographic Information and Analysis, Proceedings (NCGIA CD-ROM); http://www.ncgia.ucsb.edu/conf/SANTA_FE_CD-

ROM/sf_papers/gessler_paul/my_paper.html. [elev., gradient, \& topo index fr $20 \mathrm{~m}$ grid DEM fr 10-m contours @ $1: 25000]$

Hooke, R.LeB., and Rohrer, W.L., 1979, Geometry of alluvial fans-effects of discharge and sediment size: Earth Surface Processes, v. 4, no. 2, p. 147-166. [Markov-process models of slope \& rel. elev. compared w/ field meas.; power fncs. relate fan to basin properties]

Hoy, D.R., and Taylor, J.A., 1963, A descriptive classification of terrain (abs.): Annals of the Association of American Geographers, v. 53, no. 4, p. 598. [local relief, slope 'intensity' (contour density), topo. texture = basic elements; mapped Ohio]

Hutchinson, M.F., 1996, A locally adaptive approach to the interpolation of digital elevation models: International Conference on Integrating GIS and Environmental Modeling, 3rd, January 21-25, Santa Fe NM, National Center for Geographic Information and Analysis, Proceedings (NCGIA CD-ROM); http://edcdaac.usgs.gov/gtopo30/papers/local.html. [extends existing finite-difference approach to interpolation of DEMs]

Hutchinson, M.F., Nix, H.A., McMahon, J.P., and Ord, K.D., 1996, The development of a topographic and climate database for Africa: International Conference on Integrating GIS and Environmental Modeling, 3rd, January 2125, Santa Fe NM, National Center for Geographic Information and Analysis, Proceedings (NCGIA CD-ROM); http://www.sbg.ac.at/geo/idrisi/gis_environmental_modeling/sf_papers/hutchinson_michael_africa/africa.html. [digitized all 39 l/1M-scale air nav. charts; 109,000 non-zero pts. incl. spot elevs, important points on contours, streams]

Jackson, J.R., 1834, Hints on the subject of geographical arrangement and nomenclature: Journal of the Royal Geographical Society, v. 4, art. 4, p. 72-88 + colored diagram. [earliest (?) known topological ordering of streams (not cited in Cayley's two papers), but not definitive; lists basic geom. attributes of land form; plea for precise descr.]

Koristka, Karel (Carl), 1858, Studien über die Methoden und die Benützung hypsometrischer Arbeiten, nachgewiesen an den Niveauverhältnissen der Umgebungen von Prag. Ein neuer Beitrag zur Geodäsie und zur Orographie (... methods \& applic. of hypsom. work, detecting altitude relations around Prague. A new contrib. 
to geodesy \& orography; in German): Gotha, Justus Perthes, 107 p., 2 colored contour maps. [his most signif. morphometric work; reviewed in Petermanns Geogr. Mitt. 1858, v. 4, no. 12, p. 517; much on method; many heights; 1st mean-slope calculations (p. 96-102), for several valleys (formula later criticized as too complex for any but ridge-\&-valley terrain)]

Köthe, Rüdiger, 1996, Literary references for DTM, relief analysis, relief and soil, and relief and hydrology: http://uggg-pc-s1.uni-geog.gwdg.de/pg/sara/litdgm-e.htm. [link dead, 10/2002]

Laffan, Shawn, 1996, Rapid appraisal of groundwater discharge using fuzzy logic and topography: International Conference on Integrating GIS and Environmental Modeling, 3rd, January 21-25, Santa Fe NM, National Center for Geographic Information and Analysis, Proceedings (NCGIA CD-ROM); http://www.ncgia.ucsb.edu/conf/SANTA_FE_CD-ROM/sf_papers/laffan_shawn/s_fetxt4.html. [minimalist broad-area model; $10 \mathrm{~m}$ cell size, index of slope curvature]

Levitt, D.A., and Sandwell, D.T., 1996, Modal depth anomalies from multibeam bathymetry-is there a South Pacific superswell?: Earth and Planetary Science Letters, v. 139, nos. 1-2, p. 1-16. robust depths fr modeseeking procedure (ETOPO5 data poor) reveal concentrations of deep flat surfaces]

Maidment, D.R., 1996, GIS and hydrologic modeling-An assessment of progress: International Conference on Integrating GIS and Environmental Modeling, 3rd, January 21-25, Santa Fe NM, National Center for Geographic Information and Analysis, Proceedings (NCGIA CD-ROM): http://www.ce.utexas.edu/prof/maidment/gishydro/meetings/santafe/santafe.htm. [incl. processing DEMs \& standardized approach to watershed delineation]

Matson, K.C., and Fels, J.E., 1996, Approaches to automated water table mapping: International Conference on Integrating GIS and Environmental Modeling, 3rd, January 21-25, Santa Fe NM, National Center for Geographic Information and Analysis, Proceedings (NCGIA CD-ROM); http://www.ncgia.ucsb.edu/conf/SANTA_FE_CDROM/sf_papers/matson_kris/santa-fe.2.html. ['Iandscape-classification' approach uses land types determined fr DEMs]

Mayer, Larry, 1990, Introduction to Quantitative Geomorphology_an exercise manual: Englewood Cliffs, NJ, Prentice Hall, 380 p.; online electronic edition, 1995, at http://tgl.geology.muohio.edu/gbook/gresources.html, link dead 10/2001. ['a quantitative foundation for the study of geomorphological processes']

McCullagh, M.J., 1996, Quality, visualization, and use of terrain models in physical system modelling: International Conference on Integrating GIS and Environmental Modeling, 3rd, January 21-25, Santa Fe NM, National Center for Geographic Information and Analysis, Proceedings (NCGIA CD-ROM); http://www.sbg.ac.at/geo/idrisi/gis_environmental_modeling/sf_papers/mccullagh_michael/mjmpaper.html. [GIS pkgs. overtaken in flexibility \& photorealism by true 3-D modelling systems]

Miller, D.R., and Morrice, J.G., 1996, Assessing uncertainty in catchment boundary delimitation: International Conference on Integrating GIS and Environmental Modeling, 3rd, January 21-25, Santa Fe NM, National Center for Geographic Information and Analysis, Proceedings (NCGIA CD-ROM); http://www.ncgia.ucsb.edu/conf/SANTA_FE_CD-ROM/sf_papers/miller1_david/miller_paper1.html. [derivation, reliability, stability assessment, national UK database]

Mitas, Lubos, Mitásová, Helena, Brown, W.M., and Astley, Mark, 1996, Interacting fields approach for evolving spatial phenomena-Application to erosion simulation for optimized land use: International Conference on Integrating GIS and Environmental Modeling, 3rd, January 21-25, Santa Fe NM, National Center for Geographic Information and Analysis, Proceedings (NCGIA CD-ROM); http://www2.gis.uiuc.edu:2280/modviz/viz/SF.final/mitas.html. [elev., slope gradient \& curvature combined with non-topo spatial info.]

Mitásová, Helena, and Hofierka, Jaroslav, 1993, Interpolation by regularized spline with tension-II, application to terrain modeling and surface geometric analysis: Mathematical Geology, v. 25, no. 6, p. 657-669. [better eqns for profile, plan \& tangent curvatures by descr.-geom. combining grid \& vector appraches; real terrain examples; added to GRASS pkg.]

Müller-Wohlfeil, D.-I., Lahmer, W., Krysanova, V., and Becker, A, 1996, Topography-based hydrological modelling in the Elbe drainage basin: International Conference on Integrating GIS and Environmental Modeling, 3rd, January 21-25, Santa Fe NM, National Center for Geographic Information and Analysis, Proceedings (NCGIA 
CD-ROM); http://www.ncgia.ucsb.edu/conf/SANTA_FE_CD-ROM/sf_papers/mueller_dirk/dmwpaper.html. [apply TOPMODEL \& WET, models based on the topographic-index concept]

Nowicki, A.L., 1961, Topographic lunar mapping at the Army Map Service: Washington, D.C., September, AMS Technical Report no. 37, 20 p. [How AMS' 1:5M stereo 1-km-contour maps of the Moon were made fr 18961907 Paris Observatory photo plates]

Ollier, C.D., 1967, Geomorphic indications of contour map inaccuracy: Cartography (Canberra), v. 6, p. 121-124. [more caveats]

Péguy, Ch.P., 1942, Une analyse morphométrique de la zone intra-alpine des Alpes françaises Méridionales (in French): Bull. Assoc. Géogr. Franç., B, no. 144-145, p. 22-24. [rock hardness controls ave. slope but not elev.]

Penck, Albrecht, 1894, Chapter 2, Morphographie und Morphometrie, in Morphologie der Erdoberfläche (in German), Stuttgart, J. Engelhorn, v. 1, p. 33-95. [state-of-art review, possibly the most important until Neuenschwander 1944; subheads incl. the forms their parts ('form-elements', 'unit-forms', 'landscapes', \& 'areas') \& representation, mean height \& slope (formula on p. 47), processing \& surface area, mean height \& fall \& height processing of surface boundaries \& area of boundary profiles, boundary processing \& spatial arrangement, volume calc., surface \& distance calc., types \& classes of forms; mean slope formula; scaledependent lengths of Istrian coast; etc.; book review by Charles Lapworth 1895, Geogr. Jour. 5/6, p. 575-81]

Pitty, A.F., 1969, A scheme for hillslope analysis, I. Initial considerations and calculations: University of Hull (UK), Occasional Papers in Geography, no. 9, 76 p. [fr. Ph.D. thesis; background, slope char., meas. methods, diagrams \& calcs.; favors field over map data]

Ritter, Carl, 1852, Einleitung zur allgemeinen vergleichenden Geographie, und Abhandlungen zur Begründung einer mehr wissenschaftlichen Behandlung der Erdkunde (Introduction to general comparative geography, \& papers establishing a more scientific treatment of geography, in German): Berlin, Sammlung der Abhandlungen Ritters (Ritter's Collected Papers), Berlin, G. Reimer, 246 p. [among earliest morphometry; re-release of 'Einleitung...' \& 'Allgemeine Vorbemerkungen über die festen Formen der Erdrinde' (both from intro to v. 1 of the Erdkunde, 1817) \& 5 lectures at the Kgl. Akad. d. Wissenschaften, Berlin, 1826, 1828, 1833, 1836, 1850, published previously in Abhandlung d. kgl. Akad. ... (hist.-phil. KI.). A rather free English transl. by Wm.L. Gage, ed., 1861 (1863?), Geographical Studies: Boston (also N.Y.?), Gould \& Lincoln, 356 p. (see pp. 142, $150,212-240$, etc.). French transl. by Danielle Nicolas-Obadia, 1974, Introduction á la géographie générale comparée, Cahiers de géographie de Besançon, no 22; Annales littéraires de l'Université de Besançon, 155: Paris, Les Belles Lettres, 253 p.]

Sonklar, C.E. von I., 1873, Orometrischer Theil (Orometric section) p. 173-192, in Allgemeine Orographie, die Lehre von den Relief-Formen der Erdoberfläche (General orography, the science of relief forms of the earth's surface, in German): Vienna, W. Braumüller, 254 p. [one of the landmarks in 19th C. orometry (a term he evidently coined, possibly in his 1860 book on the Oetzthaler Gebirgsgruppe), these few pages summarize his major contribution, 12 morphometric measures-later criticized (by Penck, Hettner, \& others) as too many \& not suffiently linked to geomorphic process; was the 2 nd to propose a mean-slope formula, but too subjective; book shows influence by Ritter's concept of 'comparative geography']

U.S. Defense Mapping Agency, 1992, Digital chart of the World (Edition 1, July; for use with the Disk Operating System), Fairfax, VA; 2nd, updated edition (1998) at http://www.nima.mil/publications/vmap0.html. [DCW data base-1500 megabytes of vector data organized in 17 thematic layers, including all 1000-foot elevation contours-Ed. 1 on 4 compact disks, VPFVIEW software, and users manual paged by section]

U.S. Geological Survey, 1994, GCIP Reference Data Set (GREDS): U.S. Geological Survey Open-file Report 94388; one CD-ROM; http://water.usgs.gov/GIS/browse/gcip.HTML. [for 48 U.S. states, incl. 500-m DEM, geology, land use, streams, reservoirs, ave. ann. runoff \& precip., hydrologic units, etc.]

Vakhtin, B., 1930, On the determination of the mathematical characteristics of relief (in Russian): Geodezist (Moscow), no. 2-3, p. 7-16. [no info]

Verdin, Kristine, and Jenson, S.K., 1996, Development of continental scale digital elevation models and extraction of hydrographic features: International Conference on Integrating GIS and Environmental Modeling, 3rd, January 21-25, Santa Fe NM, National Center for Geographic Information and Analysis, Proceedings 
(NCGIA CD-ROM); http://edcdaac.usgs.gov/gtopo30/papers/santafe3.html. $\quad$ [30 arc-sec. (90 m) global DEM to replace ETOPO5 (5 arc-min, 10km) data]

Walker, Hoyt, Leone, J.M. Jr., and Kim, Jinwon, 1996, The effects of elevation data representation on mesoscale atmospheric model simulations: International Conference on Integrating GIS and Environmental Modeling, 3rd, January 21-25, Santa Fe NM, National Center for Geographic Information and Analysis, Proceedings (NCGIA CD-ROM); http://www.ncgia.ucsb.edu/conf/SANTA_FE_CD-ROM/sf_papers/walker_hoyt/gismod96.html. [signif. effects fr DEM resampling or smoothing]

Woldenberg, M.J., 1967, Concepts and applications—spatial order, Part II, in Warntz, William, and Woldenberg, M.J., Geography and the properties of surfaces series, paper no. 1: Harvard Papers in Theoretical Geography, Cambridge, MA, Harvard University, Graduate School of Design, Laboratory for Computer Graphics and Spatial Analysis, for Geography Branch, Office of Naval Research, Project NR 389-147, Technical Report, p. 95-173, 185-189. [6 sections on allometric growth, networks, surface topology, fluvial systems]

Zakharov, S.A., 1940, Importance of slope aspect and gradient for soil and vegetation distribution in the Great(er) Caucasus (in Russian): Journal Botanique de I'URSS, v. 25, no. 4-5, 378-405. [see Zingg 1940 for presumably similar material] 